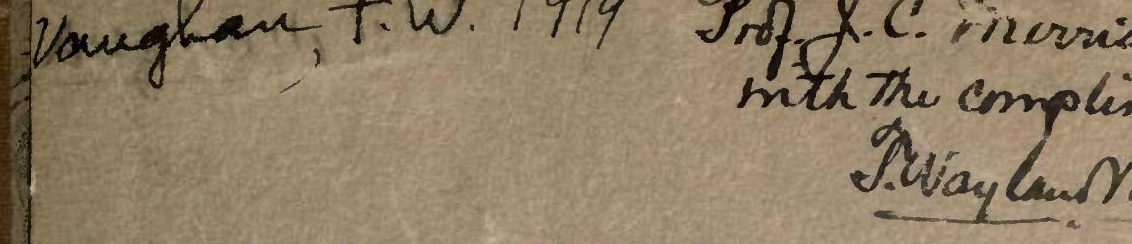

CONTRIBUTIONS TO THE GEOLOGY AND PALEON OF THE WEST INDIES

Prepared under the Direction of THOMAS WAYLAND VAUGHAN

UC-NRLF ||||||||||||||||||||||||||||||||||||||||||||

कर 9 b6?

Mattiow Library

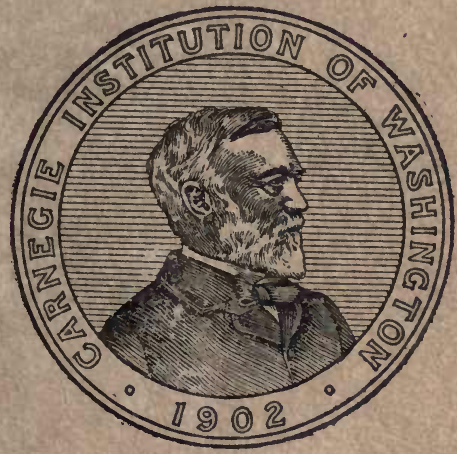

Published by the Carnegre Institution of Washingt WASHINGTON, 1919 



\title{
CONTRIBUTIONS TO THE GEOLOGY AND PALEONTOLOGY OF THE WEST INDIES
}

\author{
Prepared under the Direction of \\ THOMAS WAYLAND VAUGHAN
}

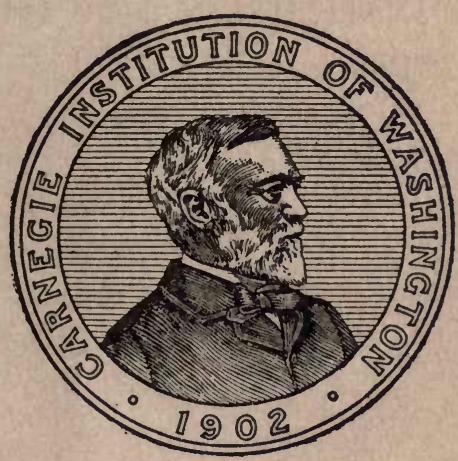

PUblished by the Carnegie Institution of Washington WASHINGTON, 1919 


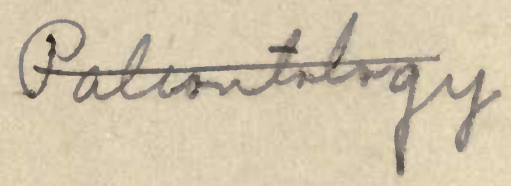

CARNEGIE INSTITUTION OF WASHINGTON

Publication No. 291

Copies of this Boris.

were first issued

OCT 171919

PRESS OF GIBSON BROTHERS, INC.

WASHINGTON, D. C. 


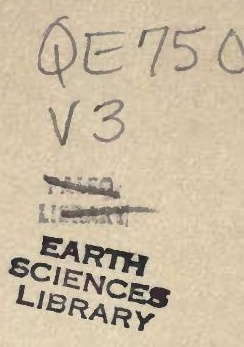

\section{CONTENTS.}

Introduction by Thomas Wayland Vaughan..................... PAGE

Tertiary Calcareous Algæ from the Islands of Saint Bartholomew, Antigua, and Anguilla, by Marshall A. Howe............................ 9

Fossil Foraminifera from the West Indies, by Joseph Augustine Cushman......... 21

Fossil Bryozoa from the West Indies, by Ferdinand Canu and R. S. Bassler........ 73

Tertiary Mollusks from the Leeward Islands and Cuba, by Charles Wythe Cooke... 103

West Indian Tertiary Decapod Crustaceans, by Mary J. Rathbun............... 157 


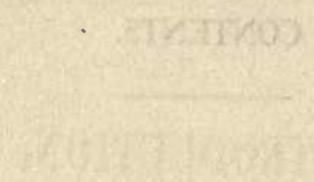

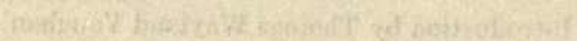

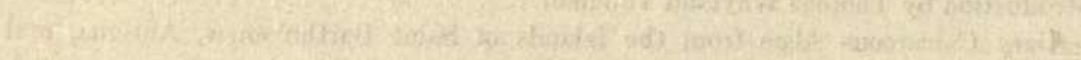
200

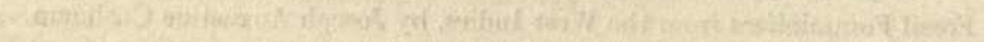

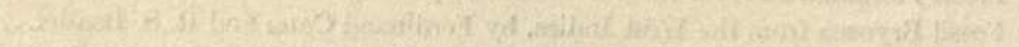

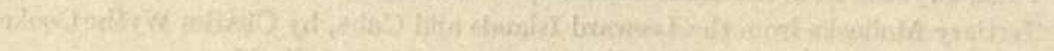

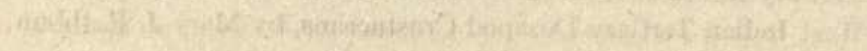




\section{INTRODUCTION.}

By Thomas Wayland Vaughan. 


\section{forpowitog?h/1}

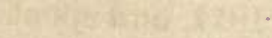

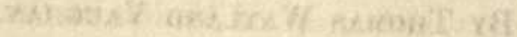

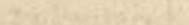

-

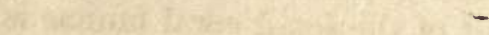

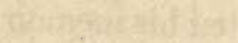

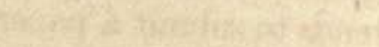

$x+2=0$

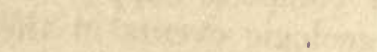




\section{INTRODUCTION.}

The series of memoirs contained in the present volume has resulted from a minor grant made to me by the Carnegie Institution of Washington in the autumn of 1913 for the study of the stratigraphic geology and of the fossil corals and associated organisms in several of the smaller West Indian Islands and from the authority given me by the Director of the United States Geological Survey to make the investigations as a part of my official work. The objects of these studies were stated in my first progress report, ${ }^{1}$ as follows:

(1) To study the stratigraphic geology of the islands, and to make paleontologic collections with special reference to the stratigraphic occurrence of the fossils, so as to establish a proper basis for correlating the geologic formations in the islands with those of the southeastern United States and Panama.

(2) To make additional collections of fossil corals in order to present a more comprehensive and exact account of the successive coral faunas antecedent to the living fauna than was possible with the material already available, and thus trace the history of the development of the coral faunas through Tertiary time up to and including the Recent fauna.

(3) To study the physiography of the islands in order to get a basis for making deductions as to how the conditions were brought about under which the living coral reefs were formed.

I left Washington during the latter part of January 1914, and spent the month of February and most of March in the islands of Antigua, Saint Bartholomew, Anguilla, Saint Martin, and Saint Christopher. While engaged in field work I received a great deal of help from the officials of the respective islands and will particularly mention Sir $\mathrm{H}$. Hesketh Bell, then governor of the Leeward Islands, and T. L. Roxborough, then administrator of Saint Christopher. Rather large collections of fossils resulted from my efforts and they have now been completely or almost completely described and illustrated. Five papers are herewith presented; my own account of the fossil coral faunas is almost finished; Dr. Robert T. Jackson has nearly completed his memoir on the fossil echinoids; and Dr. Paul Bartsch intends to submit a paper on the fossil and living land Mollusca of the Leeward and Virgin Islands.

The accompanying papers and those nearly complete supply the foundation for the correlation of the different geologic events in the West Indies, and they will be followed by descriptions of local geologic details and an account of the general development of the region, in correlation with the geologic events that were taking place in the southeastern United States and Central America. Most of the manuscript relating to local details and geologic interpretation is already written and might have been complete had the entrance of the United States into the World War not necessitated diversion to other duties.

\footnotetext{
${ }^{1}$ Carnegie Institution of Washington Year Book No. 13, p. 358, 1915.
} 
Since my return from the West Indies in 1914, I have either based several papers on the results of my work there or have utilized those results in connection with other papers. The following is the list:

\section{Papers by Thomas Wayland Vaughan containing results of his West Indian Expedition in 1914.}

The platforms of barrier coral reefs. Am. Geog. Soc. Bull., vol. 46, pp. 426-429, 1914.

Study of the stratigraphic geology and of the fossil corals and associated organisms in several of the smaller West Indian Islands [progress report]. Carnegie Inst. Wash. Year Book No. 13, 1914, pp. 358-360, 1915.

Coral reefs and reef corals of the southeastern United States, their geologic history and their significance. Abstract, Science, new ser., vol. 41, pp. 508-509, Apr. 2, 1915; Geol. Soc. America Bull., vol. 26, pp. 58-60, 1915.

Introductory remarks to symposium on the factors producing changes in position of strand line during Pleistocene and post-Pleistocene. Washington Acad. Sci. Jour., vol. 5, pp. 444-445, June 19, 1915.

[Résumé of the present status of geologic correlation of the Cretaceous and Tertiary formations of the Antilles.] Washington Acad. Sci. Jour., vol. 5, p. 489, July 19, 1915.

Memorandum on the geology of the ground waters of the island of Antigua, British West Indies. West Indian Bull., vol. 14, No. $4,4 \frac{1}{2} \mathrm{pp}$. and map, 1915. Imperial Department of Agriculture for the West Indies.

Present status of the investigation of the origin of barrier coral reefs. Am. Jour. Sci., vol. 41, pp. 131-135, January 1916.

Some littoral and sublittoral physiographic features of the Virgin and Northern Leeward Islands and their bearing on the coral-reef problem. Washington Acad. Sci. Jour., vol. 6, No. 3, February 4, 1916; Abstract, Geol. Soc. America Bull., vol. 27, No. 1, pp. 41-45, March 1916.

Study of the stratigraphic geology and of the fossil corals and associated organisms in several of the smaller West Indian Islands [progress report]. Carnegie Inst. Wash. Year Book No. 14, pp. 368-373, 1916.

The corals and coral reefs of the Gulf of Mexico and the Caribbean Sea. Read before Am. Assoc. Adv. Sci., in cooperation with the Pan-American Congress. Abstract, Science, new ser., vol. 43, pp. 250-251, February 18, 1916.

Study of the stratigraphic geology and of the fossil corals and associated organisms in several of the smaller West Indian Islands [progress report]. Carnegie Inst. Wash. Year Book No. 15, p. 359, 1917.

The reef-coral fauna of Carrizo Creek, San Diego County, California, and its significance. U. S. Geol. Survey, Prof. Paper 98-T, pp. 355-386, pls. 92-102, text-figs. 43-46, 1917. Abstract, Geol. Soc. America Bull., vol. 28, No. 1, p. 200, March 1917.

Study of the stratigraphic geology and of the fossil corals and associated organisms in several of the smaller West Indian Islands [progress report]. Carnegie Inst. Wash. Year Book No. 16, p. 319, 1918.

Correlation of the Tertiary formations of the southeastern United States, Central America, and the West Indies. Washington Acad. Sci. Jour., vol. 8, pp. 268-276, May 1918.

Fossil corals from Central America, Cuba, and Porto Rico, with an account of the American Tertiary, Pleistocene, and Recent coral reefs. U. S. Nat. Mus. Bull. 103, pp. 189-523, pls. 68-152, 22 text-figs., 1919.

The biologic character and geologic correlation of the sedimentary formations of Panama, in their relation to the geologic history of Central America and the West Indies. U. S. Nat. Mus. Bull. 103, pp. 547-612, 1919.

Corals and the formation of coral reefs. Smithsonian Inst. Ann. Rept., 1917, pp. 189-238 37 pls., 16 text-figs, 1919.

I wish here to record my thanks to President Woodward, of the Carnegie Institution of Washington, and to Dr. George Otis Smith, the Director, and Dr. David White, the Chief Geologist, of the United States Geological Survey, for the support they have given these investigations. It also gives me pleasure to express my deep appreciation of the efforts of my scientific colleagues in making proper studies of the rather large collections that I was so fortunate as to assemble. 
I.

TERTIARY CALCAREOUS ALGAE FROM THE ISLANDS OF ST. BARTHOLOMEW, ANTIGUA, AND ANGUILLA.

By Marshall A. Howe.

With six plates. 


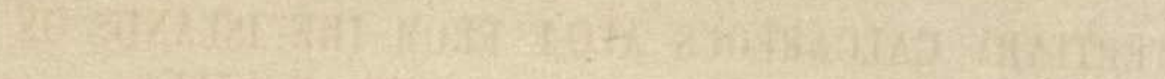

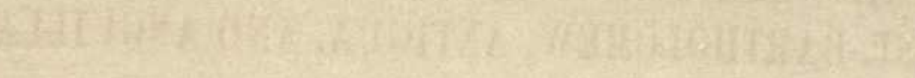

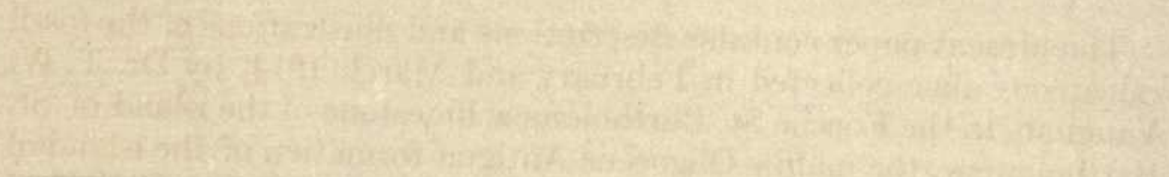

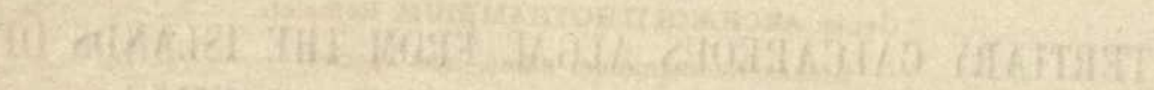

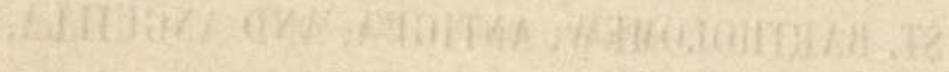

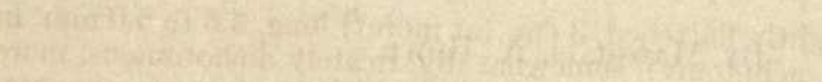

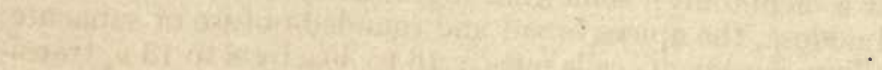

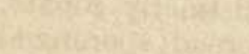

-

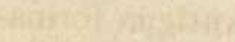

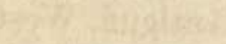

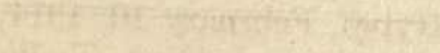




\section{TERTIARY CALCAREOUS ALGE FROM THE ISLANDS OF ST. BARTHOLOMEW, ANTIGUA, AND ANGUILLA.}

By Marshall A. Howe.

The present paper contains descriptions and illustrations of the fossil calcareous algæ collected in February and March 1914, by Dr. T. W. Vaughan, in the Eocene St. Bartholomew limestone of the island of St. Bartholomew, the middle Oligocene Antigua formation of the island of Antigua, and the upper Oligocene Anguilla formation of the island of Anguilla.

\section{ALGÆ.}

\section{ClasS RHODOPHYCEAE.}

\section{Family CORALLINACEEE.}

\section{Genus ARCHEOLITHOTHAMNIUM Rothpletz.}

\section{Archæolithothamnium affine, new species.}

(Plate 4, Figure 1; Plate 5.)

The following is a description of this species:

Thallus terete or slightly flattened, $3 \mathrm{~cm}$. (or more?) long, 3.5 to $6.0 \mathrm{~mm}$. in diameter ( $8 \mathrm{~mm}$. at a dichotomy), somewhat divaricately dichotomous, more or less sinuous and nodose, the apices broad and rounded-obtuse or subacute; medullary hypothallium zonate, its cells mostly 16 to $30 \mu$ by 8 to $13 \mu$, transition to the perithallium gradual; perithallium more or less distinctly zonate, its cells 8 to $26 \mu$ by 8 to $13 \mu$, often about $14 \mu$ high and $12 \mu$ broad; sporangial sori becoming overgrown and embedded, the sporangial cavities elliptic-oval in longitudinal section, 55 to $78 \mu$ high and 27 to $46 \mu$ broad.

In the Carlisle marl pit (Oligocene, lower part of Antigua formation), on slope just above the level of the central plain, Antigua, West Indies, T. W. Vaughan, station No. 6873 (type), February 10, 1914; also at McKinnon's (Oligocene, Antigua formation), Antigua, T. W. Vaughan, No. 6888, March 1914. The latter of the two specimens is partially embedded, but the former (plate 4) is free. The structure in both is well preserved and ground sections exhibit their structure nearly as well as would be the case with living or recent material. $A$. affine appears to be closely related to the living $A$. siboga A. Web. and Fosl. ${ }^{1}$ of the region of the Sulu Archipelago, Borneo, and Celebes, from which it seems to differ in its larger cells, especially of the perithallium, which are 8 to $26 \mu$ by 8 to $13 \mu$, while in $A$. sibogoe they were described by Weber and Foslie as 5 to $12 \mu$ by 5 to $8 \mu$; in microtome

${ }_{1}^{1}$ Foslie, M., Three new Lithothamnia, Kgl. Norsk. Vidensk. Selsk. Skr., 1901, No. 1, p. 3; Webervan Bosse, A., and M. Foslie, The Corallinaceæ of the Siboga Expedition, Siboga Exped. Monog. 61, 1904, p. 41, pl. vir. 
sections made from decalcified material of authentic $A$. sibog $x$ furnished by Madam Weber, the perithallic cells often seem larger than these measurements would indicate, yet the cells are rarely more than $13 \mu$ long, while in our fossil plant most of the cells, in radio-vertical section, are more than $13 \mu$ long. Moreover, our sections of $A$. affine are mostly oblique and our measurements may not do full justice to the length of its cells. Numerous "minute square and oblique intermediate cells * * * 2 to $4 \mu$ in diameter," ascribed to A. sibogoe, we have not observed in A. affine.

The sporangial cavities are numerous and they appear in thallus sections sometimes in rows of 30 or 40 . Some of the embedded sori are near the surface and others are so close to the medulla that twothirds of the radius of the thallus-branch would lie external to them.

Archooolithothamnium curasavicum (K. Mart.) Foslie, ${ }^{1}$ a Cretaceous fossil from the island of Curaçao, is described and figured as having a crustaceous rather than a terete fruticose thallus. Martin's figure 23, however, looks a little like a cross-section through an eccentric terete thallus, but it is described as a longitudinal section and is probably designed to represent the coralline as attached to and partially inclosing some foreign object, an explanation that gains support from the author's description of the plant.

Of the hitherto described fossil species of Archoeolithothamnium, A. affine is probably best compared with $A$. turonicum (Rothpl.) Fosl., ${ }^{2}$ from the Turonian of Le Beausset, Dép. Var, France, but it is coarser, having branches 3.5 to $6 \mathrm{~mm}$. instead of $3 \mathrm{~mm}$. in diameter.

\section{Genus LITHOTHAMNIUM Philippi.}

Lithothamnium concretum, new species.

(Plate 1, Figure 2; Plate 2.)

The following is a description of this species:

Thallus forming irregularly hemispheric, subglobose, or ellipsoidal, solid or more or less hollow, concretionary masses, mostly 2 to $5 \mathrm{~cm}$. in diameter, the surface exhibiting a few rounded, slightly pronounced irregular knobs or lobes, these usually 5 to $15 \mathrm{~mm}$. broad and 5 to $8 \mathrm{~mm}$. high; medulla irregularly oblong in section, 5 to $15 \mathrm{~mm}$. broad, becoming hollow on exposure; weathered fractures of thallus showing numerous tortuous or irregularly plicate more or less concentric lamellæ, these mostly 0.5 to $1.0 \mathrm{~mm}$. thick, at length somewhat elevated or solute; cells of primary medullary hypothallia 8 to $13 \mu$ broad; secondary hypothallia infrequent, 100 to $170 \mu$ thick, scarcely "coaxial," their cells 14 to $18 \mu$ (rarely $26 \mu$ ) by 8 to $13 \mu$; perithallium conspicuously, sharply, narrowly, and irregularly zonate, its larger cells 10 to $15 \mu$ by 8 to $12 \mu$, its smaller $8 \mu$ by $6 \mu$ or subquadrate ( 8 to $11 \mu$ square) or occasionally broader

1 Lithothamnium curasavicum K. Mart. Bericht uber eine Reise nach Niederlandisch WestIndien und darauf gegründete Studien. II. Geologie, 1888, p. 26, pl. II, figs. 22 to 25.

${ }^{2}$ Lithothamnium turonicum Rothpl. Zeitschr. deutsch. Geol. Ges., vol. 43, 1891, pl. xvI, figs. 9, 13. [Plate is wrongly numbered $\mathrm{xv}$.]

Not well shown in longitudinal view in the sections thus far made. 
than high; tetrasporangial conceptacles numerous, becoming embedded, oblong or elliptic-oblong in radio-vertical section, 380 to $770 \mu$ in maximum width, 122 to $168 \mu$ in height; roof of conceptacle flat or very slightly convex, its cells 6 to $10 \mu$ (rarely $13 \mu$ ) high, only slightly higher than broad.

Hodges Bluff, lower bed (Oligocene, middle part of Antigua formation), Antigua, West Indies, T. W. Vaughan, No. $6862,{ }^{1}$ February 6 , 1914.

Lithothamnium concretum may deserve comparison with Lithothamnium suganum Rothpl., ${ }^{2}$ from the Tertiary ("Scio-Schichten") of Val Sugana, near Borgo in the Austrian Tyrol, but its perithallic cells appear to be often larger ( 8 to $15 \mu$ by 6 to $12 \mu$ as compared with 9 to $12 \mu$ by 7 to $9 \mu$ ) and its conceptacles also are much larger (380 to $770 \mu$ by 122 to $168 \mu$ vs. $250 \mu$ by $100 \mu$ ). We have seen no published figure or description of external form of $L$. suganum. Possibly Lithothamnium torulosum Gümbel ${ }^{3}$ is a nearer relative. This was first found near Traunstein, in Bavaria, and was originally attributed to the Oligocene, but Rothpletz ${ }^{4}$ reports it from other localities in Europe and thinks it belongs primarily to the Eocene. This forms rounded, slightly lobed or warted masses (specimen figured is about $3 \mathrm{~cm}$. by $1.5 \mathrm{~cm}$., with elevations about $5 \mathrm{~mm}$. in diameter). Gümbel gives cell measurements as $8 \mu$ by $6 \mu$, but Rothpletz makes the perithallic cells 7 to $12 \mu$ by 7 to $9 \mu$, from which it would appear that those of $L$. concretum are a little larger. Gümbel did not describe or figure conceptacles, but Rothpletz states that they are $400 \mu$ by $150 \mu$, which probably means that they are considerably smaller than in $L$. concretum.

The plant is not closely related to any species of Lithothamnium now living in the West Indian region, so far as is known to the writer. In fact, it is not obvious with what living or recent species it may best be compared.

Since the above was written, the writer has received (May 1919) an important paper by Madame Paul Lemoine on some fossil coralline algæ of Martinique, ${ }^{5}$ the distribution of which paper has possibly been somewhat delayed by war conditions. In this treatise several new species are described, one of which, Lithothamnium lacroixi Lemoine, based upon thin sections of pieces of calcareous rock thrown up by the volcano Mount Pelée and of uncertain geologic age, evidently shows a close affinity to $L$. concretum. It would, however, seem to be a more crustaceous and less massive plant than $L$. concretum, with cells of the

${ }^{1}$ The sections shown in the micrographs, which may be considered the type material in a narrow sense, came from a fragment that has been labeled $a a ; b$ is another alga, both from station 6862 .

2 Zeitschr. deutsch. Geol. Ges., vol. 43, 1891, p. 319, plate xvIr, fig. 4. Compare also Capeder, G., Malpighia, vol. 14, 1900, pp. 176, 177, plate vi, fig. 3.

3 Abhandl. mat.-phys. Cl. k. bayer. Akad. Wiss., vol. 11, abth. 1, 1871, p. 40, plate Ir, figs. $6 a, 6 b$.

- Zeitschr. deutsch. Geol. Ges., vol. 43, 1891, p. 318.

- Contribution à l'étude des Corallinacées fossiles. Bull. Soc. Géol. de France, sér. 4, vol. 17 1917, pp. 233-279. (Date of distribution, Dec. 1918; fide auct. in litt.) 
perithallium in more manifest vertical rows; in radio-vertical sections of $L$. concretum it is the horizontal or concentric alignment of the perithallic cells that is the regular and obvious thing (see plate 2), while in $L$. lacroixi the vertical or radial alignment would often appear to be more manifest.

\section{Genus LITHOPHYLLUM Philippi.}

Lithophyllum homogeneum, new species.

(Plate 1, Figure 1; Plate 3.)

The following is a description of this species:

Thallus massive or coarsely subfrutescent, forming concrescent masses 7 to $18 \mathrm{~cm}$. (or more?) broad, the main branches or axes subterete, subtrigonous or irregularly flattened, 5 to $20 \mathrm{~mm}$. in diameter; weathered fractures showing rather indistinct irregularly concentric lamellæ, these 'ess than $1 \mathrm{~mm}$. thick; cells of both hypothallium and perithallium in regular layers; secondary hypothallia of rare occurrence; cells of hypothallium 20 to $26 \mu$ by 8 to $13 \mu$; perithallium for the most part obscurely, or now and then distinctly, zonate, rather homogeneous in structure, its cells mostly 13 to $20 \mu$ by 10 to $13 \mu$, occasionally reaching length of $25 \mu$; conceptacles unknown.

Embedded in limestone (upper Eocene or lower Oligocene), above head of Governor's Bay, St. Bartholomew, T. W. Vaughan, station No. 6923, February 22, 1914.

In its massive, coarsely subfrutescent habit, Lithophyllum homogeneum may have borne some resemblance to the recent $L$. antillarum Foslie and Howe, ${ }^{1}$ but it is very different in structure, having a general ground substance of much larger cells and failing to show (in section) the short rows of enlarged cells which characterize Foslie's genus or subgenus Porolithon.

Among the fossil forms, a weathered section of one of the coarser branches of Lithophyllum homogeneum may bear a slight superficial resemblance to Lithothamnium concretum M. A. Howe (Antigua, Vaughan, No. 6862), but a prepared section shows a much more homogeneous, less zonate structure, with larger cells. Conceptacles have not been identified with certainty, but the vegetative structure suggests that its place is with Lithophyllum rather than with Lithothamnium. A possible relative is the plant from Oligocene strata at "Astrup bei Osnabrück," Germany, described and figured by Gümbel ${ }^{2}$ as Lithothamnium tuberosum and afterwards described by Rothpletz. ${ }^{3}$ The specimens of the latter were apparently free, while Lithophyllum homogeneum is embedded, so that it is somewhat difficult to compare the two as to external form, but $L$. homogeneum is probably a more frutescent and less crustaceous plant, with branches, or some of them,

1 Bull. Torrey Bot. Club, vol. 33, 1906, p. 579, fig. 2 and plates 25, 26.

${ }^{2}$ Abhandl. mat.-phys. Cl. k. bayer. Akad. Wiss., vol. 11 , abth. 1,1871 , p. 39 , plate I, figs. $5 a, 5 b, 5 c$.

Zeitschr. deutsch. Geol. Ges., vol. 43, 1891, p. 317, 318. 
coarser (5 to $20 \mathrm{~mm}$. in diameter vs. 8 to $10 \mathrm{~mm}$.). Rothpletz refers to the thickening of the thallus by a repeated "Ueberwucherung" of the hypothallium - a character that is scarcely noticeable in L. homogeneum, so far as is shown by the sections thus far obtained. No conceptacles were observed in Lithothamnium tuberosum, so the genus remains in doubt. The cell measurements as given by Gümbel are somewhat less than those obtained from our Lithophyllum homogeneum, while those given by Rothpletz from an "Originalstück" are somewhat greater. Rothpletz often finds Gümbel's cell measurements too small and he intimates that Gümbel had made some error in calibrating his eye-piece micrometer.

\section{Lithophyllum (?) molare, new species.}

(Plate 4, Figures 2 to 4 .)

The following is a description of this species:

Thallus masses 2 to $4 \mathrm{~cm}$. (and more?) in height, composed of more or less fused or anastomosing flattened branches, these 4 to $10 \mathrm{~mm}$. broad, 3 to $5 \mathrm{~mm}$. thick, molariform or subspatulate, the obtuse, retuse, or sparingly corrugated apices sometimes free for 5 to $10 \mathrm{~mm}$.; perithallium and medullary hypothallium not clearly differentiated, cells of both in regular layers; cells of medullary hypothallium 20 to $26 \mu$ by 10 to $13 \mu$; perithallium rather obscurely or now and then distinctly zonate, showing occasionally 1 to 4 layers of short cells alternating with a subequal number of layers of long cells, the cells subquadrate in section, the larger 15 to $18 \mu$ in diameter, often $16 \mu$ high and $13 \mu$ broad, the smaller about $8 \mu$ in diameter, often broader than high; conceptacles unknown.

From bluff (Oligocene, middle of Antigua formation) on north side of Willoughby Bay, Antigua, T. W. Vaughan, $b$ from station No. 6881. Another and evidently different coralline alga ( $a$ from station No. 6881 ), with subterete, intricately intertangled branches 1.5 to $3 \mathrm{~mm}$. in diameter, was collected at the same time and place, but the two apparently do not occur intermingled.

In general form and habit, Lithophyllum (?) molare resembles certain broad-branched forms of the recent Lithophyllum doedaleum Fosl. \& Howe, ${ }^{1}$ originally described from Porto Rico, and also, in a less degree, the recent Lithophyllum platyphyllum Fosl., ${ }^{2}$ from St. Martin, of the Leeward Islands. It seems, however, to differ from both of these in the thicker, more distinctly zonate perithallium and the relatively shorter and (in section) more quadrate cells. In both $L$. docdaleum and L. platyphyllum, the larger cells of the inner perithallium or outer medullary hypothallium (the two tissue-systems commonly blend

\footnotetext{
${ }^{1}$ Bull. N. Y. Bot. Garden, vol. 4, 1906, p. 133, plates 83, 84, and 85, f. 1.

2 Goniolithon platyphyllum Fosl., Kgl. Norske Vidensk. Selsk. Skr. 1898, No. 6, p. 13; Lithophyllum platyphyllum Fosl., Kgl. Norske Vidensk. Selsk. Skr. 1900, No. 5, p. 18. As was subsequently recognized by Foslie, this species has nothing to do with $L$. craspedium and $L$. africanum, between which it was placed in his "Revised Systematical Survey."
} 
together very gradually) are usually about $26 \mu$ long and twice as long as broad; in $L$. (?) molare the corresponding cells are about 15 to $18 \mu$ long and scarcely longer than broad. Our best sections of $L$. (?) molare are, however, somewhat oblique and may not do full justice to the length of the cells. In $L$. platyphyllum the much flattened branches are thinner and less massive, being only 1.25 to $2 \mathrm{~mm}$. thick.

\title{
Lithoporella melobesioides (Foslie) Foslie.
}

(Plate 6.)

\begin{abstract}
Lithoporella melobesioides (Foslie) Foslie, Kgl. Norske Vidensk. Selsk. Skr., 1909, No. 2, p. 59. Mastophora melobesioides Foslie, Kgl. Norske Vidensk. Selsk. Aarsber. for 1902, p. 24, 1903; Siboga Exped. Monog. 61, 1904, p. 75-77, figs. 30-32.

Mastophora (Lithoporella) melobesioides Foslie, Kgl. Norske Vidensk. Selsk. Skr., No. 7, p. 19, 1908; op. cit., No. 2, p. 52, 1909.

Mastophora (Lithoporella) atlantica Foslie, Kgl. Norske Vidensk. Selsk. Skr., No. 2, p. 27, 1906.

Lithoporella atlantica Foslie, Kgl. Norske Vidensk. Selsk. Skr., No. 2, p. 59, 1909.

Mastophora (Lithoporella) conjuncta Foslie, Kgl. Norske Vidensk. Selsk. Skr., No. 6, p. 30, 1907.

Lithoporella conjuncta Foslie, Kgl. Norske Vidensk. Selsk. Skr., No. 2, p. 59, 1909.
\end{abstract}

The following is a description of the fossil West Indian forms of this species:

Monostromatic thalli occurring singly, or 2 to 8 of them irregularly, loosely, or now and then rather compactly superposed; cells (19) 23 to $57 \mu$ high and 13 to $39 \mu$ wide, 1 to 3 (mostly 1.5 to 2 ) times as high as wide, in a vertical section appearing for the most part distinctly rounded at the angles and occasionally suborbicular and submoniliform; conceptacles unknown.

On and intercalated among other calcareous algæ incrusting a fossil millepore (?), in "top bed" (upper Oligocene), Crocus Bay, Anguilla, T. W. Vaughan, station No. 6967 (plate 6, fig. 2); with millepore (?), Crocus Bay Hill (upper Oligocene), roadside, descent to Crocus Bay from valley, Anguilla, T. W. Vaughan, station No. 6893 ; intermingled with other calcareous algæ from bluff (Oligocene, middle of Antigua formation) on north side of Willoughby Bay, Antigua, T. W. Vaughan, station No. 6881; and intercalated with Lithophyllum homogeneum in limestone (upper Eocene or lower Oligocene) from above head of Governor's Bay, St. Bartholomew, T. W. Vaughan, No. 6923 (plate 6, fig. 1), February 22, 1914.

The description, as given above, is drawn from the fossil West Indian specimens cited, but it would require only very slight changes in the cell measurements to make it include all of the forms, recent and fossil, described by Foslie under the names cited above. On first meeting with this plant in one of the Anguilla specimens from station No. 6967 , it was our impression that it might be considered specifically distinct from all of the forms described by Foslie in its shorter cells (19 to $42 \mu$ in the specimen cited), but the subsequent discovery of the other specimens showed both a great variety of forms and sizes of cells 
in a single individual and also a complete intergrading with the cell characters of Lithoporella melobesioides, L. atlantica, and L. conjuncta, as described by Foslie. Form and size of the vegetative cells and size of the conceptacles are the characters relied upon by Foslie to distinguish his proposed species in this genus. The following comparison will, we think, illustrate the difficulty of maintaining species based on these distinctions; the numbers in parenthesis denote occasional extremes:

Cell dimensions of species, acc. to Foslie:
L. melobesioides......................
L. melobesioides.......................
L. melobesioides f. varians................ 1908, 40-54 $\mu \times(18) 25-43 \mu$.
L. melobesioides f. typica................
L. melobesioides f. varians.................. 1909, (30) $40-60$ (85) $\mu \times(18) 25-43(54) \mu$.
L. atlantica................................. (32) $36-55(60) \mu \times 18-36(40) \mu$.

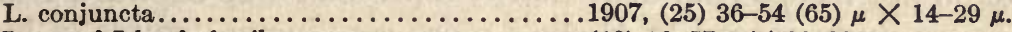
Leeward Islands fossils.................. (19) $23-57 \mu \times 13-39 \mu$.
Conceptacles of species acc. to Foslie:
L. melobesioides...................... 1903, 600-1000 $\mu$.
L. melobesioides...................... 1904, $800-1000 \mu$.
L. atlantica........................
L. conjuncta........................

From the above showing it would appear that, unless future researches should reveal conceptacles of a distinctive character, there is little or no ground for considering the Leeward Islands fossil specifically different from recent forms already described.

Lithoporella melobesioides was originally described as a living species from the Maldives, but has since been reported also as a fossil from New Guinea. ${ }^{1} L$. atlantica and $L$. conjuncta, both recent species, were described from St. Jan in the Danish West Indies and the west coast of Africa, respectively. All of these were originally proposed under the generic name Mastophora, but in the typical species of Mastophora the thallus consists of several layers of thick-walled cells, which are very slightly or not at all calcified. Foslie's final establishment ${ }^{2}$ of a genus Lithoporella to receive the monostromatic calcified forms that he had previously referred to Mastophora seems justified, though Madame Lemoine, in a recent paper, ${ }^{3}$ prefers to consider Lithoporella a subgenus of Melobesia.

Lithoporella pacifica (Heydrich) Foslie, ${ }^{4}$ first described as a recent plant of the Hawaiian Islands, is said by Foslie to have cells that are 32 to 80 (110) $\mu$ by 7 to $12 \mu$, which would make them considerably longer and narrower than those of any of the forms referred to above. Moreover, there are discrepancies of some importance between the descriptions of this plant as given by Heydrich and as given by Foslie,

\footnotetext{
${ }^{1}$ Siboga Exped. Monog. 61, 1904, p. 75-77, fig. 32.

2 Kgl. Norske Vidensk. Selsk. Skr. 1909, No. 2, p. 58.

In Børgesen, Dansk Bot. Ark., vol. 3, 1917, No. 1, p. 174.

- Melobesia pacifica Heydrich, Bot. Jahrb. vol. 28, 1901, p. 529; Mastophora (Lithoporella) pacifica Foslie, Kgl. Norske Vidensk. Selsk. 1909, No. 2, p. 53; Lithoporella pacifica Foslie, loc. cit., 59.
} 
though both professedly examined the same material, preserved in the Muséum d'Histoire Naturelle of Paris. Foslie at first considered the plant to belong to the Squamariaceæ. ${ }^{1}$ In case that anyone should find adequate grounds for combining Lithoporella pacifica with the forms brought together above, it may be remarked that the name pacifica would appear to enjoy priority rights over melobesioides. However, there is a still earlier name of probable applicability that must be considered if a "broad" view of species is to be accepted and if the fossil and recent forms are to be looked upon as representing a single species. This is the Lithothamnium tenuiseptum of Capeder, ${ }^{2}$ from the Pliocene of Monte Mario (near Rome?), Italy. Capeder's figure of the microscopic structure is rather diagrammatic and sketchy and we do not feel so confident that it represents our Leeward Islands fossil as we do in regard to Foslie's more convincing figures of his $L$. melobesioides. Capeder describes the cells as $60 \mu$ by $18 \mu$ and figures them as 3 times as high as broad, a proportion that is of only occasional occurrence in $L$. melobesioides as we know it. Conceptacles are described as $404 \mu$ by $202 \mu$, but if two cavities shown in his detailed figure are the supposed conceptacles, and if the relations of the surrounding cells are correctly represented, it may be suspected that these cavities represent holes of boring animals or other fortuitous lacunæ rather than conceptacles.

The West Indian fossils that we are referring to Lithoporella melobesioides, as is usual with the species of Foslie's subgenus Eulithoporella, are very commonly overgrown by other calcareous algæ, sometimes lying in alternating layers with such algæ, and are not always visible in a surface view.

The collections made in the Leeward Islands by Dr. Vaughan include several representatives of the Lithothamniex in addition to the 5 species described and discussed in the foregoing report, but we have not felt justified in giving them names, owing to the limited quantity or unsatisfactory preservation of the material or to lack of success in obtaining sufficiently instructive sections.

Deserving special mention among these specimens left undetermined is one, $a$, from station No. 6881, bluff (Oligocene) on north side of Willoughby Bay, Antigua, which has intertangled subterete branches 1.5 to $3.0 \mathrm{~mm}$. in diameter.

A specimen from station No. 6854, Rifle Butts (Oligocene), Antigua, shows one or more species of thin crustaceous Lithothamnieæ closely adherent to old millepores or corals. In general habit these resemble the recent Goniolithon solubile Foslie and Howe, which now incrusts dead corals and millepores throughout the West Indian region.

1 Kgl. Norske Vidensk. Selsk. Skr. 1901, No. 2, p. 19.

2 Malpighia, vol. 14, 1900, p. 181, plate vr, figs, $17 a, 17 b$. 
Specimen $a$ from station No. 6856, from Friars' Hill (Oligocene), Antigua, includes an apparently sterile Lithothamnium which seems to be very close to Lithothamnium isthmi M. A. Howe from the Oligocene of the Panama Canal Zone (MacDonald and Vaughan, No. 6021) and may be identical with it.

Specimen $b$, from station No. 6862, Hodges Bluff, lower bed (Oligocene), Antigua, consists chiefly of one of the Lithothamnieæ with rather elongate subterete branches 2 to $4 \mathrm{~mm}$. in diameter. In general habit and in structure it seems to bear considerable resemblance to certain forms of the recent Goniolithon strictum Fosl. of the West Indian region.

A specimen from station No. 6967, top bed (upper Oligocene), Crocus Bay, Anguilla, shows chiefly a millepore or other calcareous animal, but incrusting it, in addition to the Lithoporella melobesioides mentioned above, is a Lithothamnium that appears to be related to the recent $L$. syntrophicum Fosl. of the West Indian region, but probably differing in having a thallus that is not always thin and crustaceous, but occasionally lifted into short knobs or wartlike excrescences. 


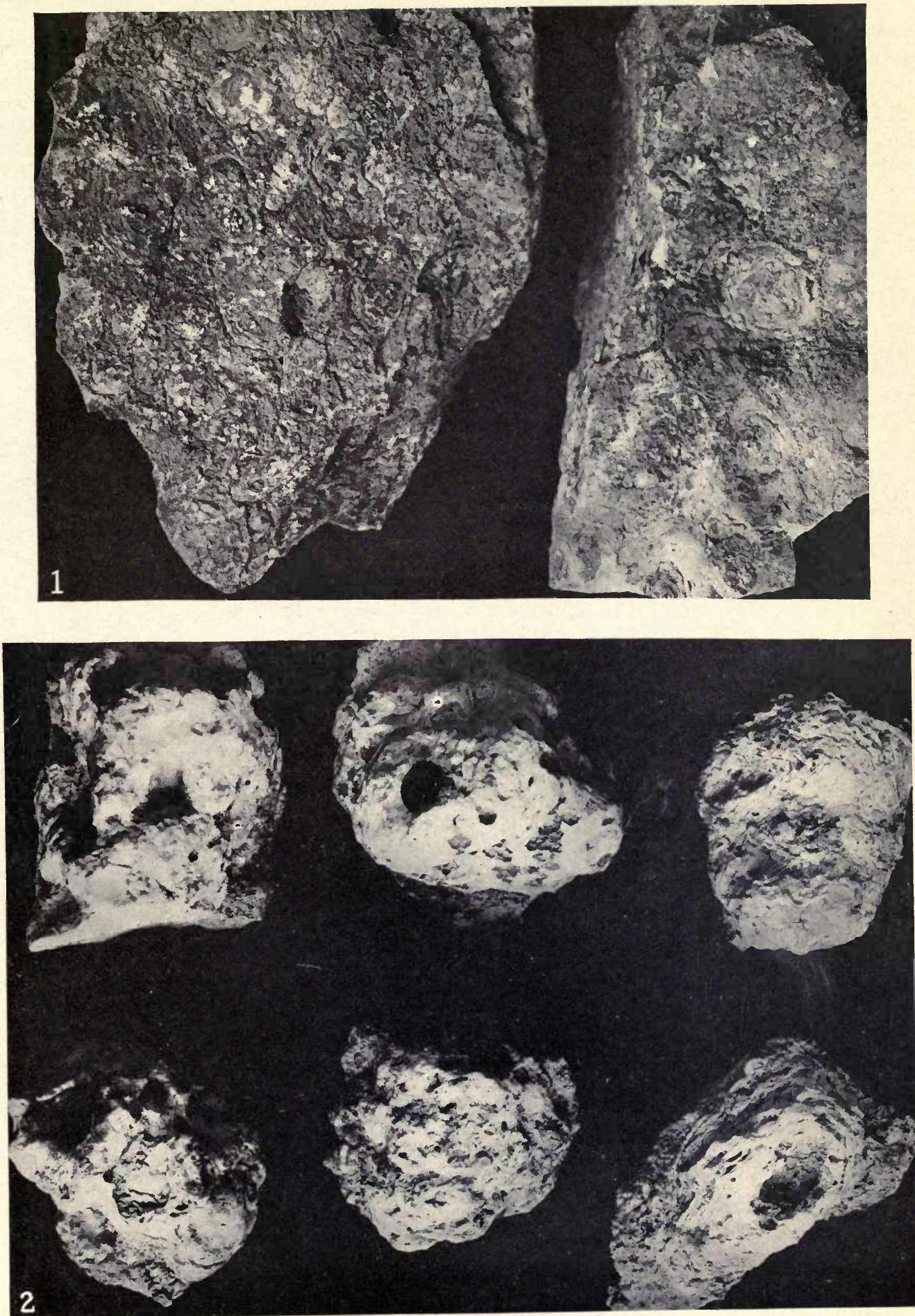

FIG. 1.-Lithophyllum homogeneum, n. sp. Photograph of all of the embedded material, from above head of Governor's Bay, St. Bartholomew (T. W. Vaughan, Station No. 6923). Natural size.

FIG. 2.-Lithothamnium concretum, n. sp.. Photograph of nearly free specimens from Hodge's Bluff, Antigua (T. W. Vaughan, Station No. 6862). Natural size. 


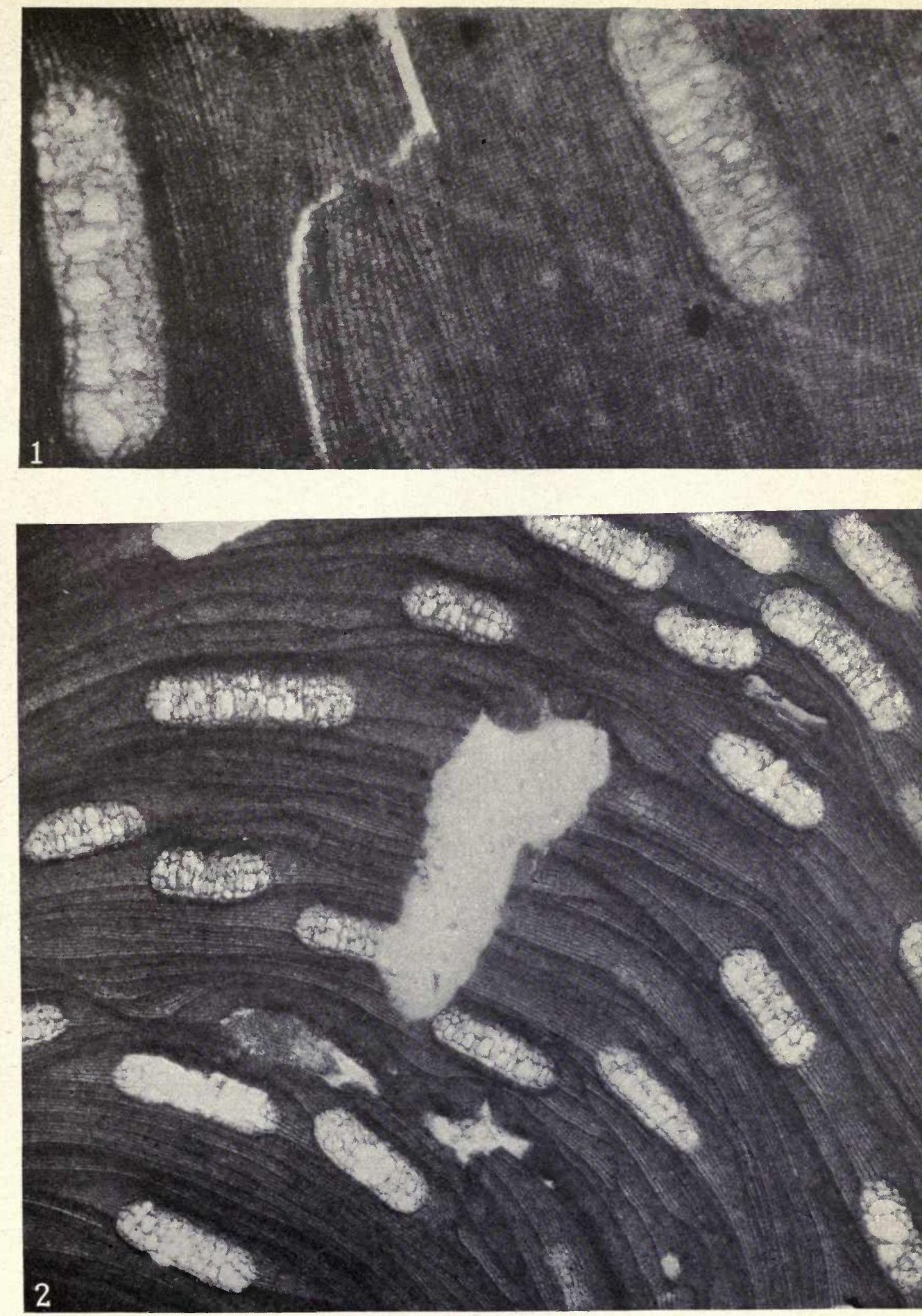

Lithothamnium concretum, n. sp.

FIg. 1.-Photograph of radio-vertical section (from same specimen as fig. 2), showing cell structure, tetrasporic conceptacles, etc., enlarged 100 diameters. The surface of the thallus is toward the right.

FIG. 2.-Photograph of radio-vertical section, showing zonations, tetrasporic conceptacles, etc., enlarged 42 diameters. 



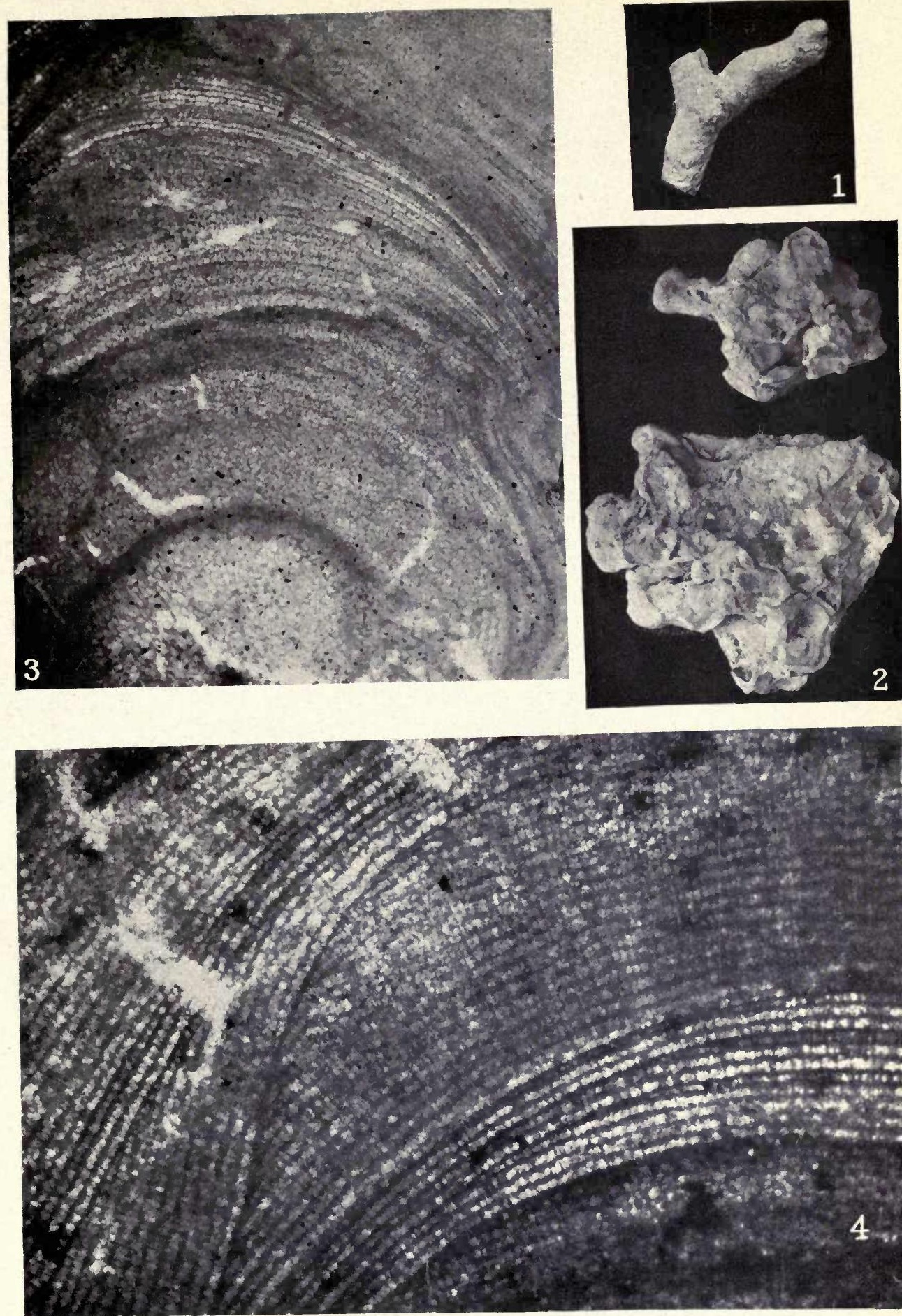

Fig. 1.-Archocolithothamnium affine, n. sp. Photograph of the free type specimen, from Carlisle marl pit. Antigua (T. W. Vaughan, Station No. 6873); slightly enlarged $\left.\left({ }_{9}^{1}\right)^{1}\right)$.

FIGs, 2 to 4.-Lithophyllum (?) molare, n. sp. (2) Photograph of all of material from north side of Willoughby Bay, Antigua (T. W. Vaughan, $b$ from Station No. 6881); slightly enlarged $\left(\frac{5}{4}\right)$. (3) Photograph of part of an obliquely transverse section of a large branch, enlarged 44 diameters. (4) Photograph of part of a radio-longitudinal section of same branch, showing perithallic cells, etc., enlarged 100 diameters. 

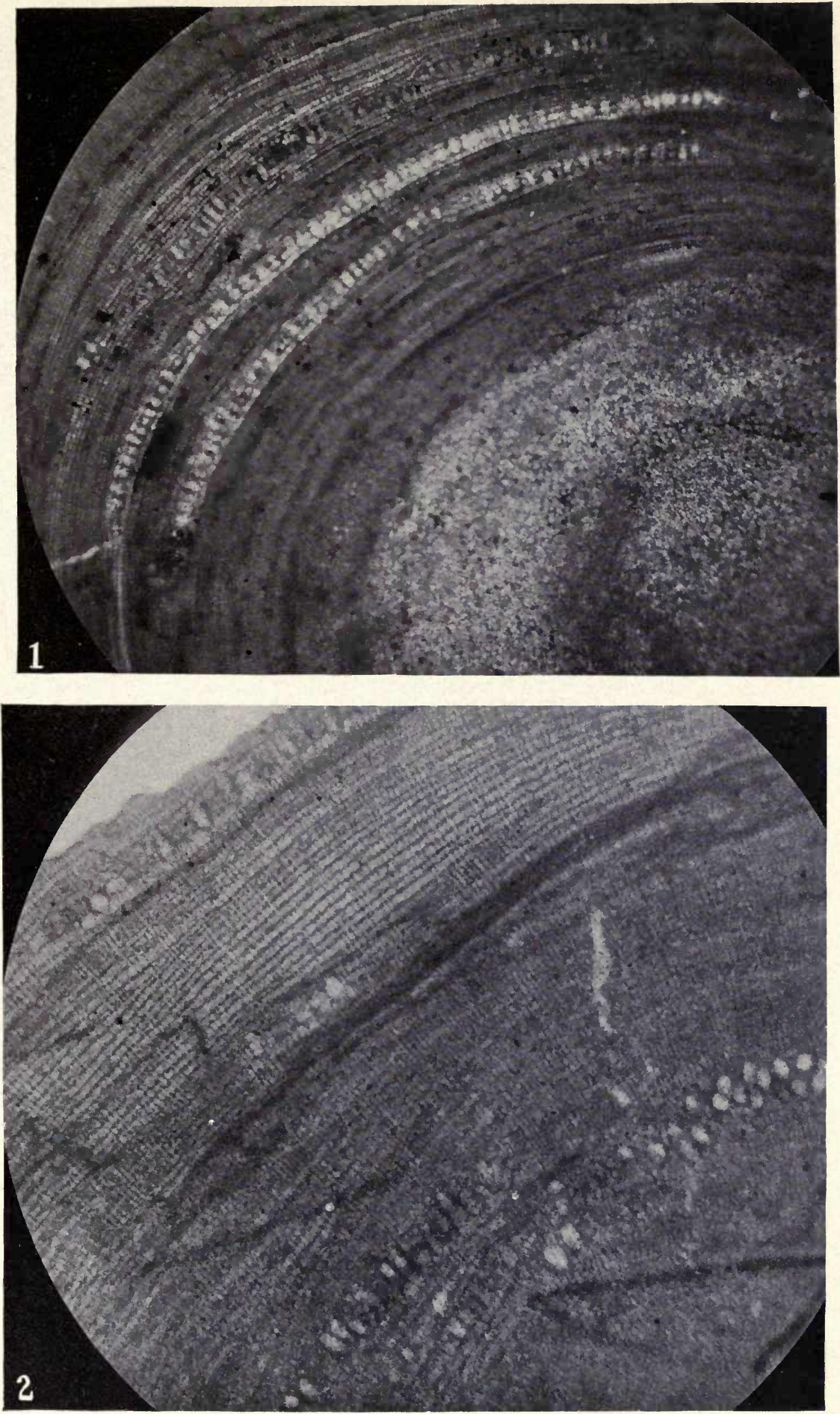

Archoolithothamnium affine n. sp.

FIG. 1.-Photograph of part of an obliquely transverse section (Antigua, T. W. Vaughan, Station No. 6873), from branch at left as shown in fig. 1, plate 4), enlarged 44 diameters.

Fig. 2.-Photograph of a part of an obliquely transverse section (Antigua, T. W. Vaughan, Station No. 6888), enlarged 72 diameters. 


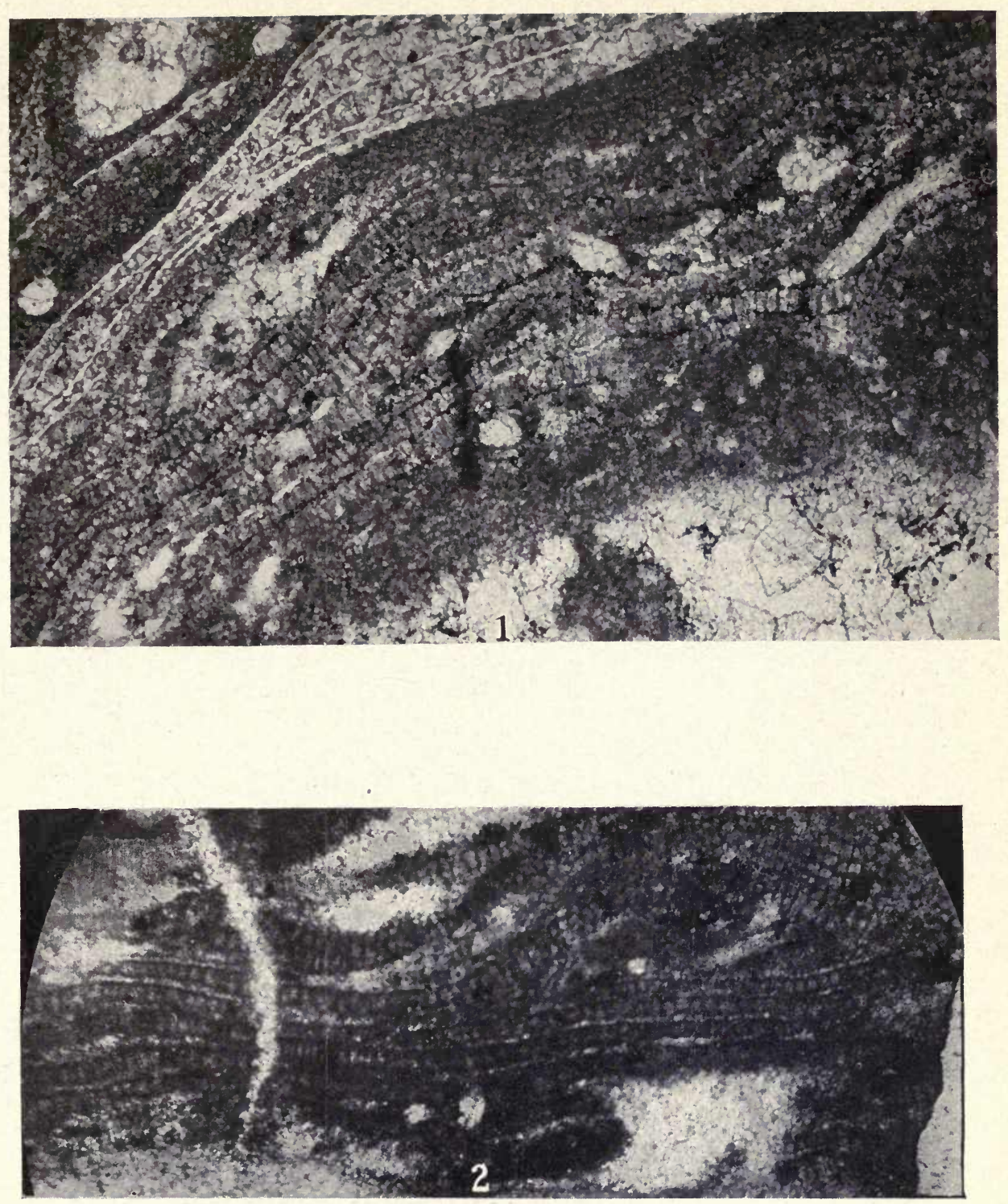

Lithoporella melobesioides (Foslie) Foslie.

FIG. 1.-Photograph showing irregularly superposed layers (near middle of field, appearing as rows of cells in section), Station No. 6923, St. Bartholomew, T. W. Vaughan. The cells in section are here mostly 1.5 to 3 times as high as wide. Enlarged 72 diameters.

FIG. 2.-Photograph of other specimens in section, likewise intercalated with various foreign organisms, from Anguilla, T. W. Vaughan, Station No. 6967. The cells in section here are mostly 1 to 2 times as high as wide. Enlarged 72 diameters. 

II.

\title{
FOSSIL FORAMINIFERA FROM THE WEST INDIES.
}

\author{
By Joseph Augustine Cushman.
}

With fifteen plates and eight text-figures. 


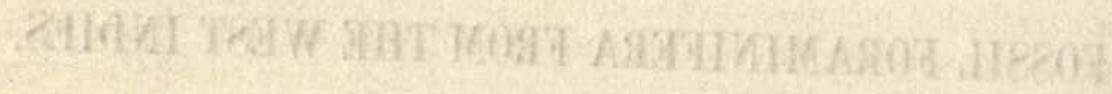

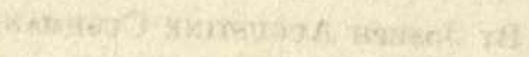




\section{FOSSIL FORAMINIFERA FROM THE WEST INDIES.}

By Joseph Augustine Cushman.

\section{INTRODUCTION.}

Very little has been known of the fossil Foraminifera of the West Indies, perhaps except Trinidad and Jamaica, and, although the present paper is based on collections from Cuba, Haiti, and Jamaica of the Greater Antilles, and from Antigua, St. Bartholomew, Anguilla, and St. Martins of the Leeward Islands, the area as a whole has still been scarcely more than touched. As the larger orbitoid genera were heretofore almost unknown from the Lesser Antilles, it is fortunate that the present collections are fairly rich in them, both in species and in individuals, because from a study of these it has been possible to make some general correlations with both continental America and with Europe. The smaller Foraminifera are at present less valuable for correlation purposes on account of the lack of the sharp discrimination of the species representing them in adjacent regions. Some of the Miocene species, however, afford a basis for definitely correlating some West Indian exposures at least with Panama and the Coastal Plain of the United States, collections from both of which I have described in reports recently published. The smaller Foraminifera, because they are very liable to exhibit differences in faunal assemblage, according to different depths and different conditions of temperature, are of value in supplying information on the physical conditions under which sediments containing them were deposited.

A summary statement regarding the collections and the general characters of the foraminiferal faunas from the different islands will be given at once, so that the data may be available for the later discussion.

\section{LEEWARD ISLANDS.}

Collections, all made by T. W. Vaughan, in 1914, from four of the Leeward Islands, viz, St. Bartholomew, Antigua, Anguilla, and St. Martin, were submitted to me. Much of the material is more or less indurated rock, and although it is very rich, especially in specimens of large forms, the species present are comparatively few. Because of their being firmly embedded in a matrix, the smaller species may be discovered only by sections, which are necessarily more or less at random. These reveal that smaller Foraminifera are numerous; but as a rule they are very unsatisfactory as they do not allow surface characters, on which specific characters so largely depend, to be studied; and from them it is usually possible to indicate little more than the genus 
to which a specimen belongs. A few of the genera are noted here for later comparisons.

In general the Foraminifera show the faunal sequence already published by Vaughan. ${ }^{1}$ The presence in St. Bartholomew of two species of Orthophragmina and associated Nummulites seems undoubtedly to indicate upper Eocene as the age of the St. Bartholomew limestone. The presence in Antigua of abundant specimens of large species of Lepidocyclina, as large as or larger than any species hitherto described, and the absence of Orthophragmina seem clearly to indicate an Oligocene age; while Orbitolites (Sorites) duplex from Anguilla and St. Martin seems to indicate a still younger horizon.

One of the species of Orthophragmina from St. Bartholomew appears to be close to a species already described from Marianna, Florida (O. mariannensis), but none similar to the other has yet been found on the continent. Nearly all the larger species are believed to be undescribed and should furnish excellent means of correlation with other West Indian or continental geologic formations.

The following table of species from the four islands contains the station numbers, the full data for which are given in the distribution of each species:

List of species of Foraminifera from the Leeward Islands.

\begin{tabular}{|c|c|c|c|}
\hline Species. & $\begin{array}{l}\text { Station } \\
\text { No. }\end{array}$ & Species. & $\begin{array}{l}\text { Station } \\
\text { No. }\end{array}$ \\
\hline \multirow{5}{*}{$\begin{array}{l}\text { From Saint Bartholomero: } \\
\text { Globigerina............... } \\
\text { Conulites americana, n. sp. } \\
\text { Carpenteria proteus, n. sp. }\end{array}$} & & \multirow{5}{*}{$\begin{array}{l}\text { From Antigua-continued } \\
\text { Lepidocyclina undulata, n.sp. }\end{array}$} & \\
\hline & 6921 & & 6863 \\
\hline & 6902 & & 6858 \\
\hline & $\begin{array}{l}6921 \\
6924\end{array}$ & & $\begin{array}{l}6880 ? \\
6881\end{array}$ \\
\hline & 6895 & & 6942 \\
\hline \multirow[t]{2}{*}{ Nummulites antillea, n. sp.. } & $\begin{array}{l}6924 \\
6895\end{array}$ & \multirow{3}{*}{$\begin{array}{l}\text { Lepidocyclina undosa, n. sp. } \\
\text { Lepidocyclina favosa, n. sp. } \\
\text { Lepidocyclina parvula, n. sp. }\end{array}$} & $\begin{array}{l}6869 \\
6881\end{array}$ \\
\hline & 6897 & & 6862 \\
\hline Nummulites parvula, n. sp. . & $\begin{array}{l}6903 \\
6924\end{array}$ & & 6854 \\
\hline Lepidocyclina antillea, n. sp. & $\begin{array}{l}6921 \\
6897 \\
6897 b \\
6902 \\
6903\end{array}$ & \multirow[t]{2}{*}{$\begin{array}{l}\text { From Anguilla: } \\
\text { Textularia................ } \\
\text { Gypsina globulus (Reuss).. } \\
\text { Nonionina.................. } \\
\text { Heterosteginoides antillea, } \\
\text { n. }\end{array}$} & $\begin{array}{l}6894 \\
6966 \\
6894\end{array}$ \\
\hline \multirow{3}{*}{ 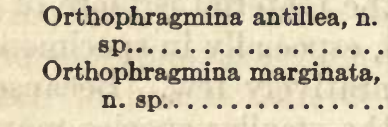 } & & & 6894 \\
\hline & 689 & & $\begin{array}{l}6965 \\
6966\end{array}$ \\
\hline & 6924 & Quinqueloculin & 6966 \\
\hline \multirow{2}{*}{$\begin{array}{l}\text { From Antigua: } \\
\quad \text { Heterostegina antillea, n. sp. }\end{array}$} & Eus & $\begin{array}{l}\text { Orbitolites duplex Carp.... } \\
\text { Alveolina } \ldots \ldots \ldots \ldots \ldots \ldots \ldots \ldots \ldots\end{array}$ & $\begin{array}{l}6894 ? \\
6966\end{array}$ \\
\hline & 6869 & & \\
\hline \multirow{3}{*}{ Lepidocyclina gigas, n. sp. . } & 6862 & Spiroloculina.. & 6949 \\
\hline & 6854 & Orbitolites duplex Carp.... & 6949 \\
\hline & 6857 & Alveolina. & 6949 \\
\hline
\end{tabular}

1 Vaughan, T. W. Study of the stratigraphic geology and of the fossil corals and associated organisms in several of the smaller West Indian Islands. Carnegie Inst. Wash. Year Book No. 13, pp. 358-360, 1914. 


\section{SANTO DOMINGO.}

The collection containing fossil Foraminifera from Santo Domingo was placed in my hands for study in connection with the work of Dr. T. W. Vaughan on other groups of the same material. The collection is that of Dr. Carlotta J. Maury of Cornell University, and represents several horizons and different localities. Only those localities at which Foraminifera were found are mentioned here.

Three localities with the following data have furnished the Foraminifera: Zone A, Rio Gurabo; Zone G, Rio Gurabo; Zone H, Rio Cana; Zone I, Rio Cana; Bluff 2, Cercado de Mao; Bluff 3, Cercado de Mao.

In all, these localities have yielded 33 species of Foraminifera. As is usual in such material, a few species dominate while the others are obtained only after long and diligent search of the finer material and are too often represented by single specimens. For this reason the occasional scattered records of one species present in one locality and not in another when the general assemblage in the two is very much alike may mean that there are certain uniques which, if the search could be prolonged indefinitely, would be represented in the similar lot of material from which it now appears to be absent. Such an explanation is probably sufficient for most of the records of this sort in Zones $\mathrm{H}$ and $\mathrm{I}$ and Bluffs 2 and 3. It explains probably the two species of Polystomella which are represented at single localities by single specimens, while the third species is common and represented at all four of the stations. It does not account for the Orbitolites, however, which is almost if not quite the most abundant genus in the Bluff 3 material and is lacking in the others. This again may be accounted for in the possible slight difference in ecologic conditions. In the tropics especially, Orbitolites is very apt to occur in great numbers under certain conditions. For example, about Montego Bay, Jamaica, Orbitolites is met with occasionally or even frequently in dredgings of several fathoms in the sand among the reefs, but about the Bogue Islands to the west of the bay, in a few inches of water, Orbitolites becomes very abundant. The short Posidonia to which the young of Orbitolites attach themselves is here abundant in the comparatively quiet waters and the specimens of Orbitolites make up a large part of the deposit about the roots of Posidonia. Some such conditions probably explain the very great abundance of Orbitolites and of Asterigerina and Amphistegina in certain of the other localities.

The geological sequence seems to present three phases at least. Zone $A$ is the youngest and is represented by but 2 species in the rather limited material at hand. Both of these species occur living at the present time and the bed containing the fossils can not be of any but late Tertiary age.

Zone $\mathrm{G}$ is represented by a single species in considerable numbers unlike anything in the other beds, but generically like those of the lower members. Its age from this seems to be Miocene. 
Zones $\mathrm{H}$ and $\mathrm{I}$, which may be considered with the material from Bluffs 2 and 3 as one unit as far as the Foraminifera are concerned, seem to be in general early Miocene, possibly upper Oligocene. The

Distribution of fossil Foraminifera, Santo Domingo.

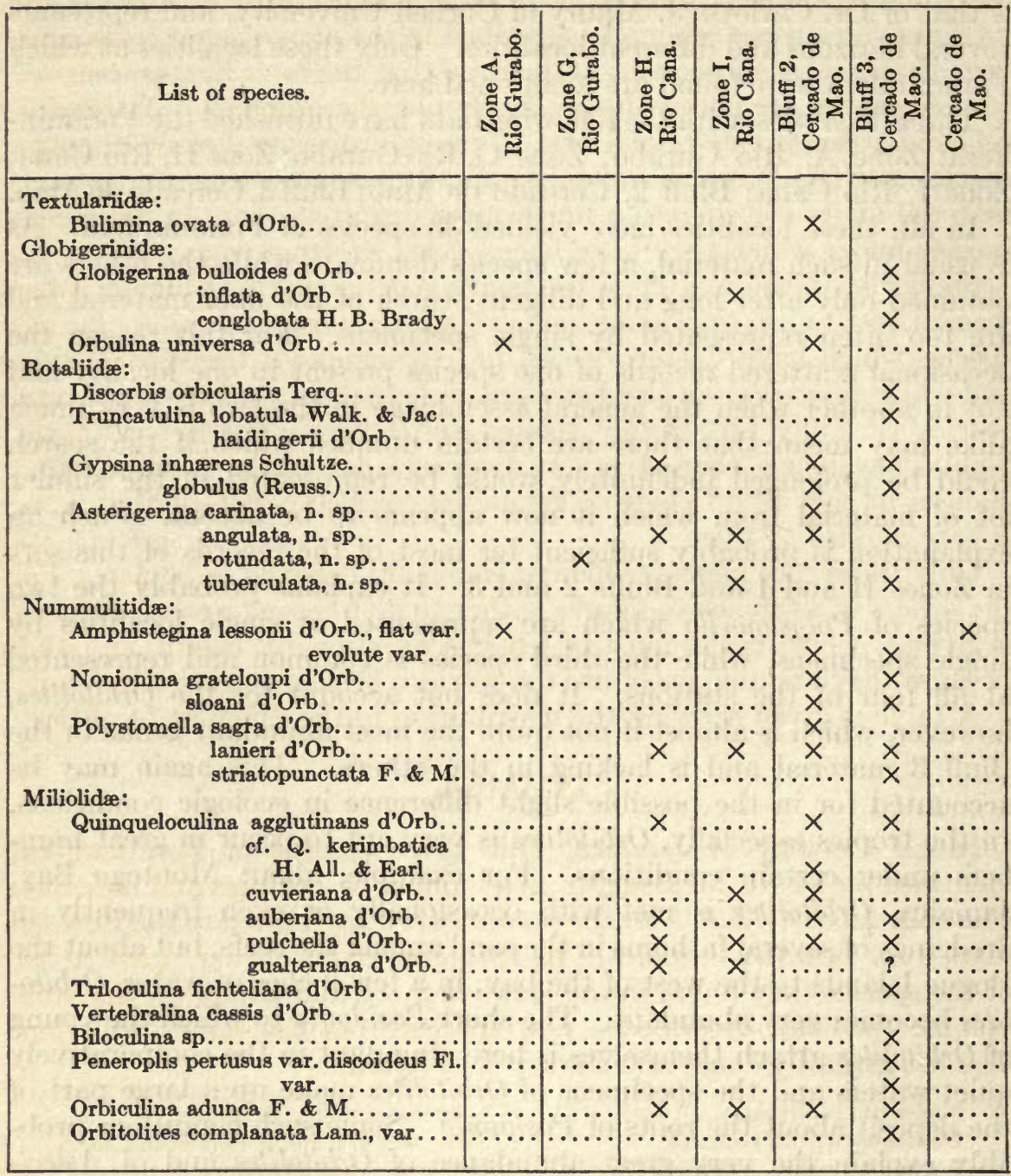

evidence would seem to favor Miocene. Here is an assemblage of 31 species, several of which are represented by abundant specimens. The foraminiferal fauna is typical of shallow-water tropical conditions, while the few specimens of Orbulina and Globigerina do not occur in sufficient numbers to indicate any considerable depth. Their presence in very small numbers is only confirmatory of the shallow-water conditions which the more abundant species clearly indicate. 
It is interesting to note that many of the species fit much more closely the original figures and descriptions given by d'Orbigny in his Cuba paper (d'Orbigny, in De la Sagra, Hist. Fis. Pol. Nat. Cuba, 1839, "Foraminifères") than they do any other later figures and descriptions, either of these same or other species. In fact, many of the d'Orbignyan species originally described in the above paper have since been changed by subsequent authors, so that the later figures assigned to such species are not at all specifically like the originals. After careful comparison it has seemed best to reestablish several of d'Orbigny's species, such as Polystomella lanieri and others, as fitting the present material under consideration much more definitely than do the recent species under which they have been placed as synonyms.

Similarly, in the matter of the genus Asterigerina d'Orbigny, it has seemed best to use that name here. While it is true that Discorbis has species which have "asterigerine" developments on the ventral side, and while Amphistegina also has similar characters, yet here are several species certainly not closely related to Discorbis nor yet with the highly developed characters of Asterigerina. Under such circumstances, as they fit d'Orbigny's genus Asterigerina perfectly, that name is here applied to them.

Only those specimens are figured which are believed to be new. For the others, a reference to figures, either to d'Orbigny or other authors, is given. A few species must be left in a questionable condition, either because they are uniques or are too worn or broken to give full details. A table is given showing the distribution in the different localities.

\section{JAMAICA.}

In his Geology of Jamaica, Hill ${ }^{1}$ gives records of Foraminifera, identified by Dr. R. M. Bagg, from a number of localitiès and horizons. The collections available for the present work are limited to the Bowden marl from Bowden, Jamaica. In 1876 Jones and Parker, ${ }^{2}$ gave a list of the species they found in the Bowden marl, and Brady, in the same volume (p. 309), described a new species from the same formation. The list given by Jones and Parker is as follows:

Nodosaria raphanistrum Linné.

Dentalina acicula Lamarck.

Vaginulina striata d'Orbigny.

Frondicularia complanata Defrance.

Cristellaria rotulata Lamarck. cultrata Montfort. calcar Linné.

\section{Cristellaria italica Defrance.}

Tinoporus vesicularis Parker and Jones.

Bulimina ovata d'Orbigny.

Cuneolina pavonia d'Orbigny.

Vertebralina (Articulina) striata d'Orbigny. Lituola soldani Parker and Jones.

\footnotetext{
${ }^{1}$ Hill, R. T. The geology and physical geography of Jamaica. Study of a type of Antillean development. Based upon surveys made for Alexander Agassiz. Bull. Mus. Comp. Zoöl., vol. 34, pp. 147 et. seq., 1899.

2 Jones, T. R., and W. K. Parker., Ann. Soc. Mal. Belg., vol. 11, Mem. pp. 91-103, 1876.
} 
Tinoporus pilaris was described by Brady.

As has already been noted in discussing the species from Santo Domingo, occasional specimens of rare species in fossil deposits are apt to be found again only after persistent search, as the chance of finding them in any definite amount of material depends upon their rarity. Therefore it is not surprising to find certain species, such as Cristellaria italica, which could hardly be mistaken for anything else, given in Parker and Jones's list from Bowden, but not seen since. A single specimen only was found, according to the original list.

In his Geology of Jamaica, Hill gives a list of the Foraminifera identified by R. M. Bagg from Bowden. Except for changes in nomenclature, this list is very similar to that given by Parker and Jones. The list as identified by Bagg follows:

Haplostiche soldanii (Parker and Jones).

Textularia barrettii (Jones and Parker). trochus d'Orbigny.

Orbiculina adunca (Fichtel and Moll). compressa d'Orbigny.

Cristellaria cultrata (Montfort). cassis (Fichtel and Moll). calcar (Linné).
Gypsina globulus (Reuss). vesicularis (Parker and Jones).

Cuneolina sp.

$$
\text { pavonia d'Orbigny. }
$$

Vaginulina legumen (Linné).

Nummulites ramondi d'Archiac.

Amphistegina lessonii d'Orbigny.

Each of these lists contains the names of 14 species, with probably 7 species in common, or a possible total of 21 species.

In this work I have had, through the kindness of Professor E. W. Berry, of Johns Hopkins University, a considerable quantity of marl from Bowden, and persistent searching has added a number of species not previously recorded, and yet has not revealed certain species listed by earlier workers; 17 of these seem to be additions to the previous lists.

Allowing for possible mistakes in identification or duplication of names, it seems fair to limit the present list to 31 species. A number of these are also found in the Miocene of Santo Domingo, Cuba, Panama, and the Coastal Plain of the United States. A few of the Bowden forms seem on critical examination to be undescribed.

The Bowden marl is characterized by an abundance of large species of Haplostiche, Cuneolina, Cristellaria, etc., which do not occur in the collections from the other Miocene formations, already referred to, and in a way seems to be unique. It is a striking fact that the same species and varieties of Haplostiche and Cuneolina are found living off the Barbados in 100 fathoms. They may live at lesser depths in the same region, but are not present in very shallow water of the tropics, so far as records are available. Cuneolina is also abundant in similar or lesser depths in the colder water off the Atlantic Coast of the eastern United States, although no published records give this. The data above given, therefore, suggest that, if the depth were slight, the water conditions were cooler than at present. The presence of Orbiculina and other Miliolidæ in very small quantities and a lack of Polystomella 
also seem to indicate that the Bowden was deposited at a considerable depth, even if it was less than 100 fathoms.

The revised list of Bowden species follows:

List of species of fossil Foraminifera from Bowden, Jamaica.

Psammosphæra fusca Schultze.

Haplostiche dubia var. dubia v. Brk.

Haddonia minor Chapman.

Texularia barrettii Jones \& Parker.

Cuneolina pavonia d'Orb.

Cuneolina pavonia var. angusta, n. var.

Bulimina ovata d'Orb.

Nodosaria vertebralis Batsch.

Frondicularia alata d'Orb.

Cristellaria calcar Linn.

bowdenensis, n. sp.

italica (Defr). gemmata H. B. Brady.

Globigerina bulloides d'Orb. rubra d'Orb. sacculifera, H. B. Brady
Globigerina subcretacea Chapman.

Spæroidina dehiscens var. immatura, n. var.

Discorbis allomorphinoides (Reuss).

Truncatulina præcincta Karrer.

Gypsina vesicularis (Parker \& Jones). globulus var. pilaris (H. B. Brady).

Pulvinulina sagra d'Orb.

Amphistegina lessonii d'Orb.

Quinqueloculina auberiana d'Orb. parkeri var. bowdenensis, n. var.

Triloculina brongniartiana d'Orb. tricarinata d'Orb.

Vertebralina striata d'Orb.

Orbiculina compressa d'Orb.

\section{CUBA.}

The Cuban collections are mainly from about Guantánamo Bay, Santiago, and Matanzas. Most of the material obtained near Santiago is from the manganese mines, and contains a great number of individuals and several species of Orthophragmina, which seems clearly to be of Eocene age. The collections from near Guantánamo are rich in Lepidocyclina and evidently represent deposits of Oligocene age. A richly fossiliferous, foraminiferal marl from near Matanzas, of Miocene age, yielded 30 species of smaller Foraminifera, a list of which is given. The table on page 30 shows the distribution at the different stations of the larger and more important species from the eastern end of the island about Santiago and Guantánamo.

Some of the Eocene species seem to be related to those of St. Bartholomew and the exposure near David, Panama.

List of species from U. S. G. S. Sta. 3461, marl gorge of Yumuri River, Matanzas, Cuba.

Textularia cf. T. candeiana d'Orb.

Bolivina limbata H. B. Brady. punctata d'Orb.

lobata var. cubensis, n. var.

Verneuilina spinulosa Reuss.

Virgulina punctata d'Orb.

Gaudryina triangularis Cushman.

Cassidulina subglobosa H. B. Brady.

Uvigerina ef. U. canariensis.

Globigerina bulloides d'Orb. subcretacea Chapman.

Orbulina universa d'Orb.

Pullenia obliqueloculata Parker \& Jones.

Anomalina.

Truncatulina lobatula Walk. \& Jac.
Siphonina retioulata (Czjzek).

Pulvinulina. pulchra, n. sp.

sagra d'Orb.

Planorbulina retinaculata Parker \& Jones.

Discorbis saulcii d'Orb.

Polystomella lanieri d'Orb. sagra d'Orb.

Nonionina cf. N. asterizans F. \& M. grateloupi d'Orb. sloanii d'Orb.

Amphistegina lessonii d'Orb.

Quinqueloculina sp.

Biloculina ef. B. bulloides d'Orb. 
This is one of the most conspicuous and commonest of the Foraminifera of the Bowden marl. It was recorded by Jones and Parker as Lituola soldanii Parker and Jones, and it is in Hill's list as Haplostiche soldanii (Parker and Jones).

The variety differs from the typical form of the species in its much more distinct chambers, more elongate tapering form, and in the curious tendency to a bending of the axis toward the apertural end.

Vanden Broeck described this variety from recent material dredged in 84 fathoms off the Barbados. I have seen some of these specimens and they are apparently identical with those from Bowden.

\section{Haddonia minor Chapman.}

Haddonia minor Chapman, Journ. Linn. Soc., Zoology, vol. 28, p. 384, plate 36, figs. 1, 2, 1902.

The following is a description of this species:

Test attached at least by the earlier chambers, afterward growing erect or in a vermiform manner; the earlier chambers often triserial, later ones variable; wall roughened somewhat; aperture horseshoe-shaped.

Length 2 to $4 \mathrm{~mm}$.

Two specimens from the Bowden marl seem very close to this species, described by Chapman from Funafuti Atoll. This is not a surprising distribution, as many things found in the Tertiary of the West Indies are represented by allied forms now living in the Indo-Pacific.

\section{TEXTULARIIDE.}

Textularia barrettii Jones and Parker.

(Plate 6, Figures 5 to 7.)

Textularia barrettii Jones and Parker, Report Brit. Assoc., Newcastle Meeting, p. 80 and p. 105, 1863; Ann. Soc. Mal. Belg., vol. 11, p. 99, woodcut, 1876; Hill, Bull. Mus. Comp. Zoöl., vol. 34, p. 147, 1899.

The following is a description of this species:

Test broadly conical, circular or somewhat compressed in end view, the compression parallel to the line of union between the series of chambers, exterior smoothly finished, wall of fine arenaceous material with a grayish cement, sutures fairly distinct but not depressed, apertural end with the line between the last-formed chambers depressed, trough-like, nearly straight, the central third slightly excavated at the aperture, which is long and low; interior of the aperture often denticulate, showing slightly at the surface; chambers labyrinthic within, the divisions radially arranged in transverse section.

Length of fossil specimens up to $3 \mathrm{~mm}$.

This species is recorded from Bowden by Jones and Parker and by Hill. It is rather a common and conspicuous species, but as far as I have seen does not reach the dimensions of recent specimens from the same general region.

In Hill's list of species identified by Dr. R. M. Bagg is Textularia trochus d'Orbigny. I have failed to find specimens of this species, 
although the younger specimens of $T$. barrettii often resemble $T$. trochus in contour, but the surface characters of the two are distinctive, as well as the size, $T$. trochus not usually exceeding a millimeter in length. The later chambers of $T$. barrettii also tend to assume a definitely cylindrical shape which is also distinctive.

Textularia species cf. T. candeiana d'Orbigny.

Textularia candeiana d'Orbigny, in De la Sagra, Hist. Fis. Pol. Nat. Cuba, "Foraminifères," p. 143, plate 1, figs. 25 to 27, 1839; Cushman, Bull. 71, U. S. Nat. Mus., part 2, p. 12 , figs. 14 to 17,1911 .

A single specimen from station 3461, marl, gorge of Yumurí River, Matanzas, Cuba, collected by T. W. Vaughan, seems to be the young of this species. The material of the test, however, has little agglutinated particles, consisting largely of clear shell material. The species was described by d'Orbigny from sands of Cuba, but it is common in shallow waters in the Indo-Pacific region.

\section{Textularia species.}

(Plate 5, Figure 7.)

A single sectioned specimen of Textularia was found in a slide from U.S.G.S. No. 6894, southwest side of Crocus Bay, Anguilla. It is elongate, composed of about 25 chambers. It is apparently the microspheric form, as the early chambers are arranged in an irregularly spiral manner. In general its shape suggests $T$. agglutinata or some related species, but determinations based on the section alone are practically valueless. The occurrence of the genus, however, should be noted both for correlation work and in order that the species may be looked for by others working on the material from the same locality at a later time.

A somewhat similar form occurs in the Cuban material from several stations. It is a form which is here figured.

Textularia species cf. T. agglutinata d'Orbigny.

(Figure 1.)

There is a large species of Textularia that occurs in the thin sections of material from a number of the Cuban stations. It is made up evidently of rather coarse sand grains, elongate, somewhat decreasing in diameter toward the apertural end. In general characters it is like T. agglutinata d'Orbigny.

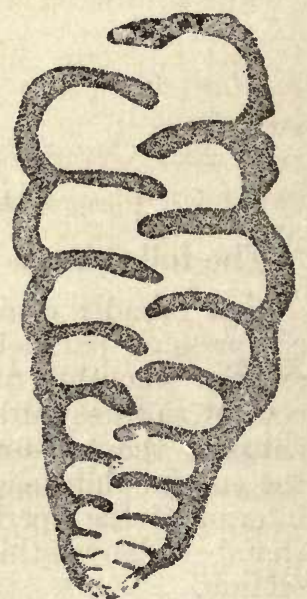

Fig.1.-Textularia cf.agglutinata d'Orbigny. Longitudinal section. $\times 35$. Specimen from station 7516, west end of Los Melones Mountain,Cuba.

As it is so large and striking a species, it has been used here to check up certain of the Cuban stations in the table. 
The species occurs in material from the following stations in Cuba, collected by O. E. Meinzer: 7512, Ocujal; 7513, orbitoidal limestone, outcrop where Palmer Trail joins Ocujal Trail; 7516, west end, Los Melones Mountain; 7521, limestone, top of Mogote Peak; 7543, limestone outcrop, east side of Yateras; and 7548, flexure, 2 miles south of Yurnaguna.

This is very similar to the specimen figured, plate 5 , figure 7 , from Anguilla.

\section{Bolivina punctata d'Orbigny.}

Bolivina punctata d'Orbigny, Voyage Amér. Mérid., vol. 5, plate 5, "Foraminifères," p. 63, plate 8 , figs. 10 to 12,1839 ; H. B. Brady, Rep. Voy. Challenger, Zoology, vol. 9, p. 417 , plate 52 , figs. $18,19,1884$.

One specimen was found in marl from station 3461, gorge of Yumurí River, Matanzas, Cuba, collected by T. W. Vaughan. It is referred to this species, although the name Bolivina punctata has had so many different forms of smooth Bolivina placed under it that it means little until a close study can be made of some of the various species now passing under that name.

This same species was found in the Miocene Gatun formation of the Panama Canal Zone.

Bolivina lobata H. B. Brady var. cubensis, new variety.

(Plate 14, Figure 1.)

The following is a description of this variety:

Test elongate, biserial, somewhat compressed, chambers of the earlier portion close, those of the later portions more distinct and somewhat separated, sutures deep and distinct, somewhat thickened, apertural end obliquely truncated; chambers with the walls more or less granular, the outer margin extended into elongate processes in most of the chambers, outline lobate; aperture elongate, oval, with a broad lip and a sharply defined border.

Length, $0.50 \mathrm{~mm}$.

Type specimen (U. S. N. M. No. 328176) from station 3461, marl from gorge of Yumurí River, Matanzas, Cuba, collected by T. W. Vaughan.

The type form of the species was described by Brady from off New Guinea, and I have seen specimens of it obtained between Midway Island and Guam. The variety above described differs in its much more spinose appearance and its broader aperture with a flaring collarlike lip.

Bolivina limbata H. B. Brady.

Bolivina limbata H. B. Brady, Quart. Journ. Micr. Sci., vol. 21, p. 57, 1881; Rep. Voy. Challenger, Zoology, vol. 9, p. 419, plate 52, figs. 26-28, 1884.

This species is represented by a single specimen from station 3461 , from marl, gorge of Yumurí River, Matanzas, Cuba, collected by T. W. Vaughan. As a recent species it is most abundant in the Indo-Pacific region, although widely distributed elsewhere in smaller numbers. 


\section{Cuneolina pavonia d'Orbigny.}

(Plate 7, Figure 1.)

Cuneolina pavonia d'Orbigny, Foram. Foss. Vienne, p. 253, plate 21, figs. 50 to 52, 1846; Cours élém. Paléont., etc., vol. 1, p. 203, fig. 30, 1849; vol. 2, plate 2, p. 648, fig. 526, 1852; Carpenter, Parker, and Jones, Introd. Foram., p. 193, plate 12, fig. 17, 1862; Jones and Parker, Ann. Soc. Mal. Belg., vol. 11, p. 98, 1876; Schwager, Boll. R. Com. Geol. Ital., vol. 8, p. 26, plate, fig. 61, 1877; Hill, Bull. Mus. Comp. Zoöl., vol. 34, p. 147, 1899.

The following is a description of this species:

Test strongly compressed in a plane parallel to that of the junction between the chambers, which are biserially arranged, nearly as wide as long, the sutures appearing at the narrow sides of the test, outline from the flattened side triangular, the apertural end broad and slightly convex, initial end pointed, in side view test narrow with nearly parallel sides, chambers slightly inflated, sutures slightly depressed, wall arenaceous with an abundance of cement, smoothly finished exteriorly; aperture extending nearly the entire width of the test, divided into a series of smaller circular or elliptical openings by prolongations of the apertural wall.

Length up to $4 \mathrm{~mm}$. or slightly more; breadth equal to the length.

This is one of the commonest and most striking of the Bowden species. D'Orbigny's figure shows a specimen fully as broad as long and from its early stages being very broad. In the Bowden material there are two forms which, although they vary somewhat, seem nevertheless worthy of distinction.

\section{Cuneolina pavonia d'Orbigny var. angusta, new variety.}

(Plate 7, Figure 2.)

The following is a description of this variety:

Test differing from the typical in its much narrower form, the length usually twice the width, slightly thicker than the typical, the chambers occasionally showing a tendency toward an angle in the center.

Length up to $5 \mathrm{~mm}$. or more.

This narrower variety is much more common than the broader typical form. Vanden Broeck did not record it from his material off Barbados, but it occurs in considerable numbers there in 100 fathoms with Haplostiche dubia var. intermedia Vanden Broeck and other species. It is also met with rather frequently off our eastern coast, although it is practically unrecorded as a recent species.

\section{Verneuilina spinulosa Reuss.}

Verneuilina spinulosa Reuss, Denkschr. Akad. Wiss. Wien, vol. 1, p. 374, plate 47, fig. 12 , 1850 ; H. B. Brady, Rep. Voy. Challenger, Zoology, vol. 9, p. 384, plate 47, figs. 1 to $3,1884$.

The species is represented by a single specimen, very typical in all its characters, from station 3461, from marl, gorge of Yumurí River, Matanzas, Cuba, T. W. Vaughan, collector. 
Gaudryina triangularis Cushman.

Gaudryina triangularis Cushman, U. S. Nat. Mus. Bull. 71, part 2, p. 65, fig. 104, 1911.

A single specimen from station 3461, marl, from gorge of Yumurí River, Matanzas, Cuba, collected by T. W. Vaughan, is very similar to this species described from the Pacific. It was found as a fossil in the lower part of the Culebra formation in the Panama Canal Zone.

\section{Bulimina ovata d'Orbigny.}

Bulimina ovata d'Orbigny, Foram. Foss. Bass. Tert. Vienne, p. 185, plate 11, figs. 13, 14, 1846.

A single specimen from Bluff 2, Cercado de Mao, which is rather too elongate for this species, but in the absence of more material it is referred here questionably. Under this name Jones and Parker record a single specimen from the Bowden marl measuring $2 \mathrm{~mm}$. in length. I have not been able to find it in the Bowden material I have examined.

\section{Virgulina punctata d'Orbigny.}

Virgulina punctata d'Orbigny, in De la Sagra, Hist. Fis. Pol. Nat. Cuba, "Foraminifères," p. 139 , plate 1 , figs. $35,36,1839$.

This species, described by d'Orbigny in the Cuba monograph, has been referred to but once since. Specimens in the material from station 3461, marl from the gorge of the Yumuri River, Matanzas, Cuba, collected by T. W. Vaughan, in their outline and form of the chambers are almost identical with the figure given by d'Orbigny.

Cassidulina subglobosa H. B. Brady.

Cassidulina subglobosa H. B. Brady, Quart. Journ. Micr. Sci., vol. 21, p. 60, 1881; Rep. Voy. Challenger, Zoology, vol. 9, p. 430, plate 54, figs. $17 a$ to c, 1884; Cushman, U.S. Nat. Mus., Bull. 71, part 2, p. 98, figs. $152 a$ to $c, 1911$.

A specimen that has an aperture like that of this species, but with the whole test somewhat more compressed, was found in the material from station 3461, marl from gorge of Yumurí River, Matanzas, Cuba, collected by T. W. Vaughan. This species is practically unknown in the fossil state.

\section{LAGENIDE.}

\section{Nodosaria vertebralis (Batsch).}

(Plate 7, Figures 3 to 5.)

Nautilus (Orthoceras) vertebralis Batsch, Conch. Seesandes, p. 3, No. 6, plate 2, figs. $6 a, b$, 1791.

Nodosaria vertebralis H. B. Brady, Rep. Voy. Challenger, Zoology, vol. 9, p. 514, plate 63 , fig. 35; plate 64, figs. 11 to 14,1884 ; Flint, Rep. U. S. Nat. Mus., p. 312, plate 57, fig. 5, 1897 (1899); Cushman, U. S. Nat. Mus., Bull. 71, part 3, p. 60, plate 32, fig. 1, 1913.

The following is a description of this species:

Test elongate, slender, somewhat tapering to the almost pointed initial end, straight or more often somewhat arcuate, chambers numerous, little inflated, sutures between the chambers of clear shell material appearing darker than the main, more opaque chamber walls; surface with a few longitudinal costæ, 
prominent, and little affected by the individual chambers, running uninterruptedly from one end of the test to the other; specimens, when complete, with a short spine at the initial end; aperture radiate, slightly produced.

Length up to $7.5 \mathrm{~mm}$.

This species is a common one in the Carribbean and Gulf of Mexico at the present time and in the Pacific tropical regions as well. Its main characteristics are the clear sutural areas between the chambers and the slightly curved elongate test. Although by no means common, well-developed specimens are found occasionally in the material from Bowden. Jones and Parker record Nodosaria raphanistrum Linné from the Bowden marl, and probably this is the same as recorded here as $N$. vertebralis. In Hill's list of species identified by Bagg no Nodosaria appears, but Vaginulina legumen (Linné). Possibly this may have been a specimen of $N$. vertebralis. Jones and Parker also record single specimens referred to Dentalina acicula Lamarck and Vaginulina striata d'Orbigny. Both of these and their N. raphanistrum are given as $5.25 \mathrm{~mm}$. in length, and it is a question if they are not perhaps all $N$. vertebralis. In all the material I have examined the only Nodosarian specimens I have seen may all be referred to $N$. vertebralis.

\section{Nodosaria species. \\ (Figure 2, $a$ and b.)}

In the sections 2 specimens of Nodosaria occur, one showing 3 , the other 4 chambers. They are small, of fairly uniform diameter, and may represent a small, few-chambered species or may be the young of some larger species, although if the latter the adults were not observed.
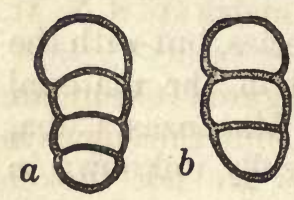

FIG. 2.-Longitudinal sections of either young or few-chambered specimens of Nodosaria. Figure $a$, four-chambered specimen from station 7519, drift near top of landslide next north of Los Melones Mountain, Cuba. Fig. $b$, three-chambered specimen from station 7513, limestone outcrop where Palmer Trail joins Ocujal Trail, Cuba.

The stations are 7513 , orbitoidal limestone, outcrop where Palmer Trail joins Ocujal Trail and 7519, from drift near top of landslide next north of Los Melones; both collected by O. E. Meinzer.

\section{Frondicularia alata d'Orbigny.}

(Plate 8, Figure 1.)

"Nautili candiformes" Soldani, Testaceographia, vol. 2, p. 13, plate 1, fig. c, 1798.

Frondicularia alata d'Orbigny, Ann. Sci. Nat., vol. 7, p. 256, No. 2, 1826. Parker, Jones, and H. B. Brady, Ann. Mag. Nat. Hist., ser. 4, vol. 8, p. 161; plate 10, fig, 66, 1871; H. B. Brady, Rep. Voy. Challenger, Zoology, vol. 9, p. 522, plate 65, figs. 20 to 23; plate 66 , figs. 3 to 5,1884 .

Frondicularia alata d'Orbigny var. lanceolata Vanden Broeck, Ann. Soc. Belg. Micr., vol. 2, p. 117, plate 2, fig. 13, 1876.

Frondicularia complanata Jones and Parker (not Defrance), Ann. Soc. Mal. Belg., vol. 11, p. 98, 1876.

The following is a description of this species:

Test flattened, in outline triangular, the chambers at the initial end forming nearly a straight base, apertural end bluntly pointed, chambers of nearly 
uniform width throughout, initial end usually with several short, blunt, conical spines extending backward, usually best developed at the angles and near the proloculum.

Length up to $7 \mathrm{~mm}$.

Jones and Parker recorded 2 specimens in their early list, "one elliptical, and another oval." In the material I have seen there are several specimens showing considerable variation. The most common form is that figured by Vanden Broeck as var. lanceolata and referred to above. In the fossil specimens spinosity of the basal margin is even more marked, in some cases as many as 3 short spines appearing from the proloculum alone and occasionally in pairs one behind the other in front view. These may appear at various parts of the basal margin. Besides this common form there are a few specimens more like Vanden Broeck's var. sagittula (e.c., plate 2, figs. 12, 14), and one at least which closely resembles the form described by him as $F$. complanata var. concinna (op. cit., plate 3, fig. 2). In general the series is not unlike that of recent material from the Carribbean and Gulf of Mexico.

Cristellaria calcar (Linné) var. aspinosa, new variety.

(Plate 6, Figure 8.)

The following is a description of this variety:

Test small, close-coiled, biconvex, umbonate, smooth, sutures not depressed, peripheral margin acute, with a distinct but very narrow carina with a very slight knob-like spine opposite each chamber.

Diameter about $0.75 \mathrm{~mm}$.

Type specimen from the Miocene Bowden marl, Jamaica (U.S.N.M. No. 328177).

This is very close to the typical form of $C$. calcar as figured (Cushman, Bull. 71, U. S. Nat. Mus., part 3, plate 32, figure 4), but the spines in the Bowden specimens are nearly obsolete. These are not broken spines, but are really shortened and knob-like or almost wanting. It is rare in the Bowden material.

\section{Cristellaria bowdenensis, new species.}

(Plate 8, Figure 2.)

The following is a description of this species:

Test comparatively large, much compressed, chambers long and narrow, broadening somewhat toward the periphery, sutures gently curved; peripheral margin with a thin keel of medium width prolonged at irregular intervals into a series of rowel-like spines, short, rounded near the base, and apparently having little relation to the chambers; surface of the chambers smooth, the sutures typically raised, limbate, with a series of tubercles running from the umbilical area to the periphery; aperture somewhat back from the periphery in the last-formed chambers, really terminal in the young, and early chambers peripheral, stellate.

Diameter up to $4 \mathrm{~mm}$. 
Type specimen from the Miocene Bowden marl, Jamaica (U.S.N.M. No. 328178).

This is a fairly common species at this locality and is the one from Bowden referred to by various authors as Cristellaria calcar. It is not typical C. calcar and seems to be distinctive in its size, form, and ornamentation. The nearest approach to it is perhaps the form described from the Carribbean by Goës (Kongl. Svensk. Vet. Akad. Handl., vol. 19 , No. 4 , p. 49 , plate 3 , figs. $3,50,51,1888$ ) under the name Nodosarina crepidula var. cassis (Fichtel and Moll).

\section{Cristellaria gemmata H. B. Brady.}

Cristellaria gemmata H. B. Brady, Quart. Journ. Micr. Soc., vol. 21, p. 64, 1881; Rep. Voy. Challenger, Zoology, vol. 9, p. 554, plate 71, figs. 6, 7, 1884.

A single very typical specimen of this species was obtained from the Bowden marl, Bowden, Jamaica. Brady's records of its occurrence as a recent species include the Fiji Islands, Torres Strait, and the Philippines.

\section{Cristellaria italica (Defrance).}

Saracenaria italica Defrance, Dict. Sci. Nat., vol. 32 , p. 177, 1824; vol. 47, p. 344; Atlas Conch., plate 13, fig. 6 .

Cristellaria (Saracenaria) italica d'Orbigny, Ann. Sci. Nat., vol. 7, p. 293, 1826.

Cristellaria italica Parker, Jones, and H. B. Brady, Ann. Mag. Nat. Hist., ser. 3, vol. 16, pp. 21, 31, plate 1, figs. 41, 42, 1865; Jones and Parker, Ann. Soc. Mal. Belg., vol. 11, p. 98, 1876; H. B. Brady, Rep. Voy. Challenger, Zoology, vol. 9, p. 544, plate 68, figs. $17,18,20,23,1884$.

Jones and Parker, in their list of species from the Bowden marl, record a single specimen of this species, measuring about $6 \mathrm{~mm}$. in length. That is about the size of large recent specimens from this same general region. I have not found the species in the material I have examined from the Bowden, but it occurs in material from the Panama Canal Zone.

\section{Polymorphina species. \\ (Plate 8, Figure 4.)}

In the sections from station 7664, north slope La Piedra, northeast of Jamaica, northeast of Guantánamo, collected by N. H. Darton, there are specimens of a large species of Polymorphina, with fairly thick walls. One of these is figured in the reference given above.

\section{GLOBIGERINIDE.}

\section{Globigerina bulloides d'Orbigny.}

Globigerina bulloides d'Orbigny, Ann. Sci. Nat., vol. 7, p. 277, No. 1, 1826; in Barker, Webb, and Berthelot, Hist. Nat. Isles Canaries, "Foraminifères," p. 132, plate 2, figs. 1, 3, 28, 1839; Foram. Foss. Bass. Tert. Vienne, p. 163, plate 9, figs. 4, 6, 1846; H. B. Brady, Rep. Voy. Challenger, Zoology, vol. 9 , p. 593, plate 77, plate 79 , figs. 3 to $7,1884$.

A few specimens of this common species occur in the Bowden, Jamaica, material, accompanied as usual by some specimens which 
may be referred to variety triloba Reuss. A few specimens were also obtained in material from Bluff 3, Cercado de Mao, Santo Domingo.

This species occurs in the Miocene both of Panama and the Coastal Plain of Florida and Virginia.

\section{Globigerina rubra d'Orbigny.}

Globigerina rubra d'Orbigny, in De la Sagra, Hist. Fis. Pol. Nat. Cuba, 1839, Foraminifères, p. 94, plate 4, figs. 12 to 14 ; H. B. Brady, Rep. Voy. Challenger, Zoology, vol. 9, p. 602 , plate 79 , figs. 11 to 16,1884 .

A single specimen was found which seems referable to this common species so characteristic of the Caribbean region. It is from Jamaica, from the Bowden marl.

\section{Globigerina sacculifera H. B. Brady.}

Globigerina helicina Carpenter (not G. helicina d'Orbigny), Intr. Foram., plate 12, fig. 11, 1862. Globigerina sacculifera H. B. Brady, Geol. Mag., Dec. 2, vol. 4, p. 535, 1877; Rep. Voy. Challenger, Zoology, vol. 9, p. 604 , plate 80 , figs. 11 to 17 , plate 82 , fig. 4,1884 .

One or two specimens are very evidently this common species, so common in Globigerina ooze of recent ocean bottoms, but almost unknown as a fossil species. They occurred in the Bowden marl from Jamaica.

\section{Globigerina subcretacea Chapman.}

Globigerina cretacea H. B. Brady (not G. cretacea d'Orbigny), Rep. Voy. Challenger, Zoology, vol. 9 , p. 596 , plate 82 , fig. 10,1884 .

Globigerina subcretacea Chapman, Journ. Linn. Soc., Zoology, vòl. 28, p. 410, plate 36, figs. $16 a, b, 1902$.

A single specimen of this species was obtained in the material from Bowden, Jamaica.

Globigerina inflata d'Orbigny.

Globigerina inflata d'Orbigny, in Barker, Webb, and Berthelot, Hist. Nat. Iles Canaries, "Foraminifères," p. 134, plate 2, figs. 7 to $9,1839$.

A few specimens from Zone I, Rio Cana, and also from both Bluffs 2 and 3, Cercado de Mao, Santo Domingo. It is also known from the Miocene of the Panama Canal Zone.

\section{Globigerina conglobata H. B. Brady.}

Globigerina conglobata H. B. Brady, Rep. Voy. Challenger, Zoology, vol. 9, p. 603, plate 80, figs. 1 to 5,1884 .

A single typical specimen from Bluff 3, Cercado de Mao, Santo Domingo. The species also occurs in the Miocene of the Panama Canal Zone.

\section{Globigerina species.}

(Plate 5, Figure 13.)

A small species of Globigerina in the section illustrated, reminding one of G. cequilateralis, occurs at U.S.G.S. No. 6924 from limestone point on northwest side of St. Jean Bay, St. Bartholomew. As the sections do not give the entire form it is impossible to identify it specifically with any certainty. 
Globigerina species.

(Plate 8, Figure 3.)

A small species of Globigerina is very common in the sections of rock specimens from Cuba. It occurred at station 7513, orbitoidal limestone, outcrop where Palmer Trail joins Ocujal Trail; station 7516, west end, Los Melones; and station 7521, limestone, top of Mogote Peak; all collected by O. E. Meinzer. The figured specimen which seems to be the same is from station 7664, north slope La Piedra, northeast of Jamaica, northeast of Guantánamo, collected by N. H. Darton.

Orbulina universa d'Orbigny.

Orbulina universa d'Orbigny, in Barker, Webb, and Berthelot, Hist. Nat. Iles Canaries "Foraminifères," p. 123, plate 1, fig. 1, 1839.

Single specimens occurred in material from Zone A, Rio Gurabo, and Bluff 2, Cercado de Mao, Santo Domingo. It is known also from the Miocene of the Panama Canal Zone.

\section{Sphæroidina dehiscens Parker and Jones var. immatura, new variety.}

(Plate 14, Figure 2.)

The following is a description of this variety:

Test exteriorly composed almost entirely of two visible chambers, with a small portion of a third sometimes slightly showing; chambers spherical, walls coarsely perforate, suture between the chambers very slightly fissure-like on opposite sides, otherwise closed and simply depressed.

Diameter 0.4 to $0.5 \mathrm{~mm}$.

All of the specimens from the Bowden marl seem to belong to this species, but they are very constant in having the characters only slightly developed, the usual separation of the chambers being barely indicated and the division, instead of being a deep-cut fissure, is merely a simple cut in the central part of the sutural region at either side. The specimens also are very small, but are uniform in size and in general characters. A number of specimens were obtained.

\section{Pullenia obliqueloculata Parker and Jones.}

Pullenia obliqueloculata Parker and Jones, Philos. Trans., vol. 155, p. 368, plate 19, figs. $4 a$, b, 1865; H. B. Brady, Rep. Voy. Challenger, Zoology, vol. 9, p. 618, plate 84, figs. 16 to 20, 1884; Flint, Rep. U. S. Nat. Mus., 1897, p. 324, plate 70, fig. 6 (1899); Cushman, Bull. 71, U. S. Nat. Mus., part 4, p. 22, plate 10, fig. 3; plate 12, figs. $2,3,1914$.

This species is very rare in the marl from station 3461, gorge of Yumurí River, Matanzas, Cuba, collected by T. W. Vaughan. It is a very rare species in the fossil state.

\section{ROTALIIDE.}

\section{Discorbis orbicularis (Terquem).}

Discorbina orbicularis (Terquem), H. B. Brady, Rep. Voy. Challenger, Zoology, vol. 9, p. 647, plate 98 , figs. 4 to 8,1884 .

A single specimen was found in the material from Bluff 3, Cercado de Mao, Santo Domingo. 


\section{Discorbis saulcii (d'Orbigny).}

Rosalina saulcii d'Orbigny, Foram. Amér. Mérid., p. 42, plate 2, figs. 9 to 11, 1839.

Discorbina saulcii Parker and Jones, Quart. Journ. Geol. Soc., vol. 28, p. 156, 1872; H. B. Brady, Rep. Voy. Challenger, Zoology, vol. 9, p. 653, plate 91, figs. $6 a$ to $c, 1884$.

Most of the records for this species are from the Pacific. The specimens from station 3461, marl, gorge of Yumuri River, Matanzas, Cuba, collected by T. W. Vaughan, are very similar to the published figures.

\section{Discorbis allomorphinoides (Reuss).}

Valvulina allomorphinoides Reuss, Sitz. Akad. Wiss. Wien, vol.40, p. 223, plate 11, fig. 6, 1860.

Discorbina allomorphinoides H. B. Brady, Rep. Voy. Challenger, Zoology, vol. 9, p. 654, plate 91 , figs. 5 and 8,1884 .

Several specimens from the Bowden marl, Bowden, Jamaica, are very close to Brady's figures, especially plate 91 , figure 5 in the Challenger report, referred to above. Reuss's material was from the Cretaceous of Westphalia, and I am not at all satisfied that Brady was justified in referring the recent specimens from Torres Strait and the Philippines to Reuss's species. It seems more than likely that the IndoPacific recent specimens and those from the Miocene of the West Indies may be identical, as there are numerous other instances of West Indian Miocene species persisting in the living fauna of the Indo-Pacific.

Planorbulina retinaculata Parker and Jones.

Planorbulina retinaculata Parker and Jones, Phil. Trans., vol. 155, p. 380, plate 19, fig. $2,1865$.

A single specimen with irregularly placed chambers, very coarsely perforate, and with the peripheral spinose character of the type figure, was found at station 3461, marl from gorge of Yumurí River, Matanzas, Cuba, collected by T. W. Vaughan. The type specimens were from the tropics.

\section{Truncatulina lobatula (Walker and Jacob).}

Truncatulina lobatula (Walker and Jacob), H. B. Brady, Rep. Voy. Challenger, Zoology, vol. 9 , p. 660 , plate 92 , fig. 10 ; plate 93 , figs. $1,4,5,1884$.

A single specimen was found in material from Bluff 3 , Cercado de Mao, Santo Domingo. The later chambers are somewhat irregular, as is often the case in attached recent specimens. The species also occurs in the Miocene of South Carolina and Virginia.

Truncatulina haidingerii (d'Orbigny).

Rotalina haidingerii d'Orbigny, Foram. Foss. Bass. Tert. Vienne, p. 154, plate 8, figs. 7 to 9, 1846.

A single specimen from Bluff 2, Cercado de Mao, Santo Domingo.

Truncatulina præcincta (Karrer).

Rotalia procincta Karrer, Sitz. Akad. Wiss. Wien., vol. 58, p. 189, plate 5, fig. 7, 1868; Seguenza, Atti. Accad. Lincei, ser. 3, vol. 6, pp. 56, 64, 1897.

Truncatulina pracincta H. B. Brady, Rep. Voy. Challenger, Zoology, vol. 9, p. 667, plate 95, figs. 1 to 3,1884 .

The following is a description of this species:

Test free, biconvex, dorsal side slightly, ventral side strongly, peripheral margin bluntly rounded, chambers numerous, sutures on dorsal side oblique, 
ventrally slightly curved, line between the whorls clearly marked by a raised rounded ridge of clear shell material, sutures ventrally marked in a similar manner, strongest toward umbilicus, where they often unite in a raised ring; aperture elongate, in the middle of the ventral side next to the previous whorl.

Diameter about $1 \mathrm{~mm}$.

Several specimens of this species were found in the Bowden material from Jamaica. It is a species which as a recent one is practically confined to tropical and subtropical regions. It was described by Karrer from the Miocene of the Banat region of Hungary and has been recorded from the Miocene and Pliocene of Italy by several authors.

\section{Siphonina reticulata (Czjzek).}

Rotalina reticulata Czjzek, Haidinger's Nat. Abh., vol. 2, p. 145, plate 13, figs. 7-9, 1848.

Siphonina reticulata Bronn, Lethæa Geognostica, ed. 3, vol. 3, p. 227, plate 35, figs. $23 a$ to c, 1853-1856; Cushman, Bull. 71, U. S. Nat. Mus., part 5, p. 43, fig. 48 (in text), plate 16, fig. 4, plate 28, fig. 3, 1915.

Truncatulina reticulata H. B. Brady, Rep. Voy. Challenger, Zoology, vol. 9, p. 669, plate 96, figs. 5 to 8,1884 .

There are a few specimens referable to this species in the marl from station 3461, gorge of Yumurí River, Matanzas, Cuba, collected by T. W. Vaughan. It was recorded from the Miocene, Gatun formation, at Monkey Hill, in the Panama Canal Zone.

Various forms or species are present in the Tertiary of America and need careful study and separation rather than the general lumping of all these under the one name of $S$. reticulata, as has been the usual procedure. The following species is very different and distinct.

\section{Siphonina pulchra, new species.}

(Plate 14, Figures $7 a$ to c.)

The following is a description of this species:

Test in front view nearly circular, rotaliform, composed of numerous chambers in several whorls, in end view much compressed, widest in the central region. Thence gradually tapering to the subacute periphery; chambers usually about 5 to each whorl, indistinct, except the last-formed chamber, which is somewhat more clearly defined by the slightly depressed suture, those of the other chambers being even with the surface and very indistinct; aperture exsert, with a short neck extending out from the periphery, passing into a broadly flaring lip with a distinct, extended border, aperture itself narrowly elliptical, several times as long as wide; wall of test of a darker gray with markings of a lighter color, those of the center rounded, those toward the periphery more linear; diameter about $1 \mathrm{~mm}$.

Type specimen from Cuba, station 3461, in marl from gorge of Yumurí River, near Matanzas.

This is a much larger species than the other of the same genus that occurs with it and here referred to S. reticulata. S. pulchra has no fimbriated periphery and practically no keel, which with its larger size and peculiar ornamentation will serve to distinguish it. 
Conulites americana, new species.

The following is a description of this species:

Test conical, height about two-thirds the width at the base, apex broadly rounded, base slightly convex, peripheral angle subacute, the peripheral region standing out somewhat from the general conical mass of the rest of the test; early chambers spirally arranged, later ones annular, exterior of test in section tubular, central portion made up of irregularly curved chambers, more or less irregularly divided into labyrinthic subdivisions; surface fairly smooth.

Diameter at base slightly less than $2 \mathrm{~mm}$.

Type specimen (U. S. N. M. No. 328179), section from station 6902 , southeast section of southwest side of island near Nègre Point, elevation 360 feet, St. Bartholomew, Leeward Islands. Sectioned specimens were also observed in material from the following stations in Cuba: 3448, limestone from hillside south of Panupo manganese mine, La Maya, near Santiago, collected by T. W. Vaughan; 3478 , Nuevitas, collected by A. C. Spencer; 7666 , from Sierra Guaso, northeast

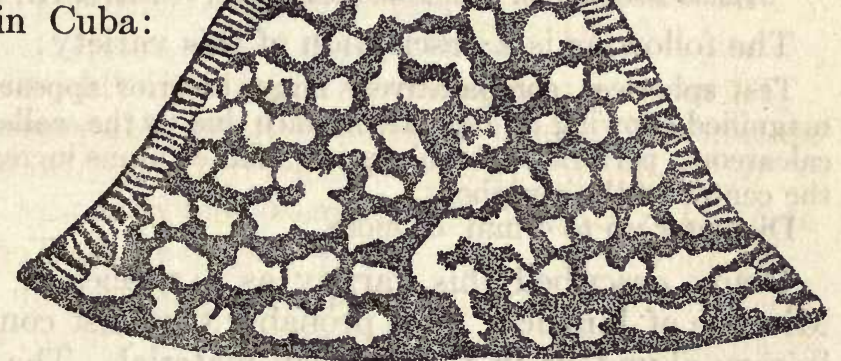

FIa. 3.-Conulites americana, new species. Vertical section showing coarser structure and outer layer with fine tubules. $\times 35$. Specimen from station 6902, St. Bartholomew, Leeward Islands. of Guantánamo, collected by N. H. Darton.

This is similar to the C. cegyptiensis Chapman from the Eocene of Egypt and Italy, but differs in its general proportions and in the flange-like extension of the peripheral border at the base.

\section{Gypsina vesicularis (Parker and Jones).}

Orbitolina vesicularis Parker and Jones, Ann. Mag. Nat. Hist., ser. 3, vol. 6, p. 31, No. 5, 1860. Tinoporus vesicularis Carpenter, Introd. Foram., p. 224, plate 15, figs. 1 to 4, 1862; Parker and Jones, Ann. Soc. Mal. Belg., vol., 11, p. 98, 1876.

Gypsina vesicularis Carter, Ann. Mag. Nat. Hist., ser. 4, vol. 20, p. 173, 1877; H. B. Brady, Rep. Voy. Challenger, Zoology, vol. 9 , p. 718 , plate 101, figs. 9 to 12, 1884; Hill, Bull. Mus. Comp. Zoöl., vol. 34, p. 147, 1899.

Parker and Jones and also Hill record this species from the Bowden marl of Jamaica, but I have failed to find it in that I have examined. Parker and Jones mention a single specimen, $4.75 \mathrm{~mm}$. in size.

\section{Gypsina inhærens (Schultze).}

Gypsina inhorens (Schultze) H. B. Brady, Rep. Voy. Challenger, Zoology, vol. 9, p. 718, plate 102, figs. 1 to $6,1884$.

Specimens which are evidently of this species were collected at three stations: several specimens at Bluff 3, Cercado de Mao; rare at Bluff 2, Cercado de Mao; and Zone H, Rio Cana, Santo Domingo. 
Gypsina globulus (Reuss).

(Plate 4, Figure 7.)

Ceriopora globulus Reuss, Haidinger's Nat. Abh., vol. 2, 1847, p. 33, plate 5, fig. 7.

Gypsina globulus H. B. Brady, Rep. Voy. Challenger, Zoology, vol. 9, p. 717, plate 101, fig. 8, 1884.

In the material from U. S. G. S. No. 6966, southwest shore of Crocus Bay, Anguilla, occasional specimens occur which seem to belong to this species. A median section of a small specimen is shown here. There does not seem to be the definite radial arrangement of chambers that is usually the case in the fossil specimens of this species. I have the species in fossil condition from Santo Domingo. Two specimens were found at Bluff 2 and a single one at Bluff 3, Cercado de Mao.

Gypsina globulus (Reuss) var. pilaris (H. B. Brady).

(Plate 9, Figures 1, 2.)

Tinoporus pilaris H. B. Brady, Ann. Soc. Mal. Belg., vol. 11, p. 103, 1876.

Gypsina globulus Hill, Bull. Mus. Comp. Zoöl., vol. 34, p. 147, 1899.

The following is a description of this variety:

Test spherical, comparatively large, exterior appearing smooth, but when magnified showing an areolate surface due to the walls of the chambers; wall calcareous, perforate; chambers in radial columns increasing in diameter from the center to the periphery.

Diameter up to $4 \mathrm{~mm}$. or more.

Brady described this variety as a species of Tinoporus from the Miocene of Jamaica. It is probably the most conspicuous species and is very abundant in the Bowden material. The variety differs from typical $G$. globulus mainly in size, the typical having a much smaller test. Plate 9, figure 2, gives a general idea of the internal structure of the test.

There are specimens from station 3446 , first deep cutting on railroad east of La Cruz, near Santiago, Cuba, collected by T. W. Vaughan, which in size, shape, and general characters seem very close to this variety. The internal structure, as far as it is preserved, seems also to be identical with the Bowden material. The geologic occurrence of these specimens is in the Miocene La Cruz marl.

\section{Gypsina species.}

Sectioned specimens from 3 stations in Cuba showed what seem to be sections of Gypsina. They are associated in each case with Lepidocyclina and Carpenteria. The stations are 7513, outcrops where Palmer Trail joins Ocujal Trail; 7521, limestone in place, top of Mogote Peak; and 7522, also Mogote Peak; collected by O. E. Meinzer.

Pulvinulina sagra (d'Orbigny).

Rotalina sagra d'Orbigny, in De la Sagra, Hist. Fis. Pol. Nat. Cuba, "Foraminifères," p. 77, plate 5 , figs. 13 to 15,1839 .

Specimens from the Bowden marl, Bowden, Jamaica, and from station 3461, marl from the gorge of Yumurí River, Matanzas, Cuba, collected by T. W. Vaughan, seem to be identical with the species 
described by d'Orbigny from Cuba in 1839. The exact proportions and relations of the chambers that are shown in d'Orbigny's figures are found in the fossil specimens. The species is known from the Miocene of Florida and Virginia, and probably occurs in Panama as well. It is a common species in the Indo-Pacific.

\section{Rotalia species.}

(Plate 8, Figure 6.)

A small, close-coiled, rotaliform species with numerous chambers in each volution occurs at a number of the Cuban stations, as follows: 7512, Ocujal; 7513, orbitoidal limestone, outcrop where Palmer Trail joins Ocujal Trail; 7516, west end, Los Melones Mountain; 7519, from drift near top of landslide next north of Los Melones; and 7543, limestone outcrop, east side of Yateras; all collected by O. E. Meinzer.

\section{Asterigerina carinata d'Orbigny.}

Asterigerina carinata d'Orbigny, in De la Sagra, Hist, Fis. Pol. Nat. Cuba, 1839, "Foraminifères," p. 118, plate 5, fig. 25, plate 6, figs. $1,2$.

A very typical specimen came from Bluff 2, Cercado de Mao, Santo Domingo.

\section{Asterigerina angulata, new species.}

(Plate 13, Figure 1.)

The following is a description of this species:

Test free, rotaliform, dorsal side very slightly convex, ventral side high, acutely angled at the peripheral edge but not carinate; last-formed whorl with typically about 15 chambers; sutures on the dorsal side obliquely recurved, of clearer material than the chamber walls, occasionally with a slight beadlike enlargement on the inner border, earlier whorls slightly exposed and the umbonate region with a transparent clear area; ventral side with the sutures ending in an angle about midway between the center and the periphery, from which a secondary chamber is developed to the umbilical region, alternating with the main chambers; umbilical region solid, of clearer shell material; aperture rather long and narrow at the inner margin of the ventral face; surface granular or slightly papillate, especially about the aperture.

Average diameter 1.5 to $2 \mathrm{~mm}$.

Specimens of Asterigerina angulata are frequent or abundant at the four stations-Zones $\mathrm{H}$ and I, Rio Cana, and Bluffs 2 and 3, Cercado de Mao, Santo Domingo.

It is thicker species than $A$. carinata d'Orbigny; and it has an acute but not carinate angle and nearly double the number of chambers.

\section{Asterigerina rotundata, new species.}

(Plate 13, Figure 2.)

The following is a description of this species:

Test free, rotaliform, biconvex, dorsal side less convex than the ventral, peripheral angle broadly rounded; last-formed coil with 15 to 18 chambers; sutures on the dorsal side gently recurved, slightly limbate, earlier whorls exposed and forming nearly half the width of the dorsal side of the test 
ventral side with the sutures very similar to those of $A$. angulata; the umbilicate region solid, with clearer shell material; surface of test granular throughout, opaque, causing the sutures on both sides to be indistinct; aperture ventral, elongate.

Diameter, 1 to $1.25 \mathrm{~mm}$.

This species was found in considerable numbers at Zone G, Rio Gurabo, Santo Domingo. It differs from $A$. angulata in its rounded periphery, granular, opaque surface, broadly rounded ventral side, and inconspicuous sutures.

\section{Asterigerina tuberculata, new species.}

(Plate 13, Figures 3, 4.)

The following is a description of this species:

Test free, rotaliform, biconvex, becoming truncate and short cylindical, peripheral angle in young subangular, becoming rounded in the adult, outline regular in the early stages, in the adult becoming lobed, especially in the last few chambers; dorsal surface rather flat, slightly convex, conspicuously pitted or scrobiculate, last-formed coil narrow, making only the extreme peripheral portion in the adult on the dorsal side; ventral side with large tubercles or knobs developed near the peripheral border, remainder of surface with coarse granulations; in some specimens the height of the test equals its diameter and the ventral and dorsal sides are nearly parallel; the periphery high and flattened to make a short cylindical test; sutures as typical in the genus; aperture ventral, narrow.

Diameter up to $2 \mathrm{~mm}$.

Specimens were obtained from Zone I, Rio Cana, and a single one from Zone 3, Cercado de Mao, Santo Domingo.

This is a peculiarly ornamented and shaped species, the change in outline during development being very marked, as is the very strongly tuberculate ornamentation.

Carpenteria americana, new species.

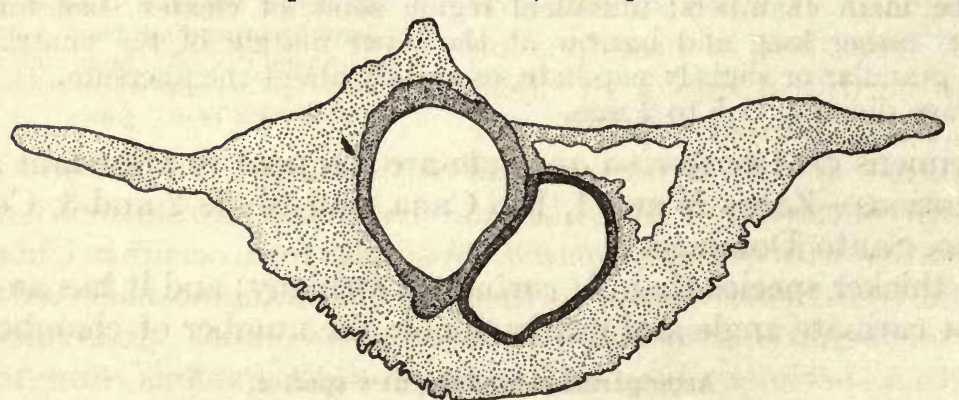

Fig. 4.-Carpenteria americana new species. Transverse section of a specimen showing deeplypitted surface of shell tissue surrounding chambers. $\times 35$. From station 7518, south side, near west end, Los Melones Mountain, Cuba.

The following is a description of this species:

Test attached, composed of several subglobular chambers forming an irregular Globigerina-like mass, the base conforming to the object to which 
it is attached, the rest of the test in an irregular rounded mass; chambers rounded, thick-walled, with numerous coarse, tubular perforations.

Diameter 2 to $3 \mathrm{~mm}$.

Distribution.-Specimens referable to this species occurred in the sectioned material from the following stations in Cuba: 7513, outcrops where Palmer Trail joins Ocujal Trail; 7518, south side near west end, Los Melones Mountain; 7521, limestone in place, Mogote Peak; 7522, also Mogote Peak, collected by O. E. Meinzer; and at 7664, north slope La Piedra, northeast of Jamaica, northeast of Guantánamo, collected by N. H. Darton.

\section{Carpenteria proteus, new species.}

(Plate 5, Figure 3.)

The following is a description of this species:

Test composed of a few subglobular chambers, the smaller end attached, the later chambers larger and extending upward, forming a roughly club-shaped column, walls thick but rather finely perforate, the exterior comparatively smooth.

Length 2 to $3 \mathrm{~mm}$.

Type specimen (U. S. N. M. No. 328180 ), section from station 6921 , Governor's Bay, point between the bay and Grand or Nègre Point, St. Bartholomew, collected by T. W. Vaughan. It was also collected at 6924 , from bed of limestone on point on northwest side of St. Jean Bay, St. Bartholomew, and 6895, spur

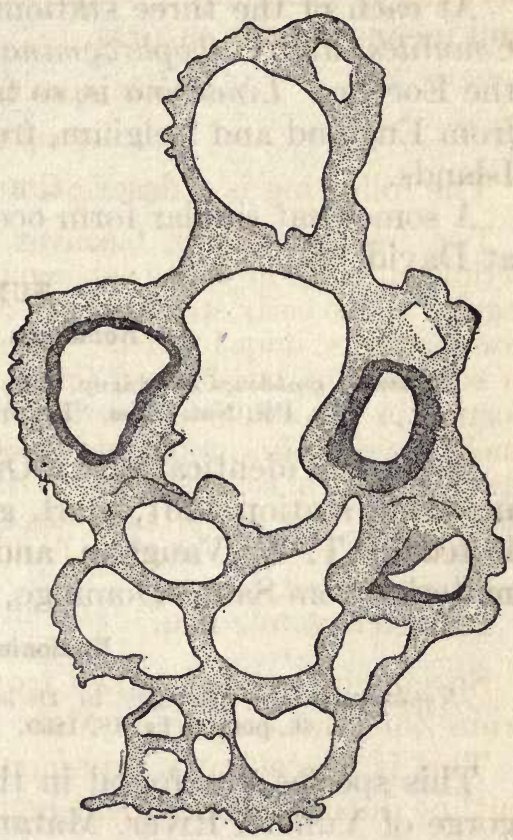

FIG. 5.-Carpenteria americana, new sp. A longitudinal section through a welldeveloped specimen, longest part of figure representing basal portion of specimen. $\times 50$. From station 7513 , limestone outcrop where Palmer Trail joins Ocujal Trail. Cuba. on southeast side of cay northwest of St. Jean Bay, 170 feet above sealevel, both collected by T. W.Vaughan. In the last two stations it occurs in association with Orthophragmina. A similar form occurs in Cuba,station 7666, from Sierra Guaso, northeast of Guantánamo, collected by N. H. Darton, again in association with Orthophragmina. It is also very similar to a specimen obtained at station 6512, Panama, limestone in river-bed at David, which specimen is also associated with Orthophragmina.

Linderina species.

(Plate 8, Figures 7 and 8.)

A few sectioned specimens which seem to represent Foraminifera belonging to this genus occur in association with Conulites americana 
at the three stations in Cuba, as follows: Station 3448, limestone from hillside south of Panupo manganese mine, La Maya, near Santiago, collected by T. W. Vaughan; 3478, Nuevitas, collected by A. C. Spencer; and 7666, Sierra Guaso, northeast of Guantánamo, collected by N. H. Darton. It was also obtained at station 6125 , railroad cut near San Nicolas manganese mine, west of San Luis, by C. W. Hayes. The two figured specimens give only a somewhat general idea of the sections.

At each of the three stations there is an association of Linderina?, Conulites, and Orthophragmina, three genera usually associated with the Eocene. Linderina is, so far as known, an Eocene genus, recorded from England and Belgium, from Celebes, Borneo, and the Loo Choo Islands.

A somewhat similar form occurs at station 6512, Panama, river-bed at David.

NUMMULITIDE.

Nonionina grateloupi d'Orbigny.

Nonionina grateloupi d'Orbigny, Ann. Sci. Nat., vol. 7, p. 294, 1826; in De la Sagra, Hist. Fis. Pol. Nat. Cuba, "Foraminifères," p. 46, plate 6, figs. 6, 7, 1839.

Specimens identical with d'Orbigny's figures were found in the Cuban material, station 3461, marl, gorge of Yumurí River, Matanzas, collected by T. W. Vaughan, and a single specimen in Doctor Maury's material from Santo Domingo, Bluff 3, Cercado de Mao.

\section{Nonionina sloani d'Orbigny.}

Nonionina sloani d'Orbigny, in De la Sagra, Hist. Fis. Pol. Nat. Cuba, "Foraminifères," p. 46, plate 6, fig. 18,1839 .

This species was found in the Cuban material, station 3461, marl, gorge of Yumurí River, Matanzas, collected by T. W. Vaughan, and a single specimen in Doctor Maury's material from Bluff 2, Cercado de Mao, Santo Domingo.

\section{Nonionina species cf. N. asterizans (Fichtel and Moll).}

Nautilus asterizans Fichtel and Moll, Test. Micr., p. 37, plate 3, figs. $e$ to $h, 1803$.

Pulvinulus asterizans Lamarck, Tab. Encycl. et Method., plate 23, plate 466, figs. $10 a$ to $d$, 1816.

Nonionina asterizans Parker and Jones, Ann. Mag. Nat. Hist., ser. 2, vol. 19, p. 287, plate 11, figs. $20,21,1857$.

A specimen from station 3461, marl from gorge of Yumurí River, Matanzas, Cuba, collected by T. W. Vaughan, has many of the characters of this species, but differs in the smaller amount of the umbilical projections and rounder outline from the published figures. It is referred here provisionally.

\section{Nonionina species.}

(Plate 5, Figure 11; Plate 8, Figure 5.)

Occasional specimens occur in the sections as shown in the figure, apparently sections of a small species of Nonionina. The specimen illustrated by plate 5, fig. 11, is from Anguilla, U.S.G.S. No. 6894, 
southwest side of Crocus Bay. Sections, plate 8, fig. 5, which also seem to be Nonionina occur in the material from station 6117 from the band of limestone, hill east of railroad and south of Cristo, near Santiago, C. W. Hayes, collector.

Polystomella sagra (d'Orbigny).

Rotalina sagra d'Orbigny, in De la Sagra, Hist. Fis. Pol. Nat. Cuba, "Foraminifères," p. 77, plate 5 , figs. 13 to 15,1839 .

A single specimen very exactly fitting the figure given by d'Orbigny was obtained in material from Bluff 2, Cercado de Mao, Santo Domingo. It was also found in the marl from station 3461, gorge of Yumuri River, Matanzas, Cuba, collected by T. W. Vaughan. It was also found in the Miocene material from Panama Canal Zone.

Polystomella lanieri d'Orbigny.

Polystomella lanieri d'Orbigny, in De la Sagra, Hist. Fis. Pol. Nat. Cuba, "Foraminifères," p. 54, plate 7, figs. $12,13,1839$.

Specimens showing very little variation and almost precisely like the figure given by d'Orbigny occur in both Zones $\mathrm{H}$ and I, Rio Cana, and Bluffs 2 and 3, Cercado de Mao, Santo Domingo. Brady, in the Challenger Report, places this species as a synonym of Polystomella crispa Linné, but these fossil specimens are very different from the typical $P$. crispa and are exactly like the figure of $P$. lanieri given by d'Orbigny. In fact, most of our specimens might have been taken for the illustration, so close are the essential details. It certainly seems that this is a valid species and one common in the Tertiary and perhaps the recent seas of the West Indies.

Very typical material was also obtained at station 3461, marl from gorge of Yumurí River, Matanzas, Cuba, collected by T. W. Vaughan.

Polystomella striatopunctata (Fichtel and Moll).

Polystomella striatopunctata (Fichtel and Moll), H. B. Brady, Rep. Voy. Challenger, Zoology, vol. 9 , p. 733 , plate 109, figs. $22,23,1884$.

Two specimens, rather more compressed and rounded in side view than usual, are here assigned to this rather overworked species. It has become the habit to place under this species almost any Polystomella which has short and simple depressions close to the suture. The specimens are from Bluff 3, Cercado de Mao, Santo Domingo.

\section{Heterostegina antillea, new species.}

(Plate 2, Figure 1, b; Plate 5, Figures 1, 2.)

The following is a description of this species:

Test compressed, unequally lenticular, umbo excentric, somewhat thicker than the remainder of the test, surface over the septal lines slightly raised in a series of somewhat papillate ribs, area between granular; chambers regularly curved, divided into numerous chamberlets.

Diameter up to $6 \mathrm{~mm}$. or more.

Type specimens from U. S. G. S. No. 6869, Long Island, Antigua. The vertical sections, plate 5 , figure 1 , which are probably the same 
species are from U.S. G.S. No. 6854, Rifle Butts, Antigua, and the horizontal section, plate 5 , figure 2 , from the same station. At this latter station the specimens are very numerous, making up a large proportion of the rock.

It may be noted here that the material under No. 6854 is of two kinds, as some of the hand specimens are made up almost entirely of Heterostegina and are of a slightly pinkish tinge, while others are white and are made up almost entirely of Lepidocyclina.

\section{Heterosteginoides antillea, new species.}

(Plate 5, Figures 5, 6.)

The following is a description of this species:

Test small, irregularly lenticular, surface somewhat papillate, in vertical section the central line of chambers slightly irregular, the lateral chambers piled in vertical rows in some specimens, in others variously placed.

Diameter 2 to $3 \mathrm{~mm}$. or more.

Type specimens (U. S. N. M. No. 328181) from U. S. G. S. No. 6965, lowest 10 to 15 feet of fossiliferous marls, southwest shore of Crocus Bay, Anguilla. At this station the species is very abundant, making up a large part of the rock. Specimens also are numerous at 6966 , same locality, 30 to 50 feet above sea-level, and at 6894, Anguilla.

This is more regular than its relative, $H$. panamensis Cushman, from the Canal Zone, although the figured specimen, plate 5, figure 6, is more than usually regular.

\section{Amphistegina lessonii d'Orbigny.}

(Plate 7, Figure 7.)

In the Bowden marl there are two distinct forms, possibly species, of Amphistegina. One of these is large, about $3 \mathrm{~mm}$. in diameter, thick, the lower side very granular, the sutures very obscure. The other is about half the diameter, flatter, both sides fairly smooth, a few granules about the aperture, the sutures very distinct. Both these forms are abundant in the Bowden marl of Jamaica.

\section{Amphistegina lessonii d'Orbigny, variety.}

Specimens of a very thin, biconvex form of this species, with the last-formed whorl making the entire surface of the test, that is completely involute, occur abundantly at Zone A, Rio Gurabo, Santo Domingo.

Amphistegina lessonii d'Orbigny, evolute variety.

A large evolute variety of Amphistegina is common at Zone I, Rio Cana, and both Bluffs 2 and 3, Cercado de Mao, Santo Domingo.

The status of the various species or varieties of Amphistegina is very unsatisfactory. They form a very common constituent of our Tertiary deposits and are often very decided and constant in their characters, especially in fossil material. 
Nummulities antillea, new species.

(Plate 4, Figures 1, 2.)

The following is a description of this species:

Test large, much compressed, only partially involute, the last coil broad and thin, surface with the suture lines raised, evenly curved, with a trace of papillate ornamentation along the ribs, peripheral margin somewhat thickened and rounded.

Diameter 15 to $18 \mathrm{~mm}$. or more.

Type specimens (U.S.N.M.No. 328182) from U.S.G.S. station 6924, from bed of limestone at top of described section, point on northwest side of St. Jean Bay, St. Bartholomew, collected by T. W. Vaughan. At this station specimens are abundant. The sectioned specimen, plate 4, figure 2, which seems to represent a young or the central portion of this species, is from U. S. G. S. No. 6895 , spur on southwest side of cay northwest of St. Jean Bay, St. Bartholomew, 170 feet above sea-level. It may be noted that Orthophragmina occurs at both of these stations, although not the same species. A few of the equatorial chambers of Orthophragmina, probably $O$. antillea, may be noted in the upper right-hand corner of figure 2.

This seems to be one of the larger of our American species of Nummulites.

\section{Nummulites parvula, new species.}

(Plate 4, Figures 3 to 6.)

The following is a description of this species:

Test small, closely involute, increase in breadth of test slight with each coil, sutures simple, slightly curved, test rather evenly lenticular, biconvex, chambers thick-walled, usually consisting of 4 or 5 coils.

Diameter up to $4 \mathrm{~mm}$.

Type specimen (U.S.N.M. No. 328183) from U.S.G.S. station 6903 , 220 feet above sea-level, N. $67^{\circ} \mathrm{E}$. from summit of Négre Point, across low saddleback of point, St. Bartholomew. The vertical sections may not represent this species, although they are very similar, but somewhat smaller. They are all from St. Bartholomew; plate 4, figures 4, 5, from U.S.G.S. No. 6924 , from bed of limestone top of section, point on northwest side of St. Jean Bay; figure 6 from 6921, point between Governor's Bay and Nigre Point.

\section{Nummulites species.}

In the Cuban material species of Nummulites occasionally occur, but are abundant at only one station. From station 3567, lowermost 100 feet of Tertiary running in above serpentine, northwest of Recreo, Matanzas Province, Cuba, collected by A. C. Spencer, Nummulites is very common, but the species have not been identified. This abundance with accompanying species of Orthophragmina and absence of Lepidocyclina would seem strongly to indicate the Eocene age of this particular material. 
Orthophragmina cubensis, new species.

(Plate 9, Figure 3; Plate 10, Figures 2 to 4.)

The following is a description of this species:

Test small, lenticular, circular, comparatively thick, thickness in the center greatest, about three-fifths the diameter, circular, gradually thinning toward the periphery, but without a definite border, periphery rounded; surface with numerous rather large papillæ in the center, gradually growing smaller toward the periphery.

Vertical sections showing the general shape of the test, which, due to the straightness of the slope from center to periphery, makes almost a diamondshaped vertical section; pillars of the center very heavy, thick, increasing rapidly in diameter toward the surface, the peripheral ends projecting above the adjacent lateral chambers; equatorial chambers of the same height, the band hardly increasing in diameter from center to periphery, very small; lateral chambers in vertical columns, up to 20 or more in a column in the thickest central portion, the individual chambers at least 4 or 5 times as wide as high in section.

Horizontal sections show the rectangular chambers of the equatorial region several times as long as wide, the lateral chambers forming an irregular network about the sections of the pillars, often several columns of vertical chambers between the pillars.

Diameter 1.5 to $3.5 \mathrm{~mm}$.

Type specimens (U.S.N.M. No. 328184) from station 3475, Boston mine, near Santiago, Cuba, collected by A. C. Spencer.

This seems to be a common Cuban species, occurring in material from several stations, as follows: 6117, boulder from the band of limestone, hill east of railroad and south of Cristo, near Santiago, Cuba, collected by C. W. Hayes, April 1901; 6118, limestone near railroad on trail to mines south of Cristo, collected by C. W. Hayes; 6119, Isabella and Boston manganese mine near Santiago, Cuba, collected by C. W. Hayes; 6120 , loose material, Santiago Province, Cuba, exact locality unknown; 6122, greensand limestone, Boston manganese mine, 3 miles east of Cristo, Santiago Province, Cuba, collected by A. C. Spencer; 6123, resting on ore-bed 4 to 6 feet thick, Ponupo manganese mine, Santiago Province, Cuba, collected by A. C. Spencer; 6124, foraminiferal limestone, Ponupo manganese mine, Ponupo, Santiago Province, Cuba, collected by R. T. Hill; 6125, railroad cut near San Nicolas manganese mine, west of San Luis, Santiago Province, Cuba, collected by C. W. Hayes; 3448, limestone from hillside south of Ponupo manganese mine, La Maya, near Santiago, Cuba, collected by T. W. Vaughan; 7666, from Sierra Guaso, northeast of Guantánamo, Cuba, collected by N. H. Darton, 1916.

The embryonic chambers of this species, so far as seen, are unequal in size and comparable to those seen in the subgenus Nephrolepidina of Lepidocyclina, the larger one kidney-shaped and partially embracing the smaller.

In its general characters this species suggests 0 . douvillei Schlumberger, but differs in several essential details. 
Orthophragmina crassa, new species.

(Plate 9, Figures 4 and 5; Plate 10, Figures 2 and 4.)

The following is a description of this species:

Test circular, lenticular, very thick in comparison to the diameter, central portion broadly convex, thence straight or even slightly concave to the rather acute periphery; surface fairly smooth, with a few raised ends of pillars making the surface slightly papillate.

Vertical section shows the general shape, in some specimens at least twothirds as thick as the diameter, central portion broadly rounded, with numerous large pillars, increasing in diameter toward the surface, lateral chambers very numerous, about three times as wide as high, usually at least 2 columns between each two adjacent pillars even in the center; over 30 chambers in the center in some of the columns are indicated; equatorial chambers increasing very slowly in height toward the periphery, but more rapidly than in most species, so that the equatorial band at the periphery may be double the width near the center; embryonic chamber comparatively large, elongate in this section.

Horizontal section shows the usual elongate, rectangular equatorial chambers; the pillars subpolygonal, largest in the center, thence smaller toward the periphery, intermediate lateral chambers irregularly polygonal.

Diameter 3.5 to $5.5 \mathrm{~mm}$.

Type specimen (U.S.N.M. No. 328185) from station 6122 , greensand limestone, Boston manganese mine, Santiago Province, Cuba, collected by A. C. Spencer. The species also appears to be present at the following stations: 6123, Ponupo manganese mine, resting on ore-bed 4 to 6 feet thick, Santiago Province, Cuba, collected by A. C. Spencer; 6124, foraminiferal limestone, Ponupo manganese mine, collected by R. T. Hill; 6125 , railroad cut near San Nicolas manganese mine, west of San Luis, Cuba, collected by C. W. Hayes; 6118, fossil limestone near railroad, on trail to mines south of Cristo, and 6119, Isabella and Boston manganese mine, Cuba, collected by C. W. Hayes; 3475 , Boston mine, near Santiago, Cuba, collected by A. C. Spencer; and apparently from 6117 , bowlder from the band of limestone, hill east of railroad and south of Cristo, near Santiago, Cuba, collected by C. W. Hayes.

\section{Orthophragmina subtaramellei, new species.}

(Plate 10, Figure 2; Plate 15, Figures 1 to 3.)

The following is a description of this species:

Test stellate, usually with 5 arms, occasionally 6 , arms well distinguished from the central body and extending outward freely; thickest in the central region, thence gradually sloping to the angles between the arms, and gradually merging into the median axis of the arms; the arms themselves thickest in the middle, thence sloping to the sides, which are thin and angled, ends of the arms round-pointed; surface with numerous granulations, more pronounced in the central portion.

Vertical sections show the general shape, the equatorial band of chambers increasing slightly if at all from the center to the periphery, pillars well developed, especially in the central region, but not numerous, usually several columns of lateral chambers between them.

Diameter 1.5 to $2 \mathrm{~mm}$. 
Type specimen (U. S. N. M. No. 328186) from Boston manganese mine, Santiago Province, Cuba. Besides the type station, according to the sections obtained, the species evidently also occurs at the following stations: 6119 , Isabella and Boston manganese mine, Santiago Province, Cuba, collected by C. W. Hayes; 6123, Ponupo manganese mine, Santiago Province, Cuba, resting or ore-bed 4 to 6 feet thick, collected by A. C. Spencer; 6124, foraminiferal limestone, Ponupo manganese mine, collected by T. R. Hill; 6125 , railroad cut near San Nicolas manganese mine, west of San Luis, Cuba, collected by C. W. Hayes; 3475 , Boston mine, near Santiago, Cuba, collected by A. C. Spencer; 7666, from Sierra Guaso, northeast of Guantánamo, Cuba, collected by N. H. Darton.

This species is very close to 0 . taramellei Munier-Chalmas, but is decidedly smaller, all the species seen from Cuba being less than $2 \mathrm{~mm}$. in diameter between the tips of the arms.

The specimens from station 6120 are weathered out and are numerous, greenish in color.

O. taramellei was described from Villa Lady Bruce (Biarritz); Monte Spilecco (Vicentin); Schönegg, near Kressenburg.

\section{Orthophragmina sculpturata, new species.}

(Plate 9, Figures 8, 9.)

The following is a description of this species:

Test circular, somewhat sellæform, often very slightly so; central portion considerably thickened and occupying one-third to one-fourth the diameter of the test; peripheral portion much flattened and comparatively thin; exterior of central thickened portion, when well preserved, beautifully sculptured, with comparatively few raised papillæ, between which the surface is depressed and reticulated as in 0 . marthe Schlumberger; peripheral thin portion of the test usually smooth when the surface is well preserved.

Vertical sections show thickening up to $1.5 \mathrm{~mm}$. in the central portion, while the periphery is often but $0.25 \mathrm{~mm}$. in thickness. Equatorial chambers small, increasing hardly at all in diameter from the center to the periphery, central embryonic chambers not well shown in the sections, but at least 6 to 8 times the diameter of adjacent equatorial chambers. Peripheral portion without pillars, central portion with very strong pillars, thick, with a diameter one-third to one-half their length and increasing very slightly in diameter toward the surface; lateral chambers in columns between the pillars very thin compared to their breadth. Central portion of the outline decidedly undulate from the projecting ends of the pillars.

Horizontal sections show very numerous equatorial chambers, elongate, several times as long as broad; lateral chambers in section appearing as polygonal lighter spaces surrounding in a single row the solid, opaque, circular, elliptical, or irregularly polygonal pillar sections, toward the periphery, where the pillars are wanting, forming an irregular network somewhat similar to the arrangement in 0. dispansa Sowerby (Bull. Soc. Geol. France, ser. 4, vol. 3, plate 12, fig. 51).

Diameter 5 to $7 \mathrm{~mm}$. 
Type specimen (U. S. N. M. No. 328187) from Nuevitas, Cuba, collected by A. C. Spencer.

This species in general appearance resembles 0 . marthce Schlumberger, especially in its characteristic surface ornamentation, but the vertical section seems to be very different from that figured by Schlumberger.

Orthophragmina pustulata, new species.

(Plate 9, Figures 6, 7; Plate 10, Figure 1.)

The following is a description of this species:

Test circular, lenticular, thickest in the middle, thence gradually thinning toward the periphery, which is without a carina or thinner portion, thickness about one-fifth the diameter; surface finely pustulose, papillæ larger and more numerous near the central region, thence gradually decreasing in size and number toward the periphery.

Vertical section shows the general form, equatorial band very thin, increasing hardly at all toward the periphery, pillars numerous, somewhat thickened toward the surface.

Horizontal section shows equatorial chambers elongate, rectangular, length about three times the breadth, annuli irregular in width, pillars irregularly rounded, remote, largest in center, decreasing gradually in size toward the periphery, intermediate space filled with the irregularly polygonal lateral chambers.

Diameter 3.5 to $5 \mathrm{~mm}$.

Type specimen (U.S. N. M. No. 328188), section from station 3567 , lowermost 100 feet of Tertiary running in above serpentine, northwest of Recreo, Matanzas Province, Cuba, collected by A. C. Spencer. Specimens, also apparently of this species, were obtained at station 3448 , limestone from hillside south of Ponupo manganese mine, La Maya, near Santiago, Cuba, collected by T. W. Vaughan.

This is a larger, flatter species than O. cubensis and is easily distinguished in the sections.

\section{Orthophragmina antillea, new species.}

(Plate 1, Figure 1; Plate 2, Figures 2 and 3; Plate 4, Figures 2 and 4.)

The following is a description of this species:

Test flattened, octagonal, surface with 8 raised ribs radiating from the central, somewhat raised umbo to the periphery, triangular areas between thin and flattened; umbonal area raised and rounded, with definite pillars appearing as differences in coloration in the type, radial ribs with numerous raised areas and pillars seattered along their whole length; diameter about $12 \mathrm{~mm}$.

Vertical sections show the greater diameter of the equatorial chambers at irregular intervals and the irregular, almost serrate character of the dorsal and ventral surfaces due to the fine projections of the surface, especially along the ribs.

Horizontal sections through the equatorial chambers were obtained only in small fragmentary bits, but enough to show the typical rectangular chambers of the genus. 
Type specimen (U.S. N. M. No. 328189) from St. Bartholomew, Leeward Islands, U.S. G. S. No. 6895, spur on southeast side of cay northwest of St. Jean Bay, 170 feet above sea-level; T. W. Vaughan collector.

Specimens are very numerous in this material; but a single specimen was obtained showing the surface conditions with the radiating ribs.

Although it is specifically different, this species is closely related to Orthophragmina mariannensis Cushman, from Marianna, Florida.

There appear to be from 5 to 8 layers of superimposed chambers at each side of the horizontal zone of chambers as shown in the sections. A few of the smallest specimens show the proloculum, but it is not well developed or not sufficiently well preserved to make out its characters clearly. The sections given on plate 2 , figures 2 and 3 , show the general characters of the vertical section.

Occasional oblique sections show the rectangular equatorial chambers characteristic of Orthophragmina.

This is the specimen mentioned by Vaughan as "Orbitoides sp., large, stellate form" (Vaughan, T. Wayland, Carnegie Inst. Wash. Year Book No. 13, p. 359, 1914).

\section{Orthophragmina marginata, new species.}

(Plate 1, Figure 2; Plate 2, Figure 4.)

The following is a description of this species:

Test lenticular, circular, central portion strongly raised and umbonate, regularly curved down to the broad peripheral flange, which is again thickened near the peripheral margin; surface comparatively smooth, very slightly granular, but not at all papillate.

In vertical section the central portion is seen to be strongly biconvex, but not much wider than either part of the surrounding margin-like thinner portion, again thickening toward the extreme peripheral margin, which is rounded.

Equatorial chambers small, in the center very narrow but increasing slightly but gradually toward the periphery, where they are not more than $0.1 \mathrm{~mm}$. in height. The chambers are convex on the peripheral side, almost semicircular in some specimens. Lateral chambers very small and often difficult to distinguish, even with an enlargement of 20 diameters (plate 2, fig. 4). In the central portion there are many layers of these lateral chambers, often 30 to 40 layers on either side of the equatorial band. This number decreases as the convexity becomes less, and over the flattened margin there are but 6 to 8 layers of lateral chambers. At the border this number is somewhat increased, but falls off again at the extreme outer margin. There are traces of pillars in the central umbonate region, but they are not prominent.

Diameter of the type specimen 12 to $14 \mathrm{~mm}$.

Type specimen (U.S. N. M. No. 328190) from St. Bartholomew, Leeward Islands; U. S. G. S. No. 6924, from a bed of limestone on point on the northwest side of St. Jean Bay; T. Wayland Vaughan collector. 
Lepidocyclina canellei Lemoine and Douvillé var. yurnagunensis, new variety.

(Plate 12, Figures 7, 8.)

The following is a description of this variety:

Test differing from the typical form of the species mainly in the form of the lateral chambers, which are somewhat broader, and with the upper wall decidedly arched; embryonic chambers either two, subequal or very unequal, or several, the equatorial chambers hexagonal or obscurely diamond-shaped.

Type material from U.S. G. S. station 7348, from flexure 2 miles south of Yurnaguna, Cuba, collected by O. E. Meinzer.

At this station the material is largely composed of this species, as the section (plate 12, fig. 8) shows. None of these sections happens to be exactly vertical. The variety shows the embryonic characters of all three of Douville's subgenera: equal chambers, as in the type from Panama (Isolepidina); unequal, one small, the other partially encircling and kidney-shaped (Nephrolepidina); and with two irregular large embryonic chambers and two or more small ones (Pliolepidina). The latter condition is shown in plate 12 , figure 7 .

In gross appearance, color, and general characters this material very strikingly resembles that from Bohio, Panama, the type locality for L. canellei.

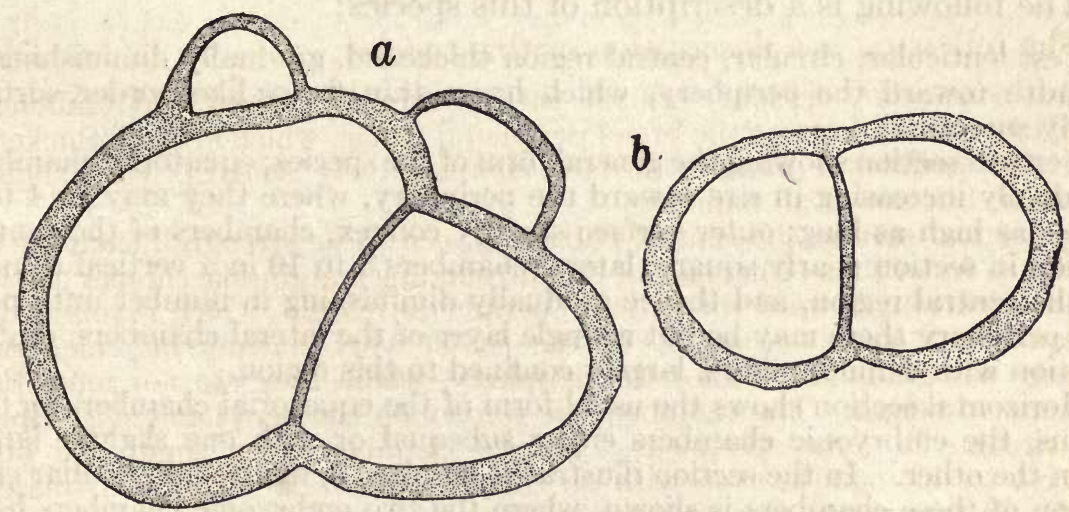

Fıg. 6.-Lepidocyclina canellei Lemoine and R. Douvillé var. yurnagunensis, new variety. $\times 50$. $a$, embryonic chambers, several in number and irregular in size (Pliolepidina). $b$, showing embryonic chambers of a specimen where these chambers are equal in size (Isolepidina). Specimens from station 7548, 2 miles south of Yurnaguna, Cuba.

Lepidocyclina schlumbergeri Lemoine and R. Douvillé.

Lepidocyclina schlumbergeri Lemoine and R. Douvillé, Soc. géol. France, Paléont., vol. 12, Mém. 32, p. 14, plate 1, fig. 10; plate 2, fig. 6; 1904 .

The following is a description of this species:

Test large, compressed, lenticular, thickest in the central region, from which it gradually thins out toward the periphery, somewhat flexuous and slightly saddle-shaped; surface fairly smooth or somewhat finely granular, the granules 
representing the ends of the small pillars; surface often uneven, due to the raised peripheral walls of the lateral chambers.

Vertical section shows the general shape, thin, gently curving from the center to the periphery, slightly curved; the pillars numerous and comparatively small, a very few larger pillars in the central region, vertical columns of lateral chambers with numerous low, flattened chambers making up each column.

Horizontal section shows hexagonal chambers, but more numerous equatorial ones with the outer wall convexly curved, walls rather thick.

Diameter 25 to $35 \mathrm{~mm}$.

Lemoine and Douville regard this as a mutation of L. dilatata. They record this species, especially from Spain at four localities in Andalusia, at Baèna, and Pont du Guadalquiver (Puente Viejo), and at Sella and Peñaguila, province of Alicante, stages not given. It was collected by O. E. Meinzer in Cuba at the following stations: 7512, Ocujal; 7518, south side near west end, Los Melones Mountain; 7522, Mogote Peak; 7543, limestone outcrop, east side of Yateras; and by N. H. Darton at 7664, north slope of La Piedra, northeast of Jamaica, northeast of Guantánamo.

\section{Lepidocyclina parvula, new species.}

(Plate 3, Figures 4 to 7.)

The following is a description of this species:

Test lenticular, circular, central region thickened, gradually diminishing in breadth toward the periphery, which has a thin flange-like border, surface fairly smooth.

Vertical section showing the general form of the species; equatorial chambers gradually increasing in size toward the periphery, where they may be 4 to 5 times as high as long; outer surface slightly convex, chambers of the central region in section nearly square; lateral chambers 8 to 10 in a vertical column in the central region, and thence gradually diminishing in number until near the periphery there may be but a single layer of the lateral chambers, central portion with definite pillars, largely confined to this region.

Horizontal section shows the usual form of the equatorial chambers for this genus, the embryonic chambers either subequal or with one slightly larger than the other. In the section illustrated on plate 3 , figure 4 , a peculiar condition of these chambers is shown, where the two embryonic chambers have a series of chambers, apparently coiled about them. This is an unusual character in this genus.

Diameter $5 \mathrm{~mm}$.

Type specimen (U. S. N. M. No. 328191) from U. S. G. S. station 6862, from lower bed at Hodge's Bluff, Antigua, T. W. Vaughan, collector. It is very abundant in material from certain layers at this locality. This species also occurs at station 6854, Rifle Butts, Antigua. 
Lepidocyclina morgani Lemoine and R. Douvillé.

(Plate 11, Figures 1 to 3; Text-fig. 7.)

Lepidocyclina cf. marginata H. Douville, Soc. Géol. France Bull., ser. 3, vol. 18, p. 1001, 1900. Lepidocyclina morgani Lemoine and R. Douvillé, Soc. Géol. France, Paléont., vol. 12, Mém. 32 , p. 17 , plate 1 , figs. $12,15,17$; plate 2 , figs. 4 , 12; plate 3 , fig. 2 ; 1904 .

The following is a description of this species:

Test small, discoidal, much thickened in the central portion, from which it tapers rather rapidly to the subacute periphery; central protuberant portion with a series of large pustules ranging from 5 to 12 or more in number, of which one is usually central, surface reticulate between the pustules; the margins stellate; periphery of the test thin and slightly reticulated by the walls of the equatorial chambers.

Vertical sections show the general form and curvature of the surface of the test, the few pillars in the central region rapidly increasing in diameter toward the surface of

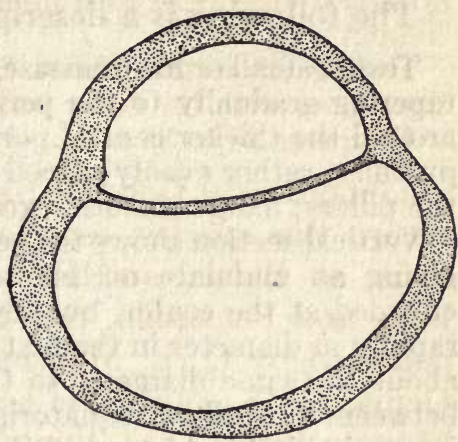

Fig. 7.-Lepidocyclina morgani Lemoine and R. Douvillé. Embryonic chambers. $\times 35$. Specimen from station 7543, limestone outcrop, east side of Yateras, Cuba.

the test; lateral chambers with the outer wall convex, averaging about three times as wide as high; in the central region with as many as 10 chambers in the vertical columns; equatorial chambers not increasing rapidly in height; height of those at the periphery not more than double that of those near the center.

Horizontal sections show the embryonic chambers, which are unequal, the larger one partially surrounding the smaller, as in the subgenus Nephrolepidina of $\mathrm{H}$. Douville and the equatorial chambers more or less diamond-shaped, as in that subgenus. In other specimens the outer wall of the chamber is convex.

Diameter 2 to $5 \mathrm{~mm}$.

Distribution.-Specimens seemingly identical with this species were found at the following stations in Cuba: 7513, limestone, outcrop where Palmer Trail joins Ocujal Trail; 7516, west end, Los Melones Mountain; 7543, limestone outcrop, east side of Yateras; 7554, south of El Jigue, 5 miles above mouth of Yateras River on west side, collected by $\mathrm{O}$. E. Meinzer. Specimens, the sections of which are imperfect, but probably belonging to $L$. morgani, were obtained by $\mathrm{O}$. E. Meinzer at station 7519, limestone from drift near top of landslide next north of Los Melones, and 7522, Mogote Peak. The specimens whose exteriors are figured were obtained by N. H. Darton at station 7664, north slope, La Piedra, northeast of Jamaica, northeast of Guantánamo, Cuba.

Lemoine and R. Douville record this species from four localities in Aquitaine (Abesse, Mimbaste, Saint-Etienne-d'Orthe, and Le Mandillot), from four localities in Spain (Baéna, Pont du Guadalquiver, Sella, and Peñaguila), and from Madagascar. The stage is indicated as Aquitanian but not definitely given.

It is a very distinctive species, and the Cuban specimens seem to differ in no essential characters from those figured by Lemoine and Douvillé. 


\section{Lepidocyclina marginata (Michelotti).}

(Plate 12, Figures 1, 2.)

Nummulites marginata Michelotti, Soc. Ital. Sci. Mem., vol. 22, p. 297, plate 3, fig. 4, 1841. Lepidocyclina marginata Lemoine and R. Douville, Soc. Géol. France, Palént., vol. 12, Mém. 32, p. 16, plate 1, fig. 7; plate 2, figs. 7,9 , 11, 20; plate 3 , figs. $3,8,9,13 ; 1904$.

The following is a description of this species:

Test of small or medium size, lenticular, thickest in the central region, thence tapering gradually to the periphery, which in the adult forms a thin flange around the thicker central portion; central portion with numerous prominent pustules, rather evenly placed and of good size, representing the outer end of the pillars; flange smooth, except for roughness caused by weathering.

Vertical section shows the general shape already noted, the numerous pillars giving an undulate outline to the central thickened region, pillars rather crowded at the center, but separating toward the periphery, increasing very rapidly in diameter in the first quarter or third of their length, thence keeping about the same diameter to the surface; lateral chambers in single columns between the pillars, equatorial band of chambers rather narrow and thin, increasing in height toward the periphery.

Horizontal section shows the equatorial chambers to be in general hexagonal, occasionally with the peripheral portion convexly curved; the lateral chambers also hexagonal, especially in the central region, where they are compressed by the pillars.

Diameter up to 12 or $15 \mathrm{~mm}$., usually less.

Distribution.-Lemoine and R. Douville record this species from Rosignano, Montferrat, Piémont, and Colli Torinesi, Turin, Italy, and from Pont du Guadalquiver and Baéna, Andalusia, Spain, stage not given. It was collected at the following stations in Cuba by $\mathrm{O}$. E. Meinzer: 7512, Ocujal; 7513 ?, orbitoidal limestone, outcrop where Palmer Trail joins Ocujal Trail; 7518, south side near west end, Los Melones Mountain; 7519, orbitoidal limestone, from drift near top of landslide next north of Los Melones; 7521, limestone, top of Mogote Peak; 7522 ?, Mogote Peak; 7543, limestone outcrop, east side of Yateras; and by N. H. Darton at station 7664, north slope of La Piedra, northeast of Jamaica, northeast of Guantánamo.

Lemoine and $\mathrm{R}$. Douville had only the microspheric form of the species, but the Cuban material has megalospheric specimens. The embryonic chambers are rather thick-walled and unequal in size.

\section{Lepidocyclina sumatrensis (H. B. Brady).}

(Plate 12, Figures 3, 4.)

Orbitoides sumatrensis H. B. Brady, Geol. Mag., ser. 2. vol. 2, p. 536, plate 14, fig. 3, 1875; Jaarb. Mijn. Ned.-Oost.-Indie, vol.7, pt. 2, p. 165, plate 2, fig. 3, 1878; Newton and Holland, Ann. Mag. Nat. Hist., ser. 7, vol. 3, p. 259, plate 10, figs. 7 to 12, 1899.

Lepidocyclina sumatrensis Jones and Chapman, in Andrews, A Monograph of Christmas Island, London, p. 244, plate 20, fig. 6, 1900; Newton and Holland, Journ. Coll. of Sci., Imp. Univ. Tokyo, vol. 27, art. 6, p. 11, plate 1, fig. 7, 1903; Lemoine and R. Douville, Soc. géol. France, Paléont., vol. 12, Mém. 32, p. 18, plate 1, fig. 14 ; plate 2 , fig. 15 ; plate 3 , fig. 6 ; 1904.

The following is a description of this species:

Test small, discoidal, thickened in the central portion, from which it tapers gradually to the subacute periphery, central protuberant portion more or less 
pustulate throughout, but these protuberant spots of small size and covering the larger part of the area more or less evenly; surface otherwise smooth; periphery thin.

Vertical sections show the general form and curvature of the test, pillars entirely lacking, lateral chambers with the outer surface convex, three or four times as wide as high; 6 to 10 chambers in a vertical column.

Horizontal sections show the embryonic chambers, which are unequal, the larger curved about the smaller semicircular one; equatorial chambers irregularly hexagonal.

Diameter 2 to $5 \mathrm{~mm}$.

Distribution.-L. sumatrensis was obtained in Cuba by O. E. Meinzer at the following stations: 7513, limestone outcrop where Palmer Trail joins Ocujal Trail; 7516, west end Los Melones Mountain; 7519, limestone from drift near top of landslide next north of Los Melones; 7543, limestone outcrop, east side of Yateras; 7554, south of El Jigue, 5 miles above mouth of Yateras River on west side; and by N. H. Darton at 7664, north slope of La Piedra, northeast of Jamaica, northeast of Guantánamo.

This species was described by Brady from Sumatra. It is recorded elsewhere in the East from Formosa and the East Indies, and Lemoine and $\mathrm{R}$. Douvillé record it from Rosignano, Montferrat, Piémont, Italy; Baéna, Pont du Guadalquiver, Peñaguila, and Sella, Spain; and Saint-Etienne-d'Orthe and Mandillot, near Dax, France, probably Aquitanian in age.

In the Cuban material it occurs usually in company with $L$. morgani, and in this connection it is interesting to note that both species are given by Lemoine and $R$. Douville from all four of the stations in Spain and from three of the four stations in France.

This species may easily be distinguished from $L$. morgani by its lack of pillars. The pustulate appearance of $L$. sumatrensis is due to the convex surface of the lateral chambers, those of adjacent columns being of unequal height at the surface.

\section{Lepidocyclina crassata, new species.}

(Plate 11, Figures 4, 5.)

The following is a description of this species:

Test of medium size, lenticular, comparatively thick in the center, thence tapering toward the sides; central portion convex, changing to a concave curve toward the periphery; surface irregularly pustulate, especially where somewhat weathered.

Vertical section shows the general shape, convex at the center and broadly rounded, thence thinning rapidly toward the periphery, where the surface is concave, to the rather poorly developed peripheral border; height or thickness of the test about one-third the diameter. Embryonic chamber large and very thick-walled, often showing 1 or 2 accessory chambers, also thick-walled and rather conspicuously perforate; young specimens show that for a time the embryonic chamber is the greater part of the test. Equatorial band of chambers rather large, even at the beginning, the outer wall convex and coarsely perforate. Lateral chambers comparatively thick-walled, several times as broad as high, somewhat lenticular in section, highest in the middle; thence 
their height decreases toward the sides. A comparatively small number of pillars in the central part originating in the wall of the embryonic chamber and extending to the periphery.

Horizontal section shows that the equatorial chambers are regularly hexagonal and fairly thick-walled, and that those of successive annuli are of very different sizes.

Diameter up to $9 \mathrm{~mm}$.; height up to $3 \mathrm{~mm}$. or more.
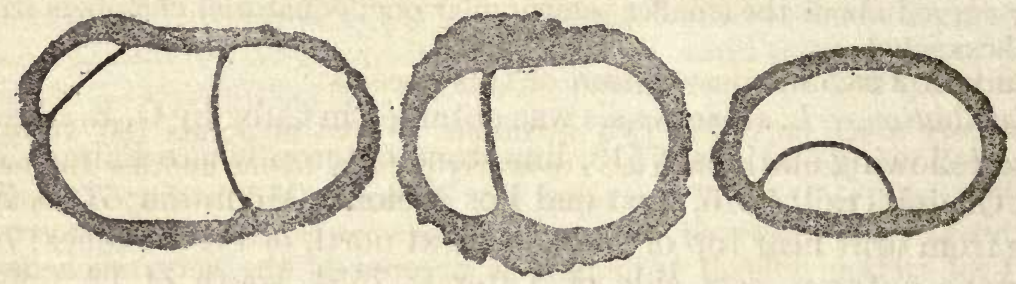

Fra. 8. - Sections of embryonic chambers of Lepidocyclina crassata, new species, showing variation in position of two or more divisions, and the comparatively thick outer wall. $\times 25$. Specimens from limestone from drift near top of landslide next north of Los Melones, Cuba.

Type specimen, section (U.S. N. M. No. 328192) from station 7513, orbitoidal limestone, outcrop where Palmer Trail joins Ocujal Trail, Cuba. Specimens are also numerous in material from 7512, Ocujal; 7519, orbitoidal limestone, from drift near top of landslide next north of Los Melones; 7521, limestone, top of Mogote Peak, Cuba. All the specimens were collected by $\mathrm{O}$. E. Meinzer.

$L$. crassata is very heavy and thick-walled and in section may be easily distinguished from any other Cuban or West Indian species of Lepidocyclina.

\section{Lepidocyclina subraulinii, new species.}

(Plate 11, Figures 6, 7; Plate 12, Figures 5, 6.)

The following is a description of this species:

Test circular, much thickened in the central portion, which occupies about one-third the diameter of the test; peripheral portion much flattened, thin; thick central portion irregularly papillate, peripheral portion smooth, showing almost no tendency to become saddle-shaped.

Vertical section shows the general thickness, the central lenticular body, and the thin periphery; central portion with very numerous pillars, increasing in diameter toward the surface; lateral chambers crowded between the pillars, very numerous in the vertical columns and much wider than high; equatorial chambers increasing in diameter toward the periphery, the outer margin convex and with a series of fine pores.

Horizontal section shows the equatorial chambers, which are polygonal; the outer margin strongly convex; pillars subpolygonal, with the lateral chambers making irregular polygonal meshes between them, toward the periphery the lateral chambers making up the entire test as the pillars decrease in number.

Diameter up to $24 \mathrm{~mm}$.; thickness in center $4.5 \mathrm{~mm}$.

Type specimen (U. S. N. M. No. 328193) from station 3478 , Nuevitas, Cuba, collected by A. C. Spencer. Other specimens apparently this species occur at 7666, Sierra Guaso, northeast of Guantánamo, collected by N. H. Darton. 
In diameter and general shape $L$. subraulinii suggests $L$. raulinii Lemoine and R. Douvillé from Saint-Géours-en-Maremmes, Landes, France, and Columbres, Province of Santander in Spain, but it differs in that it has very definite pillars and a papillose surface at the center. The age of the European material of $L$. raulinii is not definitely given.

Lepidocyclina perundosa, new species.

(Plate 11, Figure 8.)

The following is a description of this species:

Test very much curved in two directions, so that at points $180^{\circ}$ from one another the two planes of each set are nearly parallel to one another and nearly at right angles to those of the other set, strongly "saddle-shaped," surface smooth when well preserved, but usually somewhat cancellate, due to erosion.

Vertical section difficult to obtain on account of the very much doubly curved shape of the test, but shows no pillars; the lateral chambers about three times as long as high; central chamber large; equatorial chambers increasing gradually in size toward the periphery, their height and breadth about equal.

Horizontal section, which from the shape of the test can be at best only fragmentary, shows equatorial chambers roughly triangular, with the outer surface convexly curved.

Diameter 8 to $12 \mathrm{~mm}$.

Type specimen, section (U. S. N. M. No. 328194), from station 3478 , Nuevitas, Cuba, collected by A. C. Spencer.

This is a very sellæform species about one-half the size of $L$. undosa Cushman from Antigua.

\section{Lepidocyclina antillea, new species.}

(Plate 3, Figure 3.)

The following is a description of this species:

Test compressed, circular, rather evenly biconvex, lenticular, central portion highest, thence gradually thinning toward the periphery, central area strongly papillate, remainder of surface less strongly so.

Vertical section shows equatorial chambers gradually increasing in height toward the periphery, those of the central region measuring less than $0.1 \mathrm{~mm}$., those of the periphery as much as $0.5 \mathrm{~mm}$. in height; outer wall of the equatorial chambers very squarely truncated.

Lateral chambers not numerous in the central thickened region, with only 6 or 7 chambers in a column, and this number is gradually reduced toward the periphery. Central region and the whole test in lesser degree marked by very heavy and numerous pillars, greatest width near the outer end, thence gradually tapering toward the center, outer ends rounded, forming the papillæ of the surface. In the central region the surface area occupied by the pillars is greater than that taken up by the lateral chambers.

In the horizontal section, or at least in the somewhat broadly oblique section, the equatorial chambers are of the curved Lepidocyclina form instead of the more typical hexagonal shape.

Diameter of the test averages about $5 \mathrm{~mm}$.

Type specimen (U. S. N. M. No. 328195) from U. S. G. S. No. 6897, from St. Bartholomew, Leeward Islands, from conglomerate and sand- 
stone below upper limestone bed, Anse Ecaille side of point between Anse Ecaille and Anse Lizard; T. W. Vaughan, collector; specimens apparently weathered out from the matrix are abundant. Also from $6897 b$, point between Colombier Point and bay next to St. Jean Bay. Hand specimens showing sections of this heavy-pillared species are abundant in a hard cherty material, No. 6902, southeast section of southwest side of island near Négre Point, altitude 360 feet; and 6903, N. $67^{\circ}$ E. from summit of Négre Point, across low saddle-back of point, elevation 220 feet. All the above are from St. Bartholomew.

This species is related in many ways to Lepidocyclina macdonaldi Cushman from Panama, in the white limestone at David. The general vertical section is much more heavily pillared in $L$. antillea, although the figured specimen, not being exactly central, shows this much less strongly than in many of the weathered sections in hand specimens.

\section{Lepidocyclina gigas, new species.}

(Plate 1, Figures 3 to 5; Plate 5, Figure 4.)

The following is a description of this species:

Test large, flattened, somewhat lenticular, circular in outline, central portion slightly umbonate, thence gradually thinning toward the periphery, which is bluntly angular; surface generally flat and smooth, occasionally slightly undulating.

Vertical section shows the equatorial chambers increasing somewhat in height from the central area toward the periphery, the peripheral end of each chamber slightly convex toward the exterior; lateral chambers broad and low, in vertical columns, usually from 7 to 10 chambers in each column in the central portion of the test outside the umbonal region, thence gradually decreasing in number toward the periphery. There are pillars developed at irregular intervals, but these are few in number and of very small diameter.

Horizontal sections show the hexagonal equatorial chambers, the annular rows of which are very uneven in size.

Diameter of largest specimens up to $80 \mathrm{~mm}$. or more.

Type specimen (U.S. N.M. No. 328196) from Antigua, Leeward Islands, U. S. G. S. No. 6862, from lower bed at Hodge's Bluff; T. W. Vaughan, collector. Specimens from this locality are numerous and very fine. Poorer material, but apparently specifically the same, occurs at 6854 , Rifle Butts, and 6857, southwest side of Wetherell Mill, both from Antigua.

This species is very near to L. elephantina Munier-Chalmas, but the two early chambers in the two species do not seem to be at all alike, those of $L$. elephantina being very dissimilar in size and shape, while those of $L$. gigas, as far as made out, seem to be much more nearly equal, as is usual in American species of Lepidocyclina.

This is a very fine, large species, abundant at the type station. 
Lepidocyclina undulata, new species.

(Plate 3, Figures 1a, 2, 8, 9; Plate 15, Figure 5.)

The following is a description of this species:

Test of large size, slightly papillate, lenticular, the umbonate region scarcely if at all raised, whole test undulate or saddle-shaped, often bent nearly double.

Vertical sections of this species show pillars very constant but of small diameter scattered throughout the central half of the test and a few toward the peripheral portion; equatorial chambers fairly high and with a series of 6 to 8 rather large perforations in the peripheral wall of each; lateral chambers thick-walled and rather large, comparatively few, usually not more than 6 in a vertical column.

Diameter in the largest specimens apparently exceeding $100 \mathrm{~mm}$. when complete.

Type specimen (U.S. N.M. No. 328197) from Antigua, Leeward Islands, U. S. G. S. No. 6863, High Point, collected by T. W Vaughan. Specimens are abundant at this station. Other material from Antigua apparently referable to this species is from No. 6858, Wetherell Point; 6874, Blizzard's Mill; (?) 6880, west side Otto's estate, west side of Golden Grove road; 6881, from bluffs on north side of Willoughby Bay; and 6942, bowlders on south side of Monk's Hill, Falmouth.

This seems to be the largest known species of Lepidocyclina, being larger than $L$. elephantina. The material here figured (plate 3, figs. 1, 2; plate 14, fig. 5) from 6869 and 6881 are for the most part composed of other species, but a few large specimens apparently referable to this are shown with the others.

\section{Lepidocyclina undosa, new species.}

(Plate 2, Figure 1, a.)

The following is a description of this species:

Test of medium size, much compressed, strongly undulate or saddle-shaped, not at all umbonate, thin throughout, surface slightly granulate, otherwise smooth, where worn usually netted by the walls of the chambers.

Vertical section showing apparently an entire absence of pillars throughout, equatorial chambers nearly square in section, walls straight, lateral chambers very numerous, low and broad, very thin-walled, 12 to 15 in a vertical column in the thicker portions of the test.

Horizontal sections showing typical hexagonal equatorial chambers.

Diameter up to $25 \mathrm{~mm}$. or more.

Type material (U.S. N.M. No. 328198) from Antigua, Leeward Islands, U. S. G. S. No. 6869, Long Island, Antigua. The species is very abundant in this material, making up a large proportion of the rock-mass. Specimens are associated with Heterostegina.

This may be distinguished from other species of Lepidocyclina by its saddle-shaped test, the flat, non-umbonate center, the finely netted surface in worn specimens, and the absence of pillars in the vertical section with the thin-walled chambers. 
Lepidocyclina farosa, new species.

(Plate 3, Figures 1, 2, b; Plate 15, Figure 4.)

The following is a description of this species:

Test of medium size, compressed, strongly undulate or saddle-shaped, the central portion umbonate, much curved, thick; the remainder of the test thin and flange-like; central umbonate mass with an ornamentation of polygonal areas formed by raised ribs; remainder of test fairly smooth but irregularly eroded in most cases.

Vertical section with numerous distinct pillars in the umbonate region, broad at the exterior and narrowing to a point near the equatorial chambers, flattened peripheral portion with few indistinct pillars.

Diameter 15 to $18 \mathrm{~mm}$. for typical specimens.

Type specimens (U.S. N. M. No. 328199) from Antigua, Leeward Islands, U. S. G. S. No. 6881 , from bluffs on north side of Willoughby Bay.

This is a very strikingly ornamented species and hardly likely to be mistaken for any other, especially with its very strong saddleshape in addition. It was not seen in any material from the other Antigua stations, but is very abundant at this station, as the photograph (plate 3, fig. 1) will show.

\section{MIIIOLIDE.}

Spiroloculina species (?).

(Plate 5, Figures 9 and 12.)

A section showing longitudinally a specimen of Spirolculina and an oblique section of a similar specimen are reproduced on plate 5, figure 9. This is from U. S. G. S. No. 6949, Simson Bay Point, St. Martin, Leeward Islands. In this material, in which specimens of Orbitolites are abundant, specimens of Spiroloculina are frequent, but as they show only in section, it is not possible accurately to determine them specifically. In a section from U. S. G. S. No. 6966, southwest shore of Crocus Bay, Anguilla, there is a transverse section of a Spiroloculina with convex periphery and concave faces (plate 5, fig. 12), but whether it is the same species as that from St. Martin is problematical. The associated species at each locality are very different, however, as the abundant genus in St. Martin is Orbitolites, while in Anguilla it is Heterosteginoides.

\section{Quinqueloculina agglutinans d'Orbigny.}

Quinqueloculina agglutinans d'Orbigny, in De la Sagra, Hist. Fis. Pol. Nat. Cuba, "Foraminifères," p. 195, plate 12 , figs. 11 to 13,1839 .

Occasional very typical specimens occur at Zone H, Rio Cana, and at Bluffs 2 znd 3, Cercado de Mao, Santo Domingo. It may be noted that these specimens are almost exactly like the figures given by d'Orbigny rather than those of recent material given by later authors. 
Quinqueloculina cuvieriana d'Orbigny.

Quinqueloculina cuvieriana d'Orbigny, in De la Sagra, Hist. Fis. Pol. Nat. Cuba, "Foraminifères," p. 190, plate 11, figs, 19 to $21,1839$.

A few specimens with the typical ornamentation of the species occurred at Zone I, Rio Cana, and Bluff 2, Cercado de Mao, Santo Domingo. These are almost exactly like the Cuban monograph figures, but very different from the figures assigned to this species by later authors.

\section{Quinqueloculina auberiana d'Orbigny.}

Quinqueloculina auberiana d'Orbigny, in De la Sagra, Hist. Fis. Pol. Nat. Cuba, "Foraminifères," p. 193, plate 12 , figs. 1 to 3,1839 .

Very typical specimens occur in material from Zone H, Rio Cana, and Bluffs 2 and 3, Cercado de Mao, Santo Domingo. These are more closely like the original figures of the type than of later figures of other authors.

Specimens are rare in the Bowden marl of Jamaica, but are very typical, like the Santo Domingo specimens, and like the original figures given by d'Orbigny in his Cuba monograph.

Typical specimens also occur in the Miocene of the Panama Canal Zone and Virginia.

\section{Quinqueloculina pulchella d'Orbigny.}

Miliolina pulchella (d'Orbigny) H. B. Brady, Rep. Voy. Challenger, Zoology, vol. 9, p. 174, plate 6 , figs. $13,14,1884$.

A few specimens with characteristic ornamentations occur at Zones $\mathrm{H}$ and I, Rio Cana, and Bluffs 2 and 3, Cercado de Mao, Santo Domingo.

\section{Quinqueloculina gualteriana d'Orbigny.}

Quinqueloculina gualteriana d'Orbigny, in De la Sagra, Hist. Fis. Pol. Nat. Cuba, "Foraminifères," p. 186, plate 11 , figs. 1 to 3,1839 .

Specimens seemingly identical with this species as figured by d'Orbigny occur at Zones $\mathrm{H}$ and I, Rio Cana, and there are questionable specimens from Bluff 3, Cercado de Mao, Santo Domingo; but they are rare, two being the most from any one station.

\section{Quinqueloculina species cf. Q. kerimbatica (Heron-Allen and Earland).}

(Plate 13, Figure 5.)

Miliolina kerimbatica Heron-Allen and Earland, Trans. Zool. Soc. London, vol. 20, p. 574, plate 43 , figs. 13 to 23,1915 .

Large specimens seemingly identical with the recent species described by Heron-Allen and Earland from the Kerimba Archipelago off the southeastern coast of Africa occur both at Bluffs 2 and 3, Cercado de Mao, Santo Domingo. In their size, shape, and peculiar type of coarse, irregularly reticulate ornamentation these fossil specimens are strikingly like the recent African-Indian Ocean specimens. The same 
species occurs abundantly in the recent Philippine material, and Millett records it from the Malay Archipelago under the name Miliolina parkeri. This is a rather interesting distribution, corresponding somewhat with what Vaughan has shown for some genera of corals now extinct in the West Indies, but found living in the Indo Pacific.

Quinqueloculina parkeri (H. B. Brady) var. bowdenensis, new variety.

(Plate 14, Figure 6.)

The following is a description of this variety:

Variety differing from the typical mainly in the reduced amount of the ornamentation, which in the variety consists of several short obliquely transverse ridges confined to the periphery of the test, which is bluntly angled.

Length $0.5 \mathrm{~mm}$.

Type specimen (U.S. N. M. No. 328200) from the Miocene Bowden marl, Jamaica.

The typical form of the species is known from the East Indian region and the Red Sea.

$$
\text { Quinqueloculina species (?). }
$$

(Plate 5, Figure 8.)

A single section of a portion of a specimen of Quinqueloculina was noted in a section from U. S. G. S. No. 6966, southwest shore of Crocus Bay, Anguilla, 30 to 50 feet above sea-level. From what is present this is apparently a smooth, angular species, but nothing further can be made of its specific determination.

\section{Triloculina tricarinata d'Orbigny.}

(Plate 14, Figure 4.)

Triloculina tricarinata d'Orbigny, Ann. Sci. Nat., vol. 7, p. 299, 1826.

Miliolina tricarinata H. B. Brady, Rep. Voy. Challenger, Zoology, vol. 9, p. 165, plate 3 , figs. $17 a, b, 1884$.

A single specimen of this tricarinate species was found in the Bowden marl from Bowden, Jamaica. It is not sharply carinate, but the aperture is very characteristic.

\section{Triloculina brongniartiana d'Orbigny.}

Triloculina brongniartiana d'Orbigny, in De la Sagra, Hist. Fis. Pol. Nat. Cuba, "Foraminifères," p. 176, plate 10, figs. 6 to 8,1839 .

A few finely striate specimens from the Bowden marl, Bowden, Jamaica, are very similar to the figures of this species given by d'Orbigny from Cuba. In the Challenger Report, Brady refers this species with a question to the later name T. boueana of d'Orbigny, but the two seem to be distinct and the fossil specimens under consideration are certainly very close to $T$. brongniartiana. Brady's reference to their 
being "young examples, in a Triloculine condition" is erroneous, as the young of Triloculina is quinqueloculine in the microspheric form at least, while the young of Quinqueloculina is quinqueloculine in both forms, microspheric and megalospheric. Our specimens, too, are larger than those figured by Brady as $T$. boueana.

Triloculina fichteliana d'Orbigny.

Triloculina fichteliana d'Orbigny, in De la Sagra, Hist. Fis. Pol. Nat. Cuba, "Foraminifères," p. 171 , plate 9 , figs. 8 to 10,1839 .

A single specimen referred to this species was found in the material from Bluff 3, Cercado de Mao, Santo Domingo.

Biloculina species.

Two small specimens of Biloculina were found in the material from Bluff 3, Cercado de Mao, but are not in condition to identify them specifically. A single small specimen was also found in marl from station 3461, gorge of Yumurí River, Matanzas, Cuba, collected by T. W. Vaughan. Specimens referred to B. bulloides d'Orbigny were obtained from the Miocene of the Panama Canal Zone and from Florida.

\section{Vertebralina cassis d'Orbigny.}

Vertebralina cassis d'Orbigny, in De la Sagra, Hist. Fis. Pol. Nat. Cuba, "Foraminifères," p. 51 , plate 7 , figs. 14, 15, 1839 .

From the material from Zone H, Rio Cana, Santo Domingo, a single specimen was obtained. It is of the form figured by d'Orbigny as $V$. cassis and has the typical ornamentation, although somewhat eroded.

\section{Vertebralina striata d'Orbigny.}

(Plate 14, Figure 3.)

Jones and Parker record this species in their list of Foraminifera from the Bowden marl, Jamaica. I have found a single specimen in my material, figured here.

\section{Peneroplis pertusus Forskål var. discoideus Flint.}

Peneroplis pertusus var. discoideus Flint, Ann. Rep. U. S. Nat. Mus., 1897, p. 304, plate 49, figs. 1, 2, 1899.

These specimens from Bluff 3, Cercado de Mao, Santo Domingo, are identical with this peculiar variety described by Flint from the shallow water of Key West Harbor, Florida.

\section{Peneroplis pertusus Forskål variety.}

A single specimen from Bluff 3, Cercado de Mao, has the typical form of Orbiculina adunca, but, as the chambers throughout seem to be undivided, the specimen is a true Peneroplis. 


\section{Orbiculina adunca (Fichtel and Moll).}

Orbiculina adunca (Fichtel and Moll) d'Orbigny in De la Sagra, Hist. Fis. Pol. Nat. Cuba,

"Foraminifères," p. 64, plate 8 , figs. 8 to 16,1839 .

Specimens of this common West Indian species occur at Zones $\mathrm{H}$ and I, Rio Cana, and Bluffs 2 and 3, Cercado de Mao, Santo Domingo.

\section{Orbiculina compressa d'Orbigny.}

(Plate 7, Figure 6.)

Orbiculina compressa d'Orbigny, in De la Sagra, Hist. Fis. Pol. Nat. Cuba, "Foraminifères," p. 66, plate 8, figs. 4 to 7, 1839; Jones, Parker, and H. B. Brady, Crag Foram., Pal. Soc., vol. 19, p. 21, plate 3, fig. 43, 1866 ; Hill, Bull. Mus. Comp. Zoöl., vol. 34, p. $147,1899$.

The following is a description of this species:

Test flattened, circular or elliptical in outline, early chambers spiral, soon extending back to make a crosier-formed test, after which by further elongations the chamber ends meet and form annuli; wall calcareous, smooth, apertures circular openings about the peripheral wall.

Diameter up to $3 \mathrm{~mm}$.

This species is not uncommon in the Bowden material from Jamaica, but is frequently broken, due to the thin, entirely calcareous test and the weakness that easily develops along the sutural lines. In Hill's list of the species identified by Doctor Bagg both O. compressa and $O$. adunca are given. Among the specimens I have seen there is none that is the typical thick form of $O$. adunca; but all are thin, flattened, and develop annuli very early, and, therefore, are typical 0 . compressa.

\section{Orbitolites (Sorites) duplex Carpenter.}

(Plate 5, Figures 9, 10.)

The material from U.S. G.S. No. 6949, Simson Bay Point, St. Martin, numerous specimens of a medium-sized Orbitolites. Vertical sections of material from this station are shown on plate 5, figure 9 . As a rule the specimens are much like 0 . duplex in section. According to Douville, current conceptions of Orbitolites need much revision. The true Orbitolites, with 0 . complanata as the type, from the Eocene of the Paris Basin, seems to be not found living at the present time. A portion of a horizontal section from U. S. G. S. No. 6894 , southwest side of Crocus Bay, Anguilla, shows a few chambers in which the connections between the adjacent chambers seem much more like those in Sorites Ehrenberg, which, according to Douville, includes the recent species 0 . marginata and 0 . duplex. The fossil Orbitolites need a careful revision from a study of carefully sectioned material.

Specimens very similar to the above occur at the following stations in Cuba, collected by T. W. Vaughan: 3440, northeast part of Santiago, in marl on hillside; 3443 , northeast part of Santiago, marl at foot of hills, and 3446, first deep cutting on railroad east of La Cruz, near Santiago. 
Orbitolites complanata (Lamarck) variety.

Orbitolites complanata (Lamarck) H. B. Brady, Rep. Voy. Challenger, Zoology, vol. 9, p. 218, plate 16, fig. 1, 1884.

The form of $O$. complanata, very abundant in a fine sandy material from Bluff 3, Cercado de Mao, Santo Domingo, differs from the ordinary form of this species in being thinner, more like 0 . duplex, but with the multiple chambers of $O$. complanata; the apertures, however, occur in a very narrow band along the center of the peripheral face. These characters are very constant.

\section{Alveolina species (?).}

(Plate 5, Figure 14.)

A single specimen, apparently a longitudinal section of Alveolina occurs in sectioned material from U.S.G.S. No. 6949, Simson Bay Point, St. Martin, Leeward Islands. It occurs with abundant Orbitolites. 


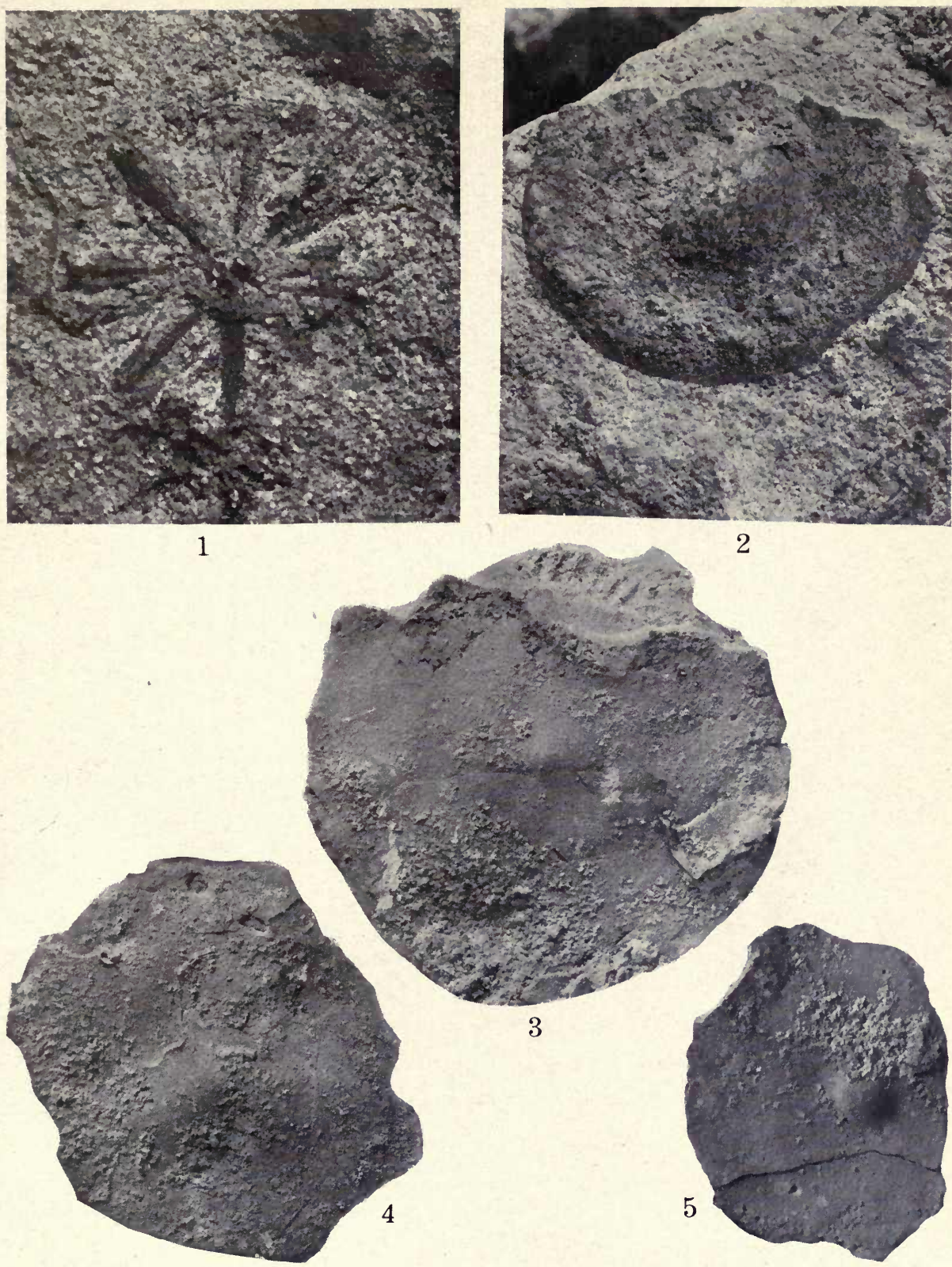

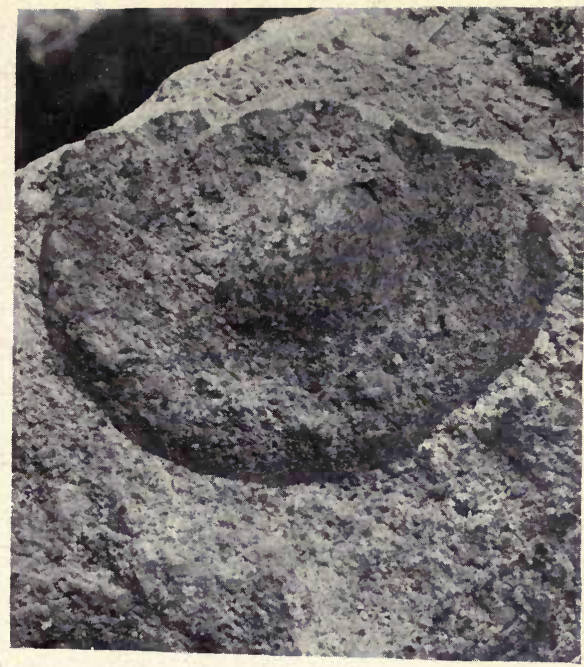




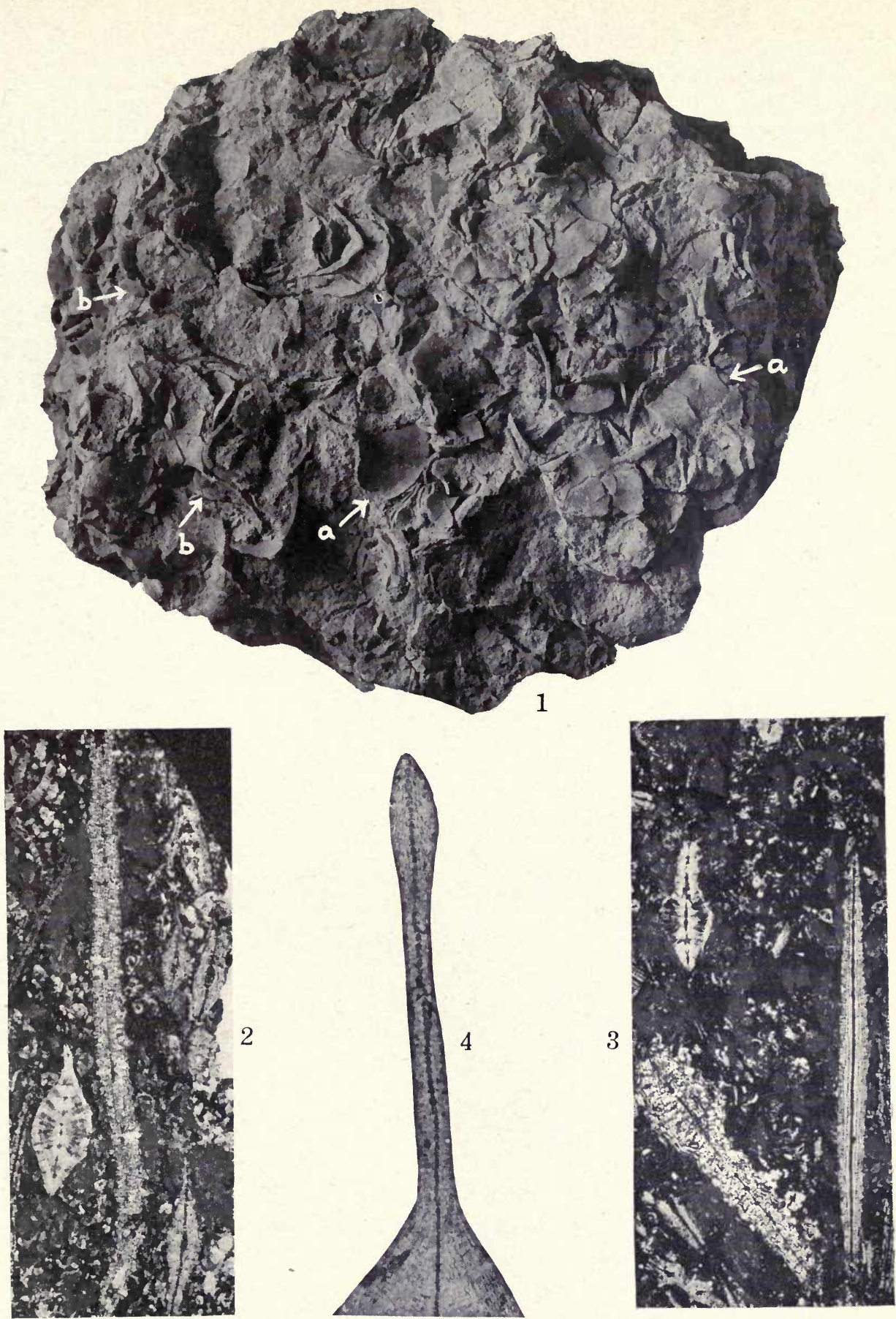

1. Rock specimen, 0.8 natural size, made up largely of (a) Lepidocyclina undosa, n. sp., and (b) Heterostegina antillea, n. sp.

2 and 3. Vertical sections of Orthophragmina antillea, n. sp. $\quad \times 16$

4. Vertical section of part of central umbonal portion and peripheral flange and thickened periphery of Orthophragmina marginata, n. sp. $\times 16$. 


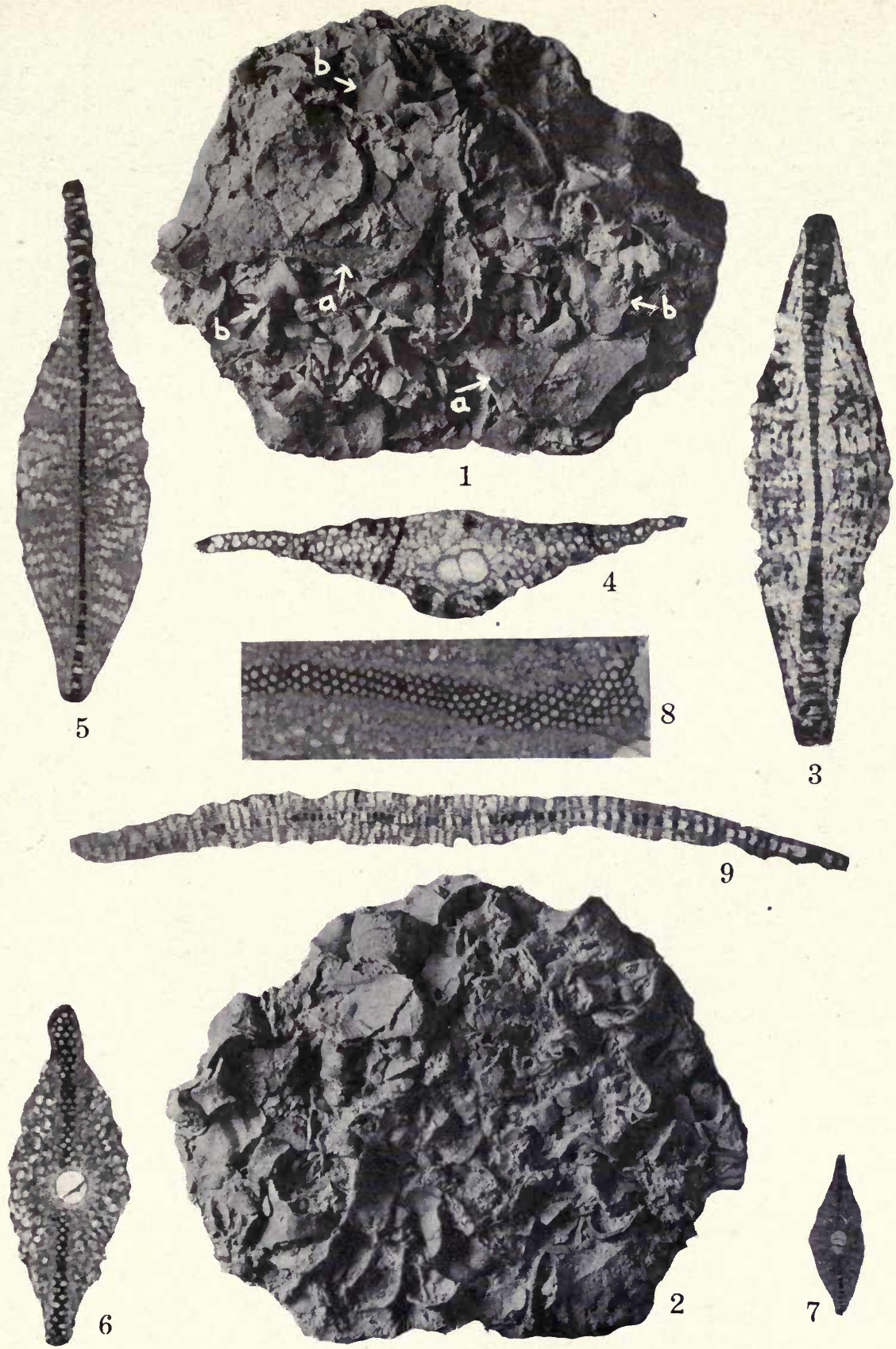

1, Rock specimen, 0.75 natural size, made up largely of (a) Lepidocyclina undulata, n. sp., (b) L. favosa, n. sp.

2. Reverse of specimen shown in fig. 1 .

3. Lepidocyclina antillea, n. sp. Vertical section. $\times 15$.

4. Lepidocyclina parvula, n. sp. Section somewhat oblique, showing two slightly unequal early chambers, with few chambers following a trace of a spiral arrangement. $\quad \times 15$.

$5,6,7$. Lepidocyclina parvula, n. sp. Vertical o1 slightly oblique sections showing equatorial and lateral chambers. Figs. 5 and $6, \times 15$; fig. $7, \times 7.5$.

8. Lepidocyclina undulata, n. sp. Por tion of horizontal section. $\times 7.5$.

9. Lepidocyclina undulata, n. sp. Portion of vertical section. $\times 7.5$. 



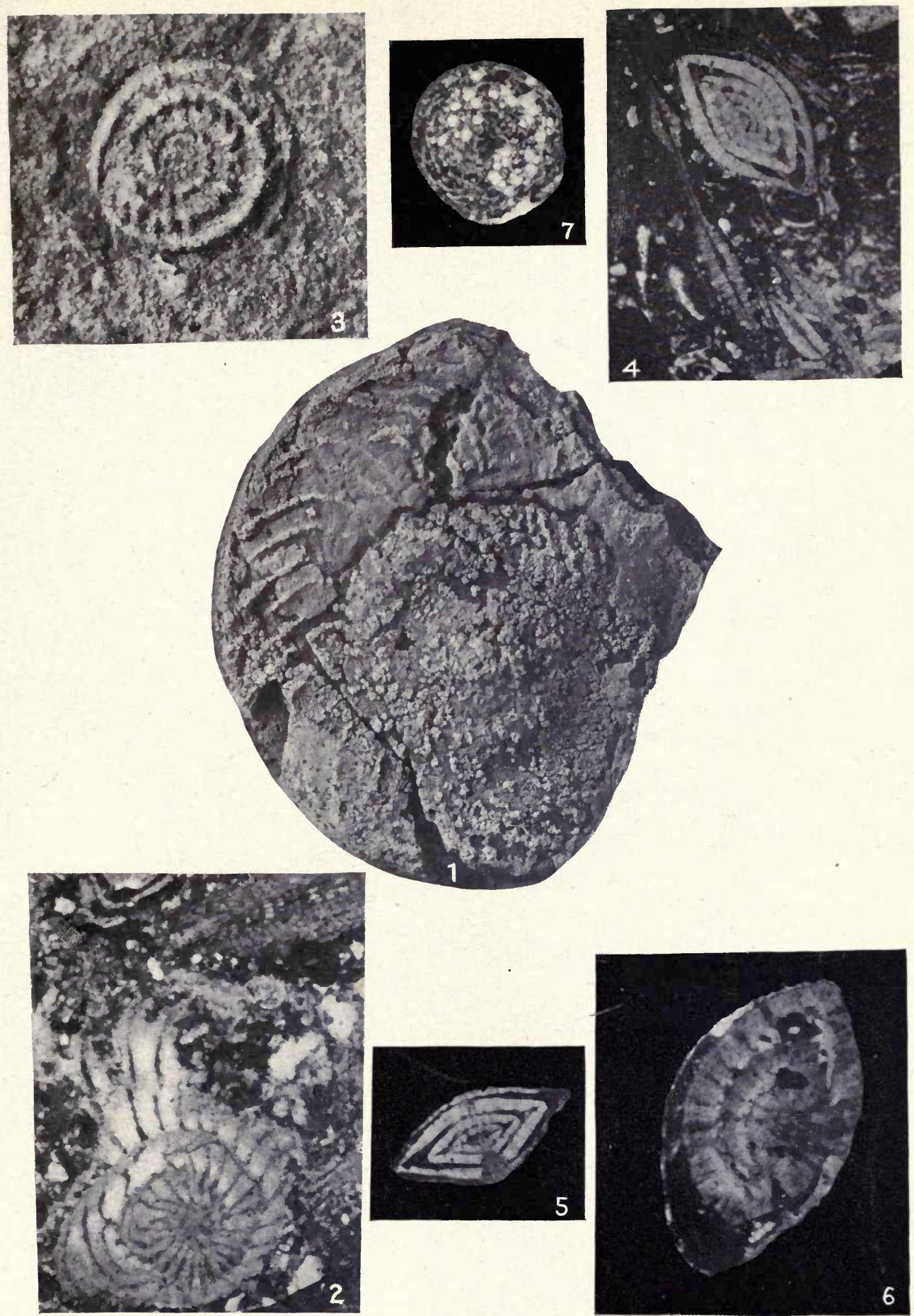

1. Nummulites antillea, n. sp. Photograph of type specimen. $\times 5$. Specimen somewhat eroded, showing traces of chamber walls.

2. Section of portion on N. antillea, n. sp. $\times 20$. At upper right hand are few equatorial chambers of Orthophragmina antillea, n. sp.

3. Nummulites parvula, n. sp. Accidental weathered specimen. $\times 8$.

4,5 , and 6. Vertical section of $N$. parvula, n. sp. $\times 20$. Figure 4 also shows a vertical section of a portion of Orthophragmina antillea, n. sp., through two radial ribs.

7. Gypsina globulus, Reuss. Transverse section. $\times 20$. 



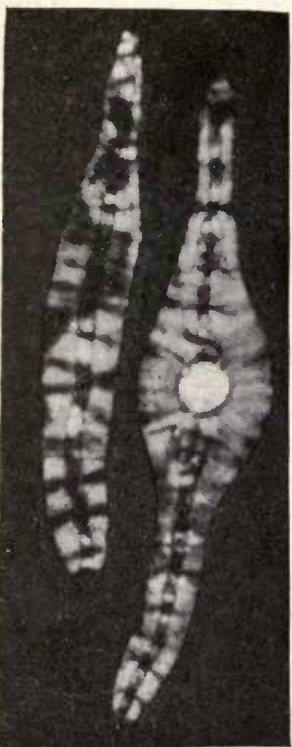

1
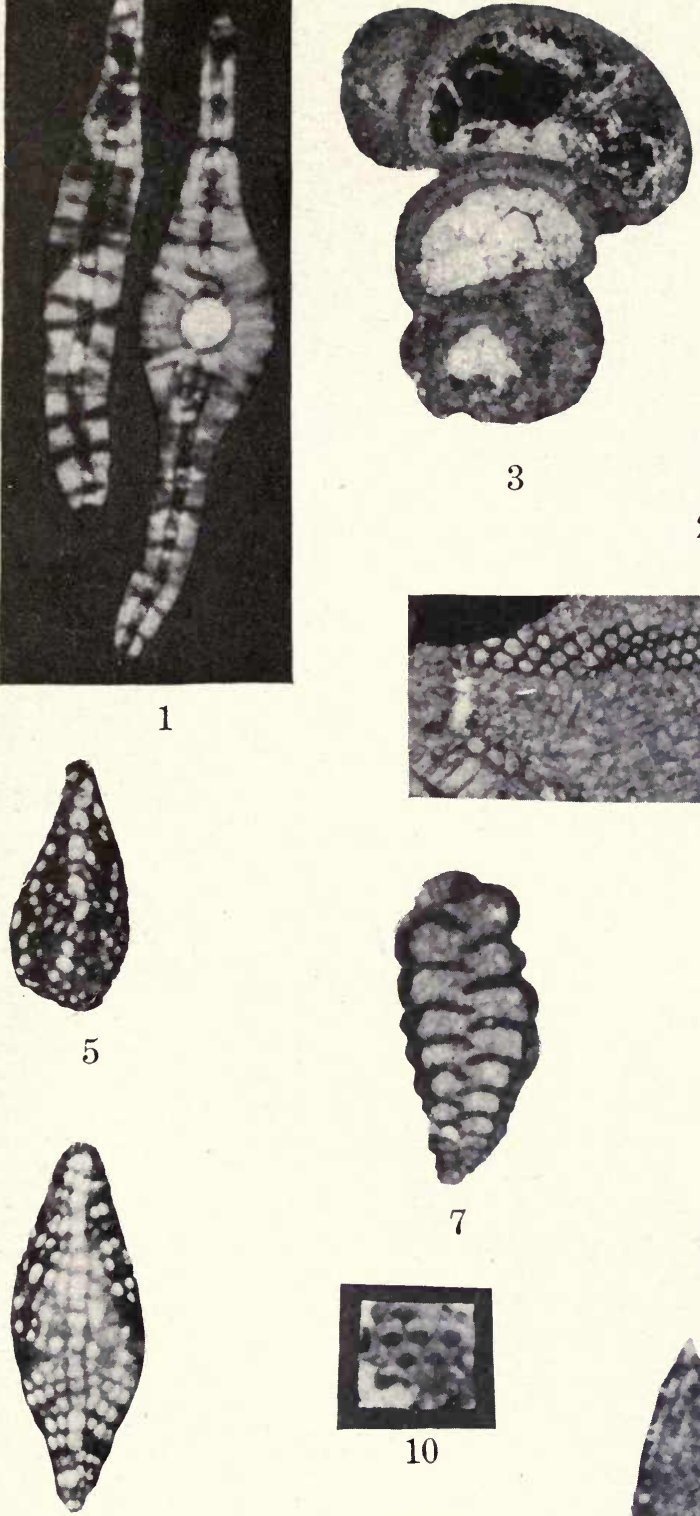

3

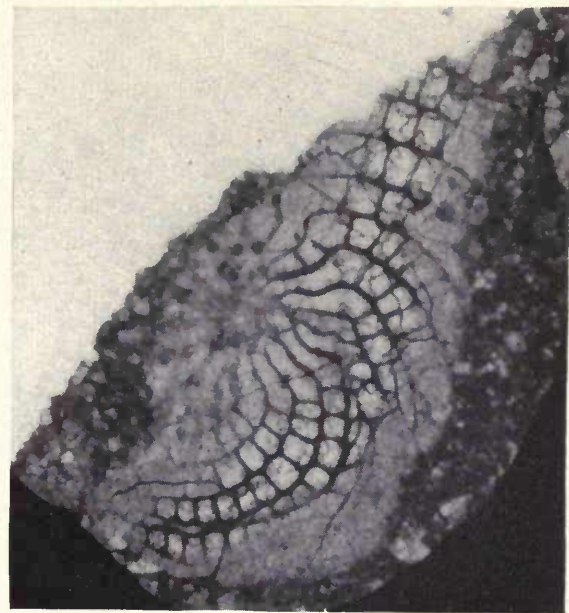

2

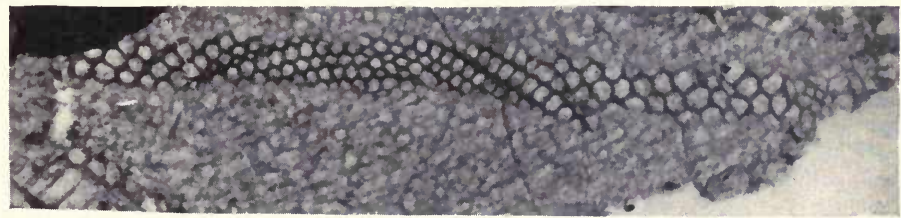

4
5

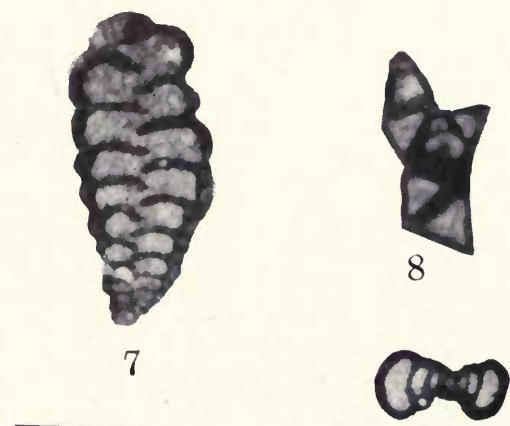

12

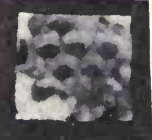

10

6

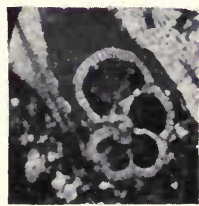

13

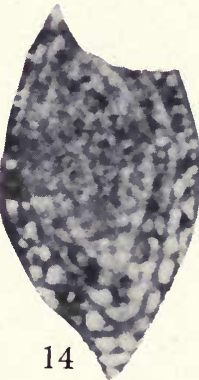

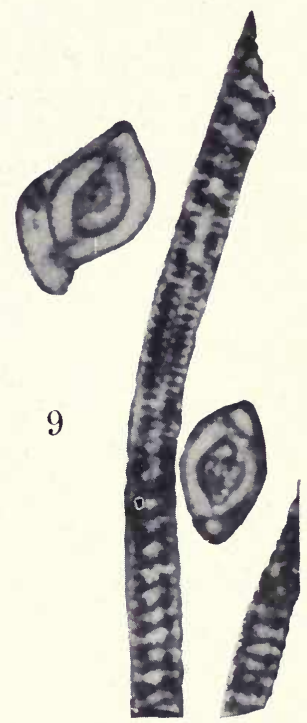

1. Heterostegina antillea, n. sp., vertical sections, one through the proloculum. $\times 20$.

2. Oblique section of $H$. antillea, n. sp., showing some of the chamberlets. $\times 20$.

3. Carpenteria proteus, n. sp., section through several chambers. $\times 20$.

4. Lepidocyclina gigas, n. sp., section through a portion of the hexagonal chambers. $\times 20$.

5 and 6. Heterosteginoides antillea, n. sp. $\times 20$.

7. Textularia sp. Longitudinal section. $\times 20$.

8. Quinqueloculina sp. Incomplete transverse sec-

9. Spiroloculina sp. Section of two specimens, also vertical sections of Orbitolites (Sorites) duplex Carpenter. $\times 20$.

10. Horizontal section through a few chambers of Orbitolites duplex Carpenter. $\times 20$.

11. Nonionina sp. Section, $\times 20$, from Station 6884, Anguilla.

12. Spiroloculina sp. Transverse section. $\times 20$.

13. Globigerina sp. Section. $\times 20$

14. Alveolina sp. Section. $\times 20$. tion. $\times 20$. 


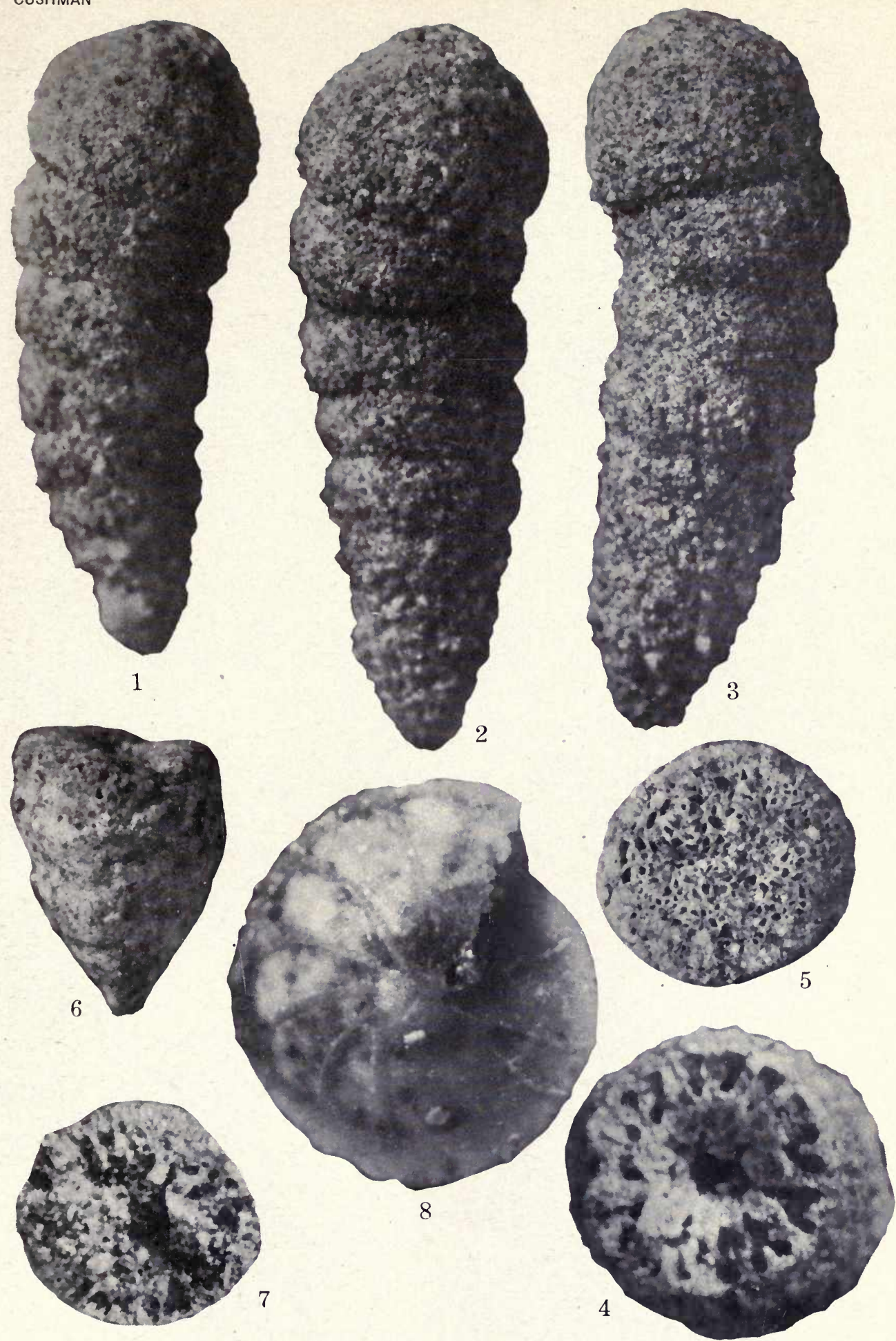

1, 2, and 3. Haplostiche dubia var. intermedia, n. var. $\times 15$.

4. Haplostiche dubia var. intermedia, n. var., horizontal section, showing divisions of the interior. $\times 20$.

5. Textularia barrettii Jones and Parker, end view. $\times 20$

6. Textularia barrettii Jones and Parker, front view. $\times 20$.

7. Textularia barrettii Jones and Parker, horizontal section, showing irregular labyrinthic interior.

8. Cristellaria calcar var. aspinosa, n. var. $\times 20$. All specimens from the Bowden marl. 



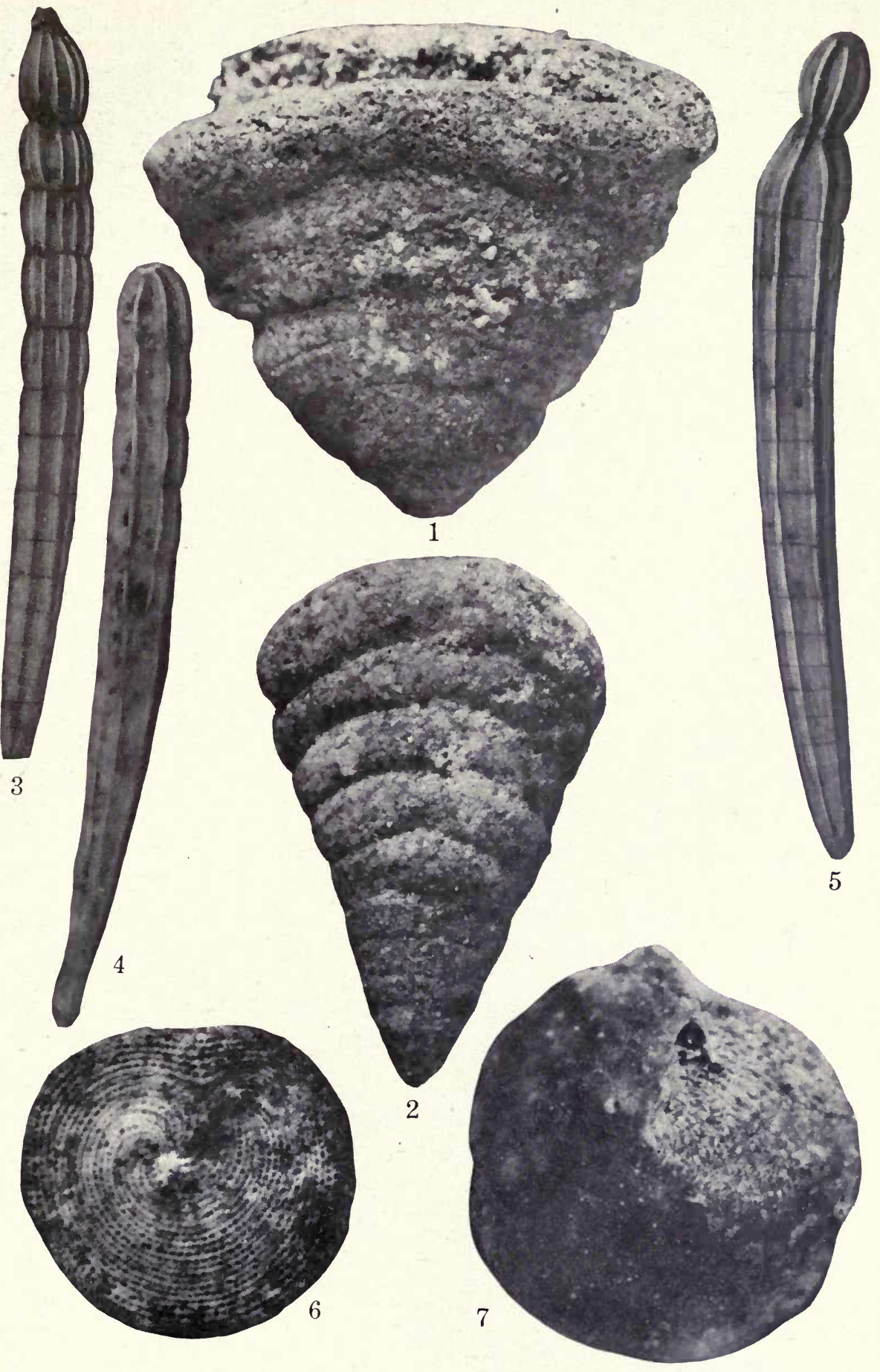

1. Cuneolina pavonia d'Orbigny. $\times 12$.

6. Orbiculina compressa d'Orbigny. $\times 12$.

2. Cuneolina pavoniva var, angusta, n. var. $\times 12$.

3,4 , and 5. Nodosaria vertebralis Batsch. $\times 12$.

7. Amphistegina lessonii d'Orbigny. $\times 12$. All specimens from the Bowden marl. 



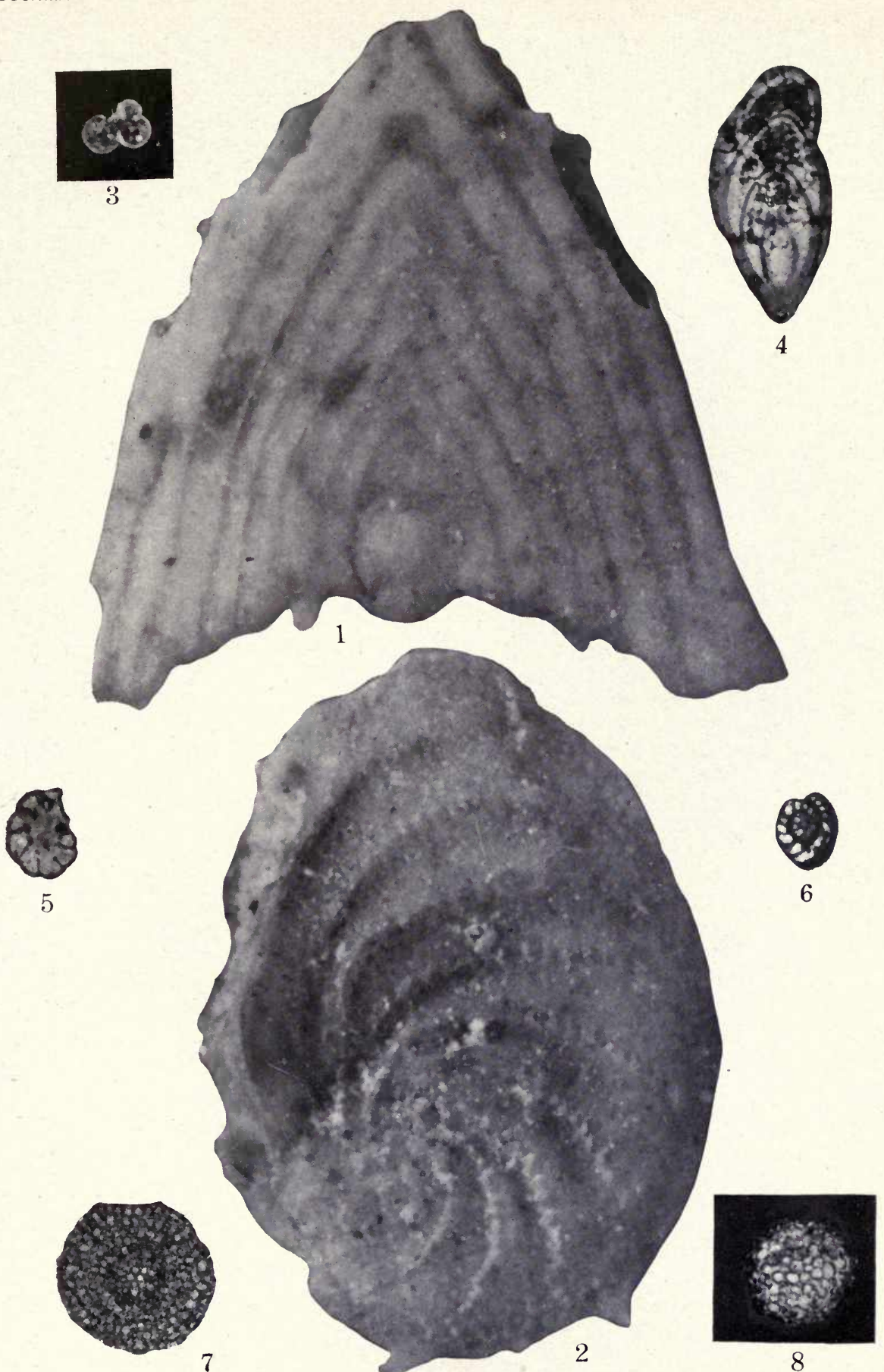

1. Frondicularia alata d'Orbigny. $\times 13$. From 5. Nonionina sp.? $\times 18$. Cuba, Station 6117 . Bowden marl.

2. Cristellaria bowdenensis, n. sp. $\times 13$. From Bowden marl.

6. Rotaliform species. $\times 18$. Cuba, Station 7513.

7. Linderina sp. $\times 18$. Cuba, Station 3448 .

3. Globigerina sp.? $\times 18$. Cuba, Station 7664. 8. Linderina sp.? $\times 18$. Cuba, Station 7666.

4. Polymorphina sp.? $\times 18$. Cuba, Station 7664 . 



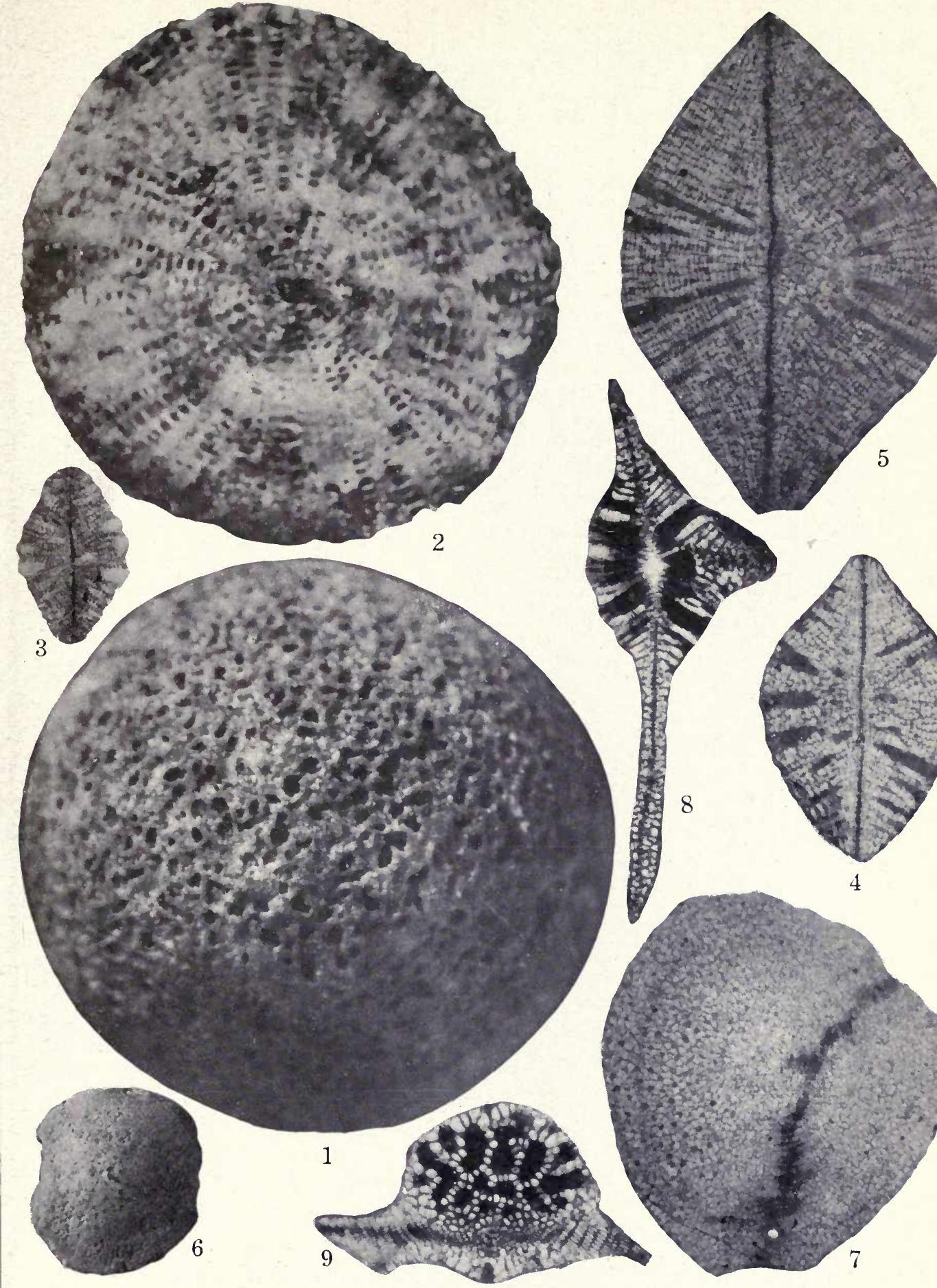

1. Gypsina globulus var. pilaris H. B. Brady. Exterior $\times 15$. From Bowden marl.

2. Gypsina globulus var. pilaris H. B. Brady. $\times 15$. Section from Bowden marl.

3. Orthophragmina cubensis, n. sp. Vertical section. $\times 20 . \quad$ Cuba, Station 3448.

4 and 5. Orthophragmina crassa, n. sp. Vertical sections. $\times 20$. Cuba, Station 6122.

6. Orthophragmina pustulata, n. sp. Exterior. $\times 20$. Cuba, Station 3478 .

7. Orthophragmina pustulata, n. sp. Slightly oblique section, showing equatorial chambers, pillars, and lateral chambers, $\times 20$. Cuba, Station 3667 .

8. Orthophragmina sculpturata, n. sp. Vertical section. $\times 20$. Cuba, Station 3478 .

9. Orthophragmina sculpturata, n. sp. Oblique section, showing rectangular, elongate, equatorial chambers, large pillars with a single series of lateral chambers, between. $\quad \times 20$. 


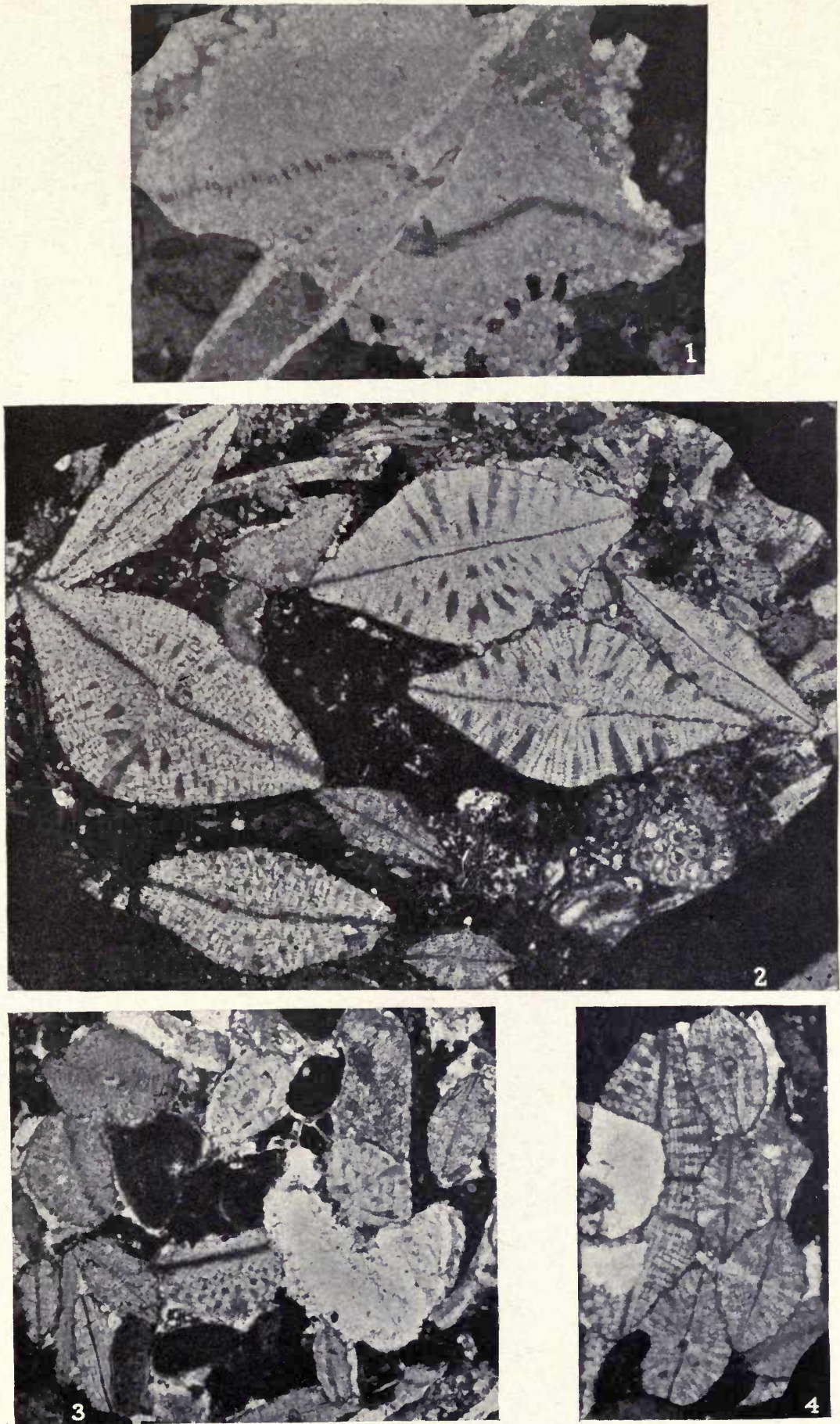

1. Orthophragmina pustulata, n. sp. Oblique section. $\quad \times 16 . \quad$ Cuba, Station 3448 .

2. Section of rock from Cuba, Station 6125 , showing vertical sections of Orthophragmina crassa, n. sp. (large), O. cubensis (small at bottom), and $O$. subtaramellei, at right. $\times 16$.

3. Section of rock from Cuba, sections of Orthophragmina cubensis. $\quad \times 16$.

4. Section of rock from Cuba, Station 3476, showing several sections of Orthophragmina cubensis, n. sp. on right and one of $O$. crassa, n. sp. on left. 



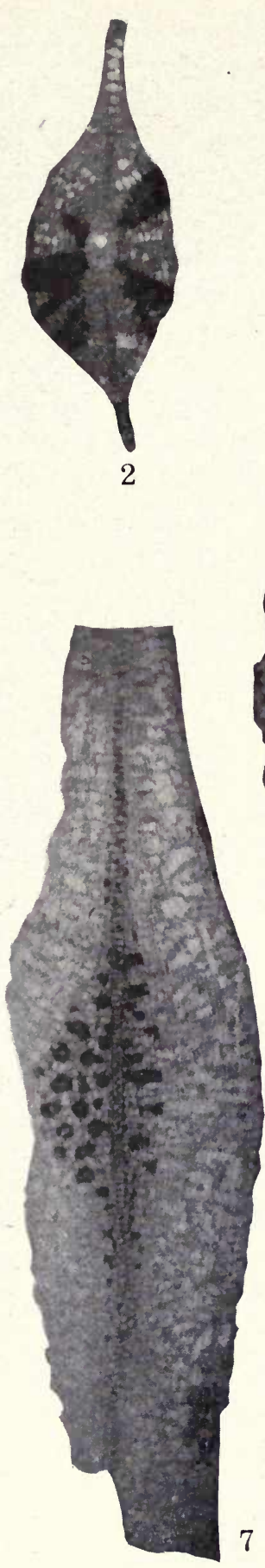

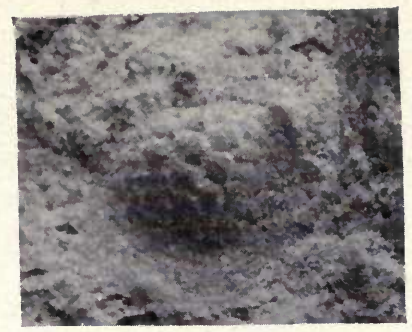

1

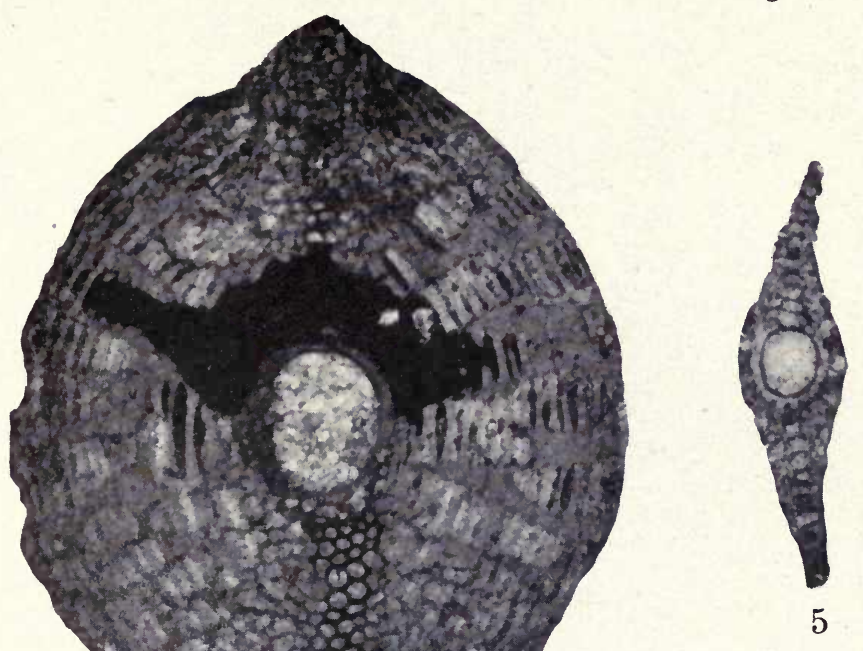

7

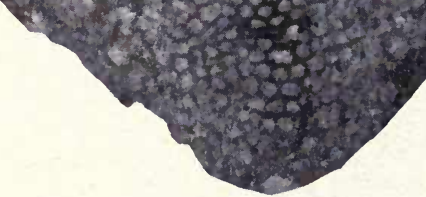

4
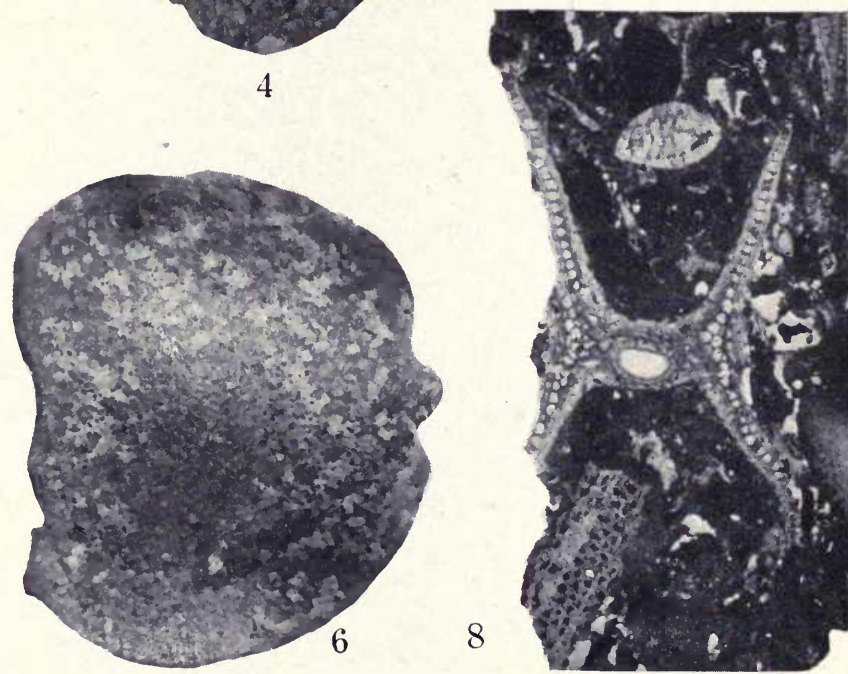

1. Lepidocyclina morgani Lemoine and R. Douvillé. Exterior. $\times 6$. Cuba, Station 7664 .

2. Lepidocyclina morgani Lenoire and $\mathbf{R}$. Douvillé. Vertical section. $\times 16$. Cuba, Station 7664 .

3. Lepidocyclina morgani Lenoire and R. Douvillé. Vertical section. $\times 16$. Cuba, Station 7543 .

4. Lepidocyclina crassata, n. sp. Vertical section, $\times 16$. Cuba, Station 7513 .

5. Lepidocyclina crassata, n. sp. Vertical section, young. $\times 16$. Cuba, Station 7521 .

6. Lepidocyclina subraulinii, n. sp. Exterior. $\times 4$. Cuba, Station 3478.

7. Lepidocyclina subraulinii, n. sp. Vertical section. $\quad \times 8$. Cuba, Station 3478

8. Lepidocyclina perundosa, n. sp. section. $\times 8$. Cuba, Station 3478. 


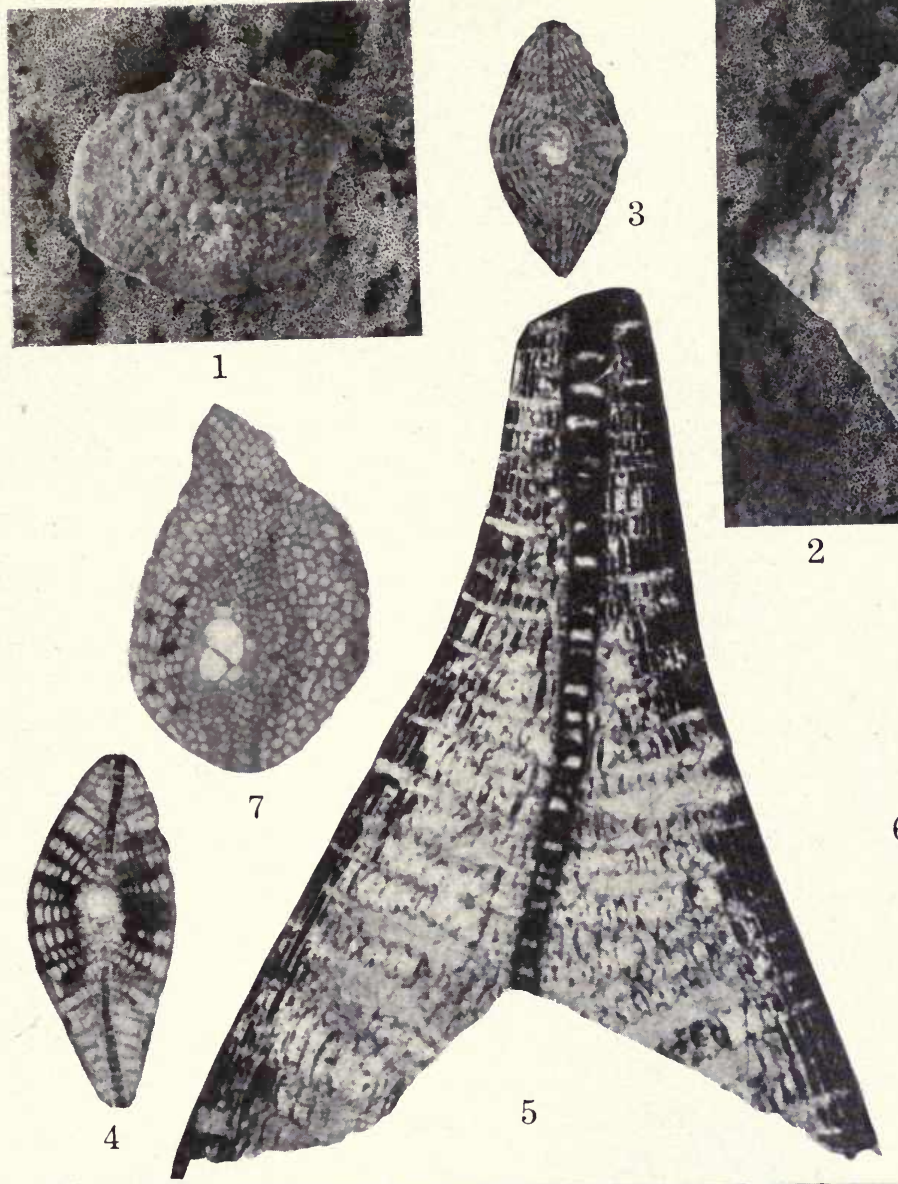

6
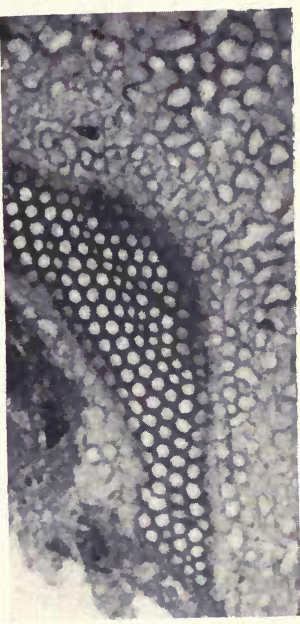

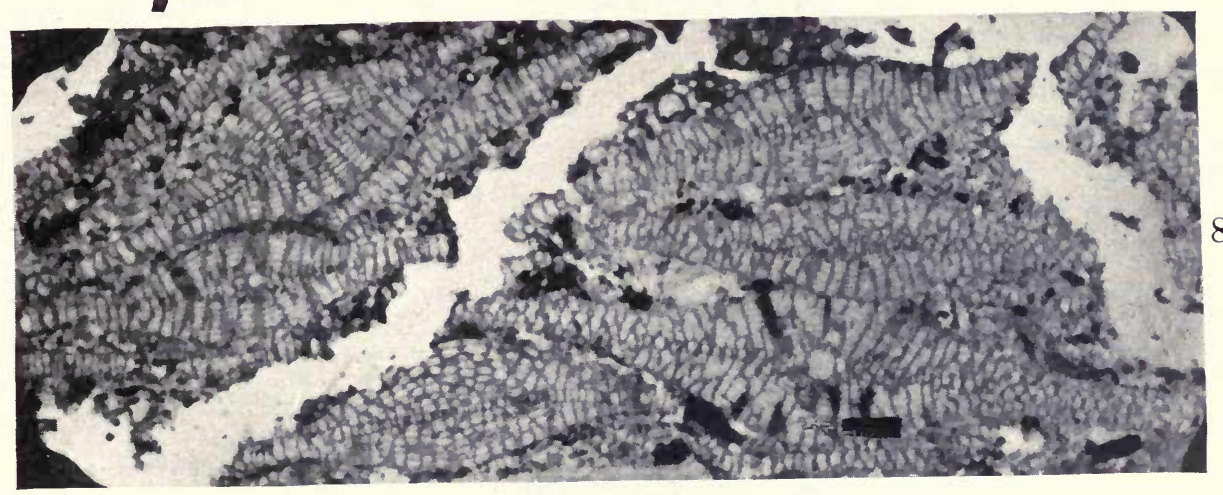

1 and 2. Lepidocyclina marginata (Michellotti). Exterior. $\times 4$. Cuba, Station 7518 .

3 and 4. Lepidocyclina sumatrensis (Brady). Vertical sections." $\times 16$. Cuba, Station 7516 .

5. Lepidocyclina subraulinii, n. sp. Portion of vertical section. $\quad \times 16$. Cuba, Station 7666 .

6. Lepidocyclina subraulinii, n. sp. Portion of oblique section, showing some of the equatorial and lateral chambers. $\times 16$. Cuba, Station 7666 .

7. Lepidocyclina canvellei var. yurnagunensis, n. var. Portion of horizontal section, showing several embryonic chambers, a portion of equatorial chambers, and at the side the lateral chambers. $\times 16$. Cuba, Station 7548 .

8. Rock section showing numerous nearly vertical sections of Lepidocyclina canellei var. yurnagunensis, n. var. $\times 1$. Cuba, Station 7548 . 



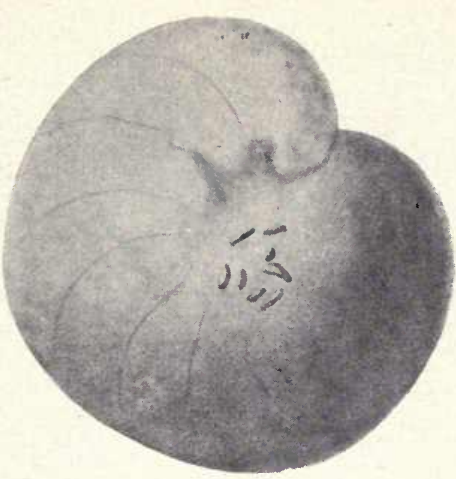

$1 a$
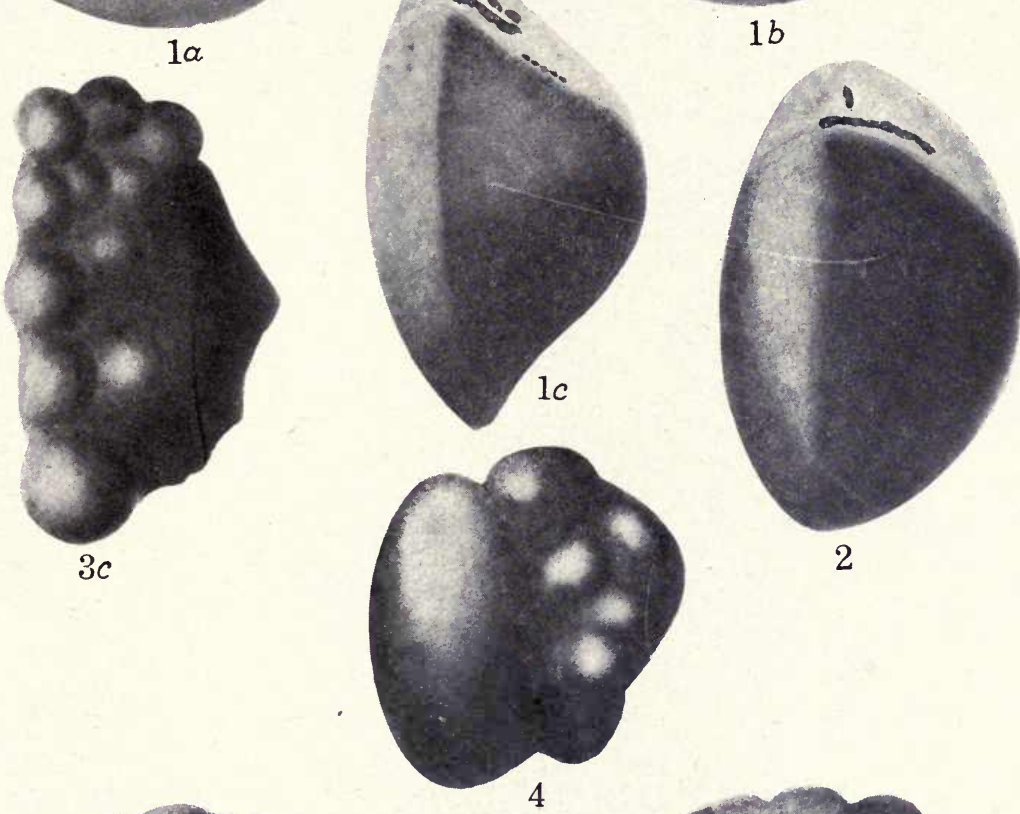

2

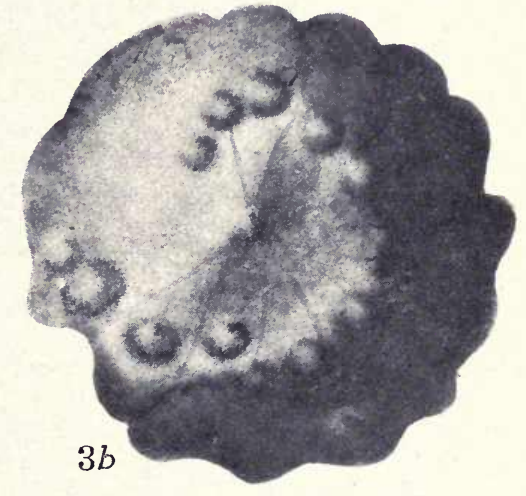

1. Asterigerina angulata, n. sp. (a) Dorsal view; (b) ventral view. $\times 24$. Rio Cana, Zone I . 2. Asterigerina rodundata, n. sp. Apertural view. $\times 24$. Rio Gurabo, Zone G.

3. Asterigerina tuberculata, n. sp. (a) Dorsal view; (b) ventral view; (c) side view. $\times 24$. Rio Cana, Zone I.

4. Asterigerina tuberculata, n. sp. Side view of a more truncate specimen from the same section. $\times 24$.

All specimens from Santo Domingo. 


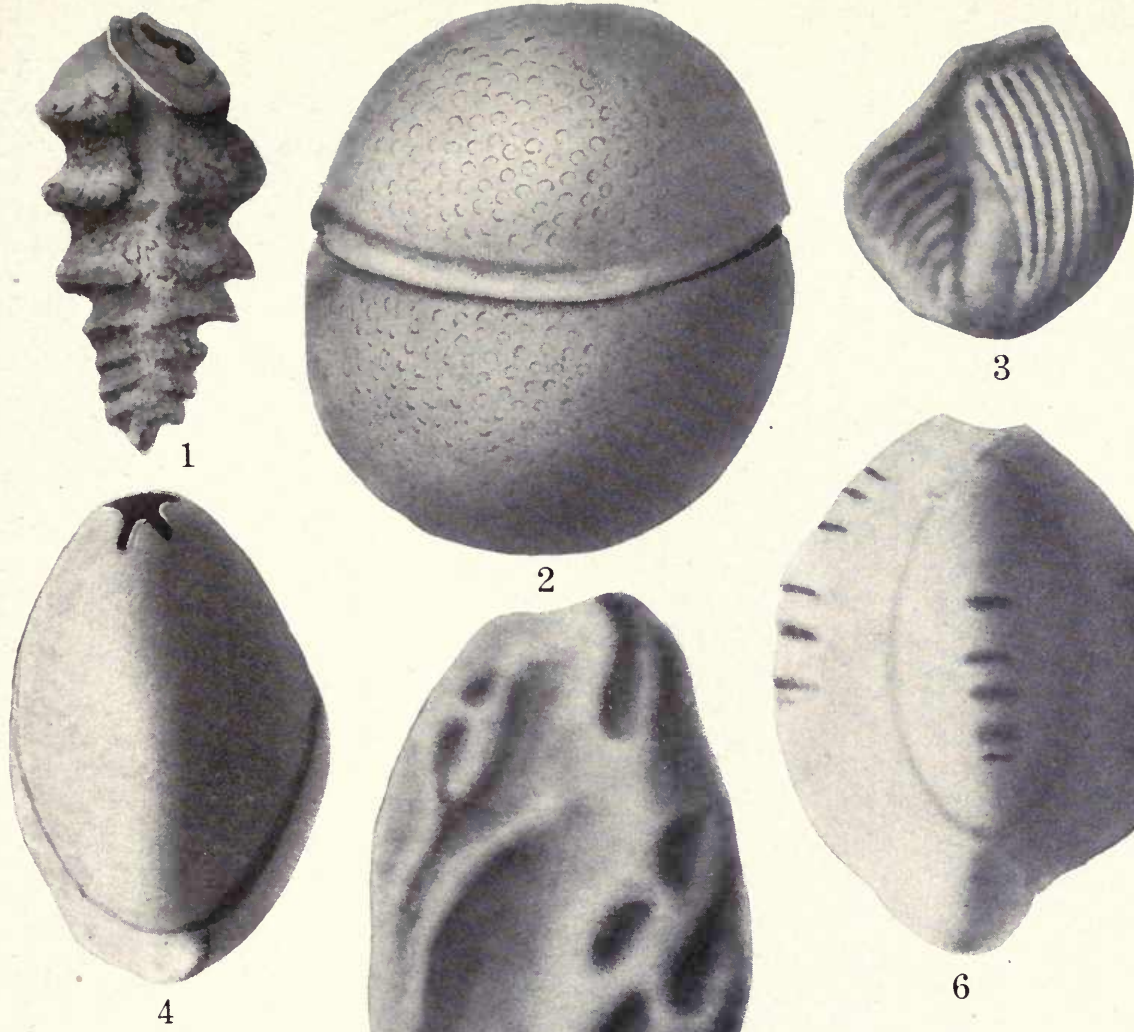

3

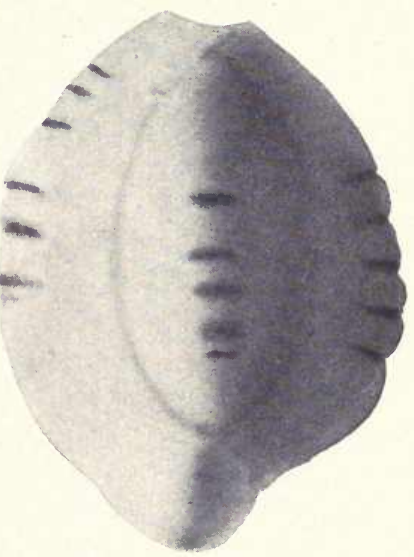

6
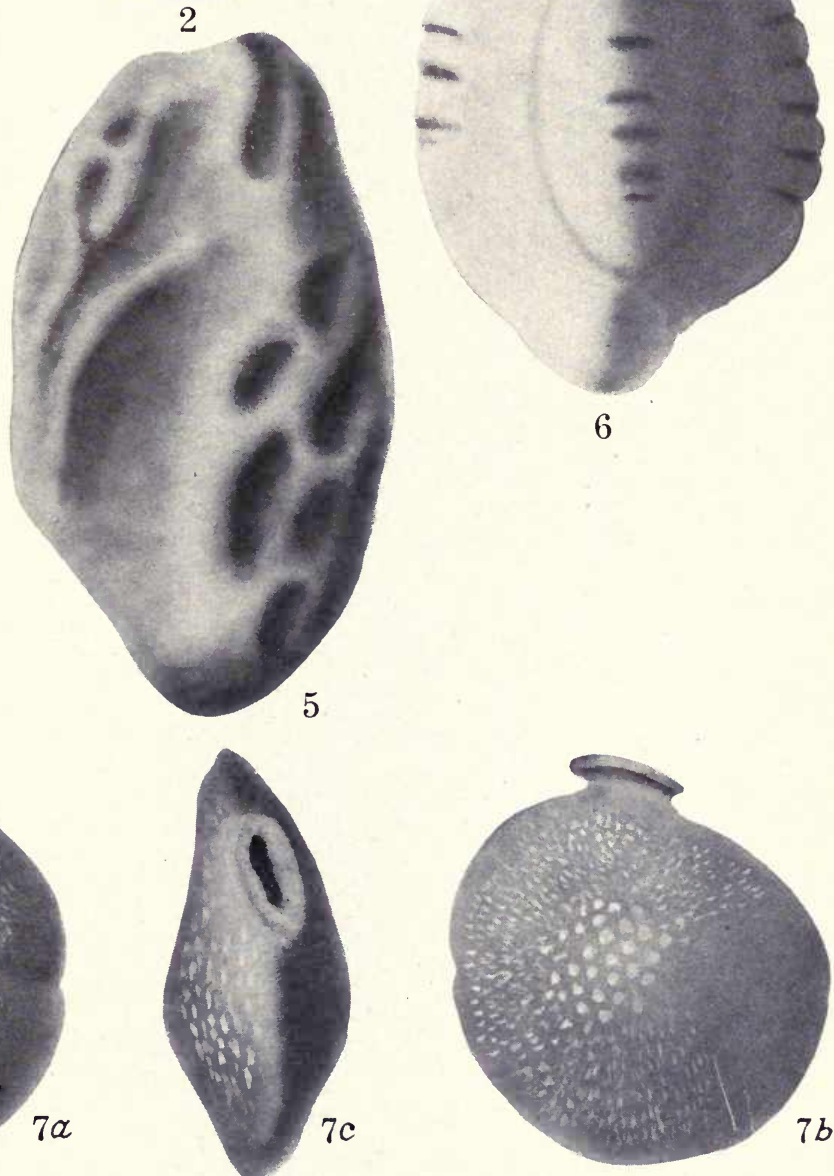

1. Bolivina lobata var. cubensis, n. var. $\times 80$. Matanzas, Cuba, Station 3461 .

2. Sphoroidina dehiscens var. immatura, n. var. $\times 40$. Bowden marl, Bowden, Jamaica.

3. Vertebralina striata d'Orbigny. $\times 40$. Bowden, Jamaica.

4. Triloculina tricarinata d'Orbigny. $\times 40$. Bowden, Jamaica.

5. Quinqueloculina sp. cf. Q. kerimbatica Heron-Allen and Earland. $\times 24$. Bowden, Jamaica.

6. Quinqueloculina parkeri var. bowdenensis, n. var. $\times 40$. Bowden, Jamaica.

7. Siphonina pulchra, n. sp. (a) Dorsal view; $(b)$ ventral view; $(c)$ apertural view. $\times 40$. Matanzas, Cuba, Station 3461. 



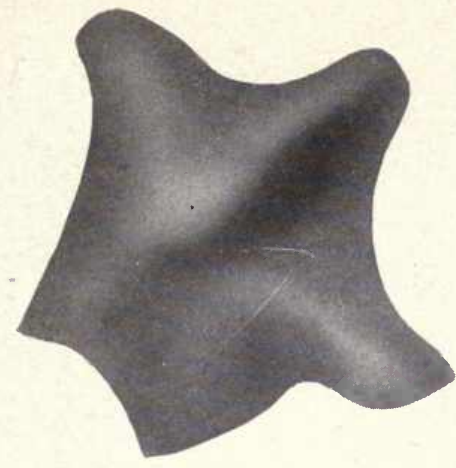

1

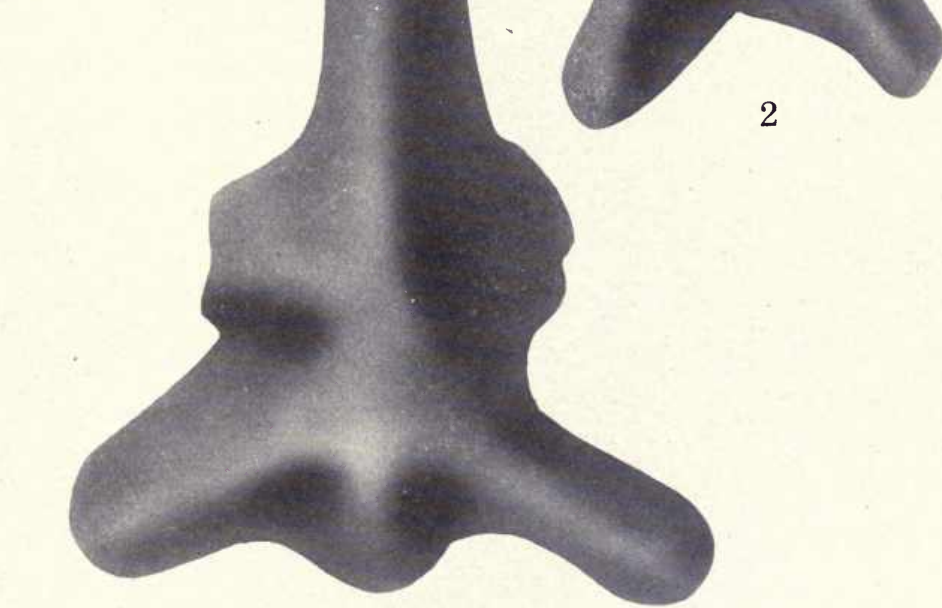

3
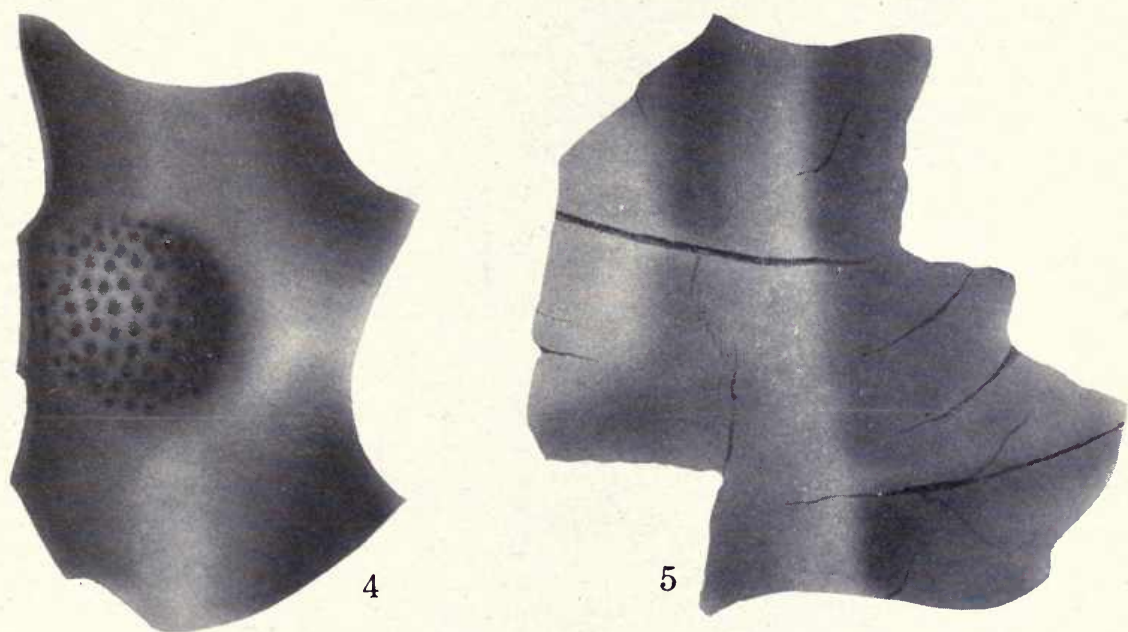

1, 2, and 3. Orthophragmina subtaramellei, n. sp. 1, 2, more regular pentagonal specimens; 3 , irregularly hexagonal specimen. $\times 32$. Specimens from Boston manganese mine, Santiago, Cuba.

4. Lepidocyclina favosa, n. sp., showing central pitted and thickened portion and the doubly curved test. $\times 6$.

5. Lepidocyclina undulata, n. sp. Fragmentary specimen, showing large size and undulate character of surface, 0.8 natural size. 



\section{III.}

\section{FOSSIL BRYOZOA FROM THE WEST INDIES.}

By Ferdinand Canu and Ray S. Bassler.

With seven plates. 


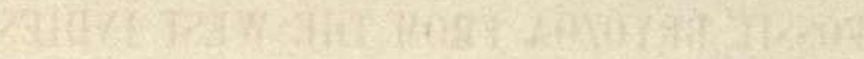

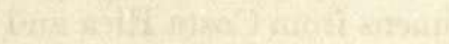
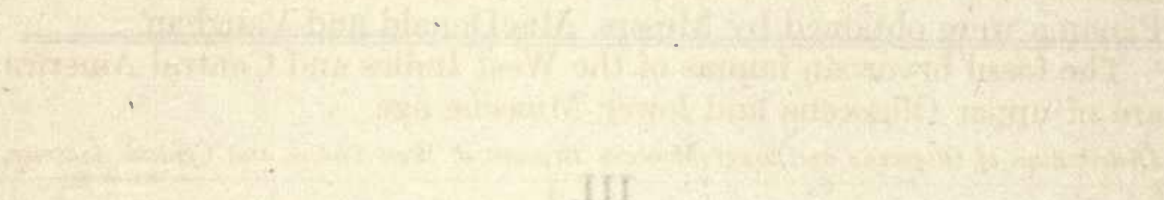

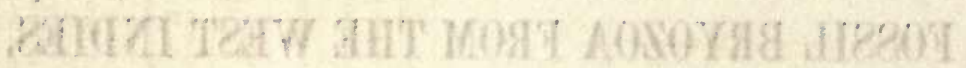

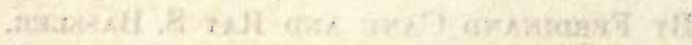

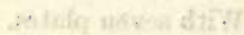




\section{FOSSIL BRYOZ0A FROM THE WEST INDIES.}

By Ferdinand Cand and Ray S. Bassler.

The paper here presented contains descriptions and illustrations of West Indian Tertiary Bryozoa submitted to us by Dr. T. W. Vaughan. The collection from Antigua and Anguilla was made by Doctor Vaughan; that from Bowden, Jamaica, was made by Messrs. J. B. Henderson and C. T. Simpson; and that from Santo Domingo was made by Dr. Carlotta J. Maury. The specimens from Costa Rica and Panama were obtained by Messrs. MacDonald and Vaughan.

The fossil bryozoan faunas of the West Indies and Central America are of upper Oligocene and lower Miocene age.

Distribution of Oligocene and lower Miocene Bryozoa of West Indies and Central America.

\begin{tabular}{|c|c|c|c|c|c|c|c|c|c|}
\hline \multirow[b]{2}{*}{ Species of Bryozoa. } & \multicolumn{3}{|c|}{ Oligocene. } & \multicolumn{4}{|c|}{ Lower Miocene. } & \multirow[b]{2}{*}{ 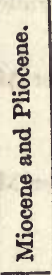 } & \multirow[b]{2}{*}{ 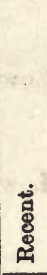 } \\
\hline & 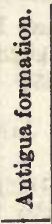 & 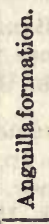 & 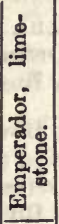 & 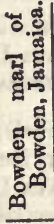 & 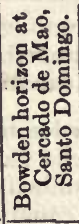 & 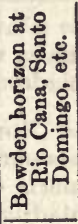 & 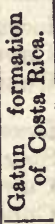 & & \\
\hline Conopeum ovale, $\mathrm{n}$. & & & & $x$ & & & & & \\
\hline pora vaugl & 0 & 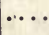 & (a) & & & & $\cdots$ & $x$ & \\
\hline Acanthodesia savarti forma texturata Reuss, i847.. & & & & $\stackrel{x}{x}$ & & & & $\underset{x}{x}$ & \\
\hline odesia savarti forma monilifera, new form... & & & $\because$ & & & & $\cdots \cdots$ & & \\
\hline $\begin{array}{l}\text { Callopora dumerilii var. Jata, n. var } \ldots \ldots \ldots \ldots \ldots \\
\text { Callopora tenella Hincks, } 1880, \ldots \ldots \ldots\end{array}$ & $\cdots$ & $x$ & $\cdots$ & $\because \ddot{x}$ & & & $\cdots$ & & \\
\hline Ogivalina mutabilis, n. 8 p..... & $\because$ & $x$ & $\ddot{x}$ & $x$ & & & & & \\
\hline Nellia oculata Busk, 18 & & & & $\cdots$ & & & $\cdots$ & $x$ & \\
\hline $\begin{array}{l}\text { Floridina pyripora, n. sp.. } \\
\text { Floridina fusifera, n. sp... }\end{array}$ & $\underset{x}{x}$ & $x$ & $\because$ & $\cdots$ & & & $\cdots$ & & \\
\hline & & $\because$ & $\because$. & & & $x$ & $\cdots$ & & \\
\hline Calpensia impressa Moll, 1803 . & $\ddot{x}$ & $\cdots$ & & & & & $\cdots$ & $x$ & \\
\hline $\begin{array}{l}\text { Hemiseptella grandicella, n. } \\
\text { Hemiseptella lata, n. sp.... }\end{array}$ & $\ldots$ & .. & . & $x$ & & & .. & & \\
\hline Cupuladria umbellata Defrance, $1823 . .$. . & $\because$ & .. & & $\ddot{x}$ & & & $\because$ & $\ddot{x}$ & $\ddot{r}$ \\
\hline $\begin{array}{l}\text { stylus labiatus, } \mathrm{n} \text {. } \\
\text { stylus ellipticus, } \mathrm{n} \text {. }\end{array}$ & $\because$ & . & & & & & & & \\
\hline Thalamoporella granulata Levinsen, $1909 .$. & & & & & & & $\because$ & & $\ddot{x}$ \\
\hline Thalamoporella biperforata, n. sp......... & $\cdots$ & . & .. & $\underset{x}{x}$ & & $x$ & . & & \\
\hline $\begin{array}{l}\text { Steganoporella parvicella, n. sp...... } \\
\text { Labiopora miocenica, n. sp........ }\end{array}$ & & & & $x$ & & & & & \\
\hline Puellina radiata carolinensis Gabb and Horn, $1862 . \ldots \ldots$ & $\ddot{x}$ & $\ddot{x}$ & & & & & & & \\
\hline 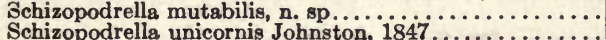 & $\cdots$ & $\ldots$ & & $\ddot{x}$ & & & & $x$ & \\
\hline Stylopoma spongites Pallas, $1766 \ldots$ & $\cdots$ & $\ddot{x}$ & $\because$ & $\ddot{x}$ & & & - & $x$ & \\
\hline Stephanosella biaperta Michelin, $1842 \ldots \ldots \ldots \ldots$ & $\cdots$ & $\mathrm{x}$ & & $x$ & & & $\cdots$ & $x$ & $x$ \\
\hline $\begin{array}{l}\text { Gemelliporella punctata, n. sp........ } \\
\text { Hippomenella infratelum, n. sp..... }\end{array}$ & & $\cdots$ & $\because$ & $x$ & $x$ & & & & \\
\hline $\mathrm{Hi}$ & $\ddot{x}$ & & & & & & & & \\
\hline Porella bella Busk, $1860 \ldots$ & $x$ & .. & .. & & & & & & \\
\hline brevis, $n$. sp. & $\cdots$ & $\because \cdots$ & 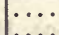 & $x$ & $x$ & & 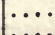 & & . \\
\hline oon vaughani & & $\because$ & & & & & & & \\
\hline dotos collig: & & & & & $x$ & $\ddot{x}$ & & & \\
\hline abdotos lacrymosum, n. sp... & & & & $x$ & & & & & \\
\hline porosa, n. sp... ïं & & & & $x$ & & & & $x$ & $\ddot{x}$ \\
\hline dgia defor & - & $\cdots$ & $\cdots$ & $\hat{x}$ & & & .. & & \\
\hline Holoporella albirostris Smitt, 1873 .. & ... & $x$ & $x$ & $x$ & & & $x$ & $x$ & $x$ \\
\hline $\begin{array}{l}\text { Stichoporina tuberosa, n. } \\
\text { Idmonea milneana d'Or }\end{array}$ & & & $\cdots$ & $x$ & $\stackrel{x}{x}$ & & & & \\
\hline
\end{tabular}




\section{Locality and faunal list.}

Oligocene (Emperador limestone) old quarry; one-third mile north of west of Empire, Panama Canal Zone (loc. No. 6016):

Ogivalina mutabilis, n. sp. Holoporella albirostris Smitt, 1873.

Oligocene (Antigua formation), Carlisle marl pit, Antigua, Leeward Islands (loc. No. 6873):

Calpensia impressa Moll, 1803.

Oligocene (Antigua formation), Rifle Butts, Antigua, Leeward Islands (loc. No. 6854):

Floridina pyripora, n. sp.

Floridina fusifera, n. sp.

Puellina radiata carolinensis Gabb and

Horn, 1862.

Oligocene (Anguilla formation), southwest side of Crocus Bay bluffs, uppermost horizon, 125 feet above sea-level, Anguilla, Leeward Islands (loc. No. 6967):

Callopora dumerilli var. lata, n. var. Puellina radiata carolinensis Gabb and Floridina pyripora, n. sp. Horn, 1862

Oligocene (Anguilla formation), southwest side of Crocus Bay, Anguilla, Leeward Islands (loc. No. 6894):

Holoporella albirostris Smitt, 1873. Stylopoma spongites Pallas, 1766.

Oligocene (Anguilla formation), along roadside, Crocus Bay Hill, descent to Crocus Bay from valley, Anguilla, Leeward Islands (loc. No. 6893):

Stephanosella biaperta Michelin, 1842. Ogivalina mutabilis, n. sp.

Lower Miocene (Gatun formation), Banana River, Costa Rica:

Cupularia umbellata Defrance, $1823 . \quad$ Stichoporina tuberosa, n. sp.

Cupuladria canariensis Busk, 1859

Lower Miocene (Bowden marl), Bowden, Jamaica:

Steganoporella parvicella, n. sp.

Cupularia umbellata Defrance, 1823.

Cupuladria canariensis Busk, 1859.

Conopeum ovale, n. sp

Acanthodesia savarti forma texturata Reuss, 1847.

Callopora tenella Hincks, 1880.

Hemiseptella grandicella, n. sp.

Thalamoporella biperforata, n. sp.

Stylopoma spongites Pallas, 1766.

Schizopodrella unicornis Johnston, 1847.

Gemelliporella punctata, n. sp.

Rhamphostomella laticella, $n$. sp.

Metrarabdotos lacrymosum, n, sp.

Adeona heckeli Reuss, 1847.

Bracebridgia deformis, n. sp.

Holoporella albirostris Smitt, 1873.

Stichoporina tuberosa, n. sp.

Lower Miocene (Bowden horizon), Cercado de Mao (bluff 3), Santo Domingo:

Membranipora vaughani, n. sp.

Acanthodesia savarti forma monilifera, new form.

Nellia oculata Busk, 1852.

Cupuladria umbellata Defrance, 1823.

Cupuladria canariensis Busk, 1859

Steganoporella parvicella, n. sp.

Hippomenella infratelum, n. 8p.

Schizopodrella (?) mutabilis, n. sp.

Smittina (?) brevis, n. sp.

Rhynchozoon vaughani $\mathrm{n}$. sp.

Metrarabdotos colligatum, n. sp.

Adeona porosa, n. sp.

Idmonea milneana D'Orbigny, 1839.

Lower Miocene (Bowden horizon), Cercado de Mao (bluff 2), Santo Domingo:

Cupularia umbellata Defrance, 1823.

Lower Miocene (Bowden horizon), Rio Gurabo (zone D), Santo Domingo:

Lunularia species.

Cupularia umbellata Defrance, 1823.

Cupuladria canariensis Busk, 1859.

Thalamoporella granulata Levinsen, 1909.

Thalamoporella biperforata, n. sp.

Labiopora miocenica, $\mathrm{n}$. sp.

Stichoporina tuberosa, n. sp.

Lower Miocene (Bowden horizon), Rio Cana (zone I), Santo Domingo:

Stichoporina tuberosa, n. 8 p.

Cupuladria canariensis Busk, 1859.

Thalamoporella biperforata, n. sp.

Lower Miocene (Bowden horizon), Rio Cana (zone H), Santo Domingo:

Metrarabdotos colligatum, n. sp. 
Class BRYOZOA.

Order CHEILOSTOMATA Busk.

Suborder ANASCA Levinsen.

Group MEMBRANIPORE Canu and Bassler.

Genus CONOPEUM Norman, 1903.

Conopeum ovale, new species.

(Plate 5, Figure 6.)

The zoarium incrusts shells. The zoœcia are oval, elongate, distinct, separated by a deep furrow; the mural rim is wide, flat, almost smooth; the opesium is elliptical or oval.

Measurements. ${ }^{1}$ Opesium: $h o=0.30 \mathrm{~mm}$., $l o=0.15 \mathrm{~mm}$.; zoœcium: $L z=0.35$ $\mathrm{mm}$., $l z=0.25 \mathrm{~mm}$.

Affinities.-The figured specimen is the only one that has been found and as it is incomplete it is impossible for us to present a detailed study of the species. The ancestrular zoccia are calcified. A small avicularium appears to be present between the mural rims of some zoœcia.

Occurrence.-Lower Miocene (Bowden marl), Bowden, Jamaica (very rare).

\section{Genus MEMBRANIPORA Blainville, 1834 .}

Membranipora vaughani, new species.

(Plate 2, Figure 1.)

Cfr. Membranipora tuberculata Busk, Fossil Polyzoa of the Crag, Paleontographical Society, p. 30, plate II, fig. 1,1859 .

Measurements.-Opesium: $h o=0.32$ to $0.36 \mathrm{~mm}$., $l o=0.22$ to $0.24 \mathrm{~mm}$; zoœcium: $L z=0.40$ to $0.44 \mathrm{~mm}$., $l z=0.32 \mathrm{~mm}$.

The figured specimen is the only one found. It incrusts a small, very convex molluse which has deformed the zoocia by its shape. This is not the species of Busk, 1858, nor that of Bosc, 1830, which it resembles only in the presence of large interopesial tubercles, but we can not fully define a new species upon such a minute fragment.

The figured specimen is really too large in its micrometric measurements to be compared with the species figured by Busk, 1859 .

Lower Miocene (Bowden horizon), Cercado de Mao (Bluff 3), Santo Domingo.

\section{CUPULADRIA, new genus.}

Etymology.-Modification of Cupularia.

No ovicell. The zoarium bears vibracula. No gymnocyst.

Genotype.-Cupuladria (Cupularia) canariensis Busk, 1859.

Range.-Miocene-Recent.

The genotype does not belong at all to the genus Cupularia as we now, understand this genus and as it is defined by its type species. There are neither opesiules nor cryptocyst. Previously, Smitt, in 1872,

${ }^{1}$ In the citation of measurements, $h o$ is the length and $l o$ the width of the opesia, $L z$ and $l z$ similarly the length and width of the zoccia, $L v$ and $l v$ the same for the vibraculum, Lon and lon for the onychocellaria, $h a$ and $l a$ for the apertura, etc. 
classified the genotype more correctly in Membranipora, as this genus was then understood. It can not, however, be maintained in $\mathrm{Mem}$ branipora, since its significance has been more restricted. We have therefore been obliged to create a new genus characterized by the presence of vibracula, although these organs of zoarial adaptation may not logically furnish good generic characters. We only add a letter to the primitive term to modify the long synonymy of this species as little as possible.

This genus differs from Heliodoma Calvet, 1907, in the absence of a gymnocyst. The absence of an endozoœcial ovicell does not permit it to be confused with either Vibracellina Canu and Bassler, 1917, or Setosellina Calvet, 1907.

\section{Cupuladria canariensis Busk, 1859 .}

(Plate 1, Figures 8 to 10.)

Cupularia canariensis Busk, Monograph fossil Polyzoa of the Crag, Publications Paleontographical Society, London, XIV, p. 87, plate 13, fig. 2, 1859.

Membranipora canariensis Smitt, Floridan Bryozoa, collected by Count L. F. de Pourtales, Pt. I, Kongl. Svenska Vetenskaps-Akademiens Handlingar, X, No. 11, p. 10, 1872.

Cupularia canariensis Canu, Iconographie des Bryozoaires fossiles de L'Argentina, Première partie. Anales del Museo Nacional de Buenos Aires, tome XVII, p. 275, plate v figs. 8 to 10 (gives bibliography), 1908 .

Cupularia guineensis Norman, The Polyzoa of Madeira and neighboring islands, Journal Linnean Society London, Zoology, XXX, p. 289, plate 37, figs. 2 and 6, 1909.

Cupularia canariensis Canu, Contributions à l'étude des Bryozoaires fossiles, IV, Pliocene d'Alger, Bulletin Societè Géologique France (4), XIII, p. 124, 128, 1914.

Cupularia guiniensis Osburn, The Bryozoa of the Tortugas Islands, Florida, Carnegie Inst. Wash. Pub. No. 182, p. 194, 1914.

Cupularia canariensis Canu, Bryozoaires fossiles des Terraines du Sud-Ouest de la France, IX, Aquitanien, Bulletin de la Société Géologique de France (4), XVI, p. 137, plate III, figs. 4 to 6 .

This species may be considered as equatorial. In spite of its geologic extension, it has never left the tropical zone or its immediate latitudes. Like Membranipora tuberculata Bosc, 1802, it appears to have been carried to America by the equatorial current. It is comparatively rare in our fossils and has never been found north of southern Florida.

Occurrence.-Lower Miocene (Bowden horizon), Bowden, Jamaica (rare); Rio Gurabo, Rio Cana, and Cercado de Mao, Santo Domingo (rare); lower Miocene (Gatun formation), Banana River, Costa Rica (rare); Miocene (Choctawhatchee marl), Jackson Bluff, Ochlockonee River, 25 miles southwest of Tallahassee, Florida (rare); upper Pliocene (Caloosahatchee marl), Monroe County, Florida (rare).

Geological distribution.-Burdigalian of Bordeaux (collection Canu); Helvetian of France (Canu); of Spain (De Angelis); Tortonian of Austria-Hungary (Reuss); of Italy (Seguenza); Plaisancian of Italy (Manzoni); of England (Busk); of Spain (De Angelis); of Algeria (Canu); Astian of Italy (Neviani, Canu); Sicilian of Rhodes (Manzoni); of Italy (Neviani); Quaternary of Italy (Neviani), of Argentina (Canu); Miocene of Australia? (Waters). 
ACANTHODESIA, new genus.

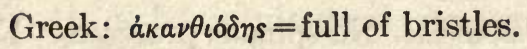

The following is a description of this genus:

No ovicell. The opesium is garnished laterally by small spinous processes and inferiorly by a serrate denticle. 15 tentacles.

Genotype.-Acanthodesia (Flustra) savartii Savigny-Audouin, 1826.

Range.-Lutetian-Recent.

Another species of this new genus is Membranipora limosa Waters, 1908. Waters classified the genotype in the same group as Membranipora hians Hincks, 1885. This is incorrect, since Flustra savartii is deprived of opesiules and its large retractor muscle of the polypide inserted on the median axis of the zoœcium assures the symmetry of the opesium; moreover, there is no ovicell.

The spinous processes are of the same nature as those of the genera Hemiseptella Levinsen, 1909, and Cupularia Defrance, 1821, but they are very inconstant; in fact they have not been noted on the recent specimens, nor are they very frequent on the fossils. On the contrary, the serrate denticle is rarely found in the fossil examples.

\section{Acanthodesia savartii forma monilifera, new form.}

(Plate 2, Figures 2, 3.)

The following is a description of this form:

The zoarium is a tube formed of 8 longitudinal rows of zoœcia, incrusting the radicells of algæ. The zoœcia are distinct, much elongated, adjacent at their mural rims, almost rectangular; the mural rim is round, salient, ornamented with large, regular beads, arranged like a collar around each zoœcium. The opesium is elongate, elliptical or oval, surrounded and crenulated by large tuberosities. There is no cryptocyst developed.

Measurements.-Opesium: $h o=0.34 \mathrm{~mm}$., $l o=0.18 \mathrm{~mm}$.; zoœecium: $L z=0.48$ $\mathrm{mm}$., $l z=0.28 \mathrm{~mm}$.

This form differs from typical Acanthodesia savartii Savigny-Audouin, 1826, which has analogous zoœcia, in the presence of granulations on the mural rim. Often a large tubercle is developed in the interzoœcial angle. But a single specimen of this superb form has been found.

Occurrence.-Lower Miocene (Bowden horizon), Cercado de Mao, (Bluff 3), Santo Domingo.

\section{Acanthodesia savartii forma texturata Reuss, 1847.}

(Plate 5, Figures 1 to 5.)

Flustrellaria texturata Reuss, Die fossilen Polyparien des Wiener-Tertiarbeckens, Haidinger's naturwissenschaftliche Abhandlungen, II, p. 73, plate IX, fig. 1, 1847.

Biflustra savarti Smitt, Floridan Bryozoa, collected by Count L. F. de Pourtales, Part I, Kongl. Svenska Vetenskaps-Akademiens Handlingar, X, No. 11, p. 20, plate IV, figs. 92 to 95,1872 .

Flustrellaria texturata Manzoni, I Briozoi fossili del Miocene d'Austria ed Ungheria, II Parte Denkschriften der math. natur. Classe der k. Akademie der Wissenschaften, XXXVII, 2 Abtheilung, p. 67 , plate 13 , fig. $43,1877$. 
The following is a description of this form:

The cryptocyst is developed on all the zoøcia. No spinous processes. No tubercles. The zoarium is unilamellar and subcylindrical.

Measurements.-Opesia: $h o=0.35 \mathrm{~mm}$., lo $=0.20 \mathrm{~mm}$.; zoœcia: $L z=0.50$ $\mathrm{mm} ., \mathrm{l} z=0.28 \mathrm{~mm}$.

Variations.-The zoarium incrusts fine algæ at their bifurcation; it is therefore unilamellar and subcylindrical.

The zoœcia are elongated, ogival, distinct; the mural rim is striated, salient only in the distal portion; the cryptocyst is large and concave. The opesium is elliptical, very finely denticulated anteriorly; it often bears thin and short spinous processes.

Smitt figured the serrate denticle on the recent specimens; it never persists on the fossil examples. On the inner face the zoccia are rectangular.

Affinities.-The presence of the spinous processes differentiates our specimens from Flustrellaria texturata from the European Tortonian, which, according to the figures, does not bear them.

Occurrence.-Lower Miocene (Bowden horizon), Bowden, Jamaica; Pleistocene or Recent, Vero, Florida.

Geologic distribution.-Tortonian of Austria-Hungary (Manzoni); Recent off Florida (Smitt).

\section{Genus OGIVALINA Canu and Bassler, rgiz. \\ Ogivalina mutabilis, new species.}

(Plate 1, Figure 4.)

The following is a description of this species:

The zoarium is incrusting. The zoœcia are elongated, oval, distinct, separated by a deep furrow; the mural rim is thin, smooth, rounded; there is often a small gymnocyst. The opesium is very large, irregular, more often oval. The ovicell is endozocecial, small, little convex. Sometimes there is a small interzocecial fusiform avicularium (?).

Measurements.-Opesium: $h o=0.60$ to $0.70 \mathrm{~mm}$., $l o=0.30$ to $0.45 \mathrm{~mm}$.; zoœcium: $L z=0.75$ to $0.95 \mathrm{~mm}$., $l z=0.50$ to $0.70 \mathrm{~mm}$.

The great irregularity of form and zoccial dimensions of this species justifies its name. There are some variations which recall those of Membranipora irregularis Manzoni, $1875,{ }^{1}$ which possesses a mural rim enlarged at the base and also some large interzoccial avicularia.

The present species differs from the splendid Ogivalina eximipora (Canu and Bassler, 1917) from the middle Jacksonian in its smaller dimensions, in the absence of cryptocyst, and in the presence of a gymnocyst. The avicularium (?) is identical in form and position.

Occurrence.-Oligocene (Emperador limestone), old quarry, one-third mile north of west of Empire, Panama Canal Zone, D. F. MacDonald and T.W.Vaughan, collectors, 1914, loc. No.6016. Oligocene (Anguilla formation), southwest side Crocus Bay Hill, Anguilla, Leeward Islands, T. W. Vaughan, collector, 1914, loc. No. 6893.

\footnotetext{
${ }^{1}$ Briozoi del pliocene antico di Castrocaro, Bologna, p. 10, plate 1, figs. 5 and 8, 1875.
} 


\section{Genus CALLOPORA Gray, 1848.}

Callopora dumerilii var. lata, new variety.

(Plate 1, Figure 1.)

Membranipora dumerilii Canu, Étude des bryozoaires helvétiens de l'Egypte, Mémoires de l'Institut Egyptien, VI, p. 196, plate X, fig. 7 (see for complete bibliography), 1913. Membranipora dumerilii Levinsen, Mosdyr, Zoologica danica, heft 9, p. 57, plate Iv, figs. $22-25,1894$.

Membranipora guernei Jullien, Résultats des campagnes scientifiques du Prince de Monaco, Fasc. XXIII, Bryozoaires provenant des Campagnes de l'Hirondelle, XXIII, p. 4, plate $\mathrm{v}$, fig. 3, 1903.

Callopora dumerilii Norman, On the Polyzoa of Madeira and neighboring islands, Linnean Society's Journal, Zool., XXX, p. 287, 1909.

This new variety is instituted for the form of this species in which a certain number of the zoœcia have only a single avicularium placed in front of the opesium, as in the genus Ramphonotus. On these specimens, moreover, there is not a single opesium resembling its neighbor, but in general the elongated zoœcia are less common. For this reason we have believed that the American Jacksonian and the Anguilla specimens should be separated as a variety. The differences from the recent type specimens are slight, the larger size of the opesium measuring $0.25 \mathrm{~mm}$. in the species instead of $0.20 \mathrm{~mm}$. in the variety, being too small a difference for the erection of a new species.

American occurrence.-Oligocene (Anguilla formation), southwest side Crocus Bay bluffs, uppermost horizon, 125 feet above sea-level, Anguilla, Leeward Islands, T. W. Vaughan, collector, 1914 (loc. No. 6967); middle Jacksonian, Wilmington, North Carolina.

\section{Callopora tenella Hincks, 188 .}

(Plate 5, Figure 10.)

Membranipora tenella Hincks, Annals and Magazine Natural History. (5), vol. 6, p. 25, plate xvi, fig. 7, 1880.

Membranipora tenella Jelly, A synonymic catalogue of recent marine Bryozoa, p. 167, 1889.

Affinities.-This species is quite easily recognized by its very thin mural rim and especially by its small tubercles arranged more or less symmetrically on the gymnocyst. These tubercles appear to be hollow.

The great geological distribution of this Recent species presupposes a considerable corresponding geographical distribution, which has not yet been observed. Osburn did not discover this species in the present Gulf of Mexico.

The species may perhaps be confused with Callopora dumerilii Savigny-Audouin, 1826, in which the exterior aspect is quite similar; it differs from it in the presence of nodules instead of avicularia placed on the gymnocyst (and not between the opesia).

Occurrence.-Lower Miocene (Bowden marl), Bowden, Jamaica.

Habitat.-Florida (Hincks). 
Family FARCIMINARIID Be Busk, 1852.

Genus NELLIA Busk, 1852 .

Nellia oculata Busk, 1852 .

(Plate 2, Figures 5 to 7. )

Farcimia tenella Lamarck, Histoire naturelle des animaux sans vertèbres, vol. 2, plate 2, figs. $26,27,1816$.

Cellaria tenella Lamarck, Histoire naturelle des animaux sans vertèbres, ed. 1, 11, p. 135, $1816,1836$.

Cellaria tenella Blainville, Manuel d'Actinologie ou de Zoophytologie, 1834.

Cellaria tenella d'Orbigny, Paléontologie Française, Terr. Crétacés, vol. V, p. 28, 1850-52.

Nellia oculata Busk, British Museum Catalogue, I, p. 18, 1852.

Nellia oculata Smitt, Floridan Bryozoa, Kongl. Svenska Vetenskaps-Akademiens Handlingar, pt. XI, p. 3, 1873.

Nellia oculata McCoy, Prodromus of the Zoology of Victoria; decade V, p. 51, 1880.

Nellia oculata Haswell, On some Polyzoa from the Queensland Coast, Proceedings Linnean Society New South Wales, V, p. 36, 1881.

Membraniporina oculata Waters, Fossil Cheilostomatous Bryozoa from Muddy Creek, Victoria, Quarterly Journal Geological Society, tome XXXIX, p. 434, 1883.

Nellia oculata Busk, Report of the Voyage of H. M. S. Challenger, pt. XXX, p. 27, 1884.

Nellia oculata Hincks, On the Polyzoa and Hydroida of the Mergui Archipelago: Journal Linnean Society, Zoology, XXI, p. 121, 1887.

Nellia oculata MacGillivray, Catalogue of the Marine Polyzoa of Victoria, p. 15 and p. 34, 1887.

Farcimia oculata Waters, Bryozoa from New South Wales, etc., 1, 11, 111, Annals and Magazine Natural History (5), XX, p. 92, 1887.

Nellia tenella Jelly, A Synonymic Catalogue, p. 94, 1889.

Farcimia oculata MacGillivray, A Monograph of the Tertiary Polyzoa of Victoria, Transactions Royal Society of Victoria, vol. IV, p. 50, plate 6, figs. 5 to 7, 1895.

Farcimia tenella Canu, Bryozoaires tertiares des environs de Paris, Annales de Paléontologie, tome III, p. 20, plate 2 , figs. 36, 37, 1907.

Nellia tenella Levinsen, Morphologic and Systematic Studies on the Cheilostomatous Bryozoa, p. 120, plate I, fig. 13 (ovicell), 1909.

Farcimia oculata Waters, Marine Biology of the Sudanese Red Sea, Journal Linnean Society, Zoology, XXXI, p. 167, 1909.

Farcimia oculata Canu, Les Bryozoaires helvétiens de l'Égypte, Mémoires de l'Institut Egyptien, VI, p. 191, 1912.

Farcimia oculata Waters, Marine Fauna of British East Africa and Zanzibar, Proceedings Zoological Society of London, p. 489, plate LXvIr, figs. 8, 9, 1913.

Our small fragments are quite sufficient for the determination of this species. The dimensions of the opesium are not equal on the four sides, one of which is often larger than the other.

The authors are not in accord as to the name which should be given to this species. We have adopted that of Busk.

Occurrence.-Lower Miocene (Bowden horizon), Cercado de Mao (Bluff 3), Santo Domingo.

Geological distribution.-Lutetian of the environs of Paris (Canu); Helvetian of Egypt (Canu); Miocene of Australia (Waters).

This species also occurs in the recent seas off Florida (Smitt) and the Isle of St. Thomas (Levinsen).

Family OPESIULID E Jullien, 1888.

Genus FLORIDINA Jullien, 1881 .

Floridina pyripora, new species.

(Plate 1, Figure 2.)

Only two specimens of this species have been collected in the Leeward Islands. These are hardly sufficient for description of a new Floridina, for polymorphism is the rule in this genus; but we believe 
more specimens will prove this to be a good species. The polypidian convexity is little salient; the opesiules are large and poorly defined; the lateral apophyses are very little salient; the general aspect of the opesium is pyriform. The ovicell is endozoœcial, smooth, and salient.

Measurements. -Opesium (including opesiules): $h o=0.20 \mathrm{~mm}$., $l o=0.22$ mm.; zoœcium: $L z=0.48$ to $0.50 \mathrm{~mm}$., $l z=0.40$ to $0.44 \mathrm{~mm}$.

Floridina antiqua Smitt, 1872, a Recent species in the Gulf of Mexico, is marked by large lateral denticles and with small opesiules; its aspect is quite different and its zoarium is not incrusting.

Occurrence.-Oligocene (Antigua formation), rare at the Rifle Butts, Antigua, Leeward Islands (loc. No. 6854), T. W. Vaughan, collector, 1914. Oligocene (Anguilla formation), rare along the southwest side of Crocus Bay, Anguilla, Leeward Islands (loc. No. 6967), T. W. Vaughan, collector, 1914.

\section{Floridina fusifera, new species.}

(Plate 1, Figure 3.)

The zoarium is incrusting. The zoœcia are hexagonal; the cryptocyst is larger than the opesium; it is of little depth and is finely granulated; the opesium is trifoliate; the lateral apophyses are very salient; the opesiules are large and rounded; the polypidian convexity is very salient and convex. The onychocellarium is large, somewhat constricted laterally, and is provided with a very large orifice. Here and there are small fusiform avicularia.

Measurements.-Opesium: $h o=0.20 \mathrm{~mm}$., $l o=0.18$ to $0.20 \mathrm{~mm}$.; zocecium: $L z=0.50 \mathrm{~mm}$., $l z=0.40 \mathrm{~mm}$.; onychocellarium: opesium $=0.30$ by $0.20 \mathrm{~mm}$.; zoœcium $=0.60$ by $0.36 \mathrm{~mm}$.

There are only four zoøcia intact on the single zoarium obtained. The presence of small fusiform avicularia has appeared to us sufficient to justify the creation of this new species, this feature never having been observed in the genus.

Occurrence.-Oligocene (Antigua formation), rare at the Rifle Butts, Antigua, Leeward Islands (loc. No. 6854), T. W. Vaughan, collector, 1914.

Genus LUNULARIA Busk, 1884 .

Lunularia species undetermined.

(Plate 2, Figures 15, 16.)

The figured specimen represents a zoarial fragment of a new species difficult to classify generically. On account of its perforated internal side it could be a Lunularia. The zoccia on the external side have indeed the form of that of Lunularia, but the interzoøcial vibracula do not exist.

Occurrence.-Lower Miocene (Bowden horizon), Rio Gurabo (zone D), Santo Domingo. 
Family CALPENSIIDE Canu and Bassler.

Genus CALPENSIA Jullien, 1888.

Calpensia impressa Moll, 1803.

(Plate 1, Figure 11.)

Eschara impressa Moll, Die Seerinde aus der Ordnung der Pflanzenthiere, Wien, p. 57, plate 11, fig. 9, 1803.

Eschara nobilis Michelin, Iconographie zoophytologie, p. 329, plate 79, fig. 1, 1847.

Membranipora calpensis Busk, Catalogue of the Marine Polyozoa in the Collection of the British Museum, Cheilostomata, pt. 2, p. 60, plate 104, figs. 5, 6, 1854.

Micropora impressa Waters, On the Bryozoa of the Bay of Naples, Am. Mag. Nat. Hist. (5), III, p. 1230, 1879.

Micropora impressa Calvet, Bryozoaires marines des côtes de Co1se, Travaux de l'Institut de Zoologie de l'Université de Montpellier, ser. 2, mém. 12, p. 17, 1902.

Micropora impressa Canu, Bryozoaires fossils de terraines du Sud-ouest de la France, Bull. Soc. Géologique de France (4), X, p. 844, plate 16, fig. 6 (variety), 1910.

Micropora impressa Mme. Guerin Guanivet, Contribution a l'étude des Bryozoaires des côtes armoricaines, I, Travaux scientifique du Laboratoire de Concarneau, III, p. 5, plate $1,1911$.

The discovery of this species in America was a great surprise, since it has heretofore been noted only in the Mediterranean area, where its zoaria occur in great abundance, especially on the African coast. Our determination is nevertheless an exact one, as we possess so many specimens for comparison that we should not be mistaken.

The bibliography of this species given by Pergens, Jelly, and Waters is absolutely false, for they have confounded many distinct species; Canu noted five of them in 1911. In spite of its antiquity there are no undoubted references to the species other than those we have given above.

The zoarium may be incrusting or Eschara-like. We have never observed an ovicell; it may have none. The species therefore belongs to a special family with Microporina Levinsen, 1909; Diplodidymia Reuss, Calpensia Jullien, 1888, and Hemiseptella Levinsen, 1909.

Occurrence.-Oligocene (Antigua formation), rare in the Carlisle marl-pit, Antigua, Leeward Islands, T. W. Vaughan, collector, 1914, Locality No. 6873.

Geological distribution.-Helvetian of Brittany, France (Michelin); Sahelian of Oran (collection Canu); Sicilian of Italy (Neviani).

Habitat.-Mediterranean, Gibraltar, Corsica, Tuscany, Naples, Adriatic, Egean Sea, Tunis, Algeria, Morocco, Atlantic off Brittany.

It abounds at a depth of 25 to 30 meters and is very common at the depths of 75 to 100 meters.

\section{Genus HEMISEPTELLA Levinsen, 1909.}

Hemiseptella grandicella, new species.

(Plate 5, Figure 11.)

The following is a description of this species:

The zoarium incrusts shells. The zoœcia are large, elongate, ogival, distinct, separated by a furrow of little depth; the mural rim is narrow, little salient, round, finely granulated; the cryptocyst is large, flat, granulated; the opesium is elongated, elliptical, irregular, and non-symmetrical in the proximal portion. 
Measurements.-Opesium: $h o=0.40 \mathrm{~mm}$., $l o=0.25 \mathrm{~mm}$.; zoœcia: $L z=0.65$ to $0.70 \mathrm{~mm}$., $l z=0.35 \mathrm{~mm}$.

Affinities. - The group of inferior opesiular spines was certainly dissymmetrical; trace of the lateral spines is scarcely visible on our specimens.

This species differs from Hemiseptella denticulata Smitt, 1872, in the absence of nodosities in the interzoœcial angles and in the non-trifoliate opesium.

It differs from Hemiseptella tenuis Desor, 1848, in the larger micrometric measurements and in the more fragile and less numerous spines.

Occurrence.--Lower Miocene (Bowden marl), Bowden, Jamaica (rare).

\section{Hemiseptella lata, new species.}

(Plate 2, figure 4.)

The following is a description of this species:

The zoarium incrusts Metrarabdotos. The zoccia are distinct, little elongated, wide, subrectangular; the mural rim is thin. The opesium is elliptical or orbicular, never symmetrical; the cryptocyst is short, little deep, irregular; the opesiular indentations are represented by two lateral dissymmetric concavities and are often separated by a wide and serrate denticle.

Measurements.-Opesium: $h o=0.30 \mathrm{~mm}$., $l o=0.22$ to $0.30 \mathrm{~mm}$.; zoœcia: $L z=0.42 \mathrm{~mm}$., $l z=0.30$ to $0.32 \mathrm{~mm}$.

Affinities. - It is always difficult to characterize a species from the study of a single specimen. Exteriorly the zoœecia have the form of certain zoœeia observed in Acanthodesia savartii Savigny-Audouin, 1826; it differs from it in its non-symmetric opesium and in two opesiular sinuosities.

This species differs from Biflustra savarti Smitt, 1872, which is not its perhaps the species of Audouin, in the more constant development of cryptocyst and in the nature of its zoarium, which does not incrust algæ. The proximal denticle has been clearly observed on these zoœcia.

Occurrence.- Lower Miocene (Bowden horizon), Cercado de Mao (Bluff 3), Santo Domingo.

\section{Genus CUPULARIA Lamouroux, I821.}

\section{Cupularia umbellata Defrance, 1823 .}

(Plate 1, Figures 5 to 7; Plate 2, Figures 17 to 21.)

Discoporella denticulata Gabb and Horn, Monograph of the Fossil Polyzoa of the Secondary and Tertiary Formations of North America, Journal Academy of Natural Sciences of Philadelphia (2), V, p. 142, plate 20, fig. 25, 1862.

Cupularia umbellata Canu, Iconographie des Bryozoaires fossiles de l'Argentine, Anales del Museo Naçional de Buenos Aires, XVII, p. 275, plate $v$, figs. 4, 5, 1908. (See for complete bibliography.)

Cupularia umbellata Canu, Bryozoaires fossiles du Sud-ouest de la France, Bulletin de la Société Géologique de France (IV), IX, p. 448, 454, plate XvI, figs. 16, 17, 1909. (Regional bibliography.)

Cupularia lowei Norman, On the Polyzoa of Madeira, Journal Linnæan Society, XXX, p. 290, plate 37, figs. 7-12, 1909. 
Cupularia umbellata Canu, Étude comparée des Bryozoaires Helvétiens de l'Égypte avec les Bryozoaires vivants de la Mediterranée et de la Mer Rouge, Mémoire de l'Institut Egyptien, tome VI, fasc. III, p. 205, 1913.

Cupularia umbellata Canu, Contributions à l'étude des Bryozoaires fossiles, Bulletin Société Géologique France (IV), XIII, pp. 125, 126, 127, 1913.

Cupularia lowei Osburn, The Bryozoa of the Tortugas Islands, Florida, Carnegie Inst. Wash. Pub. No. 182, p. 194, 1914.

The fossils which are identified as above are rather well preserved and their determination is easy. The pores of the hydrostatic zoœcia are not radicular. We are ignorant as to why Norman, who is a great lover of archaic names, has not preserved the name of Defrance. The figures published by this author and by d'Orbigny are excellent and leave no doubt as to the identity of the two species.

The specimens from Santo Domingo are quite vigorous. They represent a variation that is remarkable in the size of the zoœcia and in the aspect of the inner side. The latter does not show the usual tuberose ribs and the tuberosities are equally distributed on the zoarial surface. The ancestrula is not always visible; it is often covered over by a normal zoœcium (fig. 19) or replaced by a special region in which the zoccia are arranged in contrary order (fig. 20).

Measurements. - Opesium: $h o=0.12 \mathrm{~mm}$., $l o=0.16 \mathrm{~mm}$.; zoøcium: $L z=0.44$ to $0.50 \mathrm{~mm}$., $l z=0.34 \mathrm{~mm}$.

Occurrence.-Lower Miocene (Gatun formation), Banana River, Costa Rica, D. F. McDonald, collector, 1911. Lower Miocene (Bowden horizon), Bowden, Jamaico, Cercado de Mao (Bluffs 2 and 3) and Rio Gurabo, Santo Domingo.

This species is almost always associated with Cupuladria canariensis Busk, 1859. Like the latter, it occurs in the lower Miocene (Alum Bluff formation) and also the later Miocene and Pliocene of the United States.

Geological distribution.-Aquitanian of Italy (Seguenza, Neviani), of Bordeaux (Canu); Burdigalian of Italy (Seguenza, Canu) of Bordeaux (Canu); Helvetian of Italy (Seguenza), of Touraine (Canu), of Bordeaux (Canu), of Maryland (Ulrich), of Egypt (Canu); Tortonian of Provence (Canu), of Italy (Seguenza); Plaisancian of England (Busk), of Italy (Manzoni); Astian of Italy (Neviani, Canu), of Provence (Canu); Sicilian of Italy (Neviani); Quaternary of Italy (Seguenza), of Argentina (Canu).

Habitat.-Mediterranean, Atlantic, Canary Islands, and Florida. It is common in the Gulf of Gascony in the Miocene, but it has now disappeared from this region.

The species has been dredged at a depth of 11 to 48 meters in America and from 81 to 113 meters in Madeira.

\section{CORYNOSTYLUS, new genus.}

No ovicell. The opercular valve articulates on two condyles. The zoœcia are club-shaped and provided with a gymnocyst. The zoarium is articulate. 
Genotype.-Corynostylus labiatus, new species. Lower Miocene.

This genus has no recent equivalent; but its structure is easy to interpret. The two condyles serve as a hinge for the strongly chitinized opercular valve. The lower part of the opesium placed below served evidently as passage for the opesiular fibers attached to the ectocyst. The deep cavity of the cryptocyst served as a hydrostatic apparatus for the entrance and exit of the polypide. Like most of the articulated genera, this one probably was fastened on large mobile algæ.

Corynostylus labiatus, new species.

(Plate 2, Figures 11 to 13.)

The following is a description of this species:

The zoarium is articulated and formed of long, regular segments. The segments are compressed, bilamellar, formed of three longitudinal rows of zoceia on each side. The zoccia are elongate, oval, distinct, rounded in front, narrowed behind, and are provided with a convex gymnocyst with large pores; the mural rim is thick, regular, granular. The opesium is elongate, oval, provided with a proximal, salient lip placed between two rounded opesiular indentations. The two condyles are quite salient. The cryptocyst is deep and smooth.

Measurements.-Opesium: $h o=0.12 \mathrm{~mm}$., $l o=0.10 \mathrm{~mm}$.; zoœcium: $L z=0.50$ $\mathrm{mm}$., $l z=0.26$ to $0.28 \mathrm{~mm}$.

Affinities.-The first zoccium of each segment is radicular; it gives rise to 3 polypidian zoœcia.

Occurrence.-Lower Miocene (Bowden horizon), Cercado de Mao (Bluff 3), Santo Domingo.

\section{Corynostylus ellipticus, new species.}

(Plate 2, Figures 8 to 10.)

The following is a description of this species:

The zoarium is articulated. The segments are formed of two longitudinal rows of zoccia placed only on one side of the zoarium. The zoœcia are distinct, club-shaped, with long, convex, and porous gymnocyst. The mural rim is thin and granular. The opesium is elliptical, elongate, surrounded by a salient rim; the two condyles are large and median. The cryptocyst is deep, smooth, and small.

Measurements.-Opesium: $h o=0.14 \mathrm{~mm}$., $l o=0.10 \mathrm{~mm}$.; zoœcium: $L z=0.50$ $\mathrm{mm}$., $l z=0.20$ to $0.22 \mathrm{~mm}$.

Affinities.-This species differs from Corynostylus labiatus in its unilamellar segments with only two zoccial rows and in the absence of a salient lip proximal to the opesium. Only the fragments figured have been found; they are extremely fragile.

Occurrence.-Lower Miocene (Bowden horizon), Cercado de Mao (Bluff 3), Santo Domingo. 


\section{Family THALAMOPORELLIDE.}

\section{Genus THALAMOPORELLA Hincks, 1887.}

Thalamoporella granulata Levinsen, r909.

(Plate 2, Figure 14.)

Thalamoporella granulata Levinsen, Morphological and Systematic Studies on the Cheilostomatous Bryozoa, p. 188, plate vi $a$, fig. 1, 2, plate vi, fig. 5, 1909.

Thalamoporella granulata Osburn, The Bryozoa of the Tortugas Islands, Florida, Carnegio Inst. Wash. Pub. No. 182, p. 197, fig. 8, 1914.

Measurements. -Opesium: $h o=0.16$ to $0.18 \mathrm{~mm}$., $l o=0.16$ to $0.18 \mathrm{~mm}$; zoœcium: $L z=0.80 \mathrm{~mm}$., $l z=0.50 \mathrm{~mm}$.

Affinities.-We possess only a small fragment consisting of two zoœcia; we are not certain, therefore, of our determination, as this has been made almost entirely on the micrometric measurements.

The opesium is oval, the point above; the cryptocyst is granulated; the mural rim has a width of $0.08 \mathrm{~mm}$. and is granulated transversely.

Occurrence.-Lower Miocene (Bowden horizon), Rio Cana, Santo Domingo.

Habitat.-Andaman or Nicobar Islands? (Levinsen); Tortugas Islands, Florida (Osburn).

\section{Thalamoporella biperforata, new species.}

(Plate 6, Figures 10 to 15.)

The following is a description of this species:

The zoarium is bilamellar. The zoœcia are elongate, distinct, rectangular; the mural rim is thin, salient, beveled, and bears two hollow tubercles on each side of the aperture. The cryptocyst is deep, flat, ornamented with large, widely spaced pores and with numerous small pores closely placed together; the opesiules are very large, far distant from the aperture, placed symmetrically, but very unequal in size. The apertura is transverse, oval; the proximal border is always concave and the polypidian tube is limited by two small lateral indentations. The reticulocellarium is large, quite elongate; its cryptocyst is perforated by two opesiules; the opesium bears two lateral denticles serving as pivot to the corneous onychocellarium.

Measurements.-Opesium of zoceium: $h o=0.10$ to $0.12 \mathrm{~mm} ., l_{0}=0.14 \mathrm{~mm}$; zoccium: $L z=0.54$ to $0.60 \mathrm{~mm}$., $l z=0.34$ to $0.40 \mathrm{~mm}$.; opesium of onychocellarium: $h o=0.24 \mathrm{~mm}$., $l o=0.12 \mathrm{~mm}$; onychocellarium: $L o=0.90 \mathrm{~mm}$, $l o=0.30 \mathrm{~mm}$.

Affinities.-The oral tuberosities are quite variable in size; they are often replaced by two fossettes.

This species is characterized by its onychocellarium, which resembles that of Thalamoporella granulata Levinsen, 1909, figured by Osburn, 1914. It differs, however, in the very different oval form of its aperture and in the presence of oral tuberosities.

In its tuberosities this species is quite close to Thalamoporella rozieri Savigny-Audouin, 1826. It differs from it in the form of its onychocellarium provided with two opesiules, which are not figured by Levinsen in the numerous drawings which he has given. 
Occurrence.-Lower Miocene (Bowden horizon), Cercado de Mao and Rio Cana, Santo Domingo, and Bowden, Jamaica.

Family STEGANOPORELLIDE Levinsen, 1909.

Genus STEGANOPORELLA Smitt, 1873 .

Steganoporella parvicella, new species.

(Plate 6, Figures 6 to 9.)

The following is a description of this species:

The zoarium is unilamellar, incrusting algæ or bryozoa. The zoœcia are distinct, elongate, separated by a shallow furrow; the mural rim is thin, salient, finely granular. The cryptocyst is finely porous; the opesium is irregular or semilunar, a little elongate; the polypidian tube forms a rectangular surface, salient and excentric between the two dissimilar opesiular indentations. The large zoœcia $(B)$ are provided with a large distal floor, and the polypidian tube is almost median.

Measurements.-Opesium of small zoœcia: $h o=0.34$ to $36 \mathrm{~mm}$., $l o=0.16$ to $0.30 \mathrm{~mm}$.; small zoœcia $(a): L z=0.50$ to $0.76 \mathrm{~mm}$., $l z=0.50 \mathrm{~mm}$.; opesium of large zoœecia $(b): h o=0.24$ to $0.30 \mathrm{~mm}$., $l o=0.36$ to $0.40 \mathrm{~mm}$.; large zoœcia $(B): L z=1.00$ to $1.10 \mathrm{~mm}$., $l z=0.44$ to $0.56 \mathrm{~mm}$.

Affinities.-The dimensions are quite variable, but they are always smaller than those of Steganoporella magnilabris Busk, which this species resembles in all its other characters.

Occurrence.-Lower Miocene (Bowden horizon), Cercado de Mao (Bluff 3), Santo Domingo, and Bowden, Jamaica.

\section{Family ASPIDOSTOMIDE Canu, 1908.}

Genus LABIOPORA Levinsen, I909.

No ovicell; distinct, raised margins; frontal wall of polypidian tube not quadrangular and not surrounded by projecting flanges. Polypide tube bilabiate, on either side connected with the lateral wall by a vertical calcareous lamina; multiporous septulæ.

Genotype.-Labiopora crenulata Levinsen, 1909, Recent.

\section{Labiopora miocenica, new species.}

(Plate 6, Figure 1.)

The following is a description of this species:

The zoarium is unilamellar. The zoccia are elongate, distinct, rectangular; the mural rim is quite thin, round. The cryptocyst is little deep, flat, and formed of a tremocyst superposed on an olocyst perforated with corresponding pores. The opesium is transverse, terminal, or placed at the base of a funnel, formed by the much-developed vestibular arch. The polypidian tube is visible, wide, median.

Measurements.-Opesium: $h o=0.10 \mathrm{~mm}$., $l o=0.24$ to $0.28 \mathrm{~mm}$.; zoœcium: $L z=0.50$ to $0.64 \mathrm{~mm}$., $l z=0.32$ to $0.34 \mathrm{~mm}$.

Affinities.-This new species differs from Labiopora crenulata Levinsen; 1909, in the wide form of the zoœcia and in its transverse opesium. The only fragment found has been figured.

Occurrence.-Lower Miocene (Bowden horizon), Rio Gurabo, Santo Domingo. 
Family CRIBRILINIDEE Hincks, I880.

Genus PUELLINA Jullien, 1886.

Puellina radiata carolinensis Gabb and Horn, 1862.

(Plate 1, Figure 12.)

Reptescharella carolinensis Gabb and Horn, Journal Academy Natural Science, Philadelphia, 5, p. 136, plate 19, fig. 18, 1862.

This variety is characterized by its smooth peristome, without tuberosities, and by the small canal of the avicularium, which is larger than in the type.

In reality the spines have not disappeared; on the perfect specimens they are still visible; but they never have the size and importance of those which decorate the type. The zoøcia are a little larger and have 16 costules.

Occurrence.-Jacksonian of South Carolina and Alabama; Vicksburgian of Alabama; Oligocene (Anguilla formation), southwest side of Crocus Bay Bluff, 125 feet above sea-level, Anguilla (loc. No. 6967); Oligocene (Antigua formation), Rifle Butts, Antigua (loc. No. 6854), T. W. Vaughan, collector.

\section{Family ESCHARELLIDE Levinsen, 1909. \\ Genus SCHIZOPODRELLA Canu and Bassler, 1917. \\ Schizopodrella (?) mutabilis, new species. \\ (Plate 6, Figures 3 to 5.)}

The following is a description of this species:

The zoarium is unilamellar, tubular; it incrusts the fine radicells of algæ. The zoccia are little distinct, elongate, elliptical; the frontal is little convex, surrounded by areolar pores and garnished with some large tremopores. The apertura is elongate, oval, with a wide rimule separated from the anter by two salient condyles.

Measurements.-Apertura: $h a=0.18$ to $0.20 \mathrm{~mm}$., $l a=0.12 \mathrm{~mm}$.; zocecium: $L z=0.70 \mathrm{~mm}$., $l z=0.34 \mathrm{~mm}$.

Affinities. - The very thick incrustation of the tremocyst renders the aspect of the species quite changeable and sometimes absolutely unrecognizable.

We have not discovered the ovicell, so the classification naturally remains doubtful.

Occurrence.-Lower Miocene (Bowden horizon), Cercado de Mao (Bluff 3), Santo Domingo.

Schizopodrella unicornis Johnston, 1847 .

Lepralia unicornis Johnston, History of British Zoöphytes, ed. 2, p. 320, plate 57, fig. 1, 1847.

Schizoporella unicornis Hincks, British Marine Polyzoa, p. 238, plate 35, figs. 1-5, 1880.

Schizoporella unicornis Jelly, A Synonymic Catalogue of Marine Polyzoa, p. 236, 1889. (General bibliography.)

Schizoporella unicornis Canu, Bryozoaires fossiles des Terrains du Sud-ouest de la France, Bulletin de la Société géologique de France, p. 516, 1906. (Bibliography.)

Schizoporella unicornis Osburn, The Bryozoa of the Tortugas Islands, p. 205, 1914. (American bibliography.)

Schizoporella subquadrata Ulrich and Bassler, Maryland Geological Survey, Miocene, p. 420, plate 114, fig. 1; plate 118, figs. 5, 6, 1904 . 
This species may easily be confused with Stylopoma spongites Pallas, 1766 ; it is distinguished from it by the wide, proximal sinus of its aperture and by the quite different form of its ovicell.

At Bowden we have found only a single specimen, but we are quite certain of its determination.

This recent species, which is abundant throughout the European Tertiary, is on the contrary very rare in America; but its geologic distribution there appears to be almost identical.

Occurrence.-Lower Miocene (Bowden marl), Bowden, Jamaica.

Geologic distribution.-In Europe since the Stampian; in America, Miocene of Maryland (Ulrich). We have also discovered it in the Miocene at Wilmington, North Carolina, and Muldrow's Mills, South Carolina.

Habitat.-Atlantic, Mediterranean.

Genus STYLOPOMA Levinsen, I909.

Stylopoma spongites Pallas, 1766.

(Plate 1, Figure 13.)

Cellepora informata Lonsdale, Report on the Corals from the Tertiary Formations of North America, Quart. Journ. Geol. Soc. London, I, p. 505, fig. 0, 1845.

Hippothoa spongites Smitt, Floridan Bryozoa, part I, Kongl. Svenska, Ventenskaps-Akademiens Handlingar, $X$, No. 11 , p. 42, plate virr, fig. $161,162,163,1872$.

Schizoporella informata Ulrich and Bassler, Maryland Geological Survey, Miocene, p. 419, plate 114, figs. 6-10, 1904.

Affinities and variations. - The specimen from the Anguilla formation certainly represents the narrow variation of this species. It is incrusting a sponge. At Bowden we have found only a single specimen.

The apertura is quite characteristic; the sinus is rectilinear and quite narrow; the tongue of the operculum which covers it is rigid.

This species is one of the more common of the American species of the Miocene and Pliocene. Its geographic distribution was limited by the equator and $40^{\circ}$ parallel. Like Callopora tenella, it is now living in the waters off Florida.

Occurrence.-Lower Miocene (Bowden marl), Bowden, Jamaica (very rare); Oligocene (Anguilla formation), southwest side of Crocus Bay, Anguilla, Leeward Islands, T. W. Vaughan, collector, 1914, loc. No. 6894 .

Habitat.-Florida (Smitt, Osburn).

\section{Genus STEPHANOSELLA Canu and Bassler, 1917. \\ Stephanosella biaperta Michelin, I842.}

(Plate 1, Figures 16 to 18.)

Eschara biaperta Michelin, Iconographie zoophytologie, p. 330, 1842.

Hippothoa biaperta Smitt, Floridan Bryozoa, pt. II, Kongl. Svenska, Vetenskaps-Akad. Handlingar, X, p. 46, plate vin, figs. 173-176, 1873.

Schizoporella biaperta Robertson, The Incrusting Cheilostomatous Bryozoa of the West Coast of North America, Univ. California Pub. IV, No. 5, p. 287, plate 19, fig. 41, 1908. (General bibliography.)

Schizoporella biaperta Osburn, Bryozoa of Tortugas Islands, Carnegie Inst. Wash., Pub.No. 182, p. 207, 1914. (Regional bibliography.) 
The fossil specimens from Anguilla closely resemble Smitt's figures 173 and 175.

American occurrence.-Oligocene (Anguilla formation), rare along the roadside, descent to Crocus Bay from Valley, Anguilla, Leeward Islands, loc. 6893, T. W. Vaughan, collector, 1914.

Geological distribution.-Helvetian of Italy (Seguenza), of Sardinia (Neviani), of Touraine (Michelin); Zanclean of Italy (Seguenza); Sahelian of Oran (collection Canu); Plaisancian of England (Busk), of Italy (Manzoni); Sicilian of Italy (Neviani, Waters); Quaternary of Italy (Neviani); Miocene of Australia (Waters, MacGillivray).

Habitat.-Very cosmopolitan, even to the polar regions. It has been dredged to a depth of 245 meters, but in Florida it lives at a depth of 15 to 97 meters.

\section{Genus GEMELLIPORELLA Canu and Bassler.}

Gemelliporella punctata, new species.

(Plate 5, Figures 7 to 9.)

The following is a description of this species:

The zoarium is free, cylindrical, bifurcated. The zoœcia are very little distinct, elongate, convex; the frontal is granular and surrounded with areolar pores and is sometimes covered with punctations of pleurocystal origin. The aperture is oval, elongate, formed of a large semilunar anter and of a wide proximal sinus. The ovicell is deeply embedded in the distal zoœcium, little salient, closed by the operculum, ornamented by an orbicular and very fragile frontal area.

Measurements.-Apertura: $h a=0.17 \mathrm{~mm}$., $l a=0.10 \mathrm{~mm}$.; zoœcia: $L z=0.55$ $\mathrm{mm}$., $l z=0.40$ to $0.45 \mathrm{~mm}$.

Affinities. - The punctations of the frontal are quire variable; there is not a single zoœcium similar to another. In a better preserved state we think that each zoccium is surrounded with areolar pores irregular in size and spacing. The frontal is a thick and compact olocyst, covered by a pleurocyst which is granular or punctured with large pores which do not perforate the zoœcial walls. Unfortunately we have not been able to confirm this exterior aspect by sections.

Occurrence.-Lower Miocene (Bowden marl), Bowden, Jamaica (rare).

\section{Genus HIPPOMENELlA Canu and Bassler, 1917.}

Hippomenella infratelum, new species.

(Plate 6, Figure 2.)

The following is a description of this species:

The zoarium is a narrow Eschara borne on an expanded base. The zoœcia are elongate, distinct, elliptical; the frontal is convex, surrounded by a line of small areolar pores and formed of a pleurocyst very finely granulated. The apertura is elliptical, elongate, with two very small cardelles. The avicularium is salient, elliptical, with pivot placed on the line of pores in the lower part of the zoœcium.

Measurements.-Apertura: $h a=0.16$ to $0.20 \mathrm{~mm}$., $l a=0.14 \mathrm{~mm}$.; zoøcium: $L z=0.60$ to $0.70 \mathrm{~mm}$., $l z=0.40$ to $0.50 \mathrm{~mm}$. 
Affinities.-The only specimen found has been figured. The species is absolutely characterized by its elliptical avicularium placed inferiorly, a character which does not exist in the other species of the genus. We have observed a rather rare case of regeneration of a zoccium by an avicularium $(z r)$.

Occurrence.-Lower Miocene (Bowden horizon), Cercado de Mao (Bluff 3), Santo Domingo.

\section{Genus HIPPOPORINA Neviani, 1895.}

Hippoporina lata Smitt, 1862.

(Plate 1, Figure 14.)

Gemellipora lata Smitt, Floridan Bryozoa, pt. I, Kongl. Svenska Vetenskaps-Akademiens Handlinger, X, No. 11, p. 36, plate 7, fig. 157, 1872.

This Recent species was described from specimens from the Floridan waters and the species itself is confined to this region. A very mediocre fossil specimen of doubtful determination has been found in the strata of Antigua.

Occurrence.-Oligocene (Antigua formation), Rifle Bútts, Antigua, Leeward Islands, T. W. Vaughan, collector, 1914, loc. No. 6854.

\section{Family SMITTINIDE Levinsen, I909.}

Genus SMITTINA Norman, 1903.

Smittina (?) brevis, new species.

(Plate 2, Figure 22.)

The following is a description of this species:

The zoarium is bilamellar, with fronds somewhat compressed. The zoocia are little distinct, elongate, elliptical; the frontal is convex and very short, and it bears below a large salient avicularium with rounded beak. The apertura is elliptical and deep. The ovicell is globular, little salient, ornamented by a fragile circular area; it opens into the peristomie.

Affinities.-This species is quite unique and difficult to classify. We have put it in Smittina because the ovicell opens into the peristomie formed by the thickening of the frontal walls; but it does not really belong to this genus, because it has no lyrula nor oral avicularium and because the apertura is not semilunar.

Occurrence.-Lower Miocene (Bowden horizon), Cercado de Mao, Santo Domingo.

\section{Genus PORELLA Gray, 1848 .}

Porella bella Busk, 1860 .

(Plate 1, Figure 15.)

Lepralia bella Busk, Quarterly Journal Microscopical Science, VIII, plate xxvir, figs. $2,3,1860$.

Escharella landsborovi Smitt, Floridan Bryozoa, pt. II, Kongl. Seven. Vet. Akad. Hand., XI, No. 3, p. 60, plate $x$, figs. 201, 202, 1873.

Smittia bella Hincks, British Marine Polyzoa, p. 352, plate 42, figs. 9, 10, 1880. 
We are not certain that Busk's species is identical with that of Smitt, as the former author represents it, but evidently the characters of the Antigua fossil, although poorly preserved, are in harmony with Smitt's figures. The measurements of this fossil are: Apertura: $h a=0.16 \mathrm{~mm}$., $l a=0.20 \mathrm{~mm}$.; zoœcia; $l z=0.90 \mathrm{~mm}$., $l z=0.70 \mathrm{~mm}$.

Occurrence.-Oligocene (Antigua formation), Rifle Butts, Antigua, Leeward Islands.

Habitat.-Shetland Islands, waters off Florida (185 meters).

Genus RHAMPHOSTOMELLA Lorenz, 1886.

Rhamphostomella laticella, new species.

(Plate 5, Figure 12.)

The figured specimen is the only one found; it is unfortunately incomplete and worn and does not permit a detailed description. It incrusts a shell; the areolar costules are rare or little visible. The oral avicularium is quite large, oblique, the point directed towards the bottom.

Occurrence.--Lower Miocene (Bowden marl), Bowden, Jamaica (very rare).

\section{Genus RHYNCHOZOON Hincks, 1891.}

Rhynchozoon vaughani, new species.

(Plate 2, Figure 23; Plate 4, Figures 1, 2.)

The following is a description of this species:

The zoarium is unilamellar. The zoœcia are large, distinct, hexagonal or claviform; the frontal is smooth, convex, surrounded by a line of small scattered areolar pores. The apertura is large, suborbicular, with a wide proximal rimule; the peristomie is deep and widened; the very irregular peristome bears some large tubercles; the false rimule is compressed between two large tuberosities, one of which bears an oral avicularium transversely arranged.

Measurements.-Apertura: $h a=($ ?), $l a=0.20 \mathrm{~mm}$.; zoœcia: $L z=0.60 \mathrm{~mm}$., $l z=0.50 \mathrm{~mm}$.

Affinities.-This species differs from Rhynchozoon solidum Osburn, 1914, which it much resembles, in its much larger micrometric measurements and in the absence of the small frontal avicularium.

Occurrence.-Lower Miocene (Bowden horizon), Cercado de Mao (Bluff 3), Santo Domingo (very rare).

Family ADEONIDE Jullien, 1903.

Genus ADEONA (Lamouroux, 1816) Levinsen, 1909.

Adeona porosa, new species.

(Plate 6, Figures 22, 23.)

The following is a description of this species:

The zoarium is free, bilamellar. The zoccia are little distinct, very elongate, separated by a hardly visible, salient thread; the frontal is porous, little 
convex, surrounded by areolar, parietal pores, of which one is larger than the others. The ascopore is large, orbicular, median. The apertura and peristomice are semilunar, with the proximal border somewhat concave. The gonœcia have two very large symmetrical, areolar pores and irregular, oral gibbosities. The avicularian zoœcia have their opesia arranged on the lower part of a pyriform area, calcified and deep.

Measurements.-Apertura: $h a=0.12 \mathrm{~mm}$., $l a=0.12 \mathrm{~mm}$.; zoœecia: $L z=0.60$ $\mathrm{mm}$., $l z=0.30 \mathrm{~mm}$.

Affinities.-As we possess only the figured fragment, the study of this species is necessarily incomplete. The species is very peculiar one, for there is no other one provided with a porous frontal and oral gibbosities at the gonœcia.

It is to be noted that this genus has disappeared from the waters of the Gulf of Mexico. In the family Adeonidæ, only the genus Adeonellopsis has survived.

Occurrence.-Lower Miocene (Bowden horizon), Cercado de Mao (Bluff 3), Santo Domingo.

\section{Adeona heckeli Reuss, 1847 .}

Cellepora heckeli Reuss, Die fossilen Polyparien des Wiener Tertiär-beckens, Haidinger's naturwissenschaftliche Abhandlungen, II, p. 85, plate 10, fig. 10, 1847.

Lepralia violacea Johnston, A History of the British Zoophytes, p. 325, plate 57, fig. 9, 1849.

Multiporina umbilicata Gabb and Horn, Monograph of the Fossil Polyzoa of the Secondary and Tertiary Formations of North America, Journal Academy of Natural Sciences of Philadelphia (2), V, p. 145, plate 20, fig. 27, 1862.

Microporella violacea Hincks, History of the British Marine Polyzoa, p. 216, 1880.

Adeona violacea Osboin, The Bryozoa of the Tortugas Islands, Florida. Carnegie Inst. Wash. Pub. No. 182, p. 199, 1914.

Of this species we have found only a single specimen in the Bowden marl which is moderately well preserved.

This fossil, rather abundant in the European Miocene and Pliocene, is, on the contrary, quite rare in America.

Occurrence.-Lower Miocene (Bowden marl), Bowden, Jamaica.

Geological distribution.-European Miocene and Pliocene; Miocene of North Carolina and Virginia; Pliocene of Shell Creek, Florida.

Habitat.-Atlantic and Mediterranean. In Florida this species was dredged at a depth of 56 to 97 meters. Osburn collected it at a depth of 8 to 29 meters in the region of the Tortugas. Finally Verrill noted it from the Bermudas.

Family HIPPOPODINIDE Levinsen, 1909.

Genus METRARABDOTOS Canu, rgr4.

Metrarabdotos colligatum, new species.

(Plate 4, Figures 3 to 12.)

The following is a description of this species:

The zoarium is free, bilamellar, attached to algæ by a small, expanded base and bent upward like a crank; the fronds are large, bifurcated, but narrow. The zoccia are distinct, separated by a salient thread, long and narrow; the 
frontal is smooth, convex, surrounded by a line of large areolar pores often separated by short costules. The apertura is suborbicular; the peristomice is oval with a proximal pseudorimule. There are sometimes two quite inconstant, small, oral avicularia. The ovicell is endozoœcial, enormous, borne by a considerably enlarged zoœcium; the frontal is garnished with radiating and granulated costules.

Measurements.-Young zoœcia: apertura, $h a=0.14 \mathrm{~mm}$., la=0.12 $\mathrm{mm}$; zoœcia: $L z=0.60 \mathrm{~mm}$., $l z=0.28$ to $0.30 \mathrm{~mm}$.; old zoœcia: apertura, $h a=0.24$ mm., $l a=0.16 \mathrm{~mm}$.; zoœcia: $L z=0.70 \mathrm{~mm}$., $l z=0.24$ to $0.30 \mathrm{~mm}$.

Affinities.-The genus Metrarabdotos contains more species in America than in Europe. The present species differs from Metrarabdotos moniliferum Milne-Edwards, 1836, common in the French Miocene, in its granulated costules on the ovicell, in the absence of a pseudo lyrule at the peristomice, and in the absence of oral avicularia.

It differs from Metrarabdotos grandis of the Vicksburgian, which also forms large fronds, in its greater zoœcial width, and in much less deep intercostular spaces of the ovicell.

The species is quite variable and we have figured the principal variations.

Occurrence.-Lower Miocene (Bowden horizon), Cercado de Mao (Bluff 3), and Rio Cana (Zone H), Santo Domingo.

\section{Metrarabdotos lacrymosum, new species.}

(Plate 3, Figures 1 to 10.)

The following is a description of this species:

The zoarium is free, bilamellar, bifurcated, narrow, with rectangular fronds, and fastened by a little expanded base. The zoccia are distinct, little elongate, rectangular, surrounded by large areolar pores more or less separated by the costules. The apertura is oblique, semielliptical, divided in front by a rounded and perforated sinus. The ovicelled zoœcia are quite wide; the ovicell is endozocecial; it is little salient, finely punctate, and ornamented with interareolar costules. On each side of the apertura there are two large, triangular, salient avicularia with their point directed above.

Measurements.-Apertura: $h a=0.18 \mathrm{~mm}$., $l a=0.14 \mathrm{~mm}$.; zoøecium: $L z=0.70$ to $0.74 \mathrm{~mm}$., $l z=0.28$ to $0.30 \mathrm{~mm}$.

Affinities.-The characteristics of this species are the two large, oral avicularia which hang from each side of the aperture like two large tears. They are very irregular.

This species differs from Metrarabdotos colligatum from the same geological horizon in its little-expanded and non-prehensile base, in its non-claviform fronds, and in the presence of large, oral avicularia.

It differs from Metrarabdotos moniliferum Milne-Edwards, 1838, in its much less costulated ovicell and in the absence of a spine in the oral sinus.

Occurrence.-Lower Miocene (Bowden marl), Bowden, Jamaica (common). 
Genus BRACEBRIDGIA MacGillivray, 1886.

Bracebridgia deformis, new species.

(Plate 3, Figures 11 to 16.)

The following is a description of this species:

The zoarium is free, bilamellar, compressed, bifurcated. The zoceia are distinct, elongate, separated by a deep furrow, claviform or elliptical; the peristomice is oval or elliptical; an oblique avicularium is buried in the peristomie; the apertura (visible only from the interior) is semilunar; the frontal is surrounded by areolar, parietal pores, and on the old zoceia it bears a large pore which does not perforate the wall.

Measurements.-Peristomice: hpie $=0.15 \mathrm{~mm}$., lpie $=0.12 \mathrm{~mm}$.; zoœcium: $L z=0.45$ to $0.60 \mathrm{~mm}$., $l z=0.25$ to $0.30 \mathrm{~mm}$.

Affinities.-This species has the exterior aspect of an Adeonellopsis. The large frontal pore, however, is not a perforated area; it is invisible in the interior, and its nature is unknown. The few specimens which we have studied were, it is true, rather poorly preserved.

The peristomial avicularium is rarely visible at the exterior; it is, on the contrary, quite constant in the interior. This interior is that of Bracebridgia; it is, therefore, indeed in this genus that it must be classified, but it is a deformed Bracebridgia.

The presence of a large frontal pore clearly characterizes this species, and it clearly differentiates it from the other known species of the same genus.

Occurrence.-Lower Miocene (Bowden marl), Bowden, Jamaica (rare).

\section{Family CELLEPORIDÆ Busk, 1852.}

Genus HOLOPORELLA Waters, 1909 .

Holoporella albirostris Smitt, 1873 .

(Plate 1, Figure 19; Plate 7, Figures 9 to 14.)

Discopora albirostris Smitt, Floridan Bryozoa, pt. II, Kongl. Svenska. Vetenskaps-Akademiens Handlingar, XI, No. 4, p. 70, plate 12, figs. 233 to 239, 1873.

Cellepora albirostris Jelly, A Synonymic Catalogue of the Recent Marine Bryozoa, p. 45, 1889. (See for complete bibliography.)

Holoporella albirostris Osburn, Bryozoa of Tortugas Islands, Carnegie Inst. Wash. Pub. No. 182 , p. $215,1914$.

Of the two specimens of this species which have been collected at Panama and at Anguilla one corresponds to Smitt's figure 237 and the other to figure 238.

This species is one of the more common among the American fossils. The Recent specimens are quite variable in aspect; the polymorphism of the fossils is also quite remarkable on account of alterations.

The avicularian beak is not as complete and well-developed as on the immersed zoœcia. It is quite often absent on the superficial zoœcia.

The interzoccial avicularium is spatulate; its distribution on the zoaria is very irregular.

The frontal is an olocyst bordered with areolar pores. 
Occurrence.- Oligocene (Emperador limestone), old quarry one-third mile north of west of Empire, Panama Canal Zone, D. F. MacDonald and T. W. Vaughan, collectors, 1911 (loc. No. 6016); Oligocene (Anguilla formation), southwest side of Crocus Bay, Anguilla, Leeward Islands, T. W. Vaughan, collector, 1914 (loc. No. 6894); lower Miocene (Bowden marl), Bowden, Jamaica (common).

Geological distribution.-Miocene of Australia and New Zealand (Waters).

Habitat.-Atlantic off Florida; Pacific off Australia. Specimens have been dredged off Australia to a depth of 121 meters. Smitt in Florida has discovered them between 40 and 56 meters, but Osburn states that the species abounds at a depth of 24 meters.

\section{Family CONESCHARELLINIDE Levinsen, 1909.}

Genus STICHOPORINA Stoliczka, 1862.

Stichoporina tuberosa, new species.

(Plate 1, Figures 20 to 23; Plate 6, Figures 16 to 19 ; Plate 7, Figures 1 to 8.)

The following is a description of this species:

The zoarium is free, conical, hollow, with very thick walls. The peristome is salient, ornamented with small tuberosities; it bears one or two small elliptical avicularia with bar or denticles. The apertura is elliptical, elongated, hidden at the base of a short peristomie; it is formed of a large semielliptical anter and of a small concave poster, separated by two small, salient cardelles. The ovicell is large, somewhat salient, convex; it is hyperstomial and always closed by the operculum. A salient, elliptical avicularium, with two denticles serving as pivot, is placed at the base of each zoœcium; it deforms the adjacent peristomes. The inner side is tuberose and bears very large pores arranged in quincunx. On the lower face there are large pores surrounded by very small ones.

Measurements.-Apertura: $h a=0.14 \mathrm{~mm}$., $l a=0.10 \mathrm{~mm}$.; zoœcium: $L z=0.30$ $\mathrm{mm}$., $l z=0.30 \mathrm{~mm}$.; opesium of avicularium: $h o=0.10 \mathrm{~mm}$., $l o=0.06 \mathrm{~mm}$;. avicularium: $L a v=0.20 \mathrm{~mm}$., $l a v=0.12 \mathrm{~mm}$.

This is a very elegant species characterized by its peristomial tuberosities. The ancestrula is visible only in the interior of the zoarium; it is covered exteriorly by the first zoœcia. All the zoœcia are separated from each other by small canals which appear to end in the large, inferior pores.

The oral tuberosities are hollow. The pores of the internal cavity are avicularia of which the pivot is formed by two denticles; they are analogous with those of the external face (inferior).

The internal face (and upper) bears also large cavities which we believe to be hydrostatic cavities; but it must be proved that the ectocyst is resistant enough to confine an equal amount of water. We must suppose also that these cavities are intended to counterbalance the irregularities of calcification and to assure the perfect equilibrium of the zoarial system. 
This species must not be confounded with Mamillopora cupula Smitt, 1872. It differs from it in its ovicell, which is not bilobate, and in its ovarian zoœcia, which are not larger than the others.

Occurrence.-Lower Miocene (Gatun formation), Banana River, Costa Rica, D. F. McDonald, collector, 1911; lower Miocene (Bowden horizon), Rio Gurabo (zone D), Rio Cana (zone I), and Cercado de Man, Santo Domingo; Bowden, Jamaica.

\section{Order CYCLOSTOMATA Busk.}

\section{Family TUBULIPORIDE Johnston, 1838.}

Genus IDMONEA Lamouroux.

Idmonea milneana d'Orbigny, 1839.

(Plate 6, Figures 20, 21.)

Idmonea milneana d'Orbigny, Voyage dans l'Amérique méridionale, V, pt. 4, p. 20, plate 9 , figs. 17 to 21,1839 .

Idmonea grateloupi d'Orbigny, Paléontologie française, Bryozoaires crétacées, p. 729, 1852.

Idmonea milneana Smitt, Floridan Bryozoa, p. 8, plate III, figs. 14-19, 1872.

Idmonea milneana Canu, Bryozoaires tertiares des environs de Paris, Annales de Paléontologie, III, p. 125, plate 14, figs. 11-13, 1908. (Cites bibliography.)

Idmonea milneana Canu, Bryozoaires du Sud-Ouest de la France, Bulletin de la Société Géologique de la France (4), VIII, p. 386, I, p. 451, 1908.

Our small specimen is not very well preserved, but we feel perfectly certain of it, because we know all its fossil variations. It is evident, however, that such a determination is always subject to revision.

Occurrence.-Lower Miocene (Bowden horizon), Cercado de Mao, Santo Domingo.

Geological distribution.-Ypresian of England (Gregory); Lutetian of Bavaria (Koschinsky), of Paris (Canu), of the Ariege (Canu); Auversian of Biarritz (Canu); Latdorfian of Latdorff (Stoliczka); Stampian of Germany (Reuss); Tortonian of Austria-Hungary (Reuss); Sicilian of Italy (Seguenza); Quaternary of Italy (Seguenza).

Habitat. - Cosmopolitan in both hemispheres. In Florida it has been dredged between 26 and 109 meters. 


\section{DESCRIPTION OF PLATES.}

\section{Plate 1.}

Fig. 1. Callopora dumerilli var. lata, n. var. Portion of the incrusting zoarium, $\times 20$. Most of the zooecia have a single avicularium in front of the opesium. Oligocene (Anguilla formation). Southwest side Crocus Bay Bluffs, Anguilla, Leeward Islands.

Fra. 2. Floridina pyripora, n. sp. Surface of the type, $\times 20$, showing the large, poorly defined opesiules and the pyriform aspect of the opesium. Oligocene (Antigua formation), Rifle Butts, Antigua, Leeward jslands.

Fig. 3. Floridina fusifera, n. sp. The type specimen, $\times 20$, exhibiting large, rounded opesiules and prominent polypidian convexity in the few zoccia intact. Oligocene (Antigua formation), Rifle Butts, Antigua, Leeward Islands.

Fig. 4. Ogivalina mutabilis, n. sp. The type specimen, $\times 20$, with large irregular opesia, small ovicell, small gymnocyst, and one zooecium with a fusiform avicularium. Oligocene (Anguilla formation), Crocus Bay Hill, Anguilla, Leeward Islands.

Fig 5-7. Cupularia umbellata Defrance, 1823. (See also plate 2, figs. 17-21.) (5) Two zoaria, natural size; (6) celluliferous convex surface, $\times 20$; (7) concave surface, $\times 20$. Lower Miocene (Gatun formation), Banana River, Costa Rica.

Figs. 8-10. Cupuladria canariensis Busk, 1859. (8) Two zoaria, natural size; (9) celluliferous convex surface, $\times 20$; (10) concave surface, $\times 20$. Lower Miocene (Gatun formation), Banana River, Costa Rica.

Fra. 11. Calpensia impressa Moll, 1803. Surface of an incrusting zoarium, $\times 20$. Oligocene (Antigua formation), Carlisle marl-pit, Antigua, Leeward Islands.

FIg. 12. Puellina radiata carolinensis Gabb and Horn, 1862. Gabb and Horn's illustration of this variety. Eocene (Jacksonian) of South Carolina.

Fic. 13. Stylopoma spongites Pallas, 1766. Several zoccia, much enlarged (Smitt's figures of Hippothoa spongites). Recent, Gulf of Mexico.

FIG. 14. Hippoporina lata Smitt, 1862. View of several zoccia much enlarged (after Smitt). Recent, Gulf of Mexico.

Fig. 15. Porella bella Busk, 1860. Smitt's illustration of Escharella landsborovi. Recent, Gulf of Mexico.

Frgs. 16, 17. Stephanosella biaperta Michelin, 1842. Two views of this species (after Smitt). Recent, Gulf of Mexico.

Fra. 18. Photograph, $\times 20$, of a specimen from Anguilla. Oligocene (Anguilla formation), Crocus Bay Hill, Anguilla, Leeward Islands.

FIg. 19. Holoporella albirostris Smitt, 1873. (See also plate 7, figs. 9-14.) Several zoœcia much enlarged (after Smitt). Recent, Gulf of Mexico.

Figs. 20-23. Stichoporina tuberosa, n. sp. (See also plate 6, figs. 16-19, plate 7, figs. 1-8.) (20) Two zocecia natural size; $(21,22)$ two views, $\times 20$, of the convex, celluliferous side; (23) photograph of the concave side, $\times 20$. Lower Miocene (Gatun formation), Banana River, Costa Rica.

\section{Plate 2.}

Fra. 1. Membranipora vaughani, n. sp. Portion of the incrusting zoarium, $\times 15$, showing th large interopesial denticles. Lower Miocene (Bowden horizon), Cercado de Mao, Santo Domingo.

Frgs. 2, 3. Acanthodesia savarti forma monilifera, n. sp. The hollow cylindrical zoarium, natural size and $\times 20$. The beaded structure of the mural rim is apparent. Lower Miocene (Bowden horizon), Cercado de Mao, Santo Domingo.

Fra. 4. Hemiseptella lata, n. sp. Part of the incrusting type specimen, $\times 15$, with some zoccis showing the characteristic inferior denticle. Lower Miocene (Bowden horizon), Cercado de Mao, Santo Domingo.

Figs. 5-7. Nellia oculata Busk, 1852. (5) Normal zoœcia with tubercles complete, $\times 19 ;(6)$ fragment showing large zoœcia, $\times 19$, the tubercles are replaced by pores; $(7)$ view of fragment, $\times 19$, showing two sides of the zoarium. Lower Miocene (Bowden horizon), Cercado de Mao, Santo Domingo.

Figs. 8-10. Corynostylus ellipticus, n. sp. (8) Several fragments of the articulated zoarium, natural size; (9) anterior face of zoarium, $\times 19$; (10) posterior face, $\times 19$. Lower Miocene (Bowden horizon), Cercado de Mao, Santo Domingo.

Figs. 11-13. Corynostylus labiatus, n. sp. (11) Complete segment of the articulated bilamellar zoarium, natural size; (12) photograph of the same, $\times 19$, the salient opesial lip is shown; (13) section, $X 15$, exhibiting the interior of the zoccia in the middle row and a longitudinal section in the outer rows. Lower Miocene (Bowden horizon), Cercado de Mao, Santo Domingo.

Fig. 14. Thalamoporella granulata Levinsen, 1909. Small fragment, $\times 15$, identified with this Recent species. Lower Miocene, Rio Cana, Santo Domingo. 
Plate 2-continued.

Figs. 15, 16. Lunularia species. Outer and inner sides of a fragment, $\times 15$. Lower Miocene (Bowden horizon), Rio Cana, Santo Domingo.

Figs. 17-21. Cupularia umbellata Defrance, 1828. (See also plate 1, figs. 5-7.) (17) Zoaria, natural size; (18) photographs of the inner tuberous side, $X 25 ;(19)$ ancestrular region, $\times 19$, in which the ancestrula is covered over by a normal zoœecium; (20) ancestrular region of another zoarium, $\times 19$; the zoccia are arranged alternately and in inverted order; (21) another view of the ancestrular region, $\times 19$; here the ancestrula is a membraniporoid zoœcium. Lower Miocene (Bowden horizon), Cercado de Mao, Santo Domingo.

Fic. 22. Smittina ? brevis, n. sp. Surface of the bilamellar zoarium, $\times 15$. Lower Miocene (Bowden horizon), Cercado de Mao, Santo Domingo.

Fig. 23. Rhynchozoon vaughani, n. sp. (See also plate 4, figs. 1, 2.) A small fragment, $X 15$, Lower Miocene (Bowden horizon), Cercado de Mao, Santo Domingo.

\section{Plate 3.}

Figs. 1-10. Metrarabdotos lacrymosum, n. sp. (1) A group of fragments, natural size; (2) fragment, $\times 4.5$, showing the little-expanded base; (3) another fragment, $\times 4.5$; (4) a worn branch, $\times 15$; the avicularia are absent or little apparent; (5) surface, $\times 15$, showing salient peristomes and larger triangular avicularia; $(6)$ worn zoarial fragment, $\times 20$; (7) ordinary zoceia of a branch, $\times 15$, with short, pointed, triangular avicularia; (8) ordinary zocecia, $\times 15$, with long avicularia; (9) branch, $\times 15$, with ovicelled zoœcia; the ovicell is slightly costulated and its frontal is granulose; $(10)$ ovicelled zoccia, $\times 15$, with the ovicell not costulated. Lower Miocene (Bowden marl), Bowden, Jamaica.

Frgs. 11-16. Bracebridgia deformis, n. sp. (11) Fragments, natural size; (12) the usual aspect of the zoceia, $\times 15$; the large frontal pore does not perforate the wall; $(13)$ zocecia at the base of a zoarium, $\times 15$; (14) zoccia, $\times 15$, with the large frontal pore wanting; (15) zoœcia, $\times 15$, with the peristomial avicularium slightly visible; (16) interior of zoccia, $X 15$; the peristomial avicularium is visible, but the frontal pore does not perforate the zoœcial wall. Lower Miocene (Bowden marl), Bowden, Jamaica.

\section{Plate 4.}

Figs. 1, 2. Rhynchozoon vaughani, n. sp. (See also plate 2, fig. 23.) (1) The unilamellar zoarium, $\times 15$, showing young condition in which the zoœcia are distinct; (2) old condition of zoarium, $\times 15$; the zoccia are indistinct and not oriented. Lower Miocene (Bowden horizon), Cercado de Mao, Santo Domingo.

Figs. 3-12. Metrarabdotos colligatum, n. sp. (3-5) Different aspects of the base of the zoarium, $\times 4.5$; (6) three fragments, natural size, preserving base; (7) portion of zoarial surface, $\times 15$, with two ovicells preserved; $(8)$ broad zoccia, $\times 15$, characteristic of the aged condition; (9) base of a zoarium, $\times 15$, showing calcification and disappearance of the apertures; (10) narrow zoœcia, $\times 15$, of youthful condition; (11) normal zoœcia, $\times 15$; (12) longitudinal section, $\times 15$, showing the interior of the zoccia. Lower Miocene (Bowden horizon), Cercado de Mao, Santo Domingo.

\section{Plate 5.}

Frgs. 1-5. Acanthodesia savarti forma texturata Reuss, 1846. (1) Fragments of the unilamellar, hollow cylindrical zoarium, natural size; (2) zoccia, $\times 15$, with traces of delicate spines in the opesium; (3) inner side of zoarium, $\times 15$, showing rectangular form of zoøcia; (4) zoœcia, $\times 15$, with a distinct rim around the opesium; (5) another surface, $\times 15$, showing the large size of the first zoccium of a new row. Lower Miocene (Bowden marl), Bowden, Jamaica.

Fra. 6. Conopeum ovale, n. sp. Ancestrular portion of the type specimen, $\times 15$, incrusting a shell. Lower Miocene (Bowden marl), Bowden, Jamaica.

Figs. 7-9. Gemelliporella punctata, n. sp. (7) Two fragments of the free cylindrical zoarium, natural size; (8) an example, $\times 15$, showing the development of the tremocyst; (9) another fragment, $\times 15$, showing the form of the aperture, ovicells (broken), and arrangement of the areolæ. Lower Miocene (Bowden marl), Bowden, Jamaica.

Fig. 10. Callopora tenella Hincks, 1880. The incrusting zoarium, $\times 15$, illustrating the thin mural rim and the small tubercles on the gymnocyst. Lower Miocene (Bowden marl), Bowden, Jamaica.

Fig. 11. Hemiseptella grandicella, n. sp. Surface of the incrusting zoarium, $\times 15$. The largest zoœcia commence a new row. Lower Miocene (Bowden marl), Bowden, Jamaica.

Fra. 12. Rhamphostomella laticella, $\mathrm{n}$. sp. The incrusting zoarium, $\times 15$. The areolar costules are scarcely visible. Lower Miocene (Bowden marl), Bowden, Jamaica. 


\section{Plate 6.}

Fic. 1. Labiopora miocenica, n. sp. Fragment of the unilamellar zoarium, $\times 15$. The polypidian tube and the small pores of the tremocyst are visible. Lower Miocene (Bowden horizon), Rio Cana, Santo Domingo.

FIG. 2. Hippomenella infratelum, $\mathrm{n}$. sp. Base of a bilamellar zoarium, $\times 15$. The zoccium is regenerated, being replaced by an avicularium. Lower Miocene (Bowden horizon), Cercado de Mao, Santo Domingo.

Fias. 3-5. Schizopodrella mutabilis, n. sp. (3) The tubular zoarium, natural size; (4) zoarium, $\times 15$, with indistinct zoccia; (5) another portion of the same zoarium, $X 15$, showing the shape of the zoccia. Lower Miocene (Bowden horizon), Cercado de Mao, Santo Domingo.

Fiss. 6-9. Steganoporella parvicella, n. sp. (6) Fragments of the unilamellar zoarium, natural size; (7) zoarial fragment, $\times 15$, showing the great irregularity in the zoceia; (8) the usual zoceia, $\times 15$, with regular arrangement; $(9)$ the most frequent aspect of the zoccia, $\times 15$; the polypidian tube is very fragile and often broken or altered. Lower Miocene (Bowden horizon), Cercado de Mao, Santo Domingo.

Fros. 10-15. Thalamoporella biperforata, n. sp. (10) Fragments of the bilamellar zoarium, natural size; (11) specimen, $\times 15$, exhibiting a well-preserved reticulocellarium; (12) an example, $\times 15$, showing the hollow tubules worn and replaced by pores; a reticulocellarium is here present; (13) drawing showing the real form of the aperture, $\times 60$; (14) a specimen, $\times 15$, with a deformed membraniporoid zocecium near the upper corner; (15) another similar example, $\times 15$, with a primoserial membraniporoid zoccium along the lower edge. Lower Miocene (Bowden horizon), Cercado de Mao and Rio Cana, Santo Domingo.

FIGs. 16-19. Stichoporina tuberosa, n. sp. (See also plate 1, figs. 20-23; plate 7, figs. 1-8.) (16) Small fragments of the small free conical zoarium, natural size; (17) zoarial fragment, $\times 15$, with large zoccia; (18) fragment, $\times 15$, with small zoccia; the tubules are well developed; (19) inner side of zoarium, $\times 15$. Lower Miocene (Bowden horizon), Rio Cana, Santo Domingo.

G IGs. 20, 21. Idmonea milneana d'Orbigny, 1839. Views of a fragment, natural size and $\times 9$, referred to this species. Lower Miocene (Bowden horizon), Cercado de Mao, Santo Domingo.

Figs. 22, 23. Adeona porosa, n. sp. Fragment of the free bilamellar zoarium, natural size and $\times 15$. In figure 23 these gonœcia with their oral gibbosities are shown in the upper right-hand corner, an avicularian zocecium in the upper left-hand corner and ordinary zoceia with their ascopores, and small areolæ in the rest of the photograph. Lower Miocene (Bowden horizon), Cercado de Mao, Santo Domingo.

\section{Plate 7.}

Figs. 1-8. Stichoporina tuberosa, n. sp. (See also plate 1, figs. 20-23; plate 7, figs. 16-19.) (1) Group showing the upper, lower, and edge views of the zoarium, natural size; (2) zoarium with weathered surface, $\times 15$, illustrating that the tuberosities are hollow; (3) zoccia, $X 15$, with one preserving the ovicell, which is hyperstomial; (4) portion of a zoarium, $\times 15$, with the tuberosities around the zocecial apertures well preserved; (5) inner surface of zoarium, $\times 7.5$; the tuberosities, avicularia, and hydrostatic (?) cavities are visible; (6) portion of figure $5, \times 15 ;(7)$ edge view of fractured zoarium, $\times 15$, illustrating zoccia open; (8) similar view, $\times 15$, but with the zoceia closed. Lower Miocene (Bowden marl), Bowden, Jamaica.

Fıgs. 9-14. Holoporella albirostris Smitt, 1873, (See also plate 1, fig. 19.) (9) Fragment, $\times 15$, showing zoccia without beak but with the typical form of aperture; (10) zocecia, $\times 15$, showing interzocecial avicularia; the oral beak is incomplete and in process of formation; (11) interior of zoœcia, $\times 15 ;(12)$ general aspect of the zoccia with ovicell, $X 15$; (13) marginal zoccia, $\times 15$; the deep zoccia have a beak bearing a small avicularium which appears then as isolated; (14) zocecia, $\times 15$, showing the different aspects of the beak when broken. Lower Miocene (Bowden marl), Bowden, Jamaica. 


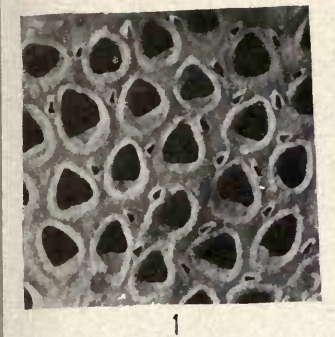

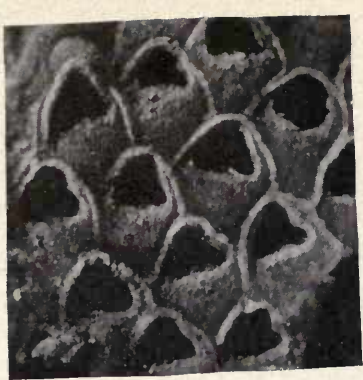

2

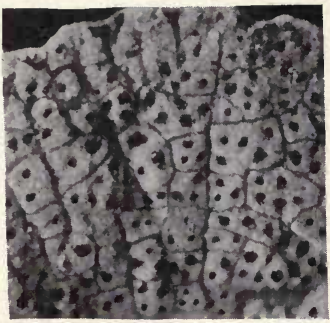

10
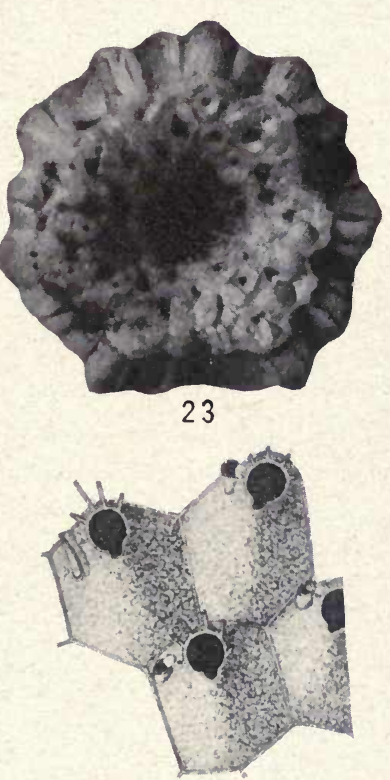

17

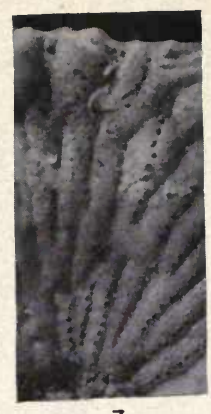

7

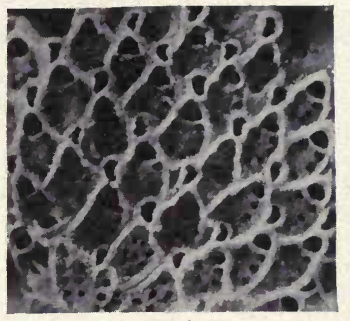

6
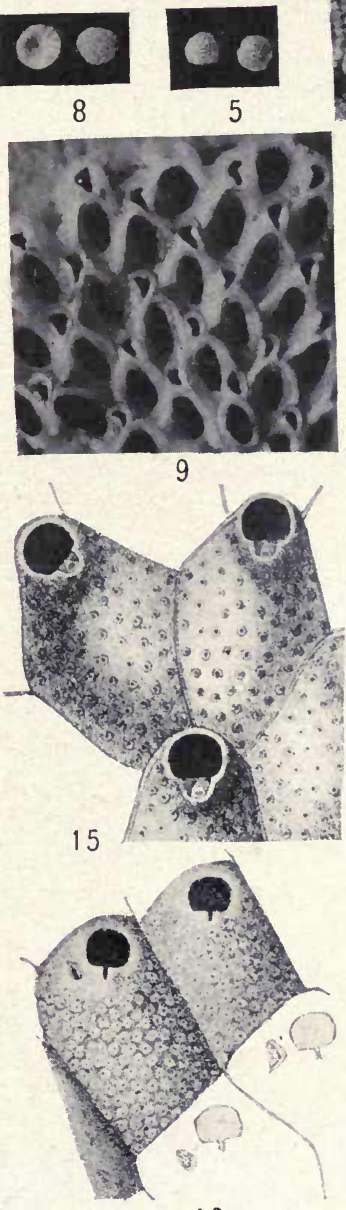

13

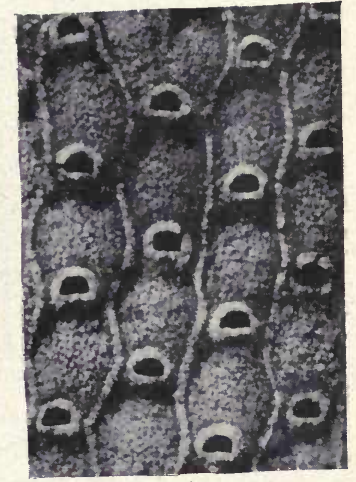

11
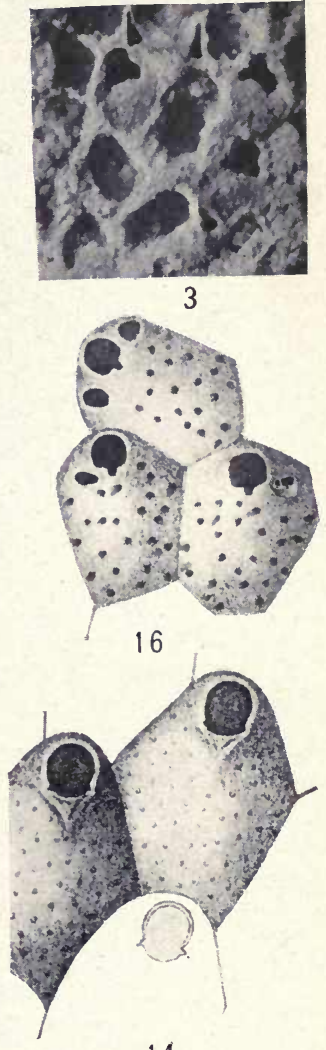

14

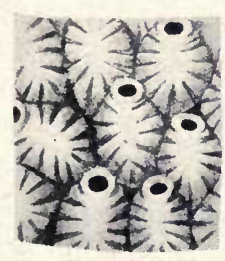

12 

CANU AND BASSLER
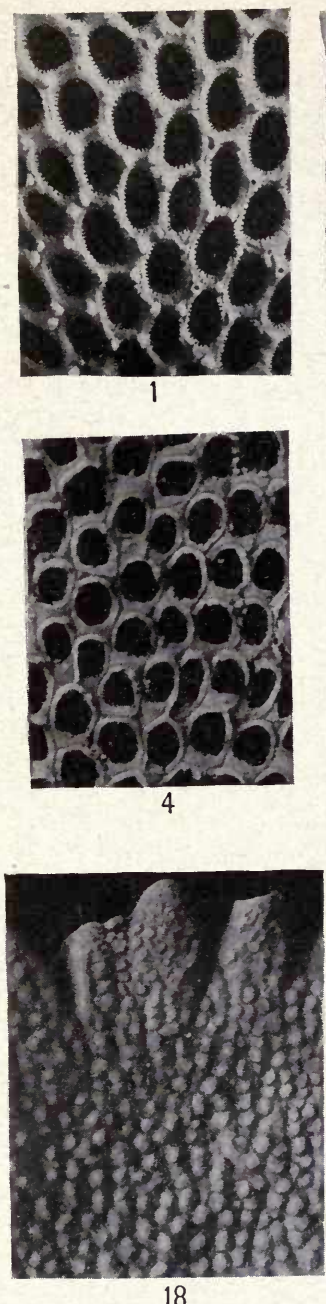

18

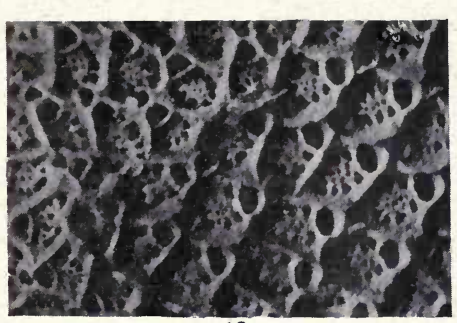

19

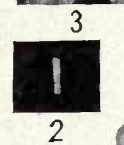

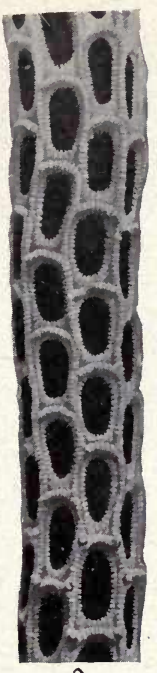
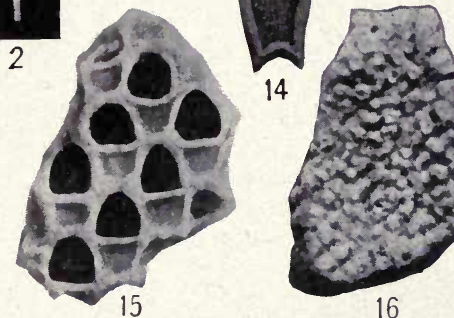

14
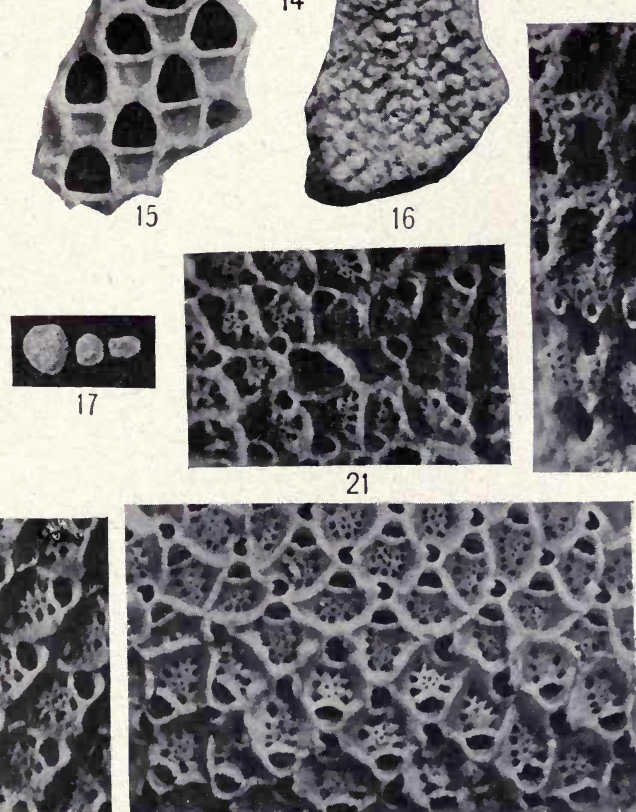

20
PLATE 2

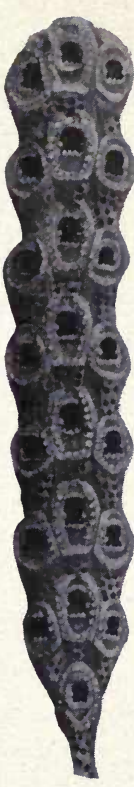

12

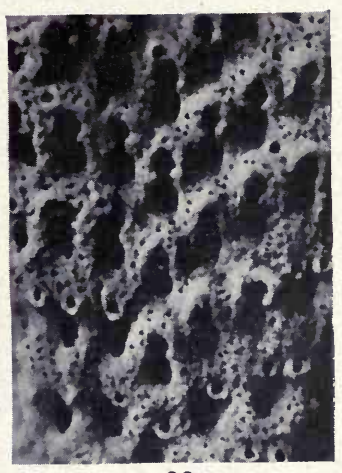

22

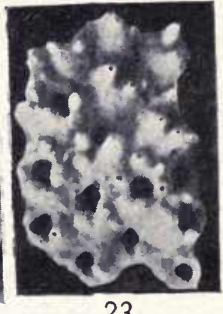

23 



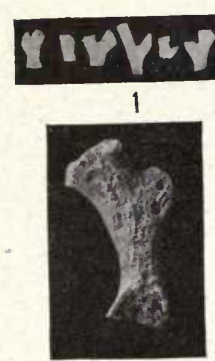

2
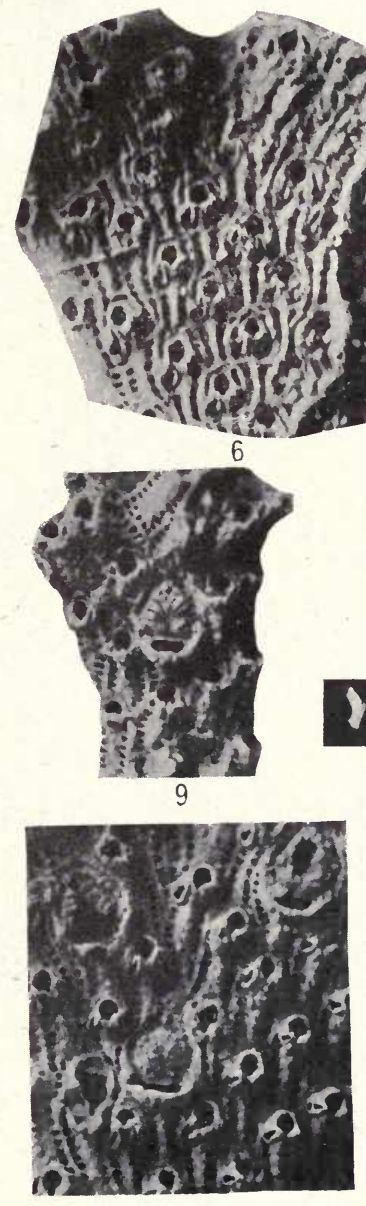

10
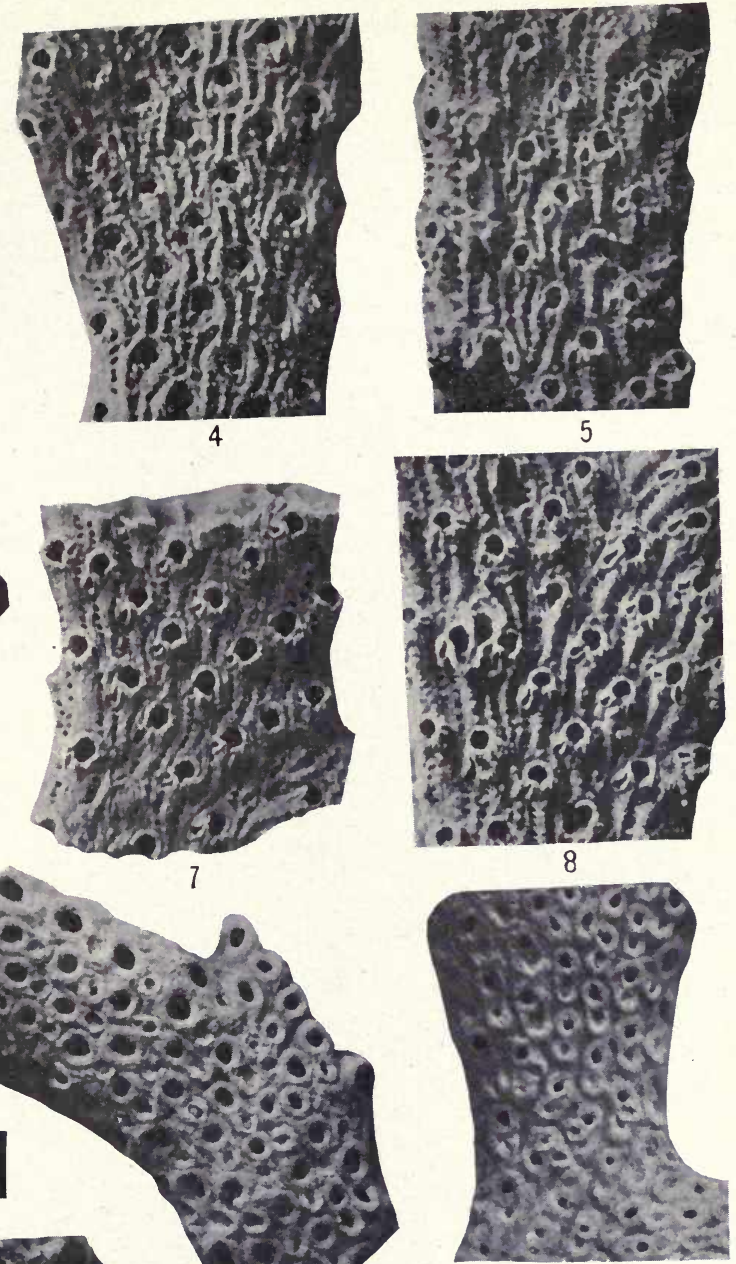

13

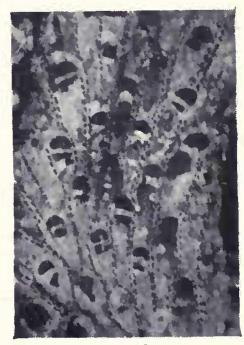

16 


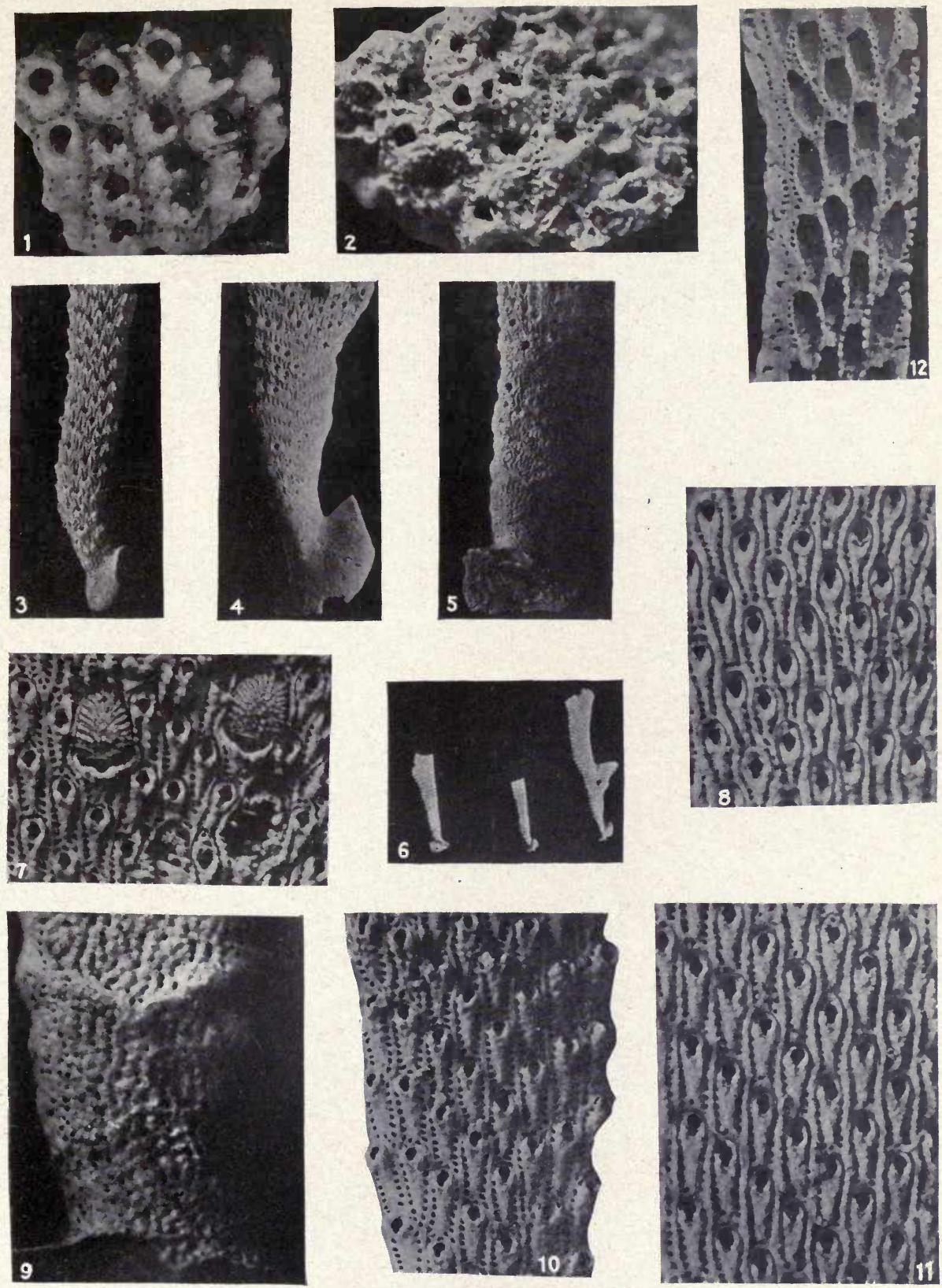


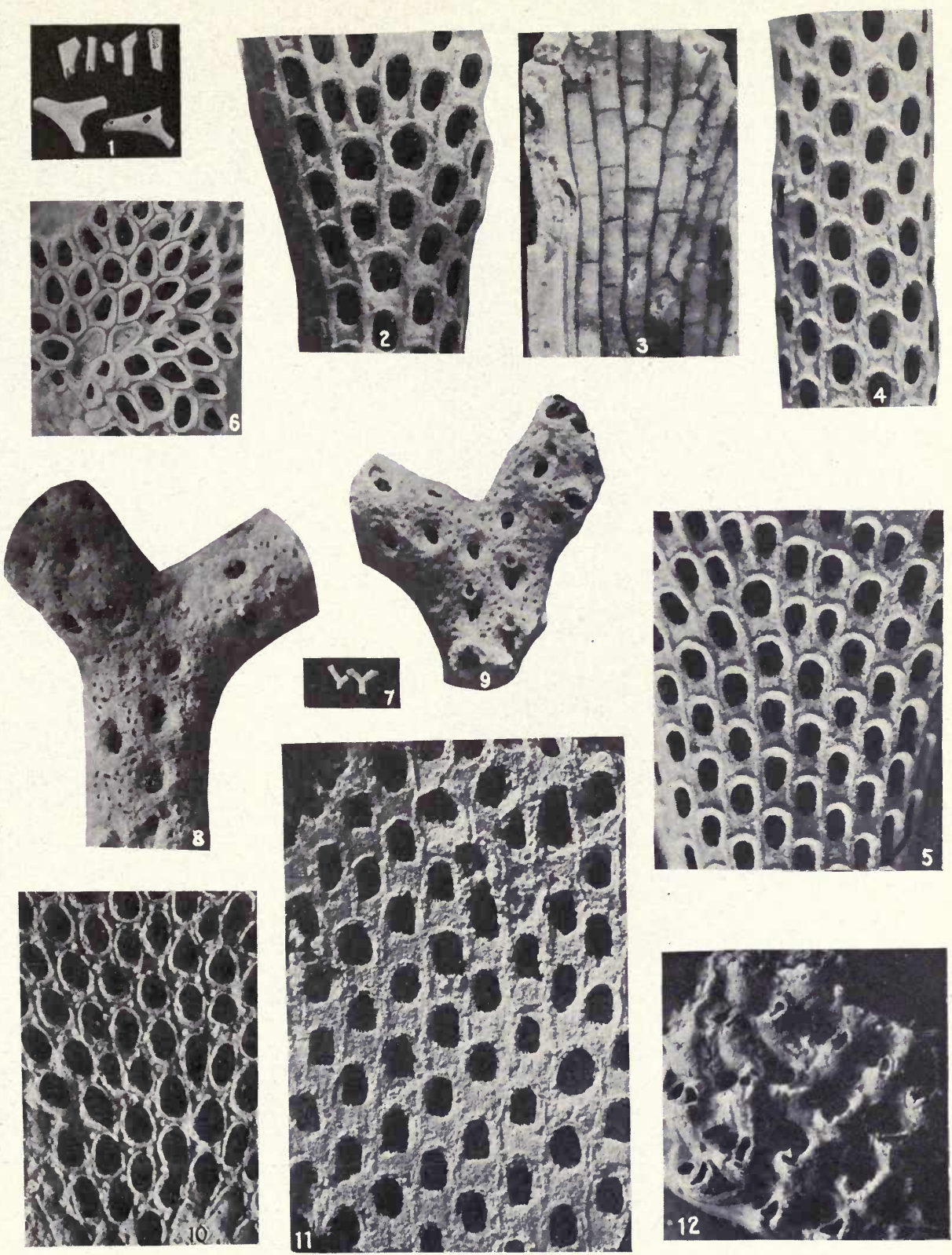

CANU AND BASSLER
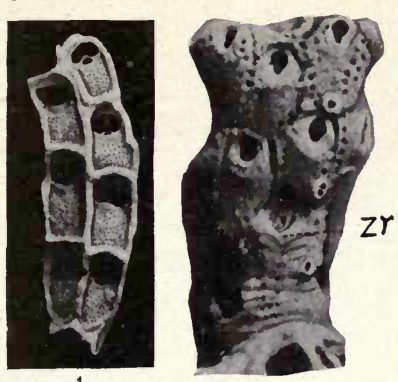

1

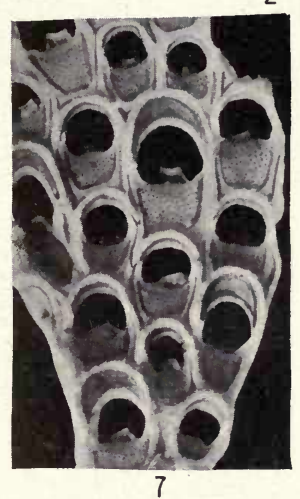

2
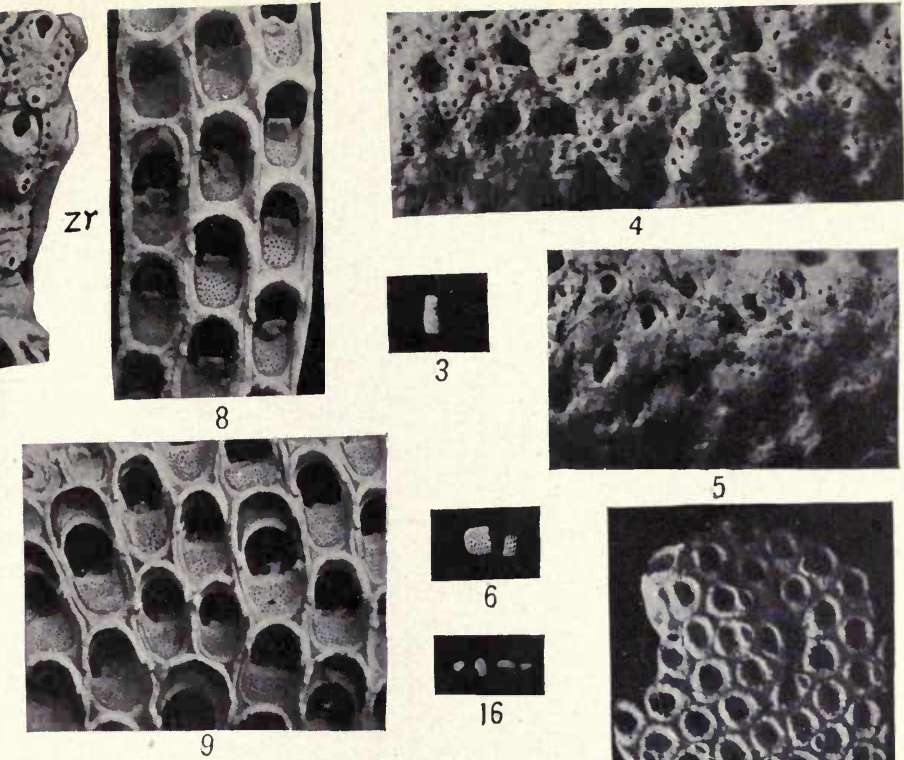

5
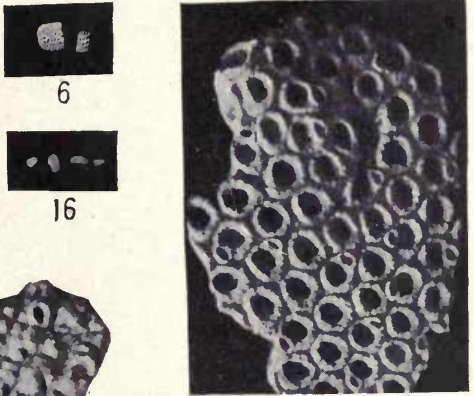

17

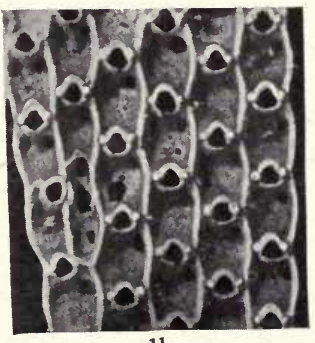

11
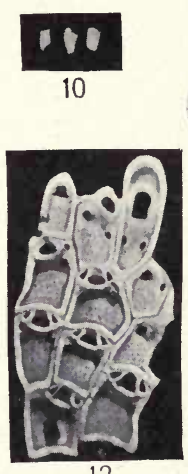

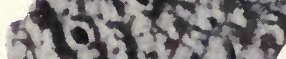
$+.6,5, y)$ 3)

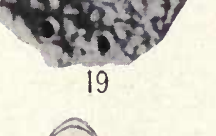

copara - oporitoso ondontara -20360 - asto.

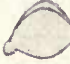

13

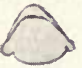

12

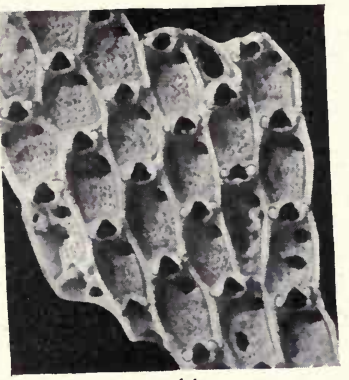

14

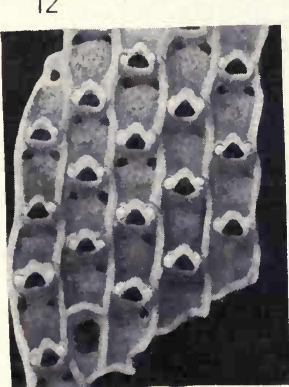

15

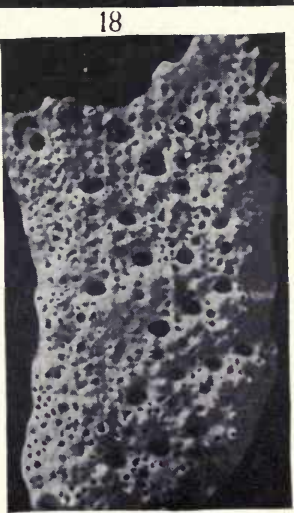

23 

CANU AND BASSLER
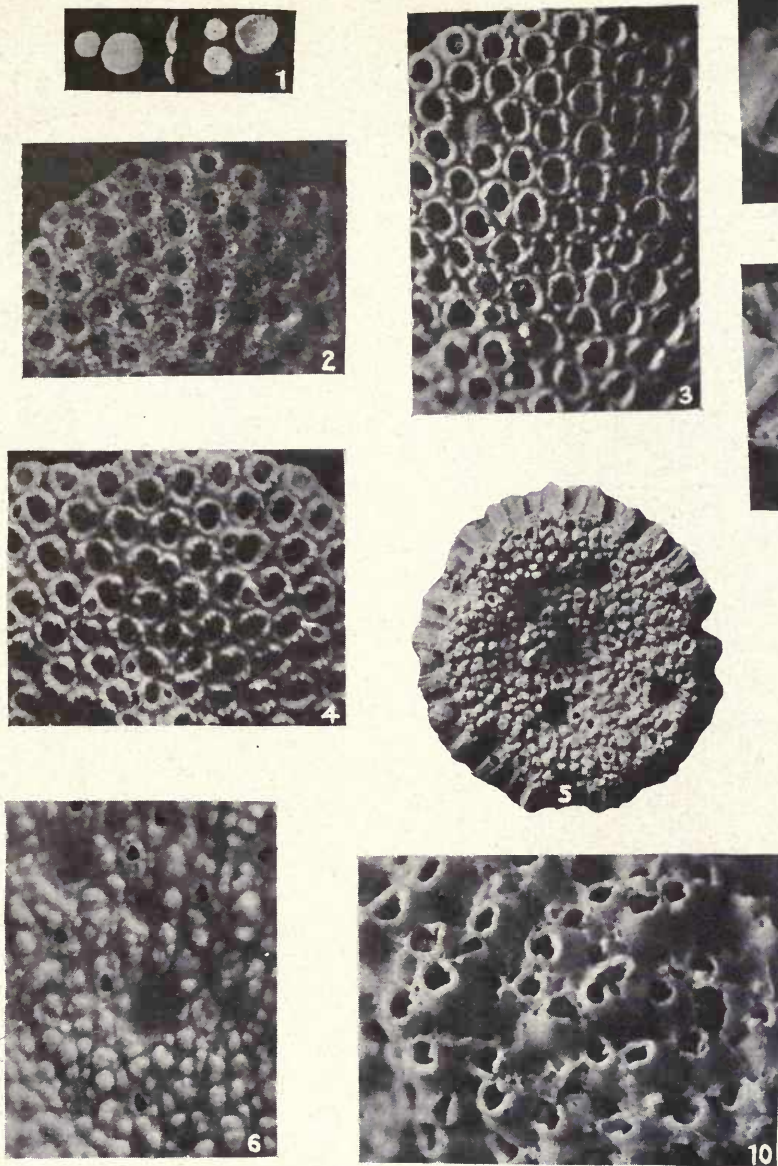

PLATE 7
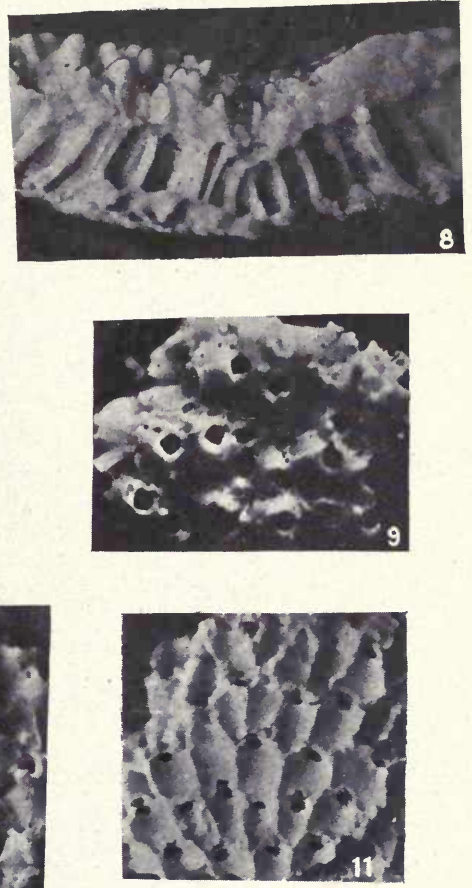
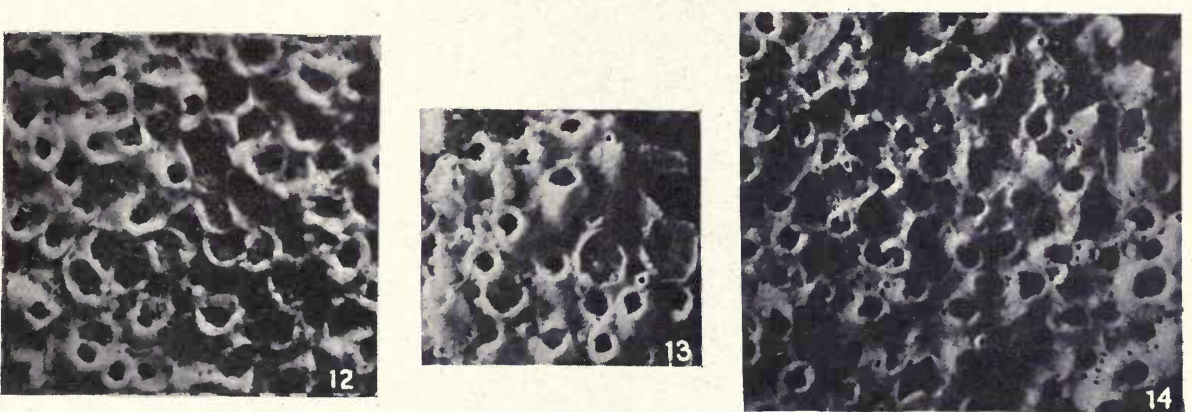

IV.

TERTIARY MOLLUSKS FROM THE LEEWARD ISLANDS AND CUBA.

By Charles Wythe Cooke.

With sixteen plates. 


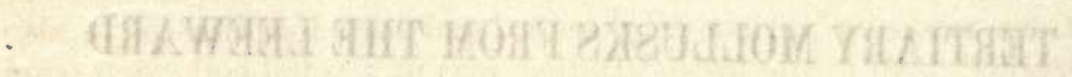

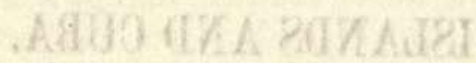

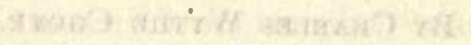

3othlig wasken finge. 


\section{TERTIARY MOLLUSKS FROM THE LEEWARD ISLANDS AND CUBA.}

By Charles Wythe Cooke.

\section{INTRODUCTION.}

The object of this paper is to describe some little-known Cenozoic Mollusca from the West Indies and to determine their stratigraphic positions with respect to the standard section of the Atlantic and Gulf Coastal Plain of North America.

The great bulk of the material upon which this work is based was collected by Dr. T. Wayland Vaughan, in the islands of St. Bartholomew, Antigua, Anguilla, and Cuba, but several additional smaller collections made by various workers at scattered localities have also been studied. All of the fossils studied, except a small collection from Guajay, Cuba, are in the United States National Museum. The exceptions are in the American Museum of Natural History.

The writer wishes to express his appreciation of the many courtesies extended to him throughout the course of the work by Doctor Vaughan, to whom he is also indebted for assistance in the final preparation of the manuscript. He wishes to thank Dr. W. H. Dall and Miss Julia A. Gardner for aid in the identification of doubtful species. He is indebted to the authorities of the United States National Museum for the use of the facilities of that institution and to the Director of the United States Geological Survey for permission to carry on this investigation as part of his official duties.

\section{FAUNAL SUMMARY.}

The species of mollusks and brachiopods described, with the stations at which they were found, are enumerated in the following lists:

\section{List of Stations in St. Bartholomew. T. W. Vaughan, Collector.}

6895. Spur on southeast side of bay northwest of St. Jean Bay, 170 feet above sea-level (aneroid reading).

6897. Anse Écaille side of point between Anse Écaille and Anse Lézard. From conglomerate and sandstone below upper limestone bed.

6897a. Point between Anse Écaille and Anse Lézard.

6897b. Point between Colombier Point and bay next to St. Jean Bay. From a conglomerate and shaly bed interbedded with limestone, below the main limestone and at top of the conglomerate series of beds.

6905. Northwest of St. Jean Bay, along sea-face.

6919. Governors Bay, from limestone picked up on slope.

6924. Point on northwest side of St. Jean Bay, from bed of limestone at top of described section.

6925. Fossils mostly from conglomerate bed below limestone at top of section, partly from lower limestone bed or from just above conglomerate.

6926. Anse Lézard, basal bed. 


\begin{tabular}{|c|c|c|c|c|c|c|c|c|c|c|}
\hline Species. & $\begin{array}{l}12 \\
8 \\
0 \\
0\end{array}$ & 象 & $\begin{array}{l}8 \\
0 \\
8 \\
0 \\
0\end{array}$ & & 녀 & & ฟี & ๙ิ & : & Remarks. \\
\hline 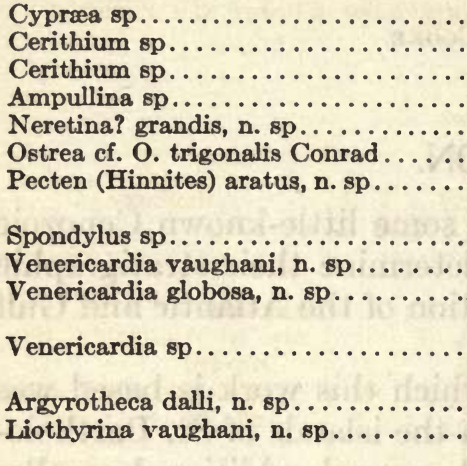 & $\begin{array}{l}\cdots \\
\cdots \\
\cdots \\
\times \\
\cdots \\
\cdots \\
\cdots \\
\cdots \\
\cdots\end{array}$ & 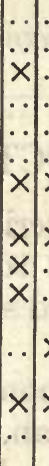 & $\begin{array}{l}\cdots \\
\cdots \\
\cdots \\
\cdots \\
x \\
\times \\
\cdots \\
\times \\
\times \\
\cdots\end{array}$ & $\begin{array}{c}\cdots \\
\cdots \\
x \\
\cdots \\
x \\
\times \\
\ddot{x} \\
\cdots \\
\times \\
\cdots\end{array}$ & $\begin{array}{l}\ddot{x} \\
. \\
\therefore \\
. \\
\dot{x} \\
\therefore \\
\therefore \\
. \\
. \\
.\end{array}$ & $\begin{array}{c}\because \\
\cdots \\
\cdots \\
x \\
\times \\
\cdots \\
\cdots \\
\cdots \\
\cdots \\
\cdots \\
.\end{array}$ & $\begin{array}{l}\cdots \\
. \\
. \\
. \\
x \\
x \\
x \\
\cdots \\
.\end{array}$ & $\begin{array}{c}x \\
x \\
\cdots \\
\dot{x} \\
x \\
\cdots\end{array}$ & $\begin{array}{l}\cdots \\
\cdots \\
.0 \\
x \\
. \\
\cdots \\
\cdots \\
\cdots \\
.\end{array}$ & $\begin{array}{l}\text { Related to Ocala species. } \\
\text { Jackson species. } \\
\text { Hinnites now confined to } \\
\text { Pacific fauna. } \\
\text { Nearest relative is a lower } \\
\text { Eocene species. } \\
\text { Related to the Eocene } V \text {. } \\
\text { planicosta. }\end{array}$ \\
\hline
\end{tabular}

The species from these localities constitute a compact fauna whose closest affinities are in the upper Eocene (Jackson stage).

\section{list of Stations in Antigua. T. W. Vaughan, Collector.}

6854. Rifle butts.

6858. Wetherell Point.

6861. Hodge's Bluff, upper bed.

6862. Hodge's Bluff, lower bed.

6865. Two hundred yards east of Jackass Point, St. Johns Bay.

6866. Across street, north side of cathedral, St. Johns.

6869. Long Island.

6874. Blizzard Mill.

6856. Base and western slope of Friar's Hill.

6875. Friar's Hill, from white chalky limestone above the main coral-reef bed.

6881. From bluffs on north side of Willoughby Bay.

6888. Half a mile north of McKinnon's Mill.

The exposures at all of these localities are of the Antigua formation, except 6861, the upper bed at Hodge's Bluff.

The stratigraphic relations of the different fossiliferous exposures in Antigua can not satisfactorily be determined from the mollusks tabulated below, but according to Dr. Vaughan the corals indicate that all the stations in the table except one (station 6861) represent approximately the same horizon and that this is the equivalent of the coralliferous chert bed at Bainbridge, Georgia. The close relationship of the mollusks to the Tampa and Anguilla faunas is apparent. The single specimen of Epitonium antiguense from the upper bed at Hodge's Bluff (station 6861) probably represents a higher faunal horizon than the other mollusks in the table.

To the small fresh-water fauna described by Brown and Pilsbry ${ }^{1}$ from the tuffs and shales underlying the main Antigua formation, the Vaughan collection adds one new species, Hemisinus atriformis Cooke. The resemblance of this species to a form inhabiting rivers in British

\footnotetext{
${ }^{1}$ Acad. Nat. Sci. Philadelphia Proc., pp. 209-213, plate 9. 1914.
} 
Guiana is in accord with the similarity pointed out by Brown and Pilsbry between $H$. antiguensis and other South American species. The species now known from this fresh-water fauna are the following:

Hemisinus antiguensis Brown and Pilsbry. siliceus Brown and Pilsbry. latus Brown and Pilsbry. atriformis, $\mathrm{n}$. $\mathrm{sp}$.
Bythinella antiguensis Brown and Pilsbry. Planorbis siliceus Brown and Pilsbry.

Species from Antigua.

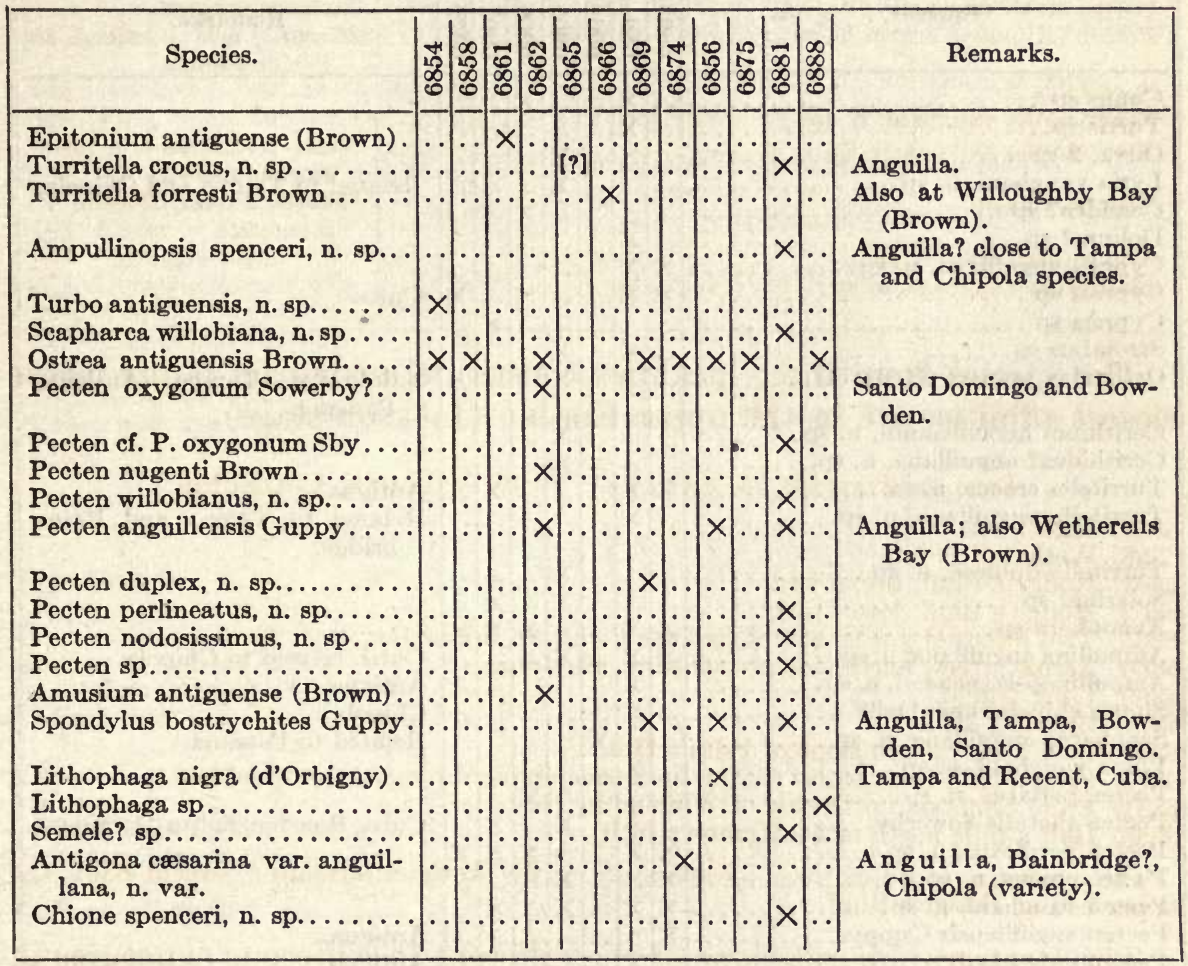

\section{List of Stations in Anguilla. T. W. Vafghan, Collector.}

6893. Crocus Bay, hill, roadside, descent to Crocus Bay from valley.

6894. Crocus Bay, southwest side.

6964. Crocus Bay, southwest side; fossils from rubble above shore-line.

6965. Crocus Bay, southwest shore; fossils from lowest 10 to 15 feet of fossiliferous marls. 6966. Crocus Bay, southwest side, 30 to 50 feet above sea-level.

6967. Crocus Bay, bluff on southwest side, uppermost horizon, 125 feet above sea-level, mainly limestone.

6971. Slope about 100 feet above sea-level, between Little Harbor and Pelican Point.

The mollusks from all the localities in Anguilla, with the possible exception of station 9664 , which is beach rubble, appear to represent a single geologic horizon. The fauna includes species common to formations of ages ranging from the middle Oligocene coral reef at Bainbridge, Georgia, to the Bowden marl of Jamaica, but the number of 
species common to other formations is not great enough to justify using the statistical method of correlation. The fossil horizon of Anguilla is evidently intermediate in age between the Oligocene deposits at Bainbridge and the Bowden marl, and its stratigraphic position is probably not far from that of the Tampa limestone of Florida.

Species from Anguilla.

\begin{tabular}{|c|c|c|c|c|c|c|c|c|}
\hline Species. & $\mid \begin{array}{l}2 \\
0 \\
0 \\
0\end{array}$ & $\begin{array}{l}\not \\
\infty \\
0\end{array}$ & & $\mid \begin{array}{l}12 \\
\$ \\
8\end{array}$ & & : & & Remarks. \\
\hline 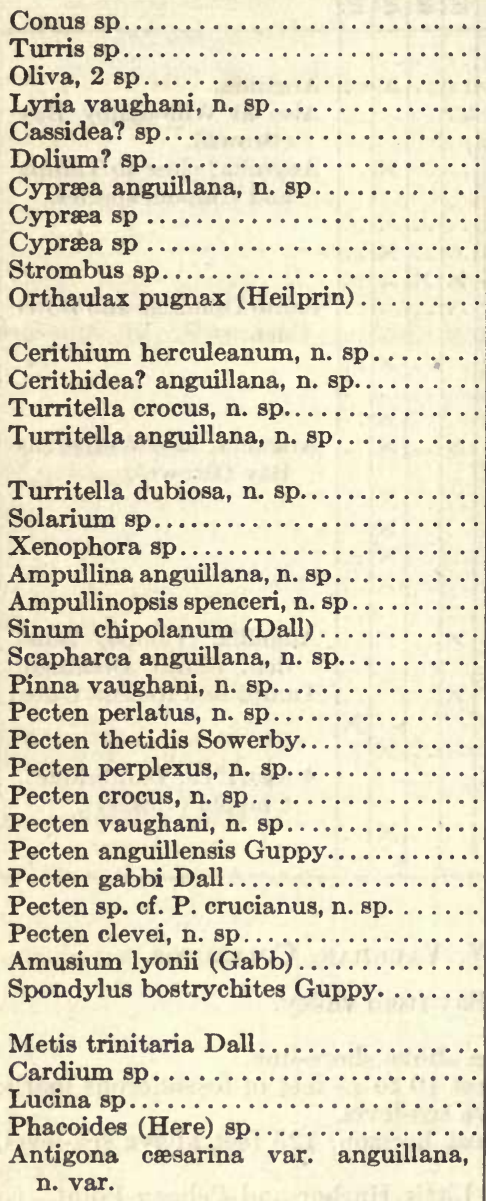 & 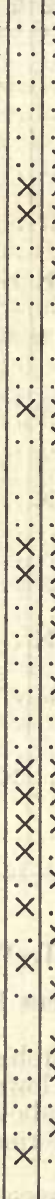 & $\begin{array}{l}x \\
x \\
. \\
\cdots \\
\ddot{x} \\
x \\
x \\
x \\
x\end{array}$ & 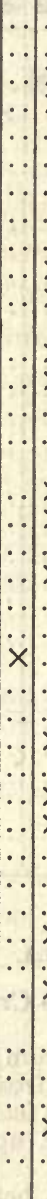 & 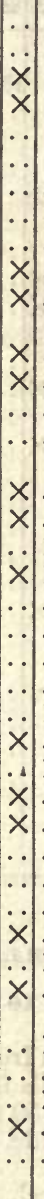 & 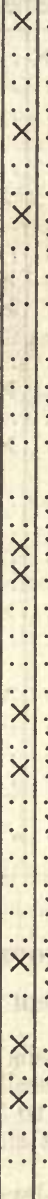 & 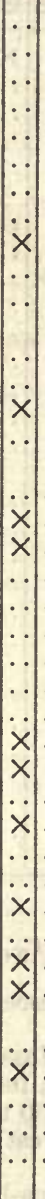 & $\begin{array}{l}. \\
. \\
. \\
. \\
. \\
. \\
. \\
x \\
x \\
. \\
. \\
. \\
. \\
. \\
. \\
. \\
\therefore \\
.\end{array}$ & $\begin{array}{l}\text { Related to Tampa and Chipola. } \\
\text { Cuba. } \\
\text { Bainbridge, Tampa, Antigua, } \\
\text { Panama. } \\
\text { Antigua. } \\
\text { Related to Tampa and Bain- } \\
\text { bridge. }\end{array}$ \\
\hline
\end{tabular}




\section{List of Stations in Cuba.}

3192. One-half mile inland from the pier of the Juragua Railroad on Santiago Bay or Harbor; Joseph Willcox, collector.

3435. Hillside about 2 miles from Santiago, on road to Morro Castle; T. W. Vaughan, collector.

3436. South side of city of Santiago, along trocha in small escarpment separating Terrace 1 from Terrace 2 of coastal shelf, 20-foot level; material brownish yellowish marl with masses of pyrites; T. W. Vaughan, collector.

3439. Juraguá Railroad, La Cruz, below Terrace 3. First cutting on road; T. W. Vaughan, collector.

3440. Northeast portion of Santiago; fossils in marl on hillside; T. W. Vaughan, collector.

3441. East of La Cruz, near railroad crossing of road to Morro Castle; T. W. Vaughan, collector.

3443. Northeast portion of Santiago; marls at foot of hill; T. W. Vaughan, collector.

3446. First deep cutting on railroad east of La Cruz, near Santiago; T. W. Vaughan, collector.

3447. Trocha de Santiago de Cuba, second exposure on north side of trocha east from waterfront, stratum $3 ; \mathrm{T}$. W. Vaughan, collector.

3468. Gorge of Yumuri River below Iglesia Mte. Serrato, Matanzas Province;T. W. Vaughan, collector.

3474. Consolacion del Sur, Pinar del Rio; collected by the Alcalde.

4290. Vento, Province of Habana; Thomas H. Wren, collector.

4291. Calabazar, Province of Habana; Thomas H. Wren, collector.

4292. Near E. C. A., Cuba [within 10 miles of Habana]; Thomas H. Wren, collector.

5255. Santiago de Cuba; Lieutenant Fred. P. Black, collector.

Quarry near asylum near Guajay, 15 miles southwest of Habana; Barnum Brown, collector.

Species from Cuba.

\begin{tabular}{|c|c|c|c|c|c|c|c|c|c|c|c|c|c|c|c|c|c|}
\hline Species. & 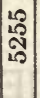 & के & ભి & 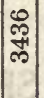 & ঙ্ & & F & $\underset{m}{m}$ & ঙे & mi & 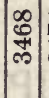 & $\frac{N}{N}$ & 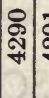 & & & 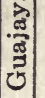 & Remarks. \\
\hline 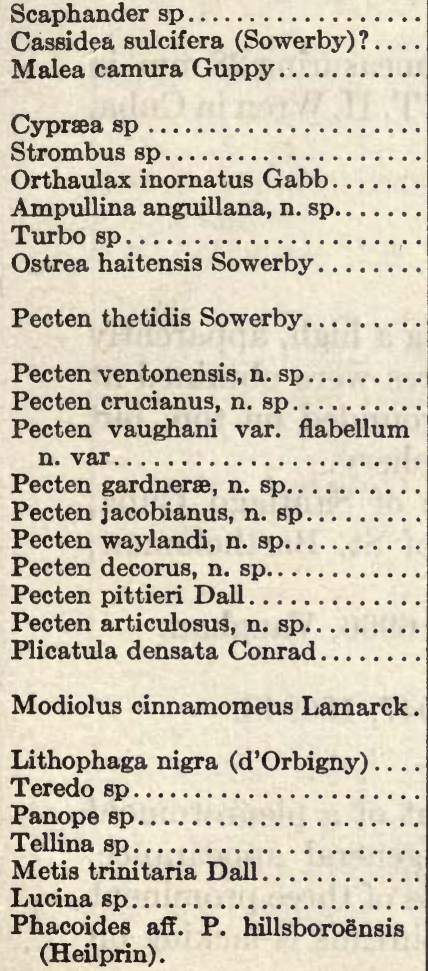 & $\mid \begin{array}{c}\mathrm{x} \\
\cdots \\
\cdots \\
\cdots \\
\mathrm{x} \\
\cdots \\
\cdots\end{array}$ & $\mid \begin{array}{c}x \\
\cdots \\
. \\
. \\
\therefore \\
. \\
\therefore \\
.\end{array}$ & $\begin{array}{c}\because \\
\cdots \\
\cdots \\
\cdots \\
\cdots \\
\cdots \\
\cdots\end{array}$ & $\mid \begin{array}{c}\because \\
\dot{x} \\
\ddot{y} \\
\because \\
\dot{x}\end{array}$ & $\begin{array}{c}\cdots \\
\cdots \\
\ddot{x} \\
\cdots \\
\cdots\end{array}$ & $\begin{array}{c}x \\
x \\
x \\
x \\
x \\
\cdots \\
\cdots \\
\cdots\end{array}$ & $\begin{array}{l}\ddot{x} \\
x \\
\cdots \\
\cdots \\
\cdots \\
\cdots \\
\cdots \\
\cdots\end{array}$ & $\begin{array}{c}\because \\
x \\
\cdots \\
\cdots \\
\cdots \\
\cdots\end{array}$ & $\begin{array}{r}\because \\
\therefore \\
\therefore \\
\therefore \\
\therefore \\
\therefore\end{array}$ & $\begin{array}{c}\cdots \\
\cdots \\
\cdots \\
\cdots \\
\cdots \\
\cdots \\
\cdots\end{array}$ & $\cdot \begin{array}{c}\cdots \\
\cdots \\
\cdots \\
\cdots \\
\cdots \\
\cdots \\
\cdots \\
.\end{array}$ & 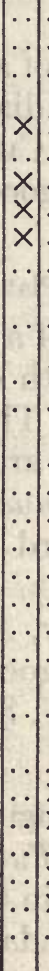 & $\begin{array}{c}\because \\
\cdots \\
\because \\
\cdots \\
\cdots \\
\cdots \\
\cdots\end{array}$ & $\begin{array}{c}x \\
\cdots \\
\cdots \\
\cdots \\
\cdots\end{array}$ & $\begin{array}{l}\cdots \\
\cdots \\
\cdots \\
\cdots \\
\cdots \\
\cdots \\
\cdots \\
\cdots \\
\cdots \\
\cdots\end{array}$ & $\begin{array}{c}\cdots \\
\cdots \\
\cdots \\
\cdots \\
\ddot{x} \\
\ddot{x} \\
\cdots\end{array}$ & $\begin{array}{l}\text { Bainbridge, Santo Domingo. } \\
\text { Bowden, Santo Domingo, } \\
\text { Gatun. } \\
\text { Anguilla. } \\
\text { Tampa, Santo Domingo. } \\
\text { Anguilla, aff. Chipola. } \\
\text { Haiti, Bowden, Chipola, } \\
\text { Oak Grove. } \\
\text { Anguilla, Bowden, Santo Do- } \\
\text { mingo. } \\
\text { Related to Anguilla. } \\
\text { Costa Rica. } \\
\text { Tampa, Chipola, Oak Grove, } \\
\text { Miocene of New Jersey. } \\
\text { Tampa Chipola, Trinidad, } \\
\text { Recent. } \\
\text { Tampa to Recent. } \\
\text { Santo Domingo. } \\
\text { Like Recent species. } \\
\text { Trinidad. } \\
\text { Aff. Tampa and Chipola. }\end{array}$ \\
\hline
\end{tabular}


The greater number of collections from Cuba appear to have come from a single geologic horizon which is exposed at numerous localities in the vicinity of Santiago. The fauna, which is characterized by a profusion of pectens, bears a close resemblance to those of Tampa and Anguilla, but may be a little younger. The fossils from Consolacion del Sur (station 3474), among which is Orthaulax inornatus, have not been found elsewhere in Cuba, but tie up with the Tampa and Anguilla faunas. The small collections from Calabazar (station 4291) and Guajay probably are of nearly the same age. The fossils from Havana (station 4292) may be somewhat younger than the others, but the evidence is inconclusive.

Interesting collections were obtained by Wiebusch (stations 3652 , 5312) from the asphalt beds at the Angela Elmira mine near Bejucal. These include both fresh-water and marine species which may have been derived from beds of different ages. The fossils are referred doubtfully to the Oligocene. The list follows:

Fossils from the Asphalt Beds near Bejucal.

Levifusus? angelicus, n. sp.

Cypræa semen, n. sp.

Hemisinus bituminifer, $\mathrm{n}$. sp.

Hemisinus costatus, n. sp.

Elmira cornu-arietis, n. gen. et sp.
Unio bitumen, $\mathrm{n}$. sp.

Margarita naticoides, n. sp.

Solemya sulcifera, $\mathrm{n}$. sp.

Myrtæa? asphaltica, n. sp.

\section{DESCRIPTIONS OF SPECIES.}

\section{Scaphander species.}

A well-preserved cast of a species of Scaphander measuring $28 \mathrm{~mm}$. in altitude and $16.4 \mathrm{~mm}$. in diameter was collected by T. H. Wren in Cuba.

Locality.-Calabazar, Cuba, station 4291.

Geologic horizon.-Oligocene.

\section{Conus species.}

(Plate 1, Figures $5 a, b, 6 a, b$.)

Casts of the interior of a species of Conus having a high, apparently bulbous nucleus and with deeply channeled sutures were obtained at Crocus Bay, Anguilla. The smaller whorls are rounded on top, but the more mature whorls are angulated at the periphery.

Another species of Conus occurs in the Miocene of Santiago, Cuba, station 5255, and a third in the upper Eocene of St. Bartholomew, station $6897 a$.

Locality.-Crocus Bay, Anguilla, stations 6894, 6966, Vaughan.

Geologic horizon.-Oligocene.

Figured specimens.-U. S. Nat. Mus., Nos. 166947, 166948.

\section{Turris species.}

From Crocus Bay, Anguilla, there is a fragment of a pleurotomoid shell which resembles Turris albida (Perry) in general appearance. The major sculpture, as in the species cited, consists of three prominent spiral threads; the secondary sculpture of spiral threads is lacking on 
our specimen; the growth lines, unlike those of $T$. albida, are not prominent; the notch coincides in position with the middle thread.

It may not be out of place to remark here that Pleurotoma cochlearis Conrad, from Vicksburg, Mississippi, which has been placed in the synonymy of Turris albida by several writers, is clearly distinct from that species and probably belongs to a different section. Although the sculpture of the mature whorls is so similar that decollated specimens can scarcely be distinguished from $T$. albida, the protoconchs of the two are unlike.

Locality.-Crocus Bay, Anguilla, station 6894, Vaughan.

Geologic horizon.--Oligocene.

Oliva species.

(Plate 1, Figure 1.)

In the lower bed at Crocus Bay, Anguilla, occur two species of Oliva, one of which is figured. It is a plump, low-spired shell with a thick aperture. The other is higher spired and proportionately more slender.

Locality.-Crocus Bay, Anguilla, station 6965, Vaughan.

Geologic horizon.-Oligocene.

Figured specimen.-U. S. Nat. Mus., No. 166953.

\section{Lyria vaughani, new species.}

(Plate 1, Figure 4.)

The following is a description of this species:

Shell volutiform, spire high; nucleus small, succeeded by 5 whorls with high narrow axial costæ, about 9 on the body whorl, near the anterior extremity of which are several oblique threads; aperture wide, about two-thirds the length of the shell; pillar lip with 3 basal folds and apparently several indistinct folds and an elliptical node at the posterior end; anterior canal short, with an oblique fasciole.

Alt. 22; diam. 12.5; alt. of body whorl $15 \mathrm{~mm}$.

This species resembles Lyria musicina Heilprin, but is smaller, has a smaller nucleus, sharper and closer ribs, fewer columellar folds, and more prominent basal fasciole.

Locality.-Crocus Bay, Anguilla, station 6965, Vaughan.

Geologic horizon.-Oligocene.

Type.-U. S. Nat. Mus., No. 166955.

\section{Levifusus? angelicus, new species.}

(Plate 1, Figures 2, $3 a, b$.)

The following is a description of this species:

Shell thin, rapidly expanding; spire low; whorls about $4 \frac{1}{2}$, shouldered, with narrow axial costæ, about 16 to the whorl, extending from suture to suture on the spiral whorls but obsolete on the body whorl or reduced to low nodes on the carina; shoulder with many faint, simple, revolving threads and, near the suture, one stronger thread forming nodes at the intersections with the axial ribs; periphery of whorls nearly cylindrical, set with 5 or more strong, 
raised threads which increase in number and decrease in relative size on the body whorl; base of whorl to end of canal covered with flat threads; canal short, straight; inner lip smooth, with a thin deposit of callus; outer lip thin, broken, with no traces of internal liræ, but inner surface of shell very minutely, closely, spirally lined; aperture broad, semilunate.

Alt. of smaller fragment, spire lacking, $12.5 \mathrm{~mm}$.; diam. of body whorl, $9.5 \mathrm{~mm}$; alt. of larger specimen, end of canal lacking, $17.4 \mathrm{~mm}$.; diam. of body whorl, $13.5 \mathrm{~mm}$.

The larger of the two specimens of this species has lost nearly all of the superficial layers of shell from the whorls of the spire, which have thus acquired an unnatural rotundity. The tip of the spire of the smaller shell is broken, but the lower whor's show the shape and sculpture very well.

Owing to the absence of the protoconch and nepionic whorls, it is impossible to determine with certainty the precise generic relationships of this shell. It appears rather close to Levifusus, to which I have provisionally referred it, but is less acutely carinate and tuberculate than the type of that genus and appears to have a broader aperture and a shorter canal.

Locality.-Angela Elmira asphalt mine, near Bejucal, Cuba, station 3652, Wiebusch.

Geologic horizon.-Oligocene? asphalt beds.

Type.-U. S. Nat. Mus., No. 166957.

Epitonium (Sthenorhytis) antiguense (Brown).

(Plate 1, Figure 8.)

Scala (Sthenorhytis) antiguensis Brown, Proc. Acad. Nat. Sci. Phila., p. 612, plate 20, fig. 9 , 1913.

The following is the original description of this species:

"Shell turbinate, of about five whorls, rapidly enlarging; the suture impressed, whorls rounded, crossed by about sixteen varices which are acute edged and rise abruptly from the whorl. The intervarical spaces are crossed by five raised revolving cords with a secondary sculpture of fine, somewhat irregularly spaced revolving lines and crossed by radial lines parallel to the varices. This secondary sculpture which covers the varices also, is best observed with a lens. From the excavated form of the base of the shell, it is probable that the mouth was circular, but this portion of the shell is imperfect. Alt. $30 \mathrm{~mm}$., diam. $19 \mathrm{~mm}$. From the Hodge's Hill limestone (Antigua formation), Hodge's Bay, Antigua. Oligocene."

This species probably has more than 5 whorls, but from the single specimen at hand, a crushed fragment of 3 whorls, it is impossible to determine the number. The varices are curved gently away from the mouth.

Locality. - Upper bed at Hodge's Hill, station 6861, Vaughan.

Geological horizon.-Oligocene?

Type.-Philadelphia Academy, No. 1645.

Figured specimen.-U. S. Nat. Mus., No. 166958. 


\section{Cassidea sulcifera (Sowerby)?}

Cassis sulcifera Sowerby, Quart. Jour. Geol. Soc. London, vol. 6, p. 47, plate 10, fig. 1, 1850. (Date of imprint 1849.)

Cassis sulcifera Dall, Proc. U. S. Nat. Mus., vol. 51, p. 508, plate 86, fig. 4, 1916.

Cassis sulcifera Maury, Bull. Amer. Pal., vol. 5, p. 275, plate 44, figs. 1-3, 1917.

The following is the original description of this species:

"Testa ovato-trigona, crassiuscula, anfractibus senis, longitudinaliter sulcatis, ultimo seriebus duabus ad tribus tuberculorum ornato, serie postica eminentiore; apertura lata; margine interno labii externi dentato, dentibus paucis distantibus; labio interno transverse costellifero; costellis anticis prominentioribus."

The Cuban specimens, which are doubtfully referred to this Dominican species, are preserved as casts only. They attained a size considerably larger than was customary for $C$. sulcifera, but resemble it in shape and general appearance, and are unlike any other described species from this region with which I am acquainted. The largest specimen at hand measures $9 \mathrm{~cm}$. in length and $7.5 \mathrm{~cm}$. in maximum width.

Locality.-Calabazar, Province of Habana, Cuba, station 4291, Wren. Sowerby's type was collected by Heneken in Santo Domingo and the species has recently been obtained by Vaughan, Mansfield, and Cooke from the base of the Chattahoochee formation at Red Bluff, near Bainbridge, Georgia.

Geologic horizon.-Oligocene.

Type.-British Museum.

\section{Cassidea? species.}

Indeterminable casts of a medium-sized species with a high spire were found at Crocus Bay, Anguilla. They attained an altitude of about $5 \mathrm{~cm}$.

Locality.-Crocus Bay, Anguilla, station 6966, Vaughan.

Geologic horizon.-Oligocene.

\section{Dolium species.}

An internal cast which resembles Malea camura, but appears to be a little more cylindrical than that species. The impression of the inner lip is obliterated, so that the specific characteristics can not be made out.

Alt., $36 \mathrm{~mm}$; diam., $26 \mathrm{~mm}$.

Locality.-Crocus Bay, Anguilla, station 6894, Vaughan.

Geologic horizon.-Oligocene.

Malea camura Guppy.

Malea ringens Conrad, Pacific R. R. Repts., vol. 6, p. 72, plate 5, fig. 22, 1857.

Malea camura Guppy, Quart. Jour. Geol. Soc. London, vol. 22, p. 287, plate 17, fig. 9, 1866.

Malea camura Brown and Pilsbry, Proc. Acad. Nat. Sci. Phila., p. 356, 1911.

Malea camura Maury, Bull. Amer. Pal., vol. 5, p. 276, pl. 45, fig. 3, 1917. 
The following is Guppy's description of this species:

"Shell ovate, ventricose; whorls 6-7, destitute of varices, zoned by about 16 low spiral ridges; spire short, conic; aperture rather narrow, outer lip thickened, dentate; inner lip sinuate, dentate; columella tortuous, irregularly folded or plaited; callus thin."

This species is very closely related to Malea ringens Swainson, living in the Pacific Ocean, with which it was confused by Conrad. It appears to have attained adult characters at a somewhat smaller size and to have more delicate sculpture than the recent species, but in other respects to be almost indistinguishable from it. It is interesting to find this type of shell surviving with such slight modifications in the Pacific Ocean, but now quite extinct in the Antillean region, where it was once so widely distributed.

Malea camura is represented in the Cuban collections by only one cast of the interior, but there can be little doubt of the correctness of the identification.

Localities. - Near Havana, Cuba, station 4292, Wrenn, collector; also Bowden, Jamaica; Haiti; Pontou, Santo Domingo;and Gatun, Panama.

Geologic horizon.-Oligocene.

Types.-U. S. Nat. Mus., Nos. 115506 and 115507.

\section{Cypræa anguillana, new species.}

(Plate 1, Figures $9 a, b$.)

The following is a description of this species:

Shell subellipsoidal, smooth, polished; spire mammiform, with sutures obliterated; aperture narrow; outer lip closely dentate with about 20 tubercles; inner lip obsoletely dentate well within the aperture; inner and outer lips pinched or flattened at the anterior end.

Alt., $25 \mathrm{~mm}$; diam., $14.5 \mathrm{~mm}$.

Locality.-Crocus Bay, Anguilla, station 6894; the cast of a larger specimen, probably C. anguillana, was found at station 6893, Vaughan.

Geologic horizon.-Oligocene.

Type.-U. S. Nat. Mus., No. 166963.

\section{Cypræa semen, new species.}

(Plate 1, Figures $10 a, b$.)

The following is a description of this species:

Shell small, rotund; surface smooth and polished, but inner layers of shell exhibiting faint, distantly spaced lirations transverse to the axis; outer lip with 22 or 23 evenly spaced denticulations placed well within the aperture; inner lip with 5 denticulations on the anterior half and several obsolescent denticulations on the posterior half; canals short, nearly equal.

Length, $8.5 \mathrm{~mm}$.; diameter, $5.8 \mathrm{~mm}$.

Locality.-Angela Elmira asphalt mine near Bejucal, Cuba, station 3652; Wiebusch, collector.

Geologic horizon.-Oligocene?

Type.-U. S. Nat. Mus., No. 166965. 
Cypræa species.

Besides Cyproea anguillana, two species of Cyproza occur at Crocus Bay, Anguilla. One is represented in the collection by a single crushed specimen with an ornamentation of raised spiral lines resembling the sculpture of Ovula multicarinata Dall. It was found at station 6967. The other, a large globose form preserved only as casts, is abundant and occurs also in Cuba.

Localities.-Crocus Bay, Anguilla, stations 6893, 6894, 6966, 6971, Vaughan; Consolacion del Sur, Vento, and Calabazar, Cuba, stations $3474,4290,4291$, Wren.

Geologic horizon.-Oligocene.

Cypræa, indeterminate species.

One indeterminable cast.

Locality.-Northwest side of St. Jean Bay, St. Bartholomew, station 6925 , Vaughan.

Geologic horizon.-Upper Eocene.

Strombus species.

(Plate 2, Figures $5 a, b$.)

Casts of a huge species of Strombus with a moderately high spire have been found at Crocus Bay, Anguilla. The largest specimen exceeded $20 \mathrm{~cm}$. in altitude and $15 \mathrm{~cm}$. in diameter. Smaller specimens about $8 \mathrm{~cm}$. in altitude, have a very low spire and long tubercles and probably represent a different species. The figured specimen, measuring $38 \mathrm{~mm}$. in altitude, probably belongs to a third species.

A Strombus occurs in the Oligocene of Santiago, Cuba, station 5255.

Locality.-Crocus Bay, Anguilla, stations 6894, 6965, Vaughan.

Geologic horizon.-Oligocene.

Figured specimen.-U. S. Nat. Mus. No. 166983.

\section{Orthaulax pugnax (Heilprin).}

(Plate 2, Figures 3, 4.)

Wagneria pugnax Heilprin, Trans. Wagner Inst., vol. I, p. 106, plate 15, figs. 36, 36a, 1887.

Orthaulax pugnax Dall, Trans. Wagner Inst., vol. III, p. 170, plate 8, figs. 5, 8, 1890.

Orthaulax pugnax Dall, U. S. Nat. Mus. Bull. 90, p. 87, plate 15, figs. 5, 10, 1915.

Orthaulax pugnax Dall, Proc. U. S. Nat. Mus., vol. 51, p. 509, 1916.

The following is the original description of this species.

"Shell irregularly oval, obconical, flattened, the flattened appearance being due to three irregular swellings or knobs, one of which immediately adjoins the anteriorly-directed fissure of the aperture; aperture narrow, projected forward (in its upper course) as a closely compressed fissure, which in a crescential curve ascends to within a comparatively short distance of the apex of the spire; outer lip? (broken in specimen); inner lip largely developed, completely concealing the whorls of the spire, and duplicating for a very considerable extent the outer lip; spire freely enclosed in a pointed superstructure, or dome, built over it by an extension of the mantle; surface covered with longitudinal lines of growth, which extend continuously from the apex to the base.

"Length (of imperfect specimens, lacking probably upward of an inch), 2.7 inches; width, 1.75 inches." 
Localities.-Antigua, Spencer; Crocus Bay, Anguilla (sta. 6965), Vaughan. Occurs also at Bainbridge, Tampa, and Canal Zone (sta. 5901, 2 miles south of Mitchellville, P. R. R.).

Geologic horizon.-Oligocene.

Type.-Wagner Institute, Philadelphia.

Figured specimens.-U. S. Nat. Mus. Nos. 166982, 166984.

\section{Orthaulax inornatus $\mathrm{Gabb}$.}

(Plate 2, Figures 1, 2.)

Orthaulax inornatus Gabb, Proc. Acad. Nat. Sci. Phila., vol. 24, p. 272, plate IX, figs. 3, 4, 1872.

Orthaulax inornatus Gabb, Trans. Amer. Phil. Soc., n. 8., Vol. XV, p. 234, 1873.

Orthaulax inornatus Guppy, Quart. Jour. Geol. Soc. London, vol. 32, p. 520, plate 28, fig. 8, 1876.

Orthaulax inornatus Dall, U. S. Nat. Mus. Bull. 90, p. 86, plate 11, fig. 4, 1915.

Orthaulax inornatus Dall, Proc. U. S. Nat. Mus., vol. 51, p. 509, plate 88, fig. 9, 1916.

Orthaulax inornatus Maury, Bull. Amer. Pal., vol. 5, p. 285, plate 47, fig. 11, 1917.

The following is Gabb's description of this species (1873):

"Shell broadly rounded-fusiform. Young shell with the spire a little shorter than the aperture, suture impressed, whorls numerous, nuclear whorls three, the subsequent ones showing faint traces of occasional thickenings disposed like the varices of Triton; surface smooth; anterior end of body whorl marked by a few faint revolving lines, no posterior canal. Adult shell more distinctly fusiform, the spire covered with a longitudinally striated incrustation covering the sutures and extending to the extreme apex. Aperture elongated, acute behind and prolonged into a very narrow posterior canal running straight to the apex; in advance it is gradually narrowed, the anterior notch broad and shallow; inner lip thinly encrusted; outer lip thin in all my specimens, and apparently thin, straight and entire in the perfect adult. Size of largest specimen, length 3.75 inches, width 1.5 inches."

Two broken specimens, much larger than any previously figured, were obtained in Cuba. As one would expect of shells of this type, the apical angle of the adult shell is much more obtuse than that of the immature specimen. The faint revolving lines on the anterior end extend posteriorly to the position of maximum diameter of the whorl. In other respects, the Cuban fossils resemble those from Santo Domingo and Florida.

Localities.-Consolacion del Sur, Pinar del Rio, Cuba, station 3474, the Alcalde, coll.; Santo Domingo; Tampa; Bainbridge.

Geologic horizon.-Oligocene.

Type.-Philadelphia Academy.

Figured specimens.-U. S. Nat. Mus. No. 166980.

\section{Cerithium herculeanum, new species.}

(Plate 1, Figure 7.)

The following is a description of this species:

Shell large, broad at the base; decollated, 10 subsequent whorls; spiral sculpture from anterior to posterior as follows: 1 inconspicuous thread adjacent to the suture; 1 row of nodes becoming acuminate on the larger whorls; 2 low, 
simple threads; 1 row of high, pointed nodes convex anteriorly, concave posteriorly, forming a coronation adjacent to the suture. Outer lip and canal broken.

Length of fragment of 10 whorls, apex and part of anterior canal missing, $85 \mathrm{~mm}$.; diam. at decollation $7 \mathrm{~mm}$.; diam. of body whorl, $37 \mathrm{~mm}$.

This species is readily distinguishable from others of the midAmerican region by its large size and peculiar sculpture.

Locality.-Crocus Bay, Anguilla, station 6965, Vaughan.

Geologic horizon.-Oligocene.

Type.-U. S. Nat. Mus. No. 166985.

\section{Cerithium species.}

Casts of a large Cerithium were obtained by Vaughan on the northwest side of St. Jean Bay, St. Bartholomew, at stations 6905 and 6925. A smaller species retaining the silicified shell, which shows imperfectly the original sculpture, was collected at station 6897 , a point between Anse Êcaille and Anse Lézard.

Geologic horizon.-Upper Eocene.

\section{Cerithidea? anguillana, new species.}

(Plate 3, Figures $10 a, b, 11,12 a, b$.)

The following is a description of this species:

Shell slender; axial sculpture of numerous small, rounded ribs, about 15 to the whorl, extending across the whorl, and feeble varices at intervals of about three-fourths of a whorl; spiral sculpture of fine and coarser rounded threads, thickened a little on top of the ribs; middle portion of whorl nearly flat, with 3 or 5 coarse threads separated by two or more finer ones; margins of the whorls sloping to the moderately impressed suture and covered with fine threads, with one coarser thread adjacent to the suture.

Length of fragment of about 6 whorls, $19.5 \mathrm{~mm}$; width of largest whorl, $8.2 \mathrm{~mm}$.

Two young shells, probably of this species, show that the axial costæ do not extend to the base of the body whorl, which is ornamented with fine, impressed, revolving lines.

Locality.-Crocus Bay, Anguilla, station 6965, Vaughan.

Geologic horizon.-Oligocene.

Type.-U. S. Nat. Mus No. 166991.

Hemisinus costatus, new species.

(Plate 3, Figures $1 a, b$.)

The following is a description of this species:

Shell long, slender; whorls moderately convex; suture deeply channeled. Sculpture of strong axial or slightly protractive costæ, 14 per whorl, terminating abruptly at the first spiral line behind the suture, and 9 or 10 fine revolving threads on whorls of spire and 3 additional strong threads and several finer ones on base of body-whorl. Whorls coronated by a row of weak nodes at the intersections of the most posterior thread with the costæ. Aperture oval; peristome incipiently channeled anteriorly.

Length of fragment of $3 \frac{1}{2}$ whorls, $20.6 \mathrm{~mm}$; ; length of body-whorl, 10.6 $\mathrm{mm}$; ; diameter of body-whorl, $7.5 \mathrm{~mm}$.; length of aperture, $5.3 \mathrm{~mm}$. 
Locality.-Angela Elmira asphalt mine, near Bejucal, Cuba, station 5312, Wiebusch.

Geologic horizon.-Oligocene?

Type.-U. S. Nat. Mus. No. 166994.

Hemisinus bituminifer, new species.

(Plate 3, Figure 2.)

The following is a description of this species:

Whorls convex, obsoletely shouldered; suture impressed; costæ terminating abruptly close behind the suture, retractive in posterior quarter of the shell, protective in anterior three-quarters, 22 on penultimate whorl, 27 on bodywhorl; shoulder nearly smooth; about 10 low, spiral threads on whorls in front of the shoulder; base of body-whorl with numerous fine, even, spiral threads. Aperture broadly oval; inner lip with a thin callus.

Length of a fragment of about $13 / 4$ whorls, $21.7 \mathrm{~mm}$.; altitude of bodywhorl, $16.8 \mathrm{~mm}$.; diameter of body-whorl, $18 \mathrm{~mm}$.; length of aperture, about $10 \mathrm{~mm}$.

Locality.-Angela Elmira asphalt mine, near Bejucal, Cuba, station 3652 , Wiebusch.

Geologic horizon.-Oligocene?

Type--U. S. Nat. Mus. No. 166993.

Hemisinus atriformis, new species.

(Plate 3, Figures 4, 5.)

The following is a description of this species:

Shell stout, of about 8 or 10 whorls, $5 \frac{1}{2}$ remaining on the decollated type; whorls cylindrical to convex, twice as wide as high. Axial sculpture of numerous close, slightly protractive ribs rendered strongly nodose by close impressed revolving lines. The axial sculpture is dominant at first, but is exceeded in strength on the large whorls by the spiral sculpture. Aperture crushed in all the specimens at hand, but apparently broadly oval and flattened in front. Inner lip callous, arcuate; outer lip thin.

Alt., $15.5 \mathrm{~mm}$; diam. of body-whorl, $8 \mathrm{~mm}$.

The sculpture of this shell is strikingly similar to that of plicate varieties of Doryssa atra inhabiting rivers in British Guiana.

This species, much broader than $H$. siliceus, with which it is associated, possesses nearly the same proportions as the cast from the same locality which has been unrecognizably figured by Brown and Pilsbry under the name of $H$. latus. ${ }^{1}$

Locality.-Dry Hill Point, Antigua, station 6867, Vaughan.

Geologic horizon.-Oligocene.

Type.-U. S. Nat. Mus. No. 166996.

\section{Hemisinus antiguensis Brown and Pilsbry.}

(Plate 3, Figures 6, 7, 8, 9.)

Hemisinus antiguensis Brown and Pilsbry, Proc. Acad. Nat. Sci. Phila., p. 210, plate 9, figs. $1,3,5,6,1914$.

1 Proc. Acad. Nat. Sci. Phila., p. 211, plate 9, fig. 4, 1914. 
The following is the original description of this species:

"The shell is slender, diameter contained nearly three times in the length; whorls rather numerous, probably at least fifteen in a perfect shell, as a young one $12.5 \mathrm{~mm}$. long has twelve whorls, the upper part of the spire being very slender. Whorls convex, sculptured with many rounded ribs, as wide as their intervals, somewhat curved, the concavity forward and somewhat protractive. There are about 25 ribs on a whorl. Above the lower suture of each whorl there are two or three spiral cords, the lowest one strongest. On the last whorl the ribs extend to the periphery, where they disappear, the peripheral region and the base having numerous spiral cords. The aperture is but rarely preserved, but in the best examples the peristome seems to be somewhat effuse at the base of the columella.

"Length 16.5, diam. 6 mm., 8 whorls remaining.

"The sculpture of longitudinal ribs with basal spirals is characteristic. The same type of sculpture occurs in various South American species of Hemisinus. It could readily be matched also in Melania and related forms or in the Pleuroceratidæ.

"There seems to be variation in the development of the spirals. Many specimens show weak traces of impressed spirals over the ribs throughout, and this seems to be the normal condition; but in some examples the ribs appear to be smooth except near their lower ends.

"This species, like the associated forms, has the basal sinus or notch obsolete, as in part of the recent species."

The revolving threads on the posterior part of the whorl are coarser and more persistently present than one would infer from the description.

Locality.-Dry Hill Point, Antigua (station 6867), Vaughan.

Geologic horizon.-Oligocene.

Type.-Philadelphia Academy.

Figured specimen.-U. S. Nat. Mus. No. 166995.

\section{Hemisinus siliceus Brown and Pilsbry.}

(Plate 3, Figure 3.)

Hemisinus siliceus Brown and Pilsbry, Proc. Acad. Nat. Sci. Phila., p. 211, plate 9, fig. 2, 1914.

The following is the original description of this species:

"The shell is Melaniiform, regularly tapering, the diameter of last whorl contained about $2 \frac{1}{4}$ times in the total length. The whorls are convex, and apparently without any sculpture except growth-lines. The last whorl has fine, reversed sigmoid growth striæ, which retract somewhat below the suture, then advance, as in H. cubiana. In the type specimen a former peristome, indicating a period of growth arrest, appears as a sigmoid varix on the last whorl. This indicates a more strongly sigmoid outer lip than in the recent Antillean species.

"Length $26 \mathrm{~mm}$., about six whorls remaining, the summit lost; diam. $10.8 \mathrm{~mm}$.

"No entirely perfect aperture was found on the slabs collected, but so far as we can judge, it seems to be much like that of Hemisinus cubanianus (Orb.). It is not unlikely that $H$. siliceus is ancestral, or at least a collateral species 
not far removed from the ancestral stock of the smooth Antillean species of Hemisinus.

"There is, of course, a possibility that this Antigua species belongs to the genus Pachycheilus, which is represented in the recent fauna of Cuba by $P$. conicus (Orb.) and $P$. violaceus Prest.; but the straighter columella does not, in our opinion, favor this view.

"The type has lost the shell from the spire by conversion into flint, but the surface has been preserved in perfection on the last whorl."

Locality.-Dry Hill Point, Antigua, station 6867, Vaughan.

Geologic horizon.-Oligocene.

Type.-Philadelphia Academy.

Figured specimen.-U. S. Nat. Mus. No. 166998.

Turritella anguillana, new species.

(Plate 4, Figures 1, 2,3.)

The following is a description of this species:

Shell long, slender; whorls medially constricted, with two prominent spiral cords on the anterior quarter, the cord adjacent to the suture usually the smaller; remainder of the whorl with fine spiral threads; finer details of sculpture obliterated on specimens at hand.

A fragment of 4 whorls tapers from 11.5 to $8 \mathrm{~mm}$. in $25.5 \mathrm{~mm}$. length.

This species appears to be intermediate between $T$. mississippiensis Conrad from Vicksburg and T. systoliata Dall from the Tampa silex bed, resembling the former in that the posterior of the two prominent cords is the larger, and resembling the latter in the constriction of the whorls.

$T$. anguillana is closely related to $T$. halensis Dall from Bainbridge, but in $T$. halensis the constriction is limited to the middle third of the whorl.

Locality.-Crocus Bay, Anguilla, station 6894, Vaughan.

Geologic horizon.-Oligocene.

Type.-U. S. Nat. Mus. No. 167008.

Turritella dubiosa, new species.

(Plate 4, Figure 4.)

The following is a description of this species:

Shell conic, rapidly expanding; whorls nearly flat or very slightly convex, with a low, sharp, spiral thread at the anterior quarter and a finer thread adjacent to the suture; median portion smooth; posterior third with two or more low, spiral threads; suture very little impressed.

Length of fragment of about 5 whorls, $26 \mathrm{~mm}$.

This species is represented in the collection by a single slightly crushed fragment. The figure is from a photograph of the broader side.

Locality.-Crocus Bay, Anguilla, station 6965, Vaughan.

Geologic horizon. - Oligocene.

Type.-U. S. Nat. Mus. No. 167009. 


\section{Turritella forresti Brown.}

(Plate 4, Figures 5, 6, 7.)

Turritella forresti Brown, Proc. Acad. Nat. Sci. Phila., p. 613, plate 20, figs. 2, 3, 4, 7; 8, 1913 .

The following is the original description of this species:

"Shell elongate, slowly tapering, of many whorls, with a raised sculpture of three major spiral ridges, of which the one towards the apex is double and beaded, the next one is at first single, but later becomes double and beaded, while the third is, in the younger stage, not beaded. Between these major revolving spiral ridges are finer revolving spirals, about five between the first and second major spirals, and the same number between the second and third spirals, with a like number from the third spiral to the suture. These secondary spirals may become knotty and beaded when crossed by the diagonal growth lines, and the doubling of the major spirals comes from one of these minor spirals becoming enlarged on that side of the major spiral towards the apex. The suture becomes depressed by the shell being excavated above the suture or on the basal side of the whorl. A fragment of $14 \mathrm{~mm}$. tapers from 4 $\mathrm{mm}$. to $2 \mathrm{~mm}$. in six whorls. A larger fragment tapers from $6 \mathrm{~mm}$. to $4 \mathrm{~mm}$. in a length of $13 \mathrm{~mm}$."

Localities.-North of the cathedral, St. Johns, Antigua, station 6866, Vaughan; Willoughby Bay, Antigua, Brown.

Geologic horizon.-Oligocene.

Types.-Philadelphia Academy, No. 1644.

Figured specimens.-U. S. Nat. Mus. No. 167005.

Turritella crocus, new species.

(Plate 4, Figure 8.)

The following is a description of this species:

Shell acute-conic; whorls nearly twice as wide as high, with 2 strong, high, revolving ribs separated by a deep, evenly concave depression; anterior rib round to acutish, with concave slope to the suture; posterior rib round, with flattish posterior slope to the suture; suture deeply impressed; obscure traces of revolving, impressed lines on median depression and on posterior rib; base nearly flat; aperture oval or subquadrangular.

Alt. of decollated specimen, 4 whorls remaining, $28 \mathrm{~mm}$; diam. of bodywhorl, $11.9 \mathrm{~mm}$. The body-whorl of a larger specimen measures $18.5 \mathrm{~mm}$. in diameter.

The median groove of this species recalls $T$. ambulacrum Sby., but comparison shows the latter to be entirely distinct.

A very closely related, if not identical, species occurs in limestone at "E-1 Salts," Chiapas, Mexico, in the area marked as Pliocene by Böse.

Localities.-Upper bed at Crocus Bay, Anguilla, stations 6967 (type), 6894, and 6893. A fragment, apparently of $T$. crocus, was found at Willoughby Bay, Antigua, station 6881, and another, possibly of the same species, near Jackass Point, St. Johns Bay, Antigua, station 6865.

Geologic horizon.-Oligocene.

Type.-U. S. Nat. Mus. No. 167000. 
Solarium species.

(Plate 4, Figure 10.)

From Crocus Bay, Anguilla, there are two specimens of Solarium. The smaller, which is figured, is a fragment of $3 \frac{1}{2}$ whorls from station 6965. The upper surface is ornamented with a sculpture of radiating and revolving lines, as in S. bellastriatum; the lower surface is embedded in a matrix of hard, yellow limestone. The larger specimen is $23 \mathrm{~mm}$. in diameter. The sculpture, except for prominent revolving lines on the upper surface, is obliterated. The suture is deeply impressed.

Locality.-Crocus Bay, Anguilla, stations 6965 and 6967, Vaughan. Geologic horizon.-Oligocene.

Figured specimen.-U. S. Nat. Mus. No. 167015.

Bythinella antiguensis Brown and Pilsbry.

Bythinella antiguensis Brown and Pilsbry, Proc. Acad. Nat. Sci. Phila., p. 212, text-fig. 1, 1914.

The following is the original description of this species:

"The shell is oblong, pupiform, smooth; outlines of the spire convex, the apex conspicuously obtuse. Whorls 4 , very convex, aperture vertical, shortly ovate, its length contained $2 \frac{1}{2}$ times in that of the shell; peristome in one plane, thin.

"Length 1.8, diam. 1.1, length of aperture $0.7 \mathrm{~mm}$.

"This very minute form is not rare. It has the very obtuse summit and the pupiform shape of the species usually referred to Bythinella, rather than the shape of Paludestrina, if, indeed, the two groups are distinct. Of course, any generic reference of a minute Amnicoloid shell of this sort is purely provisional, unless it is from a region where the recent fauna and its antecedents are well known."

Locality.-Dry Hill, Antigua, Brown.

Type.-Philadelphia Academy.

\section{Xenophora species.}

A species of Xenophora with very convex, closely appressed whorls showing few scars of attachment is abundant in the Oligocene of Crocus Bay, Anguilla (stations 6893, 6894, 6966, 6967). An indeterminable cast of a Xenophora was collected from the upper Eocene on the northwest side of St. Jean Bay, St. Bartholomew, station 6925, Vaughan, collector.

\section{Genus ELMIRA, new genus.}

The following is a description of this genus:

Shell rapidly increasing in size; whorls few, rapidly descending; holostome; imperforate.

Genotype.-Elmira cornu-arietis Cooke, $\mathrm{n}$. sp.

This genus appears to belong to the Paludinidæ, but has fewer whorls and is much more rapidly expanding than the other members of that family. 
Elmira cornu-arietis, new species.

(Plate 5, Figures $9 a-c$.)

The following is a description of this species:

Shell corniform, imperforate, thin, rapidly increasing in size, with 2 evenly convex rapidly descending whorls; suture deeply impressed; aperture entire, circular; inner lip and part of the convex base concealed by a thin callus; surface malleated and with obscure broad revolving grooves crossed by rugose, undulating growth-lines.

Axial elevation, $32 \mathrm{~mm}$.; diameter, $34 \mathrm{~mm}$.

As the shell is broken away at the apex, the apparent fewness of volutions may be due, in part, to the obliteration of the sutural impressions in the asphalt of which the cast is composed.

Locality.-Angela Elmira asphalt mine, near Bejucal, Cuba, stations $3652,5312$.

Geologic horizon.-Oligocene?

Type.-U. S. Nat. Mus. No. 167036.

Ampullina anguillana, new species.

(Plate 4, Figures $9 a, b$.

The following is a description of this species:

Shell globose, of about $5 \frac{1}{2}$ whorls, striated in accordance with the lines of growth at intervals on the body-whorl of about $0.6 \mathrm{~mm}$.; spire low; base covered with a broad, convex callus.

Alt., $43 \mathrm{~mm}$.; diam., $42.5 \mathrm{~mm}$.

This shell resembles $A$. fischeri Dall, which has a flatter and proportionately much narrower callus. The shape of the whorls and the elevation of the spire are about as in $A$. fischeri.

Localities.-Crocus Bay, Anguilla, station 6965 (type), 6966, 6893?, 6894, Vaughan, collector; also in the form of casts at Consolacion del Sur, Cuba, station 3474 , the Alcalde, collector.

Geologic horizon.-Oligocene.

Type-U. S. Nat. Mus. No. 167021.

Ampullina (?), indeterminate species.

An indeterminable cast.

Locality.-Between Colombier Point and bay next to St. Jean Bay, St. Bartholomew, station $6897 b$, Vaughan.

Geologic horizon.-Upper Eocene.

Ampullina (Ampullinopsis) spenceri, new species.

(Plate 5, Figures 1-3.)

The following is a description of this species:

Shell large, thick, of about 7 whorls; the entire body-whorl, except the base and sutural channel, ornamented with close, evenly spaced, indistinct, impressed punctate revolving lines, visible only on well-preserved specimens; apex small, pointed; spire moderately low; suture deeply excavated; whorls angulated at the sutural channel; greatest convexity below the middle of the whorl; base flat or slightly convex, separated from the remainder of the body- 
whorl by a distinct, sometimes impressed line; callus turgid, of variable width, usually concealing much of the umbilicus.

$\begin{array}{ccc}\text { Dimensions-Alt., } 38 \mathrm{~mm} \text {.; diam., } & 39 \mathrm{~mm} \text {; length of body-whorl at aperture, } 35.5 \mathrm{~mm} . \\ 37 & 38.5 & 35.0 \\ 53.5 & 55 & 50.5\end{array}$

This species closely resembles A. amphora Heilprin, but the spire is less elevated than in that species.

Locality. - The two cotypes were collected by J. W. Spencer in Antigua; a larger but less perfect specimen was obtained by Vaughan at the bluff on the north side of Willoughby Bay, Antigua (station 6881). Casts of a similar, perhaps identical, species were collected at Crocus Bay, Anguilla (station 6894).

Geologic horizon.-Oligocene, Antigua formation.

Types.-U. S. Nat. Mus. No. 167031.

\section{Sinum chipolanum (Dall)}

(Plate 5, Figures $6 a, b$.)

Sigaretus chipolanus Dall, Trans. Wagner Inst., vol. 3, pt. 2, p. 379, plate 17, fig. 7, 1892.

Sinum chipolanum Dall, U. S. Nat. Mus. Bull. 90, p. 109, plate 12, fig. 29; plate 16, fig. 1, 1915.

The following is the original description of this species:

"Shell solid, rather thick, varying in rotundity with age, the young ones as a rule being more naticoid in shape, while the more advanced are relatively flatter, and the fully mature specimens again are more rotund; whorls four or five, sculptured with rather fine, flattish, revolving threads of varying size, separated by channelled interspaces, varying in width and minutely undulated or reticulated by the sharp, close-set, fine incremental lines; aperture large, oblique; base somewhat flattened, periphery rounded; pillar lip arched, broad, flattened somewhat and sometimes excavated, with a narrow sulcus behind it, running up to the imperforate umbilical region; callus on the body moderate, lip not reflected. Max. lon. of adult 33; diam. $27 \mathrm{~mm}$.; lon. of young shell 16.5; axial elevation 11 ; diam, $15 \mathrm{~mm}$.

"This species is most nearly related to $S$. declivis, from which it may be separated by its closed umbilicus and the absence of the emargination of the pillar, which is the most characteristic feature of declivis. It also recalls $S$. bilix var. mississippiensis, which has a perforate umbilicus and is more rotund. The sculpture may be close or sparse; it varies in this respect in nearly all the species."

The specimen from Anguilla is more depressed and much less rotund than is customary for $S$. chipolanum, but comes well within the range of variability of that species in those respects. It is very much less rotund than the form from the Tampa "silex" bed, which may be specifically distinct from $S$. chipolanum.

The dimensions of the figured specimen are as follows: max. lon., $16.9 \mathrm{~mm}$.; axial elevation, $10 \mathrm{~mm}$.; diam., $11 \mathrm{~mm}$.

Localities.-Crocus Bay, Anguilla, station 6894,Vaughan;also Chipola.

Geological horizon.-Oligocene.

Type.-U. S. Nat. Mus. No. 112967.

Figured specimen.-U. S. Nat. Mus. No. 167033. 
Turbo antiguensis, new species.

(Plate 5, Figures $4 a-c$.)

The following is a description of this species:

Spire moderately elevated, imperforate; whorls convex, with greatest diameter below the middle of the whorl; suture impressed; surface covered with revolving rows of nodules, about 20 on the body-whorl; on the bodywhorl the nodules of the 3 or 4 rows nearest to the suture are elongated obliquely and fused with those of the adjacent rows, producing falsely protractive ribbing; remaining nodular rows alternating in size; secondary sculpture of fine revolving threads within the internodular and interfilar spaces on the base, but not crossing the nodes.

Alt., $23 \mathrm{~mm}$.; diam., $24 \mathrm{~mm}$.

This species resembles in shape and size Turbo crenorugatus Heilprin from the Tampa "silex" bed, but is differently sculptured; it is probably related to the unfigured T.dominicensis Gabb from Santo Domingo.

Locality.-Rifle Butts, Antigua, station 6854, Vaughan.

Geologic horizon.-Oligocene.

Type.-U. S. Nat. Mus. No. 167034.

\section{Turbo species.}

The following is a partial description of this species:

One mold of a Turbo with a high spire. The sculpture of the whorls above the carina is indistinct, but several revolving threads are visible. The base of the shell is ornamented with 4 or 5 strong revolving threads between which are several smaller beaded threads. The basal fasciole is rather large and prominent.

Alt., about $23 \mathrm{~mm}$.; diam., about $20 \mathrm{~mm}$.

This species is quite distinct from T.antiguensis and T.crenorugatus and appears to be undescribed.

Locality.-Consolacion del Sur, Cuba, station 347.4, the Alcalde, collector.

Geologic horizon.-Oligocene.

\section{Margarita naticoides, new species.}

(Plate 5, Figures $5 a, b$.)

The following is a description of this species:

Shell naticoid, polished, pearly within, smooth except for fine growth-lines; whorls $3 \frac{1}{2}$, strongly convex anteriorly, but flattened or slightly concave in front of the suture; suture distinct; spire low; base convex; aperture circular; outer lip attenuated, inner lip incrassated; umbilicus rudimentary.

Alt., $10.5 \mathrm{~mm}$.; width, $11.4 \mathrm{~mm}$.; length of aperture, $8 \mathrm{~mm}$.

Locality.-Angela Elmira asphalt mine, near Bejucal, Cuba, stations 3652,5312 , Wiebusch, collector.

Geologic horizon.-Oligocene?

Type.-U. S. Nat. Mus. No. 167028. 
Neretina? grandis, new species.

(Plate 5, Figures 7, 8.)

The following is a description of this species:

Shell large, rapidly expanding; younger whorls shouldered, older whorls rounded; spire very low, largely covered by body-whorl; suture not impressed; inner walls resorbed.

Alt., about $32 \mathrm{~mm}$.; width, $35 \mathrm{~mm}$.

The generic position of this species is puzzling. The resorption of the inner walls of the shell, as shown in casts of the interior, ally it with the Neritidæ rather than with the Naticidæ, to which it bears a superficial resemblance. The young shell shows a rather close resemblance in shape and size to some of the species of Neritina living on the west coast of America, but the mature shell attained a length of nearly 8 cm., much larger than any of the known species of that genus. In size and general appearance the species is not unlike the genus Velates of the Eocene of the Paris Basin, but appears to lack the superficial shelly layers which conceal the suture in that genus.

The columellar lip in all the specimens at hand is concealed by the hard matrix.

Localities.-Anse Lézard and St. Jean Bay, St. Bartholomew, stations 6926 (type) and 6925, Vaughan. A cast of a species resembling this in size and shape was obtained recently by me from the Ocala limestone at the Holder phosphate mine, 5 miles southwest of Inverness, Florida.

Geologic horizon.-Upper Eocene.

Type.-U. S. Nat. Mus. No. 167038.

Planorbis siliceus Brown and Pilsbry.

Planorbis siliceus Brown and Pilsbry, Proc. Acad. Nat. Sci. Phila., p. 212, plate 9, figs. 1a, $3 a, 5 a, 6 a, 1914$

The following is the original description of this species:

"This is a species of the section Tropicorbis. The shell is rather thick, with the periphery rounded, more convex towards the right side. The two sides are about equal in width of the concavity, but that on the right side penetrates more deeply, being vortex shaped. The last whorl is rounded on this side. On the left side the last whorl is subangular and the cavity is less infundibuliform.

"Diameter 3.5, greatest alt. $1.7 \mathrm{~mm}$.

" 5 " " 2.1 "

"This species belongs to a widely spread group of the modern tropical American fauna."

Locality.-Dry Hill Point, Antigua, station 6867, Vaughan.

Geologic horizon.-Oligocene.

Type.-Philadelphia Academy. 
Scapharca (Scapharca) anguillana, new species.

(Plate 5, Figures $10 a, b$.)

The following is a description of this species:

Shell of moderate size, inequilateral, with elevated prosocolous beaks situated at the anterior third; right valve with 31 rounded ribs separated by flat interspaces of equal width, the ribs on the anterior end set with erect rounded, disk-like tubercles with longer axis parallel to the lines of growth and separated by narrower spaces; on the remaining ribs the tubercles are replaced by low nodes which become obsolete near the posterior end of the shell; left valve unknown; cardinal area with a raised margin, high, with about 8 wavy grooves; hinge-line short, with about 58 teeth, small and vertical mesially, larger and oblique distally. $22 \mathrm{~mm}$.

Alt., $30 \mathrm{~mm}$.; lon., $32 \mathrm{~mm}$.; diam. of right valve, $8 \mathrm{~mm}$.; length of hinge,

This species is very closely related to A. chiriquiensis Gabb from Chiriquí, Panama, from which it can be distinguished by the smaller size and much greater number of tubercles on the Anguillan species.

Locality.-Crocus Bay, Anguilla, station 6964, Vaughan.

Geologic horizon.-Oligocene.

Type.-U. S. Nat. Mus. No. 167044.

\section{Scapharca willobiana, new species.}

(Plate 5, Figures $11 a, b$.)

The following is a description of this species:

Shell of moderate size, elliptical, with low beaks situated at the anterior third. Valves with about 35 ribs with fine, regular, concentric beading, except on the posterior slope, where the ribs are almost smooth; near the margin the ribs are flattened and some of them show an incipient channeling which probably becomes more pronounced on larger shells. Hinge line long, straight. Both ends of shell rounded, the anterior with shorter radius than the posterior. Spaces between the ribs nearly equal in width to the ribs and crossed by evenly spaced, raised lines continuous with the beads on the ribs. Cardinal area long and narrow.

Long., $23 \mathrm{~mm}$.; alt., $15 \mathrm{~mm}$.; diam., $9 \mathrm{~mm}$.

The type is a young specimen which has been crushed in the umbonal region but is otherwise well preserved.

This species may be distinguished from Scapharca hypomela Dall by its much more elliptical outline, rounded margins, and fewer ribs.

Locality. - North side of Willoughby Bay, Antigua, station 6881, Vaughan.

Geologic horizon.-Oligocene.

Type.-U. S. Nat. Mus. No. 167040.

Pinna vaughani, new species.

(Plate 9, Figures $4 a, b$.)

The following is a description of this species:

Shell rapidly expanding, valves mesially carinate; sculpture of longitudinal riblets about 7 on dorsal area and about 5 below the carina, lower half of ventral area smooth, except for growth lines.

Length of fragment, $58 \mathrm{~mm}$.; height, $37 \mathrm{~mm}$.; depth, $28 \mathrm{~mm}$. 
A single fragment was collected by Dr. Vaughan, in whose honor the species is named. It is broken at both ends and has been rendered somewhat unsymmetrical by pressure, which has also increased the acuteness of the carinal angles.

This species is not unlike $P$. carnea Gmelin, but that species has rudimentary riblets on the lower part of the ventral area.

Locality.-Crocus Bay, Anguilla, station 6894, Vaughan.

Geologic horizon.-Oligocene.

Type-U. S. Nat. Mus. No. 167047.

Ostrea antiguensis Brown.

(Plate 6, Figures $1 a, b, 2 a, b$.)

Ostrea antiguensis Brown, Proc. Acad. Nat. Sci. Phila., p. 614, plate 19, fig. 7; plate 20. figs. 1, 5, 6; 1913.

The following is the original description of this species:

"Shell ovate or nearly orbicular, thick and dense, externally radially plicate or sometimes nearly smooth, the plications on the lower, deep valve begin at the beak and are usually seven in number, of which a group of five ridges is separated from the other two by a broad depression; the ridges sharp and spinose or obtuse and even, the furrows or depressions smooth and rounded. Hinge moderate, the shell rapidly widening beyond the end of the hinge line, the plications usually dying away as the margin of the adult shell is reached, and this margin in the lower valve being turned up abruptly for one-half inch or more, making a cup-shaped valve. The muscle impression is distinct, more strongly impressed in the case of the deep valve; situated on the left and nearer to the beak than to the opposite margin. The lower valve is more or less excavated internally, the upper valve is flat. When strongly plicate and even spinose, this species closely resembles $O$. gatunensis B. and P., except that this latter species has not the heavy shell of $O$. antiguensis nor has it the turned-up margin. $O$. haitensis Sowb. has the rugose exterior of this species in its strongly plicate form, but while the shell is heavy, it lacks the upturned edge of $O$. antiguensis. Length $85 \mathrm{~mm}$., alt. $80 \mathrm{~mm}$., depth of lower valve $30 \mathrm{~mm}$.

"In size and plication $O$. antiguensis varies largely, but of the specimens collected the longest shells do not run far from $90 \mathrm{~mm}$. in altitude. As regards plication, some are nearly smooth and some are strongly rugose, even in some cases spinose, but all may be distinguished by the broad furrow which runs across the exterior of the lower valve about opposite to the muscle impression and which divides the rugæ into a group of five and one of two. The species differs also from all other closely related American species by the upturned margin of this lower valve and the correspondingly reflexed margin of the upper or flat valve."

This is a heavy, massive species, resembling, in that respect, $O$. podagrina Dall. The broad depression on the lower valve, although usually present, is not a constant feature, but is occasionally absent, even on plicate individuals. A rather persistent character is a long, crescent-shaped excavation on the interior of the lower valve, extending practically the entire length of the shell. The upturning and reflexing of the margins, mentioned by Professor Brown, is not a noticeable feature of the specimens in the Vaughan collection. 
Localities.-Rifle Butts, Wetherell Point, Hodge's Bluff, Long Island, Blizzard Mill, and, doubtfully, 0.5 mile north of McKinnon's Mill, and Friar's Hill, Antigua, stations 6854, 6858, 6862, 6869, 6874, $6888,6856,6875$, Vaughan.

Types.-Philadelphia Academy of Sciences, Nos. 1653 and 1655.

Figured specimens.-U. S. Nat. Mus. No. 167055.

Ostrea species, cf. O. trigonalis Conrad.

(Plate 9, Figure 1.)

?Ostrea trigonalis Conrad, Proc. Acad. Nat. Sci. Phila., vol. 7, p. 259; figured in Wailes's Geol. Agric. of Miss., plate 14, fig. 10, 1855.

?Ostrea podagrina Dall, Proc. U. S. Nat. Mus., vol. 18, p. 22, 1895.

?Ostrea podagrina Dall, Trans. Wagner Inst., vol. 3, pt. 4, p. 682, plate 30, figs. 5, 6, 1898.

This large, massive species resembles Ostrea trigonalis in the character of its hinge, which is broad, straight, and separated into thirds by a deep triangular pit in each valve. In front of the hinge the shell continues at about the width of the hinge-line for about $1 \mathrm{~cm}$., beyond which it is rapidly expanding. The lower valve is very highly inflated and broadly plicate, much as in $O$. podagrina and in the plicate forms of $O$. trigonalis and $O$. vicksburgensis, all three of which appear to be closely related and may be merely varieties of one species.

Localities.-Northwest side of St. Jean Bay, St. Bartholomew, stations 6924 and 6925 . Fragments, probably of the same species, were obtained at station 6895 and at Governor's Bay, station 6919, Vaughan.

Geologic horizon.-Upper Eocene.

Figured specimen.-U. S. Nat. Mus. No. 167056.

Ostrea haitensis Sowerby.

(Plate 7, Figures 1, 2; Plate 8, Figure 1.)

Ostrea haitensis, Sowerby, Quart. Jour. Geol. Soc. London, vol. 6, p. 53, 1850.

O. heermanni Conrad, Proc. Acad. Nat. Sci. Phila., vol. 5, p. 267, 1853.

O. heermanni Conrad, Pac. R. R. Rept., vol. 5, p. 326, 1855.

O. vespertina Conrad, Pac. R. R. Rept., vol. 5, p. 325, plate 5, figs. 36-38, 1855.

O. virginica var. californicum Marcou, Geol. N. Amer., 1858.

O. virginica Guppy, Quart. Jour. Geol. Soc. London, vol. 22, p. 577; not of Gmelin; 1866.

O. vespertina Gabb, Pal. Cal., vol. 2, p. 107, 1869.

O. veatchii Gabb, Pal. Cal., vol. 2, p. 34, plate 11, fig. 59; plate 17, fig. 21, 1869.

O. haytensis Gabb, Trans. Amer. Phil. Soc, n. 8., vol. 15, p. 257, 1873.

O. haitensis Dall, Trans. Wag. Inst., vol. 3, pt. 4, p. 685, 1898.

O. haitensis Joukowski and Clerc, Mém. Soc. Phys. et d'Hist. Nat. de Genève, vol. 35, p. 170, plate 6 , figs. $20-23,32-35,1906$.

O. haitensis Maury, Bull. Amer. Pal., vol. 5, p. 346, plate 57, figs. 1, 2, 1917.

The following is the original description of this species:

"Testa oblonga, crassa, plicata, plicis paucis (senis ad septenis), magnis, undulatis, subsquamosis, squamis nonnumquam subtubulosis; limbo interno omnino glabro."

Two forms of this species are known from Cuba. The first is a large, heavy shell with close, acute, angular plicæ. The number of plicæ is variable; some specimens have 12 or more. The other form, which is probably the young of the same species, is much smaller, usually not 
plicate, with a long, narrow, usually curved hinge. The valve margins from the tip of the hinge to about the middle of the shell are dentate in the upper valve and correspondingly punctate in the attached valve.

Localities.-East of La Cruz and northeast of Santiago, Cuba, stations 3441,3443 , and 5255. A large specimen, probably of this species, comes from the gorge of Yumuri River, Cuba, station 3454, Vaughan. Guajay, Cuba, Barnum Brown.

Type.-British Museum?

Figured specimens.-U. S. Nat. Mus. Nos. 167059, 167061, 167062.

Unio bitumen, new species.

(Plate 9, Figures $3 a-c$.)

The following is a description of this species:

Shell elongate, moderately inflated, inequilateral; beaks high, apparently smooth; posterior ridge high near the umbones, becoming broad and low distally. A broad depression extends from the umbones to the middle of the ventral margin, producing a concavity in the ventral margin. Anterior margin acutely rounded; posterior margin broadly rounded; dorsal margin arcuate. Hinge unknown. Ligament external, preserved in the type.

Length, $68 \mathrm{~mm}$.; diameter, $29.5 \mathrm{~mm}$.

The name Unio is here used in the broad sense, the material at hand being insufficient to determine the precise generic position of this species.

Locality.-Angela Elmira asphalt mine, near Bejucal, Cuba, station 3652 , Wiebusch, collector.

Geologic horizon.-Oligocene?

Type.-U. S. Nat. Mus. No. 167063.

Pecten (Pecten) ventonensis, new species.

(Plate 12, Figures $1 a, b$.)

The following is a description of this species:

Shell large, equilateral, inequivalve; right valve convex, with 23 to 25 rather high ribs, flattened on top, usually medially furrowed and closely transversely grooved or granulate, and separated by equal concave interspaces; left valve concave, with 23 or 24 narrow, even, rounded ribs, becoming obsolete towards the lateral margins, separated by wider, nearly flat interspaces; right submargins small, plane to convex, nearly smooth; left submargins strongly convex, narrow, nearly smooth; ears subequal, nearly straight, with a few narrow, obsolescent riblets, strongest on the right anterior ear; byssal notch shallow; both valves grooved internally in accordance with the external ribbing; secondary sculpture of fine, close, raised, concentric lamellæ, extending over disk and ears alike, but very faint on the submargins and usually eroded from the ribs of the convex valve.

Alt., $39 \mathrm{~mm}$.; lat., $42 \mathrm{~mm}$; diam., $11 \mathrm{~mm}$.

This species is closely related to Pecten medius Lam., living off the southern Atlantic and Gulf coasts of the United States, from which it differs as follows: On the right valve the ribs of the fossil extend nearer 
to the beak, are higher, narrower, and more rugose than in $P$. medius; the number of ribs is within the range of variation of $P$. medius, but is less by one or two than the average for specimens of the same size. On the left valve the ribs are a little closer together and the lateral margins are less flaring than in $P$. medius. The right ears are about as in $P$. medius, but the left ears lack the two strong ribs which are nearly always present near the hinge line on each left ear of the living species.

Localities.-One-half mile inland from the pier of the Juraguá Railroad, Santiago Bay, Willcox; Juraguá Railroad, La Cruz, first cutting on road, Vaughan; Vento, province of Havana, Wren; stations 3192, $3439,4290,5255$.

Geologic horizon. Yigocene.

Type.-U. S. Nat. Mus. No. 167102.

\section{Pecten perlatus, new species.}

(Plate 13, Figure 3.)

The following is a description of this species:

Shell small, suborbicular, tumid; ribs 16 , simple except near the margin, where each contains 3 riblets; interspaces as wide as the ribs; concentric sculpture of raised, widely spaced growth lines, apparently confined to the interspaces; submargins with close radial riblets which form an uninterrupted series with those on the ears; ears large, equal, finely radially ribbed, scarcely differentiated from the submargins.

Alt., $11 \mathrm{~mm}$.; lat., $12 \mathrm{~mm}$.

Locality.-Crocus Bay, Anguilla, station 6966, Vaughan.

Geologic horizon.-Oligocene.

Type--U. S. Nat. Mus. No. 167068.

Pecten (Chlamys) waylandi, new species.

(Plate 7, Figures $4 a, b$.)

The following is a description of this species:

Shell medium-sized, nearly equilateral, equivalve, with about 30 low ribs with equal interspaces becoming obsolete towards the depressed submargins; posterior ears small, oblique, with 4 or 5 faint radial riblets; anterior ears much larger, with about 12 faint riblets on left ear and 5 or 6 somewhat coarser riblets on right ear; byssal notch about one-half the length of the ear; inner margin fluted in accordance with the external ribbing in channels which probably extend well towards the center of the disk.

Alt., $32.3 \mathrm{~mm}$.; lat., $29 \mathrm{~mm}$.; diam., $12.5 \mathrm{~mm}$.

Although the single specimen upon which this species is founded has lost so much of the external part of the shell that it is impossible to make out the details of sculpture, the ears, as well as the outline and major sculpture of the shell, are so well preserved that it seems worth while to describe it. The species is not apt to be confused with any other of this region. It is named in honor of Dr. T. Wayland Vaughan.

Locality.-Santiago Cuba, station 3440, Vaughan.

Geologic horizon. -

Type.-U. S. Nat. Mus. No. 167121. 


\section{Pecten (Chlamys) anguillensis Guppy.}

(Plate 10, Figures $1 a, b, 2$.)

Pecten anguillensis Guppy, Proc. Sci. Asso. Trinidad, p. 175, 1867.

Pecten anguillensis Guppy, Geol. Mag., Dec. 2, vol. 1, p. 446, plate 18, fig. 24, 1874.

Pecten (Chlamys) anguillensis Dall, Trans. Wagner Inst., vol. 3, pt. 4, p. 715, 1898.

Pecten (Chlamys) anguillensis Brown, Proc. Acad. Nat. Sci. Phila., p. 602, 1913.

The following is Guppy's original description of this species, December 1867:

"Shell fan-shaped, ornamented with radiate muricate striæ, and about 10 or 11 prominent rounded ribs, which are crossed by concentric striæ, the concave interstices broader than the ribs. Upper valve nearly flat, lower one gently concave.

"Miocene, Anguilla. Allied to $P$. peedeensis Tuomey and Holmes, North America."

The following diagnosis was made from one of Guppy's specimens which agrees perfectly in size and shape with the published figure of $P$. anguillensis and is probably the type specimen. If such is the case the figure is very bad. The Guppy collection contains two other specimens, one an internal cast which shows that the shell is grooved internally in accordance with the external ribbing. A fourth specimen in the same lot belongs to a different species (Pecten perplexus).

Shell oblique; right valve the more convex, with 12 or 13 ribs, left valve flatter with 11 ribs; ribs high, round, with equal or slightly wider interspaces; ribs and interspaces covered with radiating threads; submargins narrow, steep, apparently smooth; ears small, unequal, with radiating riblets, anterior the larger.

Alt., $32.8 \mathrm{~mm}$.; lat., $30 \mathrm{~mm}$; diam., $11 \mathrm{~mm}$.

Pecten anguillensis appears to be much more abundant in Antigua than in Anguilla. The Antiguan specimens have as many as 15 ribs and are somewhat variable in convexity and in the shape and elevation of the ribs. The ribs are broader and not so high as in the specimens from Anguilla, and the radiating threads are wider spaced and more elevated; the latter character may be due to the better state of preservation of the Antiguan specimens.

Localities.-Anguilla, Guppy; Crocus Bay, Anguilla; Hodge's Bluff, Willoughby Bay, and Friar's Hill, Antigua, Vaughan, stations 6893, 6862, 6881, 6856. Professor Brown records the species also from Wetherell's Bay, Antigua.

Geologic horizon.-Oligocene.

Type.-Probably the specimen figured in this paper (figs. $1 a, b$ ).

Figured specimens.-U. S. Nat. Mus. Nos. 115532 (type), 167097.

\section{Pecten clevei, new species.}

(Plate 10, Figures 3, 4.)

The following is a description of this species:

Left valve gently convex, with about 21 small concave ribs, somewhat variable in size, with nearly equal interspaces; concentric sculpture of minute 
growth-lines visible on submargins and interspaces but eroded on ribs and ears; 2 or 3 posterior ribs have distant curved imbricating lamellæ convex towards the beak; submargins convex, without ribs, not sharply differentiated from the ears; ears depressed below the plane of the disk; left anterior ear large, acutely oblique, with 4 strong, smooth ribs; left posterior ear small, obtusely oblique, with 2 or 3 faint riblets.

Right valve equilateral, gently convex, with about 20 regular convex ribs, with nearly equal interspaces, in each of which appears a single thread; ribs and threads of anterior end with distant, curved lamellæ like those on the left valve; minute, close growth-lines visible in interspaces of anterior end, but eroded from the remainder of the valve.

Long. of right valve, $30 \mathrm{~mm}$.

The right and left valves have been described separately because of the possibility that they may prove to belong to different species. The left valve is the type.

Locality.-Crocus Bay, Anguilla, stations 6894 and 6965 (type), Vaughan.

Geologic horizon.-Oligocene.

Type.-U. S. Nat. Mus. No. 167094.

\section{Pecten willobianus, new species.}

(Plate 11, Figures 1, 2, 3.)

The following is a description of this species:

Shell equivalve, nearly equilateral, with 18 or $19 \mathrm{smooth}$, rounded ribs with equal interspaces; interspaces with low riblets peripherally; submargins smooth, convex, sharply delimited from the ears; ears large, smooth, except the right anterior ear, which is radially ribbed; internal ventral margins with short flutings in harmony with the radial sculpture.

Alt., $30 \mathrm{~mm}$.; lat., $29 \mathrm{~mm}$.; diam., $10 \mathrm{~mm}$.

Locality.-Willoughby Bay, Antigua, station 6881, Vaughan.

Geologic horizon.-Oligocene.

Types.-U. S. Nat. Mus. No. 167119.

\section{Pecten vaughani, new species.}

(Plate 8, Figures 2, 3, 4.)

The following is a description of this species:

Shell small, compressed, equivalve, equilateral, with 14 or 15 smooth, rounded ribs on right valve, 15 to 17 on left, separated by nearly equal, rounded interspaces; microscopic sculpture of fine, close, concentric lines; submargins smooth, steep; ears of left valve nearly equal, smooth, ears of right valve unequal, anterior ear with about 5 radiating, scabrous riblets; byssal notch one-half the length of the ear; posterior ear smooth.

Alt., $16 \mathrm{~mm}$.; lat., $16 \mathrm{~mm}$; d diam., about $5 \mathrm{~mm}$.

Locality.-Crocus Bay, Anguilla, stations 6894 (type), 6893, 6965, 6967, Vaughan.

Geologic horizon.-Oligocene.

Type.-U. S. Nat. Mus. No. 167084. 
Pecten vaughani var. flabellum, new variety.

(Plate 8, Figures $6 a, b, 7$.)

The following is a description of this variety:

Shell small, equivalve, depressed, polished, with 15 round, radiating ribs, rarely extending to the beaks, separated by equal concave interspaces; submargins narrow, smooth, convex, usually separated from the body of the shell by an angulation; concentric sculpture of close, fine growth-lines, usually obliterated; ears large, subequal; posterior ears smooth except for fine growthlines; left anterior ear with obscure radiating riblets, right anterior ear with about 6 strong scabrous riblets; byssal notch about one-half the length of the ear; interior of the disk grooved in accordance with the ribbing.

Alt., $22 \mathrm{~mm}$.; lat., $22 \mathrm{~mm}$; diameter of joined valves, about $7 \mathrm{~mm}$.

Pecten vaughani closely resembles this variety, but is usually a little smaller, the ribs are narrower and generally extend to the beak, and the submargins are flatter and more acutely angulated than those of the Cuban form. In general appearance typical Pecten vaughani is neater and more clean-cut than the variety flabellum.

Localities.-La Cruz and Santiago, Cuba, stations 3192, 3439, 3441, 3446 , and 5255 (types, Yaughan, Black.

Geologic horizon.-

Type.-U. S. Nat. Mus. No. 167089.

\section{Pecten gardneræ, new species.}

(Plate 7, Figures 5, 6.)

The following is a description of this species:

Right valve inflated, with 15 round ribs a little wider than the interspaces; submargins slightly convex, steep; anterior ear with about 6 radiating riblets, byssal notch one-half the length of the ear; posterior ear large, nearly rectangular; sculpture of close, minute growth-lines over entire shell.

Alt. of right valve, $21 \mathrm{~mm}$.; lat., $21.5 \mathrm{~mm}$.

Left valve flatter, with about 16 even, rounded ribs a little narrower than the interspaces; submargins convex, steep; anterior ear acutely oblique, with two or three very faint, broad, radiating riblets; posterior ear rectangular; concentric sculpture of minute, elevated, very close-set lines extending over entire shell, but on the disk grouped into bands or growth stages about 0.3 $\mathrm{mm}$. wide.

Alt. of left valve, $22.6 \mathrm{~mm}$; lat., $22.3 \mathrm{~mm}$.

The right valve is much more convex and appears less spreading than the left, and the concentric sculpture is much less distinct. This last feature is probably due to the better state of preservation of the left valve. I have described the valves separately on account of the possibility that they may belong to different species.

Pecten gardnerce has closer, higher, and more strongly convex ribs than $P$. vaughani and the ribs, in the specimens at hand, extend to the beaks. The secondary sculpture is very different. 
This species closely resembles the figure of $P$. cercadica Maury from Cercado de Mao, Santo Domingo, but seems to be a little less spreading and to have differently shaped ears. In the description of $P$. cercadica, a left valve, no mention is made of any grouping of the growth-lines on the disk.

This species is named in honor of Miss Julia Gardner, whose monographs (unfortunately delayed in publication) on the Miocene Mollusca of Virginia and North Carolina and of the Alum Bluff formation constitute an important contribution to American paleontology.

Locality.-Santiago Cuba, station 3440, Vaughan.

Geologic horizon.

Type.-U. S. Nat. Mus. No. 167113 (right valve).

Figured specimen.-U. S. Nat. Mus. No. 167114 (left valve).

\section{Pecten crocus, new species.}

(Plate 9, Figures $2 a, b$; Plate 11, Figure 9.)

The following is a description of this species:

Shell equivalve, inequilateral, moderately convex; about 22 round ribs, separated by slightly narrower interspaces; surface of the ribs with curved imbricating spines, convex towards the umbones, and with very faint radiating striæ; interspaces with sculpture of fine, close-set, concentric striæ; near the ventral margin a small thread appears in each interspace; submargins depressed, ornamented with small radial threads and fine concentric striæ; ears moderately large, subequal, with radial, nodose riblets.

Alt., $39 \mathrm{~mm}$.; lat., $36 \mathrm{~mm}$.; diam., $14 \mathrm{~mm}$.

Locality.-Roadside, descent to Crocus Bay, Anguilla, station 6893, also 6894 and 6965, Vaughan.

Geologic horizon.-Oligocene.

Type.-U. S. Nat. Mus. No. 167079.

\section{Pecten (Lyropecten) pittieri Dall.}

(Plate 13, Figure 5.)

Pecten (Lyropecten) pittieri Dall, Smithsonian Misc. Coll., vol. 59, No. 2, p. 10, 1912.

The following is the original description of this species:

"Shell large, nearly equivalve, suborbicular, coarsely sculptured; left valve moderately convex, with ten strong rounded ribs, obsolete distally, with shallow rounded interspaces at first narrower, afterwards wider than the ribs; submargins wide, subequal, radially sculptured with coarse, somewhat irregular threads, about ten in number, which when perfect have a fine, concentric, imbricate sculpture; similar radial sculpture covers both valves, the threads coarser and more regular on the right valve; of the major ribs on the left valve, five alternating ones bear on their proximal halves six to ten prominent, thin evenly spaced, vaulted scales, resembling those of $P$. imbricatus Gmelin; similar scales are wanting in the right valve; ears subequal, with about half a dozen radial threads and dense, concentric sculpture; margin of the valve wavy, not sulcate; interior with ten deeply channelled, wide sulci corresponding to the external ribs, the angles of the interspaces emphasized near the valve margin; hinge with a deep subtriangular pit for the resilium, a strong 
anterior ridge and two marked posterior grooves with a ridge between them. Adductor scar large, with a rather ragged margin. Right valve with eleven stronger ribs, each carrying five or six riblets, with two or three similar riblets in the interspaces; the proximal halves of the ribs are slightly undulated but not scaly; ears subequal, rudely imbricate on the dorsal margin and on the four or five radial threads of the anterior ear; ctenolium with about 16 spines, byssal notch narrow, angular; hinge-line grooved reciprocally to that of the left valve. Height 132 ; length of shell 152 ; of hinge-line 82 ; $\max$. diameter omitting spines $46 \mathrm{~mm}$.

"This fine and remarkable species is somewhat intermediate between Lyropecten and Nodipecten, and when young must have the aspect of a Chlamys much like C. imbricatus."

The figured specimen, a right valve from the gorge of Yumuri River, Cuba, is smaller than the type and has higher ribs. It measures $68 \mathrm{~mm}$. in altitude and $72 \mathrm{~mm}$. in latitude. A fragment of a left valve measuring $190 \mathrm{~mm}$. in altitude has been obtained near the mouth of Macambo River, Cuba.

Localities.-Moin Hill, near Port Limon, Costa Rica, niveau a Pittier (type); gorge of Yumuri River below Iglesia Mont Serrato, Matanzas, Cuba, station 3468, Vaughan (figured specimen); Santiago, Cuba, station 5255, Black; near mouth of Macambo River, Cuba, station 7533, Meinzer

Geologic horizon. - Prfiocene, Pliveme.

Type.-U. S. Nat. Mus. No. 214368.

Figured specimen.-U. S. Nat. Mus. No. 167123.

Pecten (Nodipecten) articilosus, new species.

(Plate 7, Figures 7, 8.)

The following is a description of this species:

Shell moderately large, nearly equivalve, slightly oblique, convex; sculpture of 8 to 11 large round ribs with equal concave interspaces, smooth except for close, faint, radial striations which appear distally on both ribs and interspaces of large specimens; ribs on right valve obscurely nodular, ribs on left valve prominently nodular, the undulations affecting the whole of the disk as in $P$. condylomatus; submargins rather wide, compressed in the umbonal region but expanding distally, smooth, except for close faint radial striæ on the distal portion; ears small, subequal, the surface faintly radially threaded.

Alt. of right valve (type) $55 \mathrm{~mm}$., lat. $61 \mathrm{~mm}$., diam. $19 \mathrm{~mm}$; ; alt. of left valve $55 \mathrm{~mm}$., lat. $58 \mathrm{~mm}$. (edge broken), diam. $19 \mathrm{~mm}$.

This species resembles Pecten condylomatus Dall in shape and size, but is more nearly equivalve, has larger and fewer ribs, and lacks the secondary sculpture. It is represented in the collection by 3 right valves and 4 left valves.

Locality.-Disintegrated limestone in a quarry near asylum near Guajay, 15 miles southwest of Havana, Cuba, Barnum Brown, collector.

Geologic horizon.-Oligocene.

Type.-American Museum of Natural History. 
Pecten (Equipecten) decorus, new species.

(Plate 13, Figures $8 a, b$.)

The following is a description of this species:

Shell small, equivalve, moderately convex, slightly oblique, with about 25 ribs, of which one or two are obsolescent; hinge-line three-fifths the entire length of the shell; submargins narrow, with obsolete ribs, merging with the disk; ears large, equal, with 8 or 9 scaly radiating riblets, posterior ears rectangular, byssal notch about one-half the length of the ear; secondary sculpture of scaly riblets, 3 on each rib and 3 in each interspace, scales spaced 3 or 4 per millimeter, concave towards the umbones, erect or inclined toward the margin.

Alt. $30 \mathrm{~mm}$., lat. $29 \mathrm{~mm}$., diameter of united valves $15 \mathrm{~mm}$.

The type, a specimen with united valves, is unique.

Locality.-Disintegrated limestone in quarry near the asylum near Guajay, 15 miles southwest of Havana, Cuba, Barnum Brown, collector.

Geologic horizon.-Oligocene.

Type.-American Museum of Natural History.

Pecten (\&quipecten) oxygonum Sowerby?

(Plate 8, Figure 5.)

\begin{abstract}
Pecten oxygonum Sowerby., Quart. Journ. Geol. Soc. London, vol. 6, p. 52, 1849.
Pecten exasperatus Guppy, Quart. Journ. Geol. Soc. London, vol. 22, p. 294, 1866.

Pecten angusticostatus Gabb, Trans. Amer. Phil. Soc., new ser., vol. 15, p. 256, 1873.

Pecten (\&quipecten) oxygonum Dall, Trans. Wagner Inst., vol. 3, p. 713, 1898.

Pecten (AEquipecten) oxygonum Brown, Proc. Acad. Nat. Sci. Phila., p. 601, 1913.
\end{abstract}

The following is the original description of this species:

"Testa suborbicularis, subobliqua, tumida, costellis radiantibus 19, superne acutangulis, interstitiisque aequalibus lineis incrementi concinne decussatis; auribus inaequalibus, laevibus, radiatim costellatis, costellis tenuissimis."

The following is a new description of this species:

Shell suborbicular, slightly convex, with 19 or more low, rounded, radiating ribs, separated by equal, shallow interspaces; secondary sculpture of numerous narrow, radiating threads. Length, $35 \mathrm{~mm}$.

We possess of this species only two fragments which it would be unsafe to identify without material for comparison; there can be little doubt, however, that they represent the species reported by A. P. Brown from the same locality and identified by him from specimens from Santo Domingo, where the type of Pecten oxygonum was collected.

Locality.-Lower bed at Hodge's Bluff, Antigua, station 6862, Vaughan; Santo Domingo, Bowden.

Geologic horizon.-Oligocene.

Type.-British Museum?

Figured specimen:-U. S. Nat. Mus. No. 167065. 
Pecten species, cf. Pecten oxygonum Sowerby.

(Plate 10, Figure 7.)

?Pecten oxygonum optimum Brown, Proc. Acad. Nat. Sci. Phila., p. 601, 1913.

The following is a description of this species:

Shell with many low, nearly obsolete ribs, each of which consists of 3 or more radial threads with concentric, scabrous growth-lines.

This is probably the species referred by Professor Brown to $P$. oxygonum optimum Brown and Pilsbry. The single specimen in the National Museum has very much lower ribs than are shown in the figure of the Panamanian form.

Locality.-Willoughby Bay, Antigua, station 6881, Vaughan.

Geological horizon.- Oligocene.

Figured specimen.-U. S. Nat. Mus. No. 167066.

Pecten (Equipecten) perplexus, new species.

(Plate 8, Figures 8, 9, 10.)

The following is a description of this species:

Shell equivalve, equilateral, with 19 or 20 simple ribs with narrower interspaces; minute sculpture of $\mathrm{V}$-shaped spines arranged in longitudinal rows on ribs and interspaces, those in the interspaces concave above and ventrally inclined; submargins narrow, smooth or with a few radial threads; Camptonectes striation present; ears large, subequal, with fine radial ribs, coarser and nodose on right anterior ear; byssal notch one-half the length of the ear; inner margin crenulated in accordance with the external ribbing.

Alt., $28.5 \mathrm{~mm}$.; lat., $26.5 \mathrm{~mm}$.

The spines are very easily eroded, leaving the shell either perfectly smooth or with a single row of minute scales on the sides of the ribs.

Localities.-Crocus Bay, Anguilla, stations 6893, 6894, 6966, 6967, 6971, Vaughan.

Geologic horizon.-Oligocene.

Types.-U. S. Nat. Mus. No. 167076.

\section{Pecten (Æquipecten) thetidis Sowerby.}

(Plate 11, Figures 4, 5, 6.)

Pecten thetidis Sowerby, Quart. Jour. Geol. Soc. London, vol. 6, p. 52, 1850. (Date of imprint, 1849.)

Pecten thetidis Gabb, Jour. Acad. Nat. Sci. Phila., 2d ser., vol. 8, p. 346, plate 45, figs. 23, $23 a, b, 1881$.

Pecten thetidis Gabb, Trans. Amer. Phil. Soc., new ser., vol. 15, p. 256, 1881.

Pecten (Equipecten) thetidis Brown, Proc. Acad. Nat. Sci. Phila., p. 602, 1913.

Pecten (Equipecten) thetidis Dall, Trans. Wagner Inst. Sci., vol. 3, p. 714, 1898.

Pecten (Æquipecten) thetidis Maury, Bull. Amer. Pal., vol. 5, p. 349, plate 60, fig. 6, 1917.

The following is the original description of this species:

"Testa orbicularis, tumida, radiatim costata, costarum marginibus quadratis, ad utrumque latus squamuliferis, squamulis minutissimis, interstitiis rugulosis; auribus inæqualibus, radiatim costatis, costellis squamulosis." 
The following is a new description of this species:

Shell orbicular, tumid, with 19 radiating ribs, simple to about $10 \mathrm{~mm}$. from the beak, but each with two lateral riblets on the mature part of the shell; spaces between the ribs deep, concave, a little narrower than the ribs, set with riblets near the periphery; surface covered with concentric imbrications which are produced into blunt spines on top of the ribs and riblets; submargins with numerous radiating riblets; ears rather large, with radiating threads and concentric imbrications.

Alt., $21 \mathrm{~mm}$.; lat., $23 \mathrm{~mm}$; diam., about $5 \mathrm{~mm}$.

Localities.-Crocus Bay, Anguilla, stations 6965 and 6967, Vaughan; Santiago, Cuba, station 5255, Black; Santo Domingo, Bowden.

Geologic horizon.-Oligocene, Priveme.

Type.-British Museum, from Santo Domingo.

Figured specimens.-U. S. Nat. Mus. Nos. 167069, 167070, 167071.

Pecten (Equipecten) jacobianus, new species.

(Plate 11, Figures $7 a, b, 8$.)

The following is a description of this species:

Shell equivalve, slightly oblique, moderately convex, with about 16 low, broad, radiating medial ribs and several additional obsolete distal ribs; additional radial sculpture of raised threads, usually one on summit and one or more on each side of every rib and one or two in the interspaces, increasing in number by interpolation towards the periphery; concentric sculpture of low, wavy lamellæ, crossing ribs, threads, and interspaces; Camptonectes striation present; posterior ears oblique, with faint radiating threads crossed by fine lamellæ; anterior ears the larger, with coarser threads; byssal notch about one-half the length of the ear; ctenolium present; inner margin grooved in accordance with the external ribbing, but grooves do not extend over the medial portion of the disk.

Alt., $29 \mathrm{~mm}$.; lat., $27.5 \mathrm{~mm}$.; diameter, $9 \mathrm{~mm}$.

Localities.-Santiago, Cuba, stations 3436, 3440 (type), 3443, 3447, Vaughan.

Geologic horizon.-Oitigocene.

Type.-U. S. Nat. Mus. No. 167115.

Pecten (Plagioctenium) crucianus, new species.

(Plate 10, Figures 8, $9 a, b$. )

The following is a description of this species:

Shell suborbicular, slightly oblique, moderately convex, with nearly equal valves and 20 to 22 convex ribs with equal interspaces, each containing 1 riblet; near the periphery 1 riblet is developed on the summit of each rib; submargins faintly ribbed; entire disk covered with minute, close, concentric, raised lamellæ, fused on the summits of the riblets into evenly spaced, raised, transversely elongate nodes; anterior ears the larger; right anterior ear with about 5 strong riblets, other ears with many fine riblets; posterior ears oblique; byssal notch deep; internal surface channeled in harmony with the external ribbing.

Alt., $35.4 \mathrm{~mm}$.; lat., $35.4 \mathrm{~mm}$.; diam. of left valve, $7.4 \mathrm{~mm}$. 
Localities.-La Cruz and Santiago, Cuba, stations 3439, 3440 (type), 3441, Vaughan.

Geologic horizon.-Oligocene.

Type.-U. S. Nat. Mus. No. 167108.

Pecten species, cf. Pecten crucianus Cooke.

Fragments differing slightly in sculpture from $P$. crucianus, but apparently closely related to it, were found at Crocus Bay, Anguilla. These fragments show no fusion of the concentric lamellæ - a characteristic of $P$. crucianus.

Localities.-Crocus Bay, Anguilla, stations 6893 and 6967.

Geologic horizon.-Oligocene.

\section{Pecten (Plagioctenium) gabbi Dall. \\ (Plate 12, Figure 8.)}

Pecten (Plagioctenium) gabbi Dall, Trans. Wagner Inst., vol. 3, pt. 4, p. 717, plate 29, fig. 3, 1898.

Pecten (Plagioctenium) gabbi Brown, Proc. Acad. Nat. Sci., Philadelphia, p. 602, 1913.

The following is the original description of this species:

"Shell broad, compressed, oblique, inequilateral, with nearly equal valves and about nineteen concentrically scabrous, longitudinally striated ribs, with narrow interspaces, each filled with one imbricated riblet.

"Alt. 48, lat. 52, diam. $13 \mathrm{~mm}$."

The type of this species is said to have come from Antigua.

A specimen from Anguilla resembles the type in shape, size, and number of ribs, but has lost the outer layers of shell carrying the secondary sculpture.

Localities.-Antigua, Spencer; Crocus Bay, Anguilla (station 6894), Vaughan. Professor Brown reports this species from Willoughby Bay, Antigua.

Geologic horizon.-Oligocene.

Type.-U. S. Nat. Mus. No. 107753.

Figured specimen.-U. S. Nat. Mus. No. 167101.

Pecten (Patinopecten) duplex, new species.

(Plate 11, Figures $10 a, b$.)

The following is a description of this species:

Shell equilateral, large; right valve gently convex, left valve nearly flat; ribs 20 , each with a shallow groove on top; ears large, subequal; surface sculpture of close-set, concentric, raised lines nearly straight in the interspaces but convex towards the beaks on the ribs.

Alt., $52 \mathrm{~mm}$. ; diam., $11 \mathrm{~mm}$.

This species, although represented by a single broken specimen, should be easily recognized. Its closest relative seems to be $P$. healeyi Arnold from the Pliocene of California, which is a much larger species and lacks the grooves on the ribs of the flat valve. 
Locality.-Long Island, Antigua, station 6869, Vaughan.

Geologic horizon.-Oligocene.

Type-U. S. Nat. Mus. No. 167107.

Pecten nodosissimus, new species.

(Plate 7, Figure 3.)

The following is a description of this species:

Right valve nearly flat, equilateral, with 15 ribs equal in width to the interspaces. Each rib has 3 lines of bead-like nodes, 1 median line and 2 lateral lines. Submargins strongly convex, apparently smooth and sharply differentiated from the ears. The ears are broken, but appear to have been rather large; the left posterior ear had several faint radiating threads.

Altitude, $25 \mathrm{~mm}$.

The sculpture of this shell is so peculiar that I have ventured to describe it in spite of its fragmentary condition.

Locality.-Willoughby Bay, Antigua, station 6881, Vaughan.

Geologic horizon.-Oligocene.

Type.-U. S. Nat. Mus. No. 167131.

Pecten perlineatus, new species.

(Plate 10, Figure 5.)

The following is a description of this species:

Left (?) valve flat, equilateral, with 16 round ribs with wider shallow, concave interspaces; radial sculpture of fine, close-set, raised lines covering both ribs and interspaces; submargins convex; ears much depressed below the plane of the disk.

Alt., $35 \mathrm{~mm}$.; lat., about the same.

Locality.-Willoughby Bay, Antigua, station 6881, Vaughan.

Geologic horizon.-Oligocene.

Type.-U. S. Nat. Mus. No. 167130.

\section{Pecten nugenti Brown?}

(Plate 10, Figure 6.)

Pecten nugenti Brown, Proc. Acad. Nat. Sci. Phila., p. 614, plate 19, figs. 2, 5, 6, 1913.

The following is the original description of this species:

"Shell inequivalve, oval in outline, with 17 distinct rounded radial ribs (and probably 2 additional less distinct ones) separated by narrower interspaces, the whole exterior surface covered by concentric growth lines which are raised and produce a nearly microscopic sculpture extending equally over ribs and interspaces. Internally smooth, except near the margin, where raised ribs are seen, occupying the intervals between the raised external ribs. On the flatter valve, externally the raised ribs are equal in width with the intervals between them, and the concentric sculpture, while extending over ribs and interspaces, is stronger in the intervals between the ribs. Ears moderate, apparently not ribbed. The specimens vary considerably in size; the one figured, a small specimen, measures: Length $41 \mathrm{~mm}$. by height $36 \mathrm{~mm}$. Others were much larger, attaining a length of $55 \mathrm{~mm}$. or more." 
One poorly preserved specimen is doubtfully referred to $P$. nugenti. Locality.-Hodge's Bay, Antigua, station 6862, Vaughan.

Geologic horizon.-Oligocene.

Cotypes.-Phila. Acad., No. 1656.

Figured specimen.-U. S. Nat. Mus. No. 167067.

Pecten species.

(Plate 13, Figure 4.)

The Vaughan collection contains a fragment of a Pecten, probably new, which is very convex and when entire had probably about 25 round ribs with equal interspaces. It has a concentric sculpture of close raised lines. The margin is fluted within in accordance with the external ribbing and set with paired raised lines corresponding to the interspaces. These raised lines end abruptly at a distance of about 2 $\mathrm{mm}$. from the margin, but are continued on the inner layers of the shell.

Locality. - Willoughby Bay, Antigua, station 6881, Vaughan.

Geologic horizon.-Oligocene.

Figured specimen.-U. S. Nat. Mus. No. 167132.

Pecten (Amusium) lyonii (Gabb.)

(Plate 13, Figures $1 a, b, 2$.)

Pecten mortoni Guppy, Geol. Mag., Dec. 2, vol. 1, p. 443, 1874. (Not of Ravenel.)

Pleuronectia lyonii Gabb., Jour. Acad. Nat. Sci. Phila., 2d ser., vol. 8, p. 347, plate 45, figs. $25 a, b, 1881$.

Amusium lyoni Dall, Trans. Wagner Inst., vol. 3, pt. 4, p. 719, 1898.

The following is a description of this species:

Shell orbicular, thin, compressed; nepionic shell with about 24 small rounded ribs which disappear on the adult shell; ears large, equal; right valve a little more inflated than the left, evenly convex, smooth; left valve nearly flat, with a broad, shallow, radial depression from beak to margin at the posterior quarter and a very faint corresponding depression at the anterior quarter; left valve with concentric sculpture of fine, impressed lines, between which the shell is sometimes slightly convex; hinge-line nearly straight; submargins very narrow; interior of the shell with low, equidistant ribs; paired peripherally.

Alt., $54 \mathrm{~mm}$.; lat., $56 \mathrm{~mm}$.; diam., $13.5 \mathrm{~mm}$.

This shell is very like Amusium precursor Dall, from the Chipola Oligocene, but that species lacks the nepionic ribbing, which appears to be a constant feature of the Anguillan form. A. mortoni Ravanel is quite distinct, being proportionately higher and having a smooth nepionic shell.

This species is referred to A. lyonii on the authority of Dr. W. H. Dall, who has identified a right valve in the Guppy collection with Gabb's shell. It is possible, however, that comparison of the left valve, which possesses more identifiable characteristics than the right, will show this species to be distinct from the Costa Rican form. A left valve from $70 \mathrm{~km}$. west of the terminal of the Tehuantepec Railway, 
identified by Dr. Dall as A. lyonii, is distinct from the Anguillan species, having on the nepionic shell distinct flattened ribs with shallow, channeled interspaces crossed by concentric, evenly spaced, not crowded, elevated lines. If this is the true A. lyonii, the Anguillan fossil must receive a different name.

Localities.-Crocus Bay, Anguilla, stations 6893, 6966, 6967, Vaughan; Anguilla, Guppy; Sapote, Costa Rica, Gabb.

Geologic horizon.-Oligocene.

Type.-Philadelphia Academy.

Figured specimens.-U. S. Nat. Mus. No. 167136.

Pecten (Amusium) antiguensis Brown.

(Plate 13, Figures 6, 7.)

Pecten (Amusium) antiguensis Brown, Proc. Acad. Nat. Sci. Phila., p. 613, plate 18, figs. 1, 2, $3,5,1913$.

The following is the original description of this species:

"Inequivalve, shell orbicular, rather thin, convex; the surface covered with a fine concentric sculpture, following the growth-lines; with about 13 radial ribs running from the beaks, where they are very pronounced, and, in one valve, apparently disappearing towards the margin, but in the other valve continued as undulations of the shell to the margin. The interior of the shell has radial ribs extending to the margin, where the adjacent pairs of ribs contract and are then seen to be paired, but otherwise seeming to be equally spread as in P. (Amusium) lyonii Gabb, from which this species differs in having a strong concentric sculpture (wanting in P. lyonii), and also in the external radial ribbing being continued for a greater distance from the beak than in Gabb's species. The species is also related to $P$. sol B. and P., but this latter has shorter radial external ribs and the internal ribs are paired. The ears are separated from the rest of the valve by a depression, as in the case of $P$. sol. Length and height about equal- $70-75 \mathrm{~mm}$.

"Hodge's Bay and Wetherill's Bay in the Antigua limestone, with Orbitoides, etc., Oligocene."

The Vaughan collection contains several well-preserved fragments of this species.

Locality. - Station 6862, lower bed at Hodge's Bluff, Antigua, Vaughan.

Geologic horizon.-Oligocene.

Types.-Philadelphia Academy, No. 1648.

Figured speeimen.-U. S. Nat. Mus. No. 167139.

Pecten (Hinnites) aratus, new species.

(Plate 12, Figures $2 a, b, 3,4,5,6,7$.)

The following is a description of this species:

Shell large, convex, equilateral, flabelliform or suborbicular, inequivalve; ribs 38 , close-set, rounded, in mature specimens flattened distally, crossed by fine, concentric, imbricate lamellæ with spinose projections on the sides of the ribs; interior narrowly channeled in harmony with the external ribbing; mar- 
gin fluted within; posterior ears oblique, with imbricating growth-lines and one simple radiating rib adjacent to the abruptly sloping submargins.

Alt. about $46 \mathrm{~mm}$.; lat. , about $45 \mathrm{~mm}$.; alt. of largest specimen about $70 \mathrm{~mm}$.

This species, which is curiously intermediate between Pecten and Spondylus, probably belongs to the subgenus Hinnites. The sculpture and ears are distinctly pectiniform, but the discrepancy in the shape and size of the valves is like that of Spondylus.

Localities.-Northwest of St. Jean Bay, point between Anse Écaille and Anse Lézard, and point between Colombier Point and bay next to St. Jean Bay, St. Bartholomew (stations 6897, 6897a, b, 6905, 6924), Vaughan.

Geologic horizon.-Eocene. Near top of the conglomerate series and beneath the main limestone bed.

Type.-U. S. Nat. Mus. No. 167124.

\section{Spondylus bostrychites Guppy.}

\section{(Plate 11, Figures $11 a, b$.)}

Spondylus bifrons Sowerby, Quart. Jour. Geol. Soc. London, vol. 6, p. 53, 1850 (date of imprint, 1849). Not of Goldfuss, 1835.

Spondylus bostrychites Guppy, Proc. Sci. Asso. Trinidad, p. 176, 1867.

Spondylus bostrychites Gabb, Trans. Amer. Phil. Soc., vol. 15, n. s., p. 257, 1881.

Spondylus bostrychites Dall, Trans. Wagner Inst. Sci.., vol 3, pt. 4, p. 758, 1898.

Spondylus bostrychites Dall, U. S. Nat. Mus. Bull. 90, p, 124, plate 19, fig. 4, 1915.

Spondylus bostrychites Maury, Bull. Amer. Pal., vol. 5, p. 354, plate 58, fig. 4, 1917.

The following is Sowerby's description of this species, 1849:

"Testa subregularis, rotundata, ventricosa, margine latiusculo, valide denticulato; extus radiatim costata, costis 5 ad 6 spiniferis; area cardinali alterius valvæ angustissima, alterius latiori."

The shell is orbicular, pectiniform, nearly equivalve, with very small submargins. The spinose ribs are separated by numerous finer, spineless ribs bearing minute, close-set ( 2 or 3 per $\mathrm{mm}$.), erect scales. The short submargins and more rotund form distinguish $S$. bostrychites from $S$. dumosus.

Guppy's collection, now in the National Museum, contains 4 specimens labeled types -2 specimens from Jamaica and 2 from Anguilla. The Jamaican forms have coarser intermediate ribs than those from Anguilla and perhaps other differences might be detected if a larger suite of specimens were available for comparison. I have not seen Guppy's description and consequently do not know which form is the true $S$. bostrychites. Sowerby's type is from Santo Domingo.

Localities.-Crocus Bay, Anguilla, stations 6894, 6965, 6967; Friar's Hill, Long Island, and Willoughby Bay, Antigua, stations 6856, 6869, 6881, Vaughan; also at Pontou, Santo Domingo; Bowden, Jamaica; Tampa, Florida.

Geologic horizon.-Oligocene.

Types.-U. S. Nat. Mus. Nos. 115522 or 115523.

Figured specimen.-U. S. Nat. Mus. No. 167140. 
Spondylus species.

In the Vaughan collection are numerous specimens of a species of Spondylus which I have been unable to identify with any described species. It appears to be more rotund than $S$. dumosus and $S$. scotti, but less so than $S$. bostrychites. The ribs are uniform or slightly alternating in size and set with the spines customary to the genus. The finer sculpture, which is of much more diagnostic value than the coarser, is entirely obliterated in the specimens at hand.

Localities.-Northwest side of St. Jean Bay and point between Anse Écaille and Anse Lézard, St. Bartholomew, stations 6897, $6897 a, b$, 6924, Vaughan.

Geologic horizon.--Eocene, near top of the conglomerate series and beneath the main limestone bed.

\section{Plicatula densata Conrad.}

(Plate 11, Figures $12 a, b$.)

Plicatula densata Conrad, Proc. Acad. Nat. Sci. Phila., vol. 1, p. 311, 1843.

Plicatula densata Conrad, Foss. of the Medial Tertiary, p. 75, plate 43, fig. 6, 1845.

Spondylus inornatus Whitfield, Miocene Pal. N. J., p. 34, plate 5, figs. 1, 2, 1895.

Plicatula densata Dall, Trans. Wagner Inst., vol. 3, pt. 2, p. 763 (ex parte), 1898.

Plicatula densata Dall, U. S. Nat. Mus. Bull. 90, p. 125 (ex parte), 1915.

The following is Conrad's description of this species, 1845:

"Ovate, thick, profoundly and irregularly plicated; inferior valve ventricose; ribs acute, with arched spiniform scales; cardinal teeth large, curved, laterally striated, crenulated on the margins; larger cardinal tooth in each valve slightly bifid, broad; muscular impressions prominent.

"Loc. Cumberland Co., New Jersey.

"The valves have about 10 folds, and the lower valve closely resembles a variety of Ostrea virginiana." * ws.

The Cuban form seems indistinguishable from the continental.

Localities.-Santiago, Cuba, stations 3436, 3447, Vaughan; also at Tampa, Chipola, and Oak Grove, Florida, and in the Miocene of New Jersey.

Type.-Philadelphia Academy?

Figured specimen.-U. S. Nat. Mus. No. 167150.

Modiolus (Botula) cinnamomeus (Lamarck).

(Plate 14, Figures 4, 5.)

Mytilus cinnamominus, etc., Chem., Conch. Cab., vol. 8, p. 152, plate 82, fig. 731, 1785.

Modiola cinnamomea Lam., Anim. sans Vert., vol. 6, p. 114, 1819; ed. Desh., vol. 7, p. 25, 1835. Modiolus (Botula) cinnamomeus Dall, Trans. Wagner Inst., vol. 3, p. 797, 1898.

Modiolus (Botula) cinnamomeus Dall, U. S. Nat. Mus., Bull. 90, p. 128, 1915.

The following is Lamarck's description of this species:

"M. testa subcylindrica, ventricosa, arcuata, utraque extremitate retusa; natibus subprominulis.

"Habite les mers de l'Isle de France. Coquille de couleur marron, ayant l'aspect d'un gland arqué; à valves très concave. Longueur, $37 \mathrm{~mm}$." 
The Cuban specimens are well grown, being considerably larger than most of the fossils from Florida, but agreeing well with mature living shells. They are preserved only as casts.

Localities.-Near Santiago, Cuba, stations 3192, 5255, Wilcox, Black; Tampa, Chipola, Caloosahatchee River, Florida; Trinidad.

Geologic horizon.-Oligocene.

Figured specimens.-U. S. Nat. Mus. No. 167153.

\section{Lithophaga nigra (d'Orbigny).}

(Plate 14, Figure 6.)

Lithodomus niger d'Orbigny, de la Sagra's Hist. de Cuba (Spanish edition), pt. 2, vol. 5, plate 28 , figs. $10,11,1845$.

Lithodomus niger d'Orbigny, idem (French edition), vol. 2, p. 331, plate 28, figs. 10, 11, 1847. Lithophaga nigra Dall, Trans. Wagner Inst., vol. 3, pt. 4, p. 799, 1898.

Lithophaga nigra Dall, U. S. Nat. Mus. Bull. 90, p. 129, 1915.

Lithophaga nigra Maury, Bull, Amer. Pal., vol. 5, p. 358, 1918.

The following is the original description of this species:

"Liтноромus testa oblongo-elongata, recta, epidermide nigrescente; latere buccale angustiore, obtuso; latere anali elongatissimo subterque rotundato, regione ligamenti subcompresso, regione palleali transversim striato; natibus mediocribus, contortis intus; latere anali incrassato, albido."

This species may readily be recognized by the fact that its striæ cease abruptly at an imaginary line drawn from the beak to a point near the posterior extremity of the ventral margin, leaving the dorsal portion of the shell smooth.

Localities.-Friar's Hill, Antigua; La Cruz and Santiago, Cuba, stations $6856,3441,5255$, Vaughan, Black; Tampa "silex" bed; living in the Antillean region and adjacent areas.

Geologic horizon. - Oligocene, Mrioeene.

Type.-(?)

Figured specimen.-U. S. Nat. Mus. No. 167156.

Lithophaga species.

The Vaughan collection contains one specimen of this genus which retains traces of ribbing on the dorsal portion of the valve. As the outer layers of the shell are absent from the remainder of the valve, the specific determination must await additional collections. The species may prove to be $L$. antillarum (d'Orbigny).

Locality. - One-half mile north of McKinnon's Mill, Antigua, station 6888, Vaughan.

Geologic horizon.-Oligocene.

Teredo species.

A large species of Teredo was abundant in the Oligocene of Cuba. The valves have never been found, but tubes of all sizes up to $38 \mathrm{~mm}$. in external diameter are common. The tubes are divided towards the smaller ends by a partition into two unequal chambers in the manner shown in the figure of Kuphus incrassatus Gabb. ${ }^{1}$ 
Localities.-Santiago, Willcox, Vaughan; Consolacion del Sur, the Alcalde; and Vento, Cuba, Wren, Black, stations 3192, 3435, 3474, 4290,5255 .

Geologic horizon.-Oligocene, Srivene.

Specimens.-U. S. Nat. Mus.

\section{Panope species.}

An internal cast of a large Panope was collected by T. H. Wren at Vento, Cuba. The dimensions are: Alt., $68 \mathrm{~mm}$.; long., $115 \mathrm{~mm}$.; diam., $46 \mathrm{~mm}$.

Locality.-Vento, near Havana, Cuba, station 4290, Wren.

Geologic horizon.- Oligocene.

Specimen.-U. S. Nat. Mus. No. 167164.

\section{Solemya sulcifera, new species.}

(Plate 14, Figure 3.)

The following is a description of this species:

Shell elongate-elliptical; beaks situated near the posterior quarter; umbonal region moderately inflated; a broad, shallow depression extends from the beaks to the middle of the ventral margin; surface ornamented with about 15 broad, shallow, radiating, irregularly spaced grooves separated by slightly broader flat ribs.

Length of fragmentary specimen, about $67 \mathrm{~mm}$; altitude, about $31 \mathrm{~mm}$.

Locality.-Angela Elmira asphalt mine, near Bejucal, Cuba, station 3652 , Wiebusch.

Geologic horizon.-Oligocene?

Type--U. S. Nat. Mus. No. 167165.

\section{Tellina species.}

The cast of a left valve which closely resembles the living Tellina interrupta Wood.

Alt., $29 \mathrm{~mm}$.; long., $55 \mathrm{~mm}$.

Locality.-Near Santiago, Cuba, station 5255, Black.

Geologic horizon.-Oligocene.

Specimen.-U. S. Nat. Mus. No. 167166.

Semele? species.

(Plate 14, Figure 1.)

From Antigua come fragments of two left valves, each of which has lost the posterior end. The shell is striated in accordance with the lines of growth, but is otherwise smooth. The hinge of one specimen is partly exposed, showing two cardinal teeth, but not sufficiently to establish positively the generic position.

Locality. -Willoughby Bay, Antigua, station 6881, Vaughan.

Geologic horizon.-Oligocene.

Figured specimen.-U. S. Nat. Mus. No. 167167. 


\section{Metis trinitaria Dall.}

(Plate 14, Figures $2 a, b$.)

Tellina biplicata Guppy, Proc. Geol. Soc., vol. 22, p. 588, 1866. (Not of Conrad.) Tellina biplicata Guppy, Proc. Sci. Assoc Trinidad, p. 161, 1867.

Tellina sagrae Guppy, Quart. Jour. Géol. Soc. London, p. 530, 1876.

Tellina sagrce Dall and Guppy, Proc. U. S. Nat. Mus., 19, p. 329, 1896. (Not of d'Orbigny.)

Metris trinitaria Dall, Trans. Wag. Inst., vol. 3, pt. 5, p. 1041, plate 46, fig. 24, 1900.

The following is the original description of this species:

"Shell anteriorly elongated and dorso-ventrally attenuated, the anterior dorsal slope rapid, the anterior end rounded; the disk mesially constricted, the posterior end short, high, blunt, strongly folded; beaks high, surface sculptured with numerous small, sharp, slightly elevated concentric lamellæ, which are closer towards the ends of the shell; interior with the pallial sinus larger and higher in the left valve, about half confluent below, deep and rounded in front. Lon. 52, alt. 41 , diam. $19 \mathrm{~mm}$., but reaching twice this size.

"The peculiar anterior elongation and arcuate form of this species distinguish it clearly from the other American species. Guppy erroneously identified it with a Miocene and also with a Pleistocene species, from both of which comparison shows it perfectly distinct." (Dall, 1900.)

Localities.-Santiago, La Cruz, and Vento, Cuba, stations 3192, 3441, 3439, 4290, and 5255, Willcox, Vaughan, Black; also Trinidad; Crocus Bay, Anguilla, stations 6894, 6966, Vaughan.

Geologic horizon.-Oligocene, Oriweme.

Types.-U. S. Nat. Mus. No. 115660.

Figured specimen.-U. S. Nat. Mus. No. 167171.

\section{Cardium species.}

The genus Cardium is represented in the Anguillan fauna by casts which I have been unable to identify with any described species.

Locality.-Crocus Bay and Sandy Hill, Anguilla, stations 6894, 6963, 6967, Vaughan; also (probably different species) Calabazar, Cuba, station 4291, Wren.

Geologic horizon.-Oligocene.

Lucina species.

Large globose lucinas appear to have been rather abundant in the Tertiary seas, but are preserved chiefly as casts which exhibit few characters suitable for specific discrimination. Some of the localities are given below.

Localities.-Quarries west of Smithfield Mill, Friedericksted, St. Croix, station 6937; dimensions, alt., $100 \mathrm{~mm}$.; long., $120 \mathrm{~mm}$; d diam., 86 mm.; Vaughan. Crocus Bay, Anguilla, stations 6894, 6966; dimensions, alt., $75 \mathrm{~mm}$.; long., $84 \mathrm{~mm}$.; diam., $60 \mathrm{~mm}$.; Vaughan. Calabazar, Cuba, station 4291; dimensions, alt., $103 \mathrm{~mm}$.; long., $110 \mathrm{~mm}$.; diam., 70 mm.; Wren. Also Vento, "E. C. A.," Fort Cabañas, Cuba, stations 4290, 4292, 3465; Wren, Vaughan.

Geologic horizon.-Oligocene. 
Myrtæa(?) asphaltica, new species.

(Plate 14, Figures $7 a, b, 8,9 a-c$.)

The following is a description of this species:

Shell large, robust, transversely elliptical, lucinoid; anterior and ventral margins rounded, posterior margin truncated; beaks full, situated a little in front of the middle; surface sculpture of rough, crowded, concentric growthlines and, on the umbones, equidistant, concentric ridges, becoming obsolete distally; dorsal areas obsolete; inner margins entire; anterior adductor scar lucinoid but rather short; lunule broadly lanceolate; escutcheon linear or narrowly lanceolate, depressed, bordered by a sharply angular keel; hinge with 1 right and 2 left cardinal teeth, 1 right and 2 left anterior laterals, and the same number of posterior laterals; left laterals feeble; ligament external but deeply depressed, preserved in the types.

Alt. of a medium-sized specimen, $40 \mathrm{~mm}$.; length, $49 \mathrm{~mm}$; diam., $25 \mathrm{~mm}$. A larger specimen measures $57 \mathrm{~mm}$. in altitude and $39 \mathrm{~mm}$. in diameter.

This exceedingly interesting species, undoubtedly a member of the family Lucinidæ, is closely related to Myrtæa, but is very much larger than any hitherto described American species of that genus, and has weaker sculpture than is customary. It is separated at once from Lucina by its dentition and escutcheon; from Loripes by the escutcheon, external ligament, and dentition; and from the greater number of Phacoides by the absence of dorsal areas.

Locality.-Angela Elmira asphalt mine, near Bejucal, Cuba, stations 3652,5312 , Wiebusch.

Geologic horizon.-Oligocene?

Type.-U. S. Nat. Mus. No. 167186.

Phacoides (Miltha) aff. Phacoides hillsboroënsis (Heilprin).

(Plate 15, Figures $3 a, b$.)

This species, which is known only from casts of the interior, resembles rather closely Miltha hillsboroënsis, from which it differs in its more depressed posterior dorsal areas.

Alt., $62 \mathrm{~mm}$.; lat., $62 \mathrm{~mm}$; diam., $26 \mathrm{~mm}$.

Localities.-Near Santiago, Cuba, stations 3192 and 5255, Willcox, Black.

Geologic horizon.-Ori Oligocene.

Figured specimen.-U. S. Nat. Mus. No. 167189.

Phacoides (Here) species.

(Plate 15, Figure 2.)

The following is a partial description of this species:

Right valve resembling $P$. wacissanus Dall but with straighter dorsal margin and more deeply impressed sulcus, which extends with undiminished depth to the beak; left valve with shallower sulcus.

The specimens probably represent an undescribed species, but are too fragmentary to furnish a complete diagnosis.

Locality.-Crocus Bay, Anguilla, stations 6965, 6894, Vaughan.

Geologic horizon.-Oligocene.

Figured specimen.-U. S. Nat. Mus. No. 167190. 


\section{Antigona cæsarina var. anguillana, new variety.}

(Plate 16, Figures $4 a, b$.)

Cytherea caesarina Dall, Trans. Wagner Inst. Sci., vol. 3, pt. 6, p. 1275, plate 53, fig. 5, 1903. Antigona (aff.) casarina Dall, Proc. U. S. Nat. Mus., vol. 51, No. 2162, p. 500, 1916.

The following is a description of this variety.

Shell orbicular, convex; sculpture of numerous low, flat, narrow, radial riblets, separated by slightly wider interspaces, and of elevated, reflexed, crenulated, concentric lamellæ; lunule broad, cordate, extended anteriorly; escutcheon long, wider in the right valve, defined on each valve by a deep sulcus.

Length of the specimen figured (broken at the posterior end), $53 \mathrm{~mm}$.; height, $52 \mathrm{~mm}$.; diameter of joined valves, $30.5 \mathrm{~mm}$.

The radial riblets are more prominent in the variety anguillana than in the typical A. coesarina and the lunule is more extended in front. Perfect specimens might show other distinguishing characters.

Antigona anguillana resembles $A$. tarquinia (Dall) from the Tampa "silex" bed, from which it may readily be distinguished by its more orbicular shape, greater inflation of the umbones, closer concentric lamellæ, and much broader, cordate lunule. Its sculpture, as well as can be determined from the specimens at hand, is like that of the Recent and Pleistocene $A$. listeri (Gray), from which it differs in the greater inflation of the posterior dorsal slopes, which, in the latter species, are flat or even slightly concave. A very closely related, perhaps identical, form from the base of the Chattahoochee formation near Bainbridge, Georgia, has been listed as A. (aff.) coesarina by Dall.

Localities. - Crocus Bay, Anguilla, station 6893; Blizzard Mill, Antigua, station 6874; Vaughan. A fragment with similar sculpture is from the chert interbedded with tuffs at St. Johns, Antigua, station 6855. The type of $A$. cosarina is from the Chipola Miocene at station 2212, Ten Mile Creek, Calhoun County, Florida.

Geologic horizon.-Oligocene.

Type of A. ccesarina Dall.-U. S. Nat. Mus. No. 114754.

Type of variety anguillana Cooke.-U. S. Nat. Mus. No. 167192.

\section{Chione spenceri, new species.}

(Plate 15, Figures $1 a, b$.)

The following is a description of this species:

Shell ovate, moderately convex, with low, prosogyrate beaks and a sharply defined, lozenge-shaped lunule with imbricating growth-lamellæ; escutcheon lanceolate, flat or slightly concave, and with fine growth-lines; radial sculpture of minute, close, low, rounded ridges becoming obsolete at the anterior and posterior ends; concentric sculpture of erect, evenly spaced lamellæ, 24 on the type specimen, smooth on the dorsal surface and on the upper part of the ventral surface, but with a row of beads, contiguous to the radial ribbing, at the base of the ventral surface.

Length, $26 \mathrm{~mm}$; height, $23 \mathrm{~mm}$.; diameter of joined valves, $15.5 \mathrm{~mm}$.

Localities.-Antigua, Spencer (type); Willoughby Bay, Antigua, station 6881 ; Vaughan.

Geologic horizon.-Oligocene.

Type.-U. S. Nat. Mus. No. 163352. 
Venericardia globosa, new species.

(Plate 15, Figures $4 a-c$.)

The following is a description of this species:

Shell orbicular, highly inflated; ribs more than 20 , with nearly equal interspaces; beaks medial, low; margins crenulated within.

Alt., $33.5 \mathrm{~mm}$.; lon., 35.5, mm.; diam. of left valve, $19 \mathrm{~mm}$.

The species grew to be at least twice as large as the specimen measured.

All the specimens of this species are so badly worn as to prevent accurate determination of the sculpture; 20 ribs can be counted on the type specimen, and it is probable that at least 5 more were originally present. Where the ribs have been partly eroded they present a peculiar cellular structure, beneath which may be discerned concentric sculpture of close, wavy threads.

This species, remarkable for its inflation, can not be confused with any other known American species. Venericardia bulla, which, perhaps, is as close to this species as any other, is less inflated, much longer, and has higher beaks.

Localities.-Point between Colombier Point and bay next to St. Jean Bay and point between Anse Écaille and Anse Lézard, St. Bartholomew (stations $6897 b$ and 6897), Vaughan.

Geologic horizon.-Eocene.

Type.-U. S. Nat. Mus. No. 167196.

Venericardia vaughani, new species.

(Plate 16, Figures $2 a-c$.)

The following is a description of this species:

Shell subquadrate; beaks high, prosogyrate, situated near the anterior quarter; ribs about 17 , broad, separated by nearly equally wide interspaces; ribs on the anterior third set with transversely elongated nodes, other ribs rounded, flattened, or acutish.

Alt., $45 \mathrm{~mm}$.; lon., $47 \mathrm{~mm}$.; diameter, about $30 \mathrm{~mm}$.

Locality.-Point between Anse Ecaille and Anse Lézard, St. Bartholomew, station 6897 , Vaughan.

Geologic horizon.-Eocene.

Type.-U. S. Nat. Mus. No. 167195.

\section{Venericardia species.}

(Plate 16, Figure 3.)

A fragment of the left valve of a large species of Venericardia was found at station 6897, St. Bartholomew. It appears to be related to Venericardia planicosta, but possesses nodules on the anterior ribs and its lunule is not erect as in that species.

Locality.-Point between Anse Ecaille and Anse Lézard, St. Bartholomew, station $6897 a$, Vaughan.

Geologic horizon.-Eocene.

Figured specimen.-U. S. Nat. Mus. No. 167197. 
Argyrotheca dalli, new species.

(Plate 16, Figures $5 a-c$.)

The following is a description of this species:

Shell minutely punctate, with many simple, rounded ribs increasing in number by intercalation; dorsal valve flat; ventral valve inflated; cardinal areas high, triangular in ventral valve, linear in dorsal valve; delthyrium (probably) triangular; median septum of dorsal valve high in front, nearly meeting the opposite valve, very low at beak.

Alt. of ventral valve, $13.3 \mathrm{~mm}$; alt. of dorsal valve, $10 \mathrm{~mm}$.; width, 12.5 mm.; diam., $7 \mathrm{~mm}$.

Guppy ${ }^{1}$ lists Argiope clevei Davidson from St. Bartholomew, but I have been unable to find any other reference to that species. It may be the form here described.

Localities.-Point between Anse Ecaille and Anse Lézard and point between Colombier Point and bay next St. Jean Bay, St. Bartholomew, stations $6897 a, b$, Vaughan.

Geologic horizon.-Upper Eocene.

Type.-U. S. Nat. Mus. No. 167201.

Liothyrina vaughani, new species.

(Plate 16, Figures $1 a-c$.)

The following is a description of this species:

Shell large, inflated, glabrous; dorsal valve suborbicular, ventral valve ovate, occasionally prolonged in a linguiform projection filling a corresponding emargination in the dorsal valve; beak closely incurved; foramen small, circular.

Length, $43 \mathrm{~mm}$.; breadth, $36 \mathrm{~mm}$.; thickness, $18.5 \mathrm{~mm}$.

This species was identified as Terebratula carneoides Guppy by Cleve, ${ }^{2}$ but the beak of Liothyrina vaughani is more closely incurved than that of any previously described species from the American Tertiary.

Locality. - Northwest side of St. Jean Bay, St. Bartholomew, station 6924, Vaughan.

Geologic horizon.-Upper Eocene.

Type.-U. S. Nat. Mus. No. 167202.

\section{BRACHIOPODS FROM TRINIDAD.}

For the sake of completeness, references are included to 3 species of Liothyrina from San Fernando, Trinidad. The types are in the collection of the U. S. National Museum.

Terebratula trinitatensis Guppy, Quart. Journ. Geol. Soc. London, vol. 22, p. 296, plate 19. figs. $1 a, 1 b, 1866$.

Terebratula carneoides Guppy, loc. cit., p. 296, plate 19, fig. 2, 1866.

Terebratula lecta Guppy, loc. cit., p. 296, plate 19, fig. 3, 1866.

1 Guppy, R. J. L., Geol. Mag., Dec. 2, vol. 1, p. 443, 1874.

${ }^{2}$ K. svenska Vet.-Akad., Handl. Bd. 9, No. 12, p. 26, 1871. 


\section{DESCRIPTION OF PLATES.}

\section{Plate 1.}

Fig. 1. Oliva sp. Ventral view. Crocus Bay, Anguilla. $\times 1.5$. Page 111.

Figs. 2, 3a-b. Levifusus? angelicus, n. sp. (2) Dorsal view. Bejucal, Cuba. $\times 1.5 .(3 a)$ Ventral view of smaller individual from same locality. $\times 3 . \quad(3 b)$ Dorsal view of same specimen. $\times 3$. Page 111.

Fig. 4. Lyria vaughani, n. sp. Dorsal view. Crocus Bay, Anguilla. $\times 1.5$. Page 111.

Frgs. $5 a-b, 6 a-b$. Conus sp. (5a) Apieal view of cast. Crocus Bay, Anguilla. $\times 1.5 . \quad(5 b)$ Ventral view of same specimen. $\times 1.5$. (6a) Apical view of cast of another individual, Crocus Bay. $\times 1.5$. $(6 b)$ Ventral view of same specimen. $\times 1.5 . \quad$ Page 110.

Fia. 7. Cerithium herculeanum, n. sp. Ventral view. Crocus Bay, Anguilla. $\times 1.5$. Page 116. Fra. 8. Epitonium (Sthenorhytis) antiguense (Brown). Dorsal view. Hodge's Bluff, Antigua. $\times 1.5$. Page 112 .

Figs. $9 a, b$. Cyproca anguillana, n. sp. $(9 a)$ Ventral view. Crocus Bay, Anguilla. $\times 1.5 . \quad(9 b)$ Dorsal view of same specimen, $\times 1.5$. Page 114 .

Figs. $10 a, b$. Cyproaa semen, n. sp. (10a) Ventral view. Bejucal, Cuba. $\times 3$. (10b) Dorsal view of same specimen. $\quad \times 3$. Page 114 .

\section{Plate 2.}

Figs. 1, 2. Orthaulax inornatus Gabb. (1) Ventral view. Consolacion del Sur, Cuba. $\times 1$. (2) Ventral view of fragment from same locality. $\times 1$. Page 116.

Frgs. 3, 4. Orthaulax pugnax (Heilprin). (3) Ventral view. Crocus Bay, Anguilla. $\times 1$. (4) Young individual. Antigua. $\times 1$. Page 115.

Figs. $5 a, b$. Strombus sp. (5a) Ventral view of young individual. Crocus Bay, Anguilla. $\times 1$. (5b) Dorsal view of same specimen. $\times 1$. Page 115.

\section{Plate 3.}

Figs. $1 a, b$. Hemisinus costatus, n. sp. (1a) Ventral view of type. Bejucal, Cuba. $\times 3 . \quad(1 b)$ Dorsal view of same specimen. $\times 3$. Page 117.

Fig. 2. Hemisinus bituminifer, n. sp. Ventral view of type. Bejucal, Cuba. $\times 3$. Page 118. Fı. 3. Hemisinus siliceus Brown and Pilsbry. Ventral view. Dry Hill Point, Antigua. $\times 1.5$. Page 119.

Figs. 4, 5. Hemisinus atriformis, n. sp. (4) Dorsal view of type. Dry Hill Point, Antigua. $\times 2$ (5) Ventral view of anotherindividual from same locality. $\times 2$. Page 118.

Figs. 6, 7, 8, 9. Hemisinus antiguensis Brown and Pilsbry. (6) Ventral view of smoother variety. Dry Hill Point, Antigua. $\times 1.5$. (7) Ventral view. Dry Hill Point, Antigua. $\times 5$. (8) Ventral view of young specimen. Dry Hill Point, Antigua. $\times 5$. (9) Fragment from same locality. $\times 5$. Page 118.

Figs. $10 a, b, 11,12 a, b$. Cerithidea? anguillana, n. sp. (10a) Ventral view of young individual. Crocus Bay, Anguilla. $\times 5$. (10b) Dorsal view of same specimen. $\times 5$. (11) Dorsal view of type. Same locality. $\times 5$. (12a) Dorsal view of young individual. Same locality. $\times 5$. (12b) Ventral view of same specimen. $\times 5$. Page 117.

\section{Plate 4.}

Figs. 1, 2, 3. Turritella anguillana, n. sp. (1) Fragment. Crocus Bay, Anguilla. $\times 1.5$. (2) Fragment from same locality. $\times 1.5$. (3) Fragment from same locality. $\times 1.5$. Page 120.

Fig. 4. Turritella dubiosa, n. sp. View of type specimen. Crocus Bay, Anguilla. $\times 1.5$. Page 120.

Figs. 5, 6, 7. Turritella forresti Brown. (5) Ventral view. St. Johns, Antigua. $\times 3$. (6) Dorsal view of another specimen from same locality. $\times 3$. (7) Dorsal view of another specimen from same locality. $\times 3$. Page 121.

Fig. 8. Turritella crocus, n. sp. Ventral view of type. Crocus Bay, Anguilla. $\times 1.5$. Page 121.

Figs. $9 a, b$. Ampullina anguillana, n. sp. (9a) Ventral view of type. Crocus Bay, Anguilla. $\times 1.5$. $(9 b)$ Dorsal view of same specimen. $\times 1.5$. Page 123.

Fra. 10. Solarium sp. Fragment. Crocus Bay, Anguilla. $\times 5 . \quad$ Page 122. 


\section{Plate 5.}

Fias. 1, 2, 3. Ampullina (Ampullinopsis) spenceri, n. sp. (1) Ventral view of first cotype. Antigua. $\times 1$. (2) Ventral view of second cotype. Antigua. $\times 1$. (3) Ventral view of a larger specimen. Willoughby Bay, Antigua. $\times 1$. Page 123.

Fras. 4 a-c. Turbo antiguensis, n. sp. (4a) Ventral view of type. Rifle Butts, Antigua. $\times 1$. (4b) Basal view of same specimen. $\times 1$. (4c) Dorsal view of same specimen. $\times 1$. Page 125.

Frgs. $5 a$, b. Margarita naticoides, n. sp. $(5 a)$ Ventral view of type. Bejucal, Cuba. $\times 1 . \quad(5 b)$ Dorsal view of same specimen. $\times 1$. Page 125.

Fras. $6 a$, b. Sinum chipolanum (Dall). (6a) Ventral view. Crocus Bay, Anguilla. $\times 2$.

- (6b) Dorsal view of same specimen. $\times 2$. Page 124.

Figs. 7, 8. Neretiną grandis, n. sp. (7) Dorsal view of type. Anse Lézard, St. Bartholomew. $\times$ 1. (8) Dorsal view of large specimen. St. Jean Bay, St. Bartholomew. $\times 1$. Page 126.

Fras. 9 a-c. Elmira cornu-arietis, n. sp. (9a) Ventral view of type. Bejucal, Cuba. $\times 1 . \quad(9 b)$ Apical view of same specimen. $\times 1$. (9c) Dorsal view of same specimen. $\times 1$. Page 123.

Fras. $10 a, b$. Scapharca anguillana, n. sp. (10a) Exterior of right valve of type. Crocus Bay, Anguilla. $\times 1$. (10b) Interior of same specimen. $\times 1$. Page 127.

Figs. $11 a, b$. Scapharca willobiana, n. sp. (11a) Right valve of type. Willoughby Bay, Antigua. $\times 1$. (11b) Left valve of same specimen. $\times 1$. Page 127.

\section{Plate 6.}

Figs. $1 a, b, 2 a, b$. Ostrea antiguensis Brown. (1a) Exterior of upper valve. Rifle Butts, Antigua. $\times 0.75$ (1b) Exterior of lower valve of same specimen. $\times 0.75(2 a) \mathrm{Ex}$ terior of lower valve. Same locality. $\times 0.75$ (2b) Interior of same specimen. $\times 0.75$ Page 128 .

\section{Plate 7.}

Figs. 1, 2. Ostrea haitensis Sowerby. (1) Interior of valve. Santiago, Cuba. $\times 1$. (2) Inte rior of lower valve of young individual. Santiago, Cuba. $\times 1.5$. Page 129.

FIg. 3. Pecten nodosissimus, n. sp. Right valve. Willoughby Bay, Antigua. $\times 1.5$. Page 141 .

Figs. $4 a, b$. Pecten waylandi, n. sp. (4a) Left valve of type. Santiago, Cuba. $\times 1.5$. (4b) Right valve of same individual. $\times$ 1.5. Page 131.

Figs. 5, 6. Pecten gardnerœ, n. sp. (5) Left valve. Santiago, Cuba. $\times 1.5$. (6) Right valve of another individual. Santiago, Cuba. $\times 1.5$. Page 134.

Figs. 7, 8. Pecten articulosus, n. sp. (7) Right valve, type. Guajay, Cuba. $\times 1 . \quad$ (8) Left valve of another individual. Guajay, Cuba. $\times 1$. Page 136.

\section{Plate 8.}

Fra. 1. Ostrea haitensis Sowerby. Exterior. La Cruz, Cuba. $\times 0.5$. Page 129.

Figs. 2, 3, 4. Pecten vaughani, n. sp. (2) Left valve. Crocus Bay, Anguilla. $X$ 1.5. (3) Right valve of type. Crocus Bay, Anguilla. $\times 1.5$. (4) Right valve. Crocus Bay, Anguilla. $\times 1.5$. Page 133.

Fig. 5. Pecten oxygonum Sowerby? Right valve. Hodge's Bluff, Antigua. $\times 1.5$. Page 137 .

Fras. $6 a, b$, 7. Pecten vaughani var. flabellum, n. var. $(6 a)$ Left valve of type. Santiago, Cuba. $\times$ 1.5. $(6 b)$ Right valve of type. $\times 1.5$. (7) Right valve. La Cruz, Cuba. $\times$ 1.5. Page 134 .

Figs. 8, 9, 10. Pecten perplexus, n. sp. (8) Right valve. Crocus Bay, Anguilla. $\times 1.5$. (9) Left valve. Crocus Bay, Anguilla. $\times$ 1.5. (10) Detail of sculpture. Crocus Bay, Anguilla. Greatly enlarged. Page 138.

\section{Puate 9.}

Fic. 1. Ostrea cf. O. trigonalis Conrad. Upper valve. St. Jean Bay, St. Bartholomew. $\times 0.75$. Page 129.

Figs. $2 a, b$. Pecten crocus, n. 8p. (2a) Right valve. Crocus Bay, Anguilla. $\times 1$. (2b) Left valve of same individual. $\times 1$. Page 135.

Figs. 3 a-c. Unio bitumen, n. sp. (3a) Right valve. Bejucal, Cuba. $\times 0.75$. (3b) Left valve of same individual. $\times 0.75$. (3c) Dorsal view of same individual. $\times 0.75$. Page 130.

Figs. $4 a$, b. Pinna vaughani, n. sp. (4a) Right valve. Crocus Bay, Anguilla. $\times 1 . \quad(4 b)$ Left valve of same specimen, tilted to show ventral sculpture. $\times 1$. Page 127. 
Plate 10.

Frgs. $1 a, b, 2$. Pecten anguillensis Guppy. (1a) Right valve of type. Anguilla. $\times 1.5$. (1b) Left valve of type. $\times 1.5$. (2) Left valve. Willoughby Bay, Antigua. $\times 1.5$. Page 132.

Figs. 3, 4. Pecten clevei, n. sp. (3) Left valve. Crocus Bay, Anguilla. $X$ 1.5. (4) Right valve. Crocus Bay, Anguilla. $\times 1.5$. Page 132.

Fra. 5. Pecten perlineatus, n. sp. Type. Willoughby Bay, Antigua. $\times 1.5$. Page 141.

Frg. 6. Pecten nugenti Brown? Fragment. Hodge's Bluff, Antigua. $\times 1.5 . \quad$ Page 141 .

Frg. 7. Pecten ef. $P$. oxygonum Sowerby. Right valve. Willoughby Bay, Antigua. $\times 1.5$. Page 138.

Figs. 8, $9 a, b$. Pecten crucianus, n. sp. (8) Right valve. La Cruz, Cuba. $\times 1.5$. (9a) Interior of left valve (type). Santiago, Cuba. $\times 1.5$. (9b) Exterior of type. $\times 1.5$. Page 139 .

\section{Plate 11.}

Frgs. 1, 2, 3. Pecten willobianus, n. sp. (1) Right valve. Willoughby Bay, Antigua. $\times 0.9$. (2) Right valve. Willoughby Bay, Antigua. $\times 0.9$ (3) Left valve. Willoughby Bay, Antigua. $\times 0.9$. Page 133.

FIgs. 4, 5, 6. Pecten thetidis Sowerby. (4) Right valve. Crocus Bay, Anguilla. $X 0.9$. (5) Right valve. Crocus Bay, Anguilla. $\times 3$. (6) Left valve. Crocus Bay, Anguilla. $\times 3$. Page 138.

Fias. $7 a, b, 8$. Pecten jacobianus, n. sp. (7a) Right valve of type. Santiago, Cuba. $\times 0.9$. (7b) Left valve of same specimen. $\times 0.9$. (8) Detail of sculpture of left valve. Santiago, Cuba. $\times$ 3.6. Page 139 .

FIg. 9. Pecten crocus, n. sp.? Left valve. Crocus Bay, Anguilla. $\times 0.9 . \quad$ Page 135.

Figs. $10 a, b$. Pecten duplex, n. sp. (10a) Left valve. Long Island, Antigua. $\times 0.9$. (10b) Right valve of same specimen. $\times 0.9$. Page 140 .

Fras. $11 a, b$. Spondylus bostrychites Guppy. (11a) Lower valve. Crocus Bay, Anguilla. $\quad \times 0.9$. (11b) Upper valve of same individual. $\times 0.9$. Page 144.

Figs. $12 a, b$. Plicatula densata Conrad. (12a) Interior. Santiago, Cuba. $\times 0.9 . \quad(12 b)$ Exterior of same specimen. $\times 0.9$. Page 145.

\section{Plate 12.}

FIgs. $1 a, b$. Pecten ventonensis, n. sp. (1a) Right valve. Santiago, Cuba. $\times 0.9$. (1b) Left valve of same individual. $\times 0.9$. Page 130 .

Fras. $2 a, b, 3,4,5,6,7$, Hinnites aratus, n. sp. (2a) Smaller valve of type. St. Bartholomew. $\times 0.9$. (2b) Larger valve of same specimen. $\times 0.9$. (3) Larger specimen. St. Bartholomew. $\times 0.9$. (4) Another specimen. St. Bartholomew. $\times 0.9$. (5) Posterior ear of left valve. St. Bartholomew. $\times 0.9$ (6) Details of sculpture. St. Bartholomew. $\times 3$. (7) Posterior view of type. $\times 0.9$. Page 143.

Fig. 8. Pecten gabbi Dall. Left valve. Crocus Bay, Anguilla. $\times 0.9$ Page 140.

\section{Plate 13.}

FIgs. $1 a, b$, 2. Amusium lyonii (Gabb). (1a) Left valve. Crocus Bay, Anguilla. $\times 0.9$. (1b) Right valve of same individual as fig. 1. $\times 0.9$. (2) Left valve, from same locality. $\times 3$. Page 142.

Fig. 3. Pecten perlatus, n. sp. Right valve. Crocus Bay, Anguilla. $\times 3$. Page 131.

Fig. 4. Pecten sp. Fragment. Willoughby Bay, Antigua. $\times 0.9$. Page 142.

Fig. 5. Pecten pittieri Dall. Right valve. Yumurí River, Cuba. $\times 0.9$. Page 135.

Figs. 6, 7. Amusium antiguense (Brown). (6) Interior. Hodge's Bluff, Antigua. $\times 0.9$. (7) Left valve from same locality. $\times 0.9 . \quad$ Page 143.

Figs. $8 a, b$. Pecten decorus, n. sp. (8a) Right valve. Guajay, Cuba. $\times 0.9 .(8 b)$ Left valve of same individual. $\times 0.9$. Page 137.

\section{Plate 14.}

Frg. 1. Semele? sp. Left valve. Willoughby Bay, Antigua. $\times 0.9 . \quad$ Page 147.

Figs. $2 a, b$. Metis trinitaria Dall. $(2 a)$ Left valve. Near Santiago Bay, Cuba. $\times 0.9$. Right valve of same individual. $\times 0.9 . \quad$ Page 148.

Fra. 3. Solemya sulcifera, n. sp. Type. Bejucal, Cuba. $\times 0.9$. Page 147.

Figs. 4, 5. Modiolus (Botula) cinnamomeus Lamarck. (4) Right valve. Near Santiago Bay, Cuba. $\times 0.9$. (5) Right valve of another specimen from the same locality. $\times 0.9$. Page 145. 
Plate 14-continued.

Fig. 6. Lithophaga nigra (d'Orbigny). Dorsal view. Friar's Hill, Antigua. $\times 0.9 . \quad$ Page 146. Figs. $7 a, b, 8,9 a-c$. Myrtae? asphaltica, n. sp. (7a) Left valve of young individual. Bejucal, Cuba. $\times 1.8$. (7b) Exterior of same specimen. $\times 3.6$. (8) Interior of right valve from same locality. $\times 1.8 .(9 a)$ Right valve of larger individual from same locality. $\times 0.9$. $(9 b)$ Dorsal view of same specimen. $\times 0.9 .(9 c)$ Left valve of same specimen. $\times 0.9$. Page 149.

\section{Plate 15.}

Figs. $1 a, b$. Chione spenceri, n. sp. (1a) Right valve of type. Antigua. $\times 1.5$. (1b). Left valve of same specimen. $\times 1.5$. Page 150.

Frg. 2. Phacoides (Here) sp. Right valve. Crocus Bay, Anguilla. $\times 1.5$. Page 149.

Fıgs. $3 a$, b. Phacoides (Miltha) aff. P. hillsboroënsis (Heilprin). (3a) Right valve. Santiago, Cuba. $\times 1$. $(3 b)$ Left valve of same specimen. $\times 1$. Page 149.

Figs. $4 a$-c. Venericardia globosa, n. sp. (4a) Interior of left valve. Colombier Point, St. Bartholomew. $\times 1.5$. (4b) Ventral view of same specimen. $\times 1.5$. $(4 c)$ Exterior of same specimen. $\times 1.5$. Page 151.

\section{Plate 16.}

Figs. $1 a-c$. Liothyrina vaughani, n. sp. (1a) Ventral valve. St. Jean Bay, St. Bartholomew. $\times 1$. (1b) Lateral view of same specimen. $\times 1$. (1c) Dorsal view of same specimen. $\times 1$. Page 152.

Figs. 2a-c. Venericardia vaughani, n. sp. (2a) Right valve of type. St. Bartholomew. $\times 1$. (2b) Anterior view of same specimen. $\times 1$. (2c) Left valve of same specimen. $\times$ 1. Page 151.

Fig. 3. Venericardia sp. Fragment of left valve. St. Bartholomew. $\times 1$. Page 151.

FIGs. $4 a, b$. Antigona cosarina var. anguillana, n. var. (4a) Right valve of type. Crocus Bay, Anguilla. $\times 1$. (4b) Left valve of same specimen. $\times 1$. Page 150.

Fras. $5 a-c$. Argyrotheca dalli, n. sp. (5a) Lateral view. Near Columbier Point, St. Bartholomew. $\times 3.33$. (5b) Ventral view of same specimen. $\times 3.33$. (5c) Dorsal view of same specimen. $\times 3.33$. Page 152. 

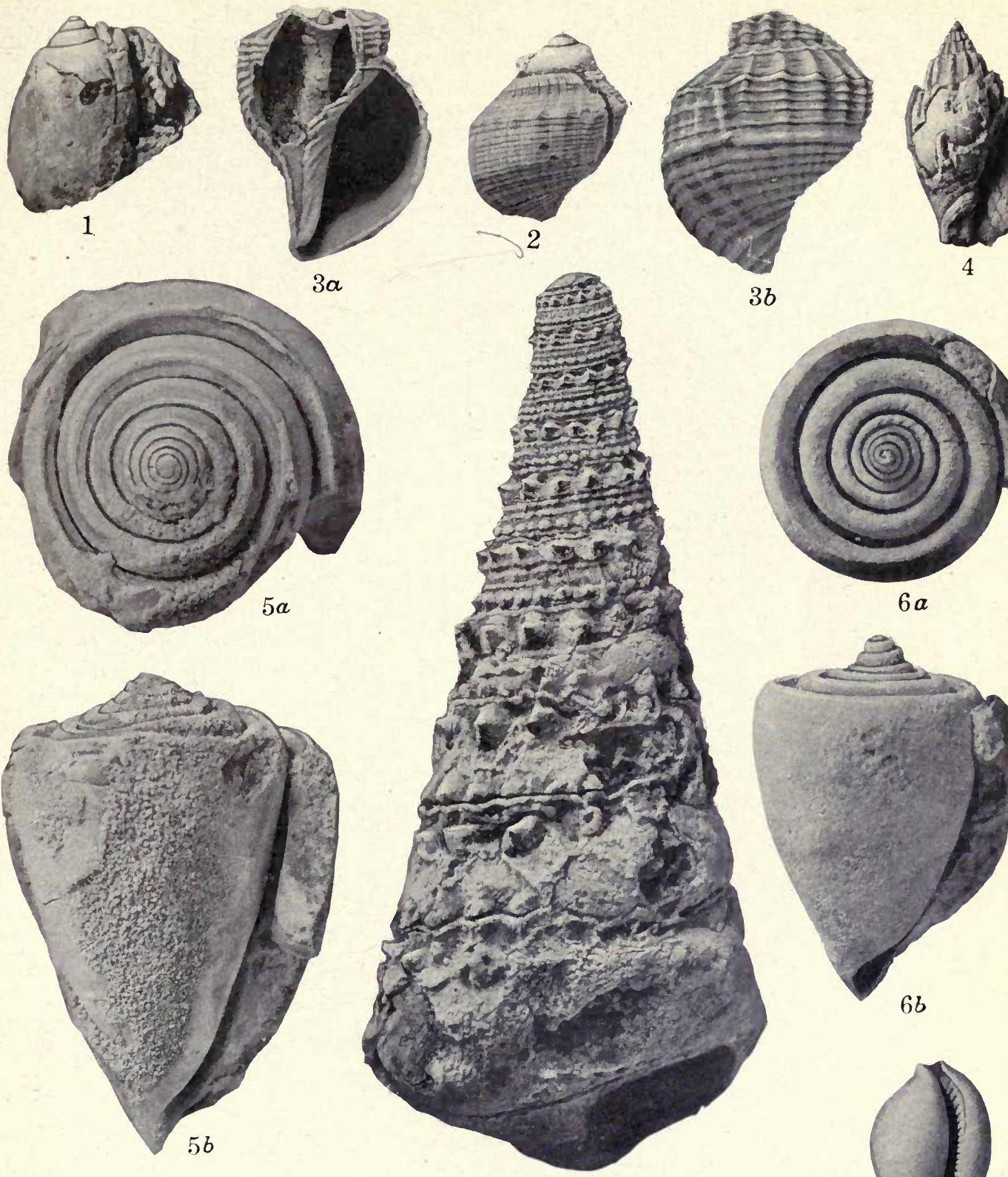

7
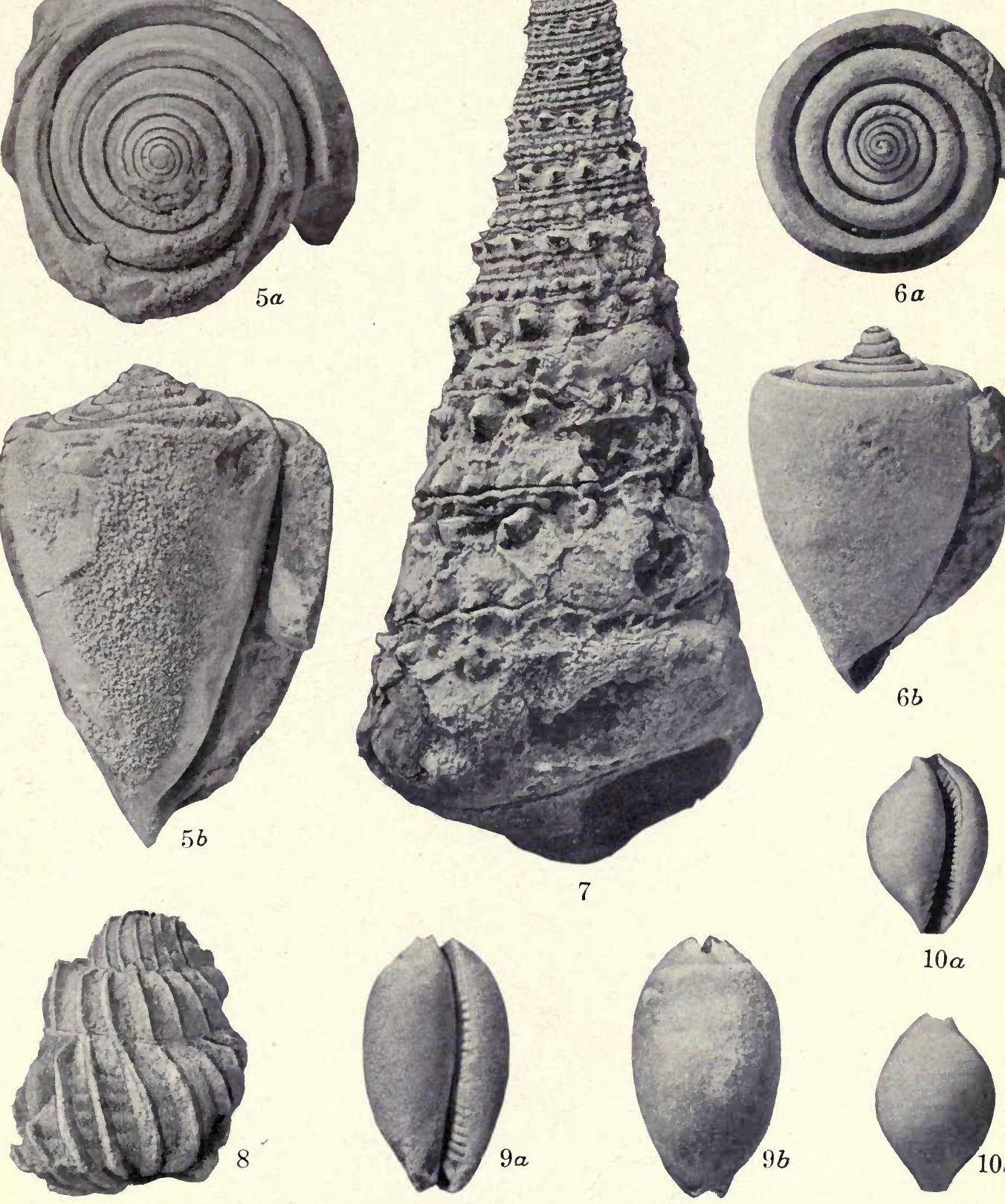

$6 b$

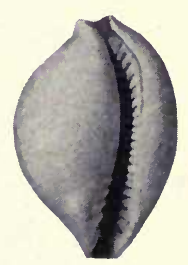

$10 \alpha$

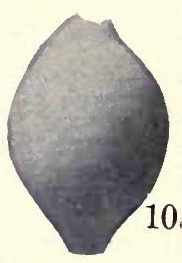



COOKE
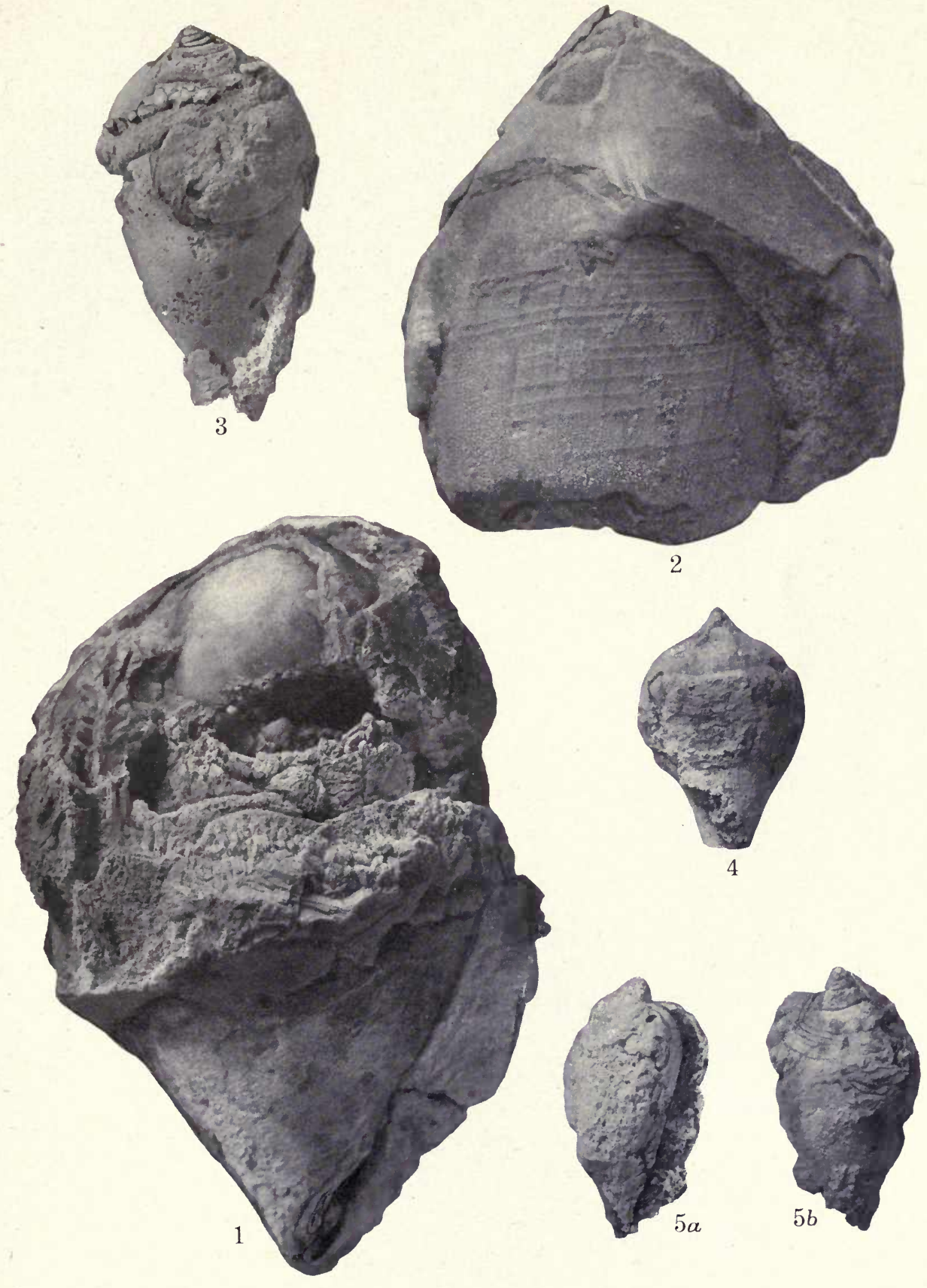

PLATE 2 



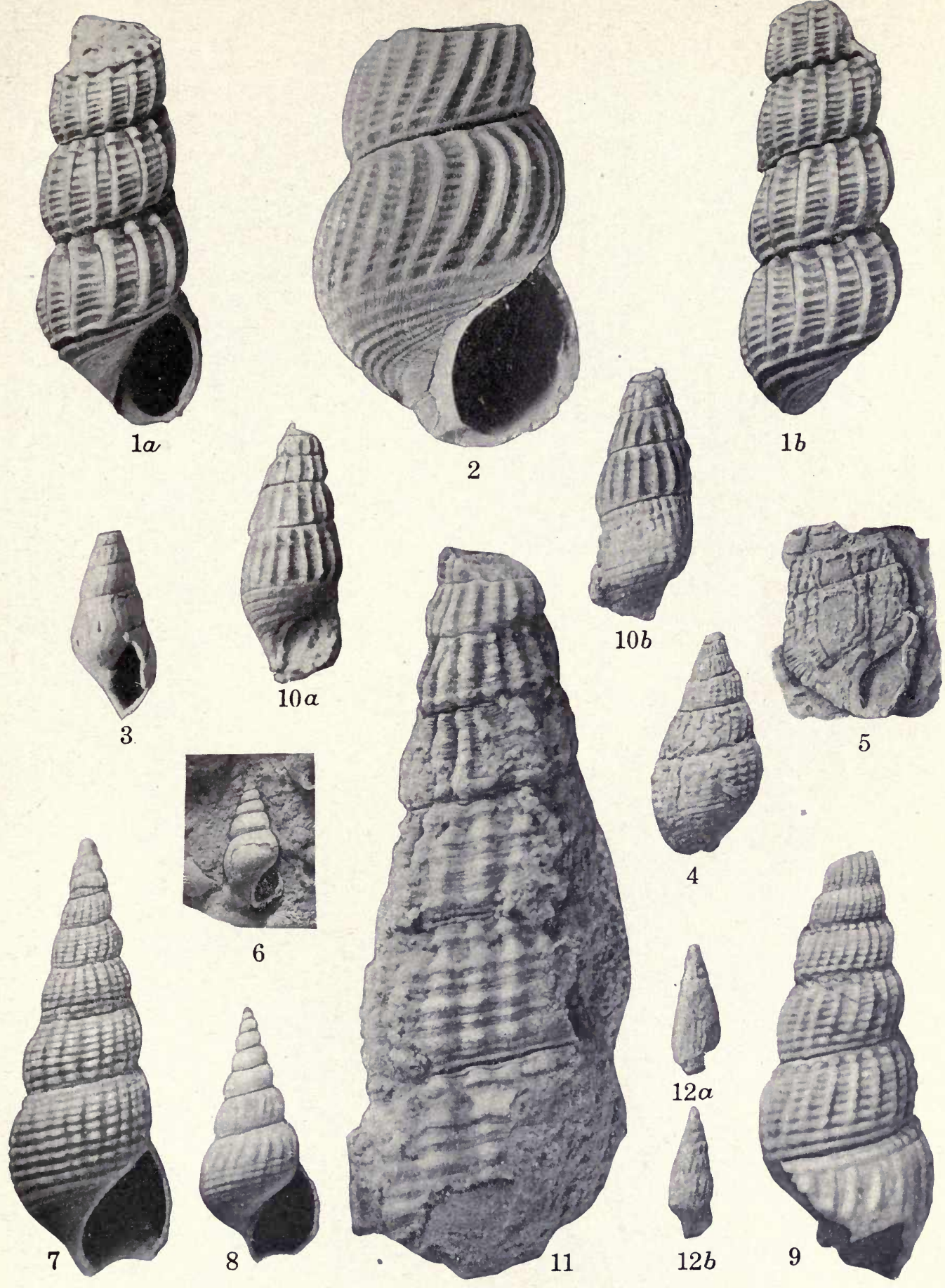




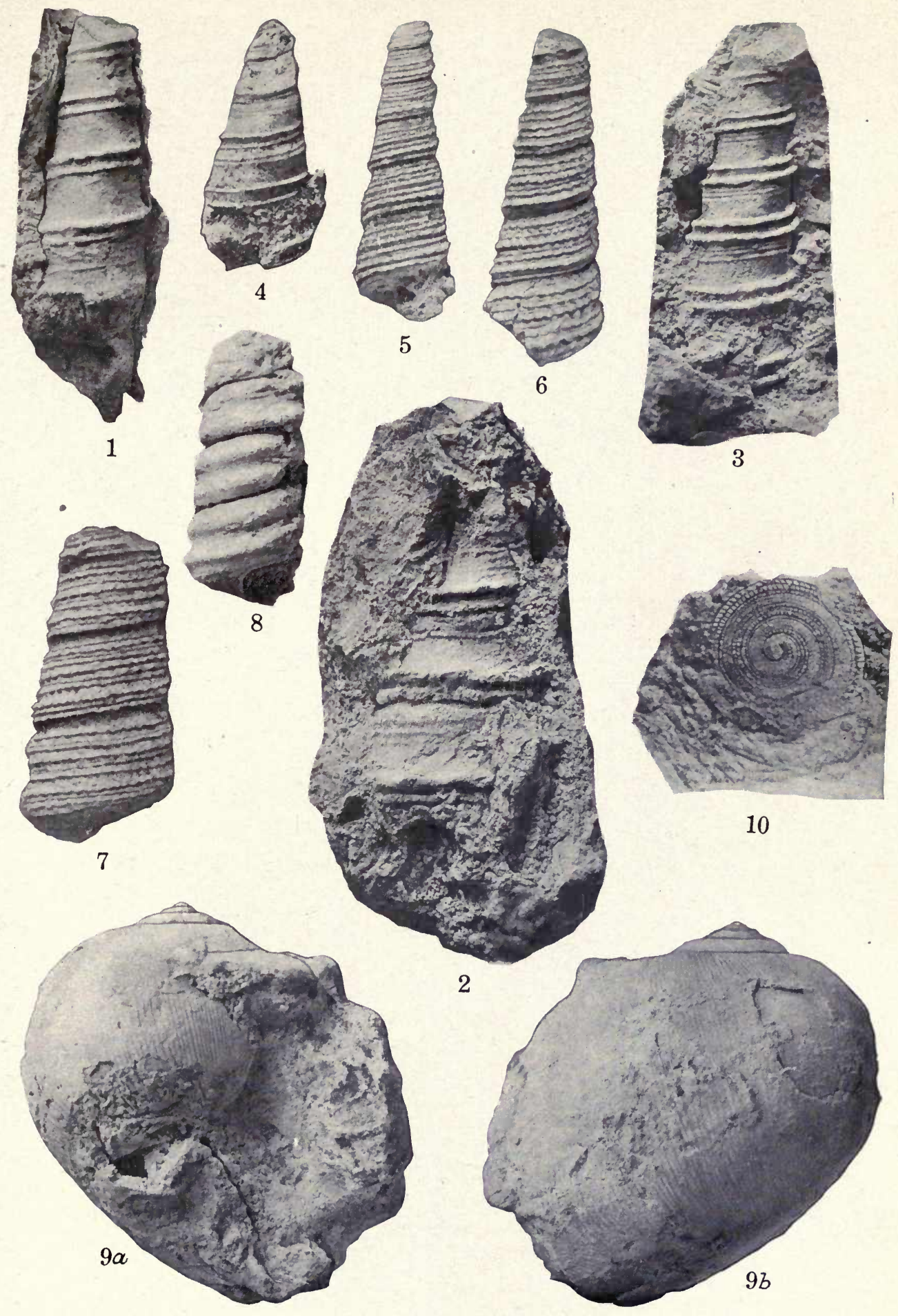



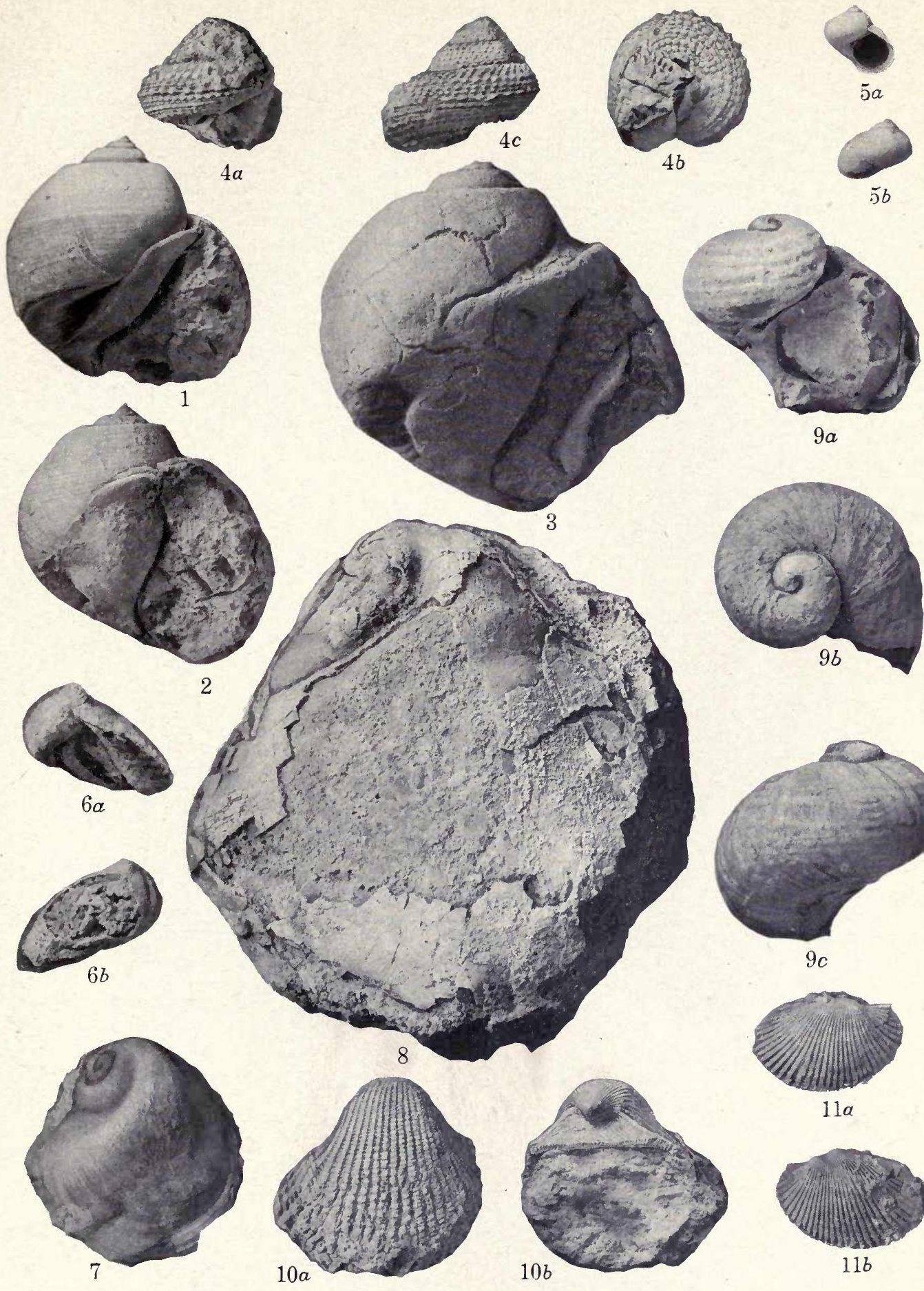




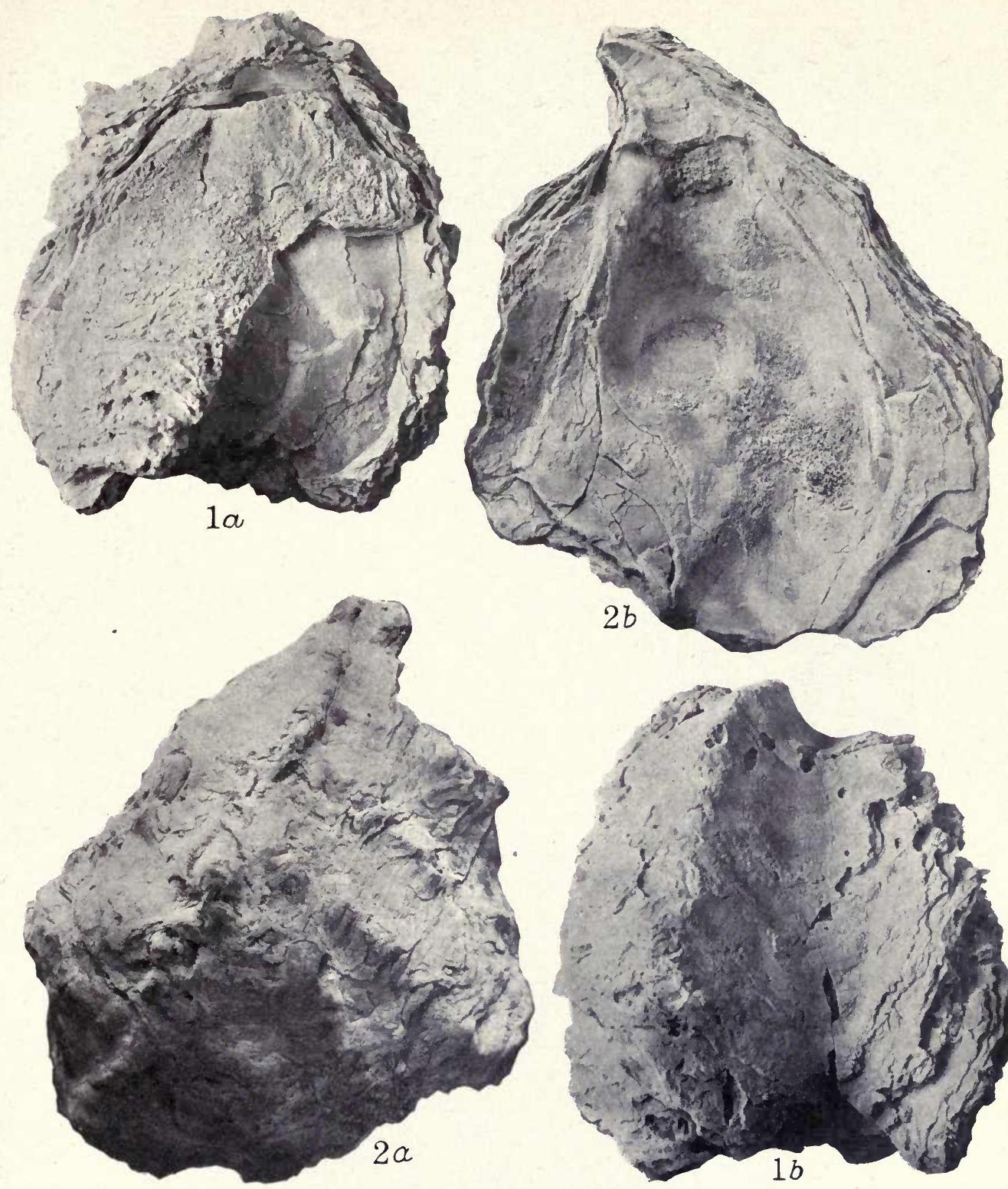

COOKE

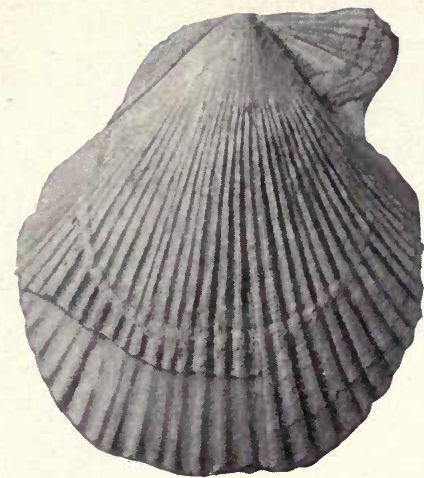

$4 b$

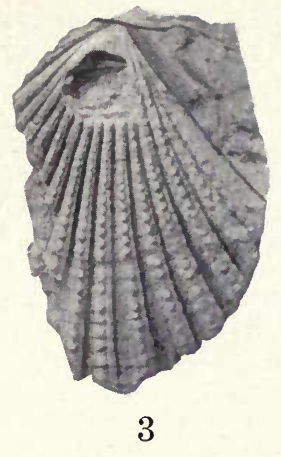

3
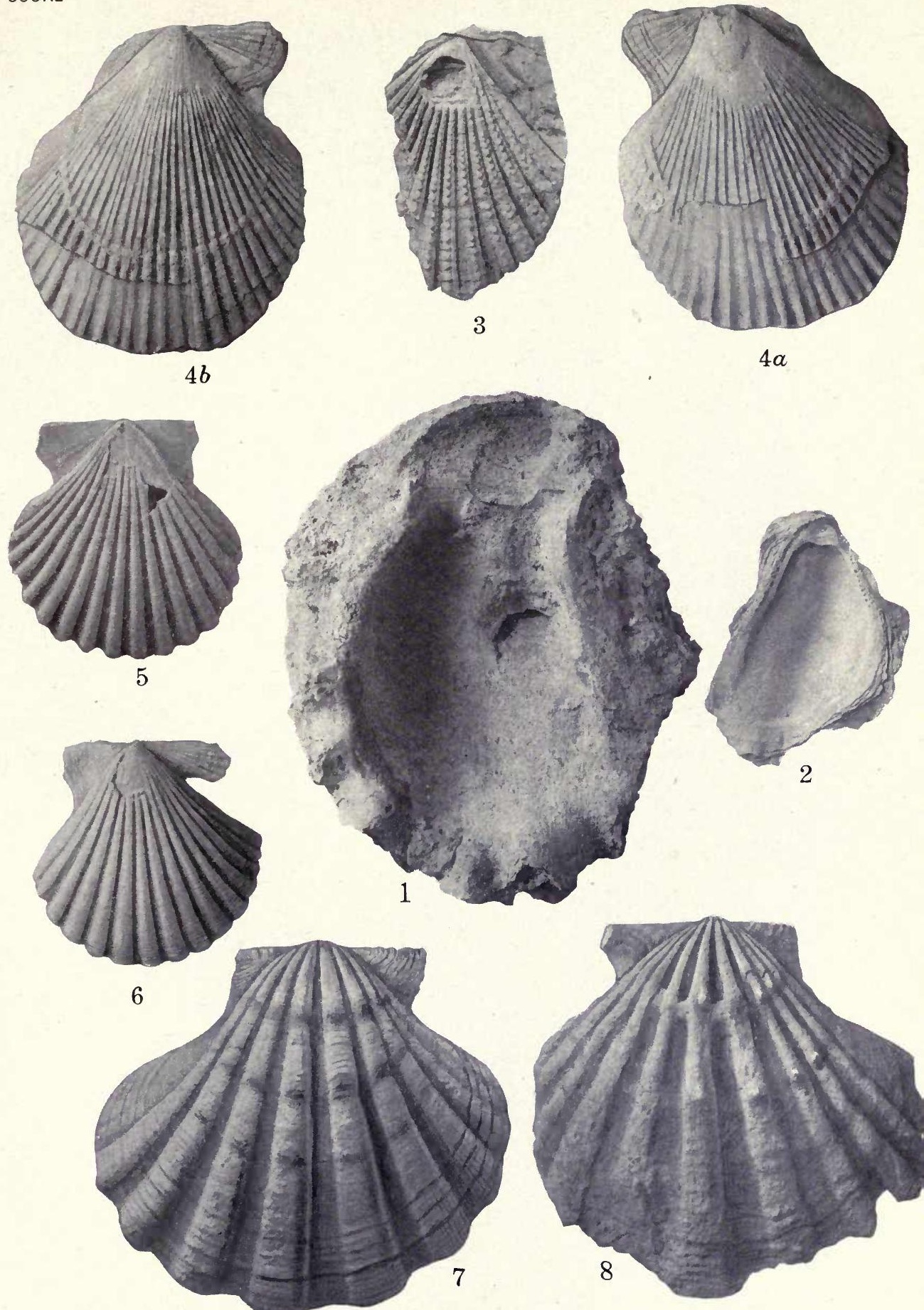

COOKE

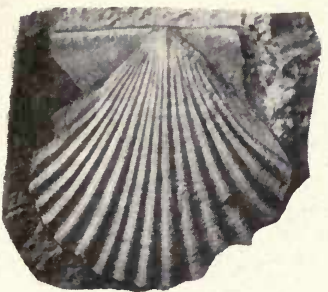

2

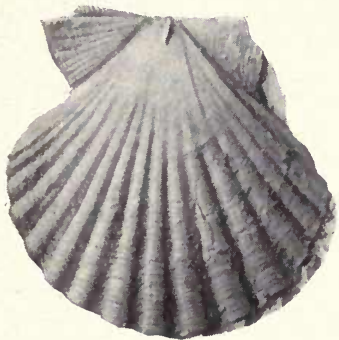

$6 a$

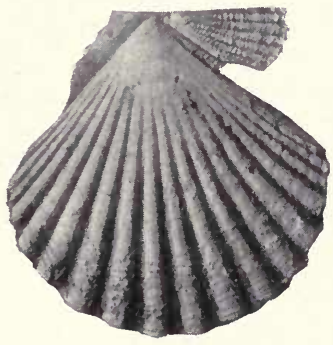

$6 b$

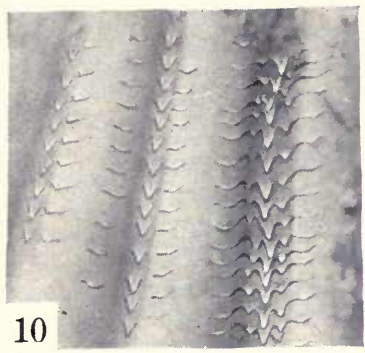

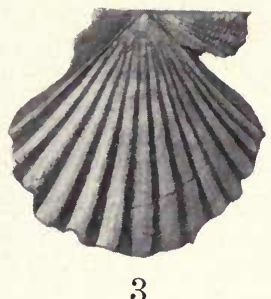

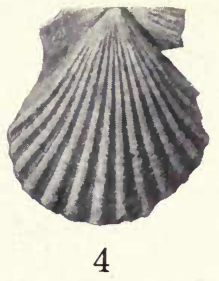

4

PLATE 8
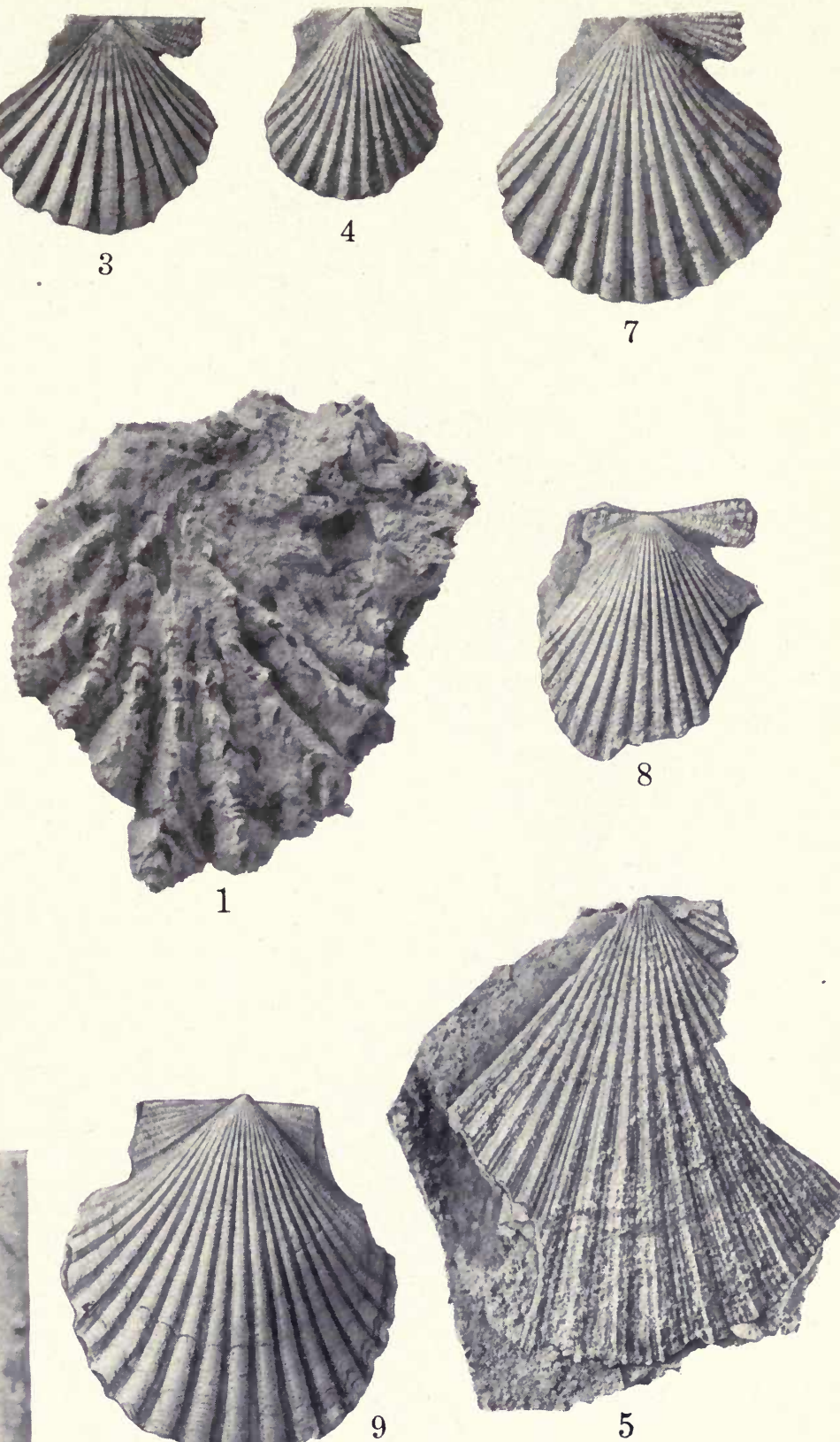

5 

COOKE
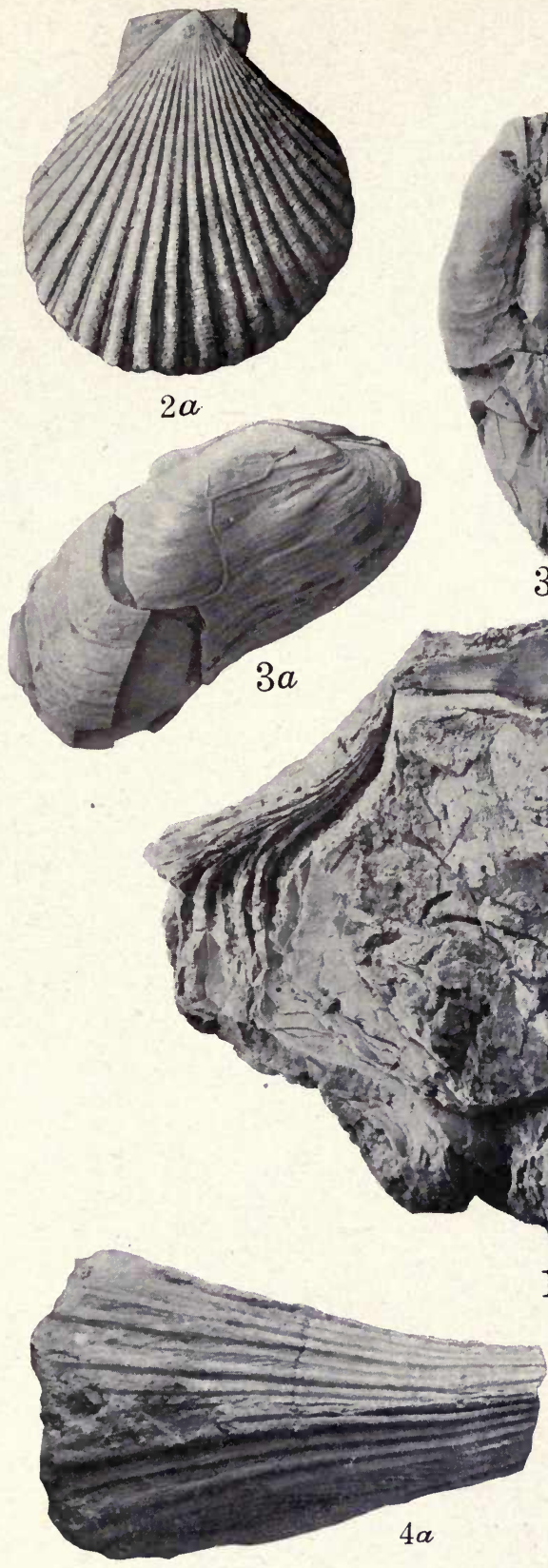

PLATE 9

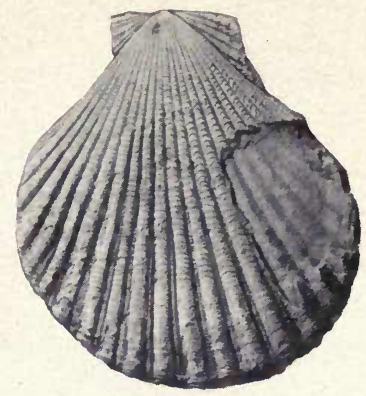

$2 b$
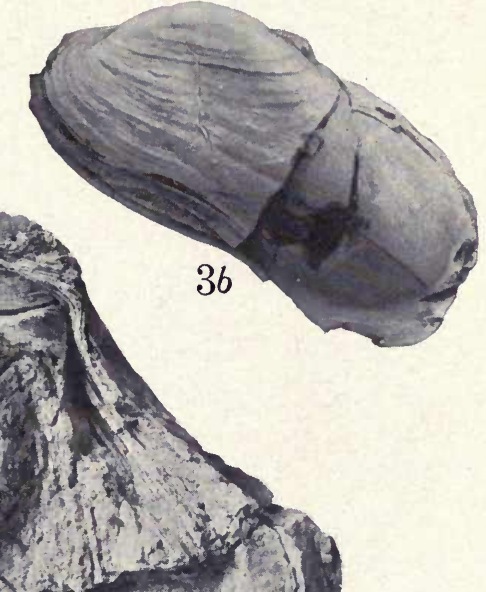

$1)^{-7}{ }^{2}$
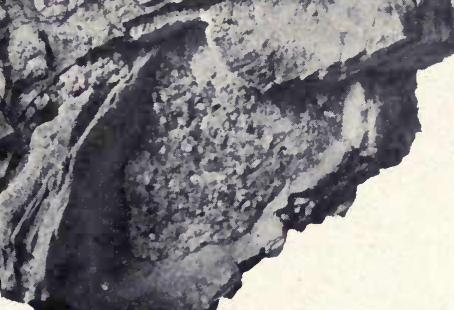

1

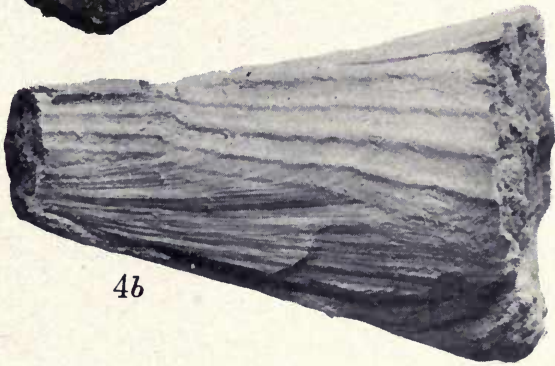




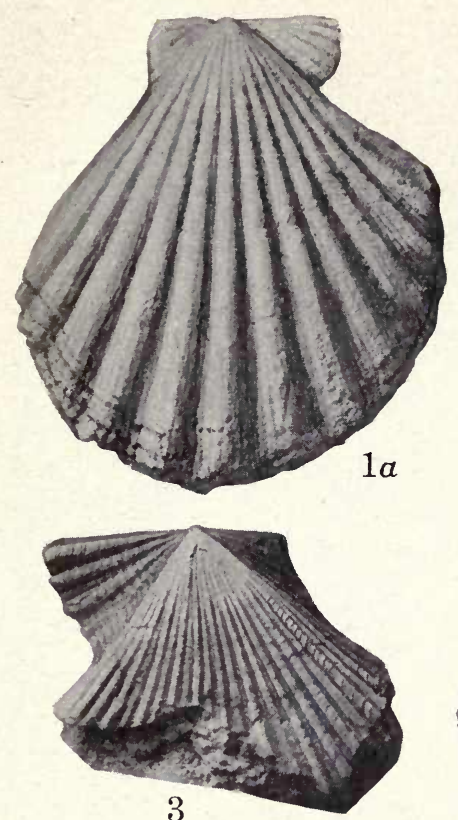

3
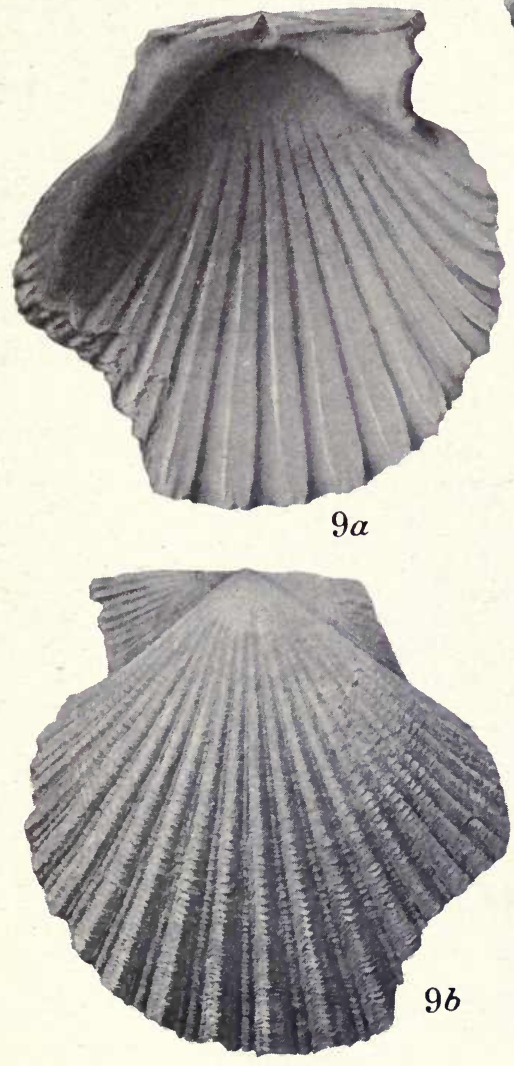
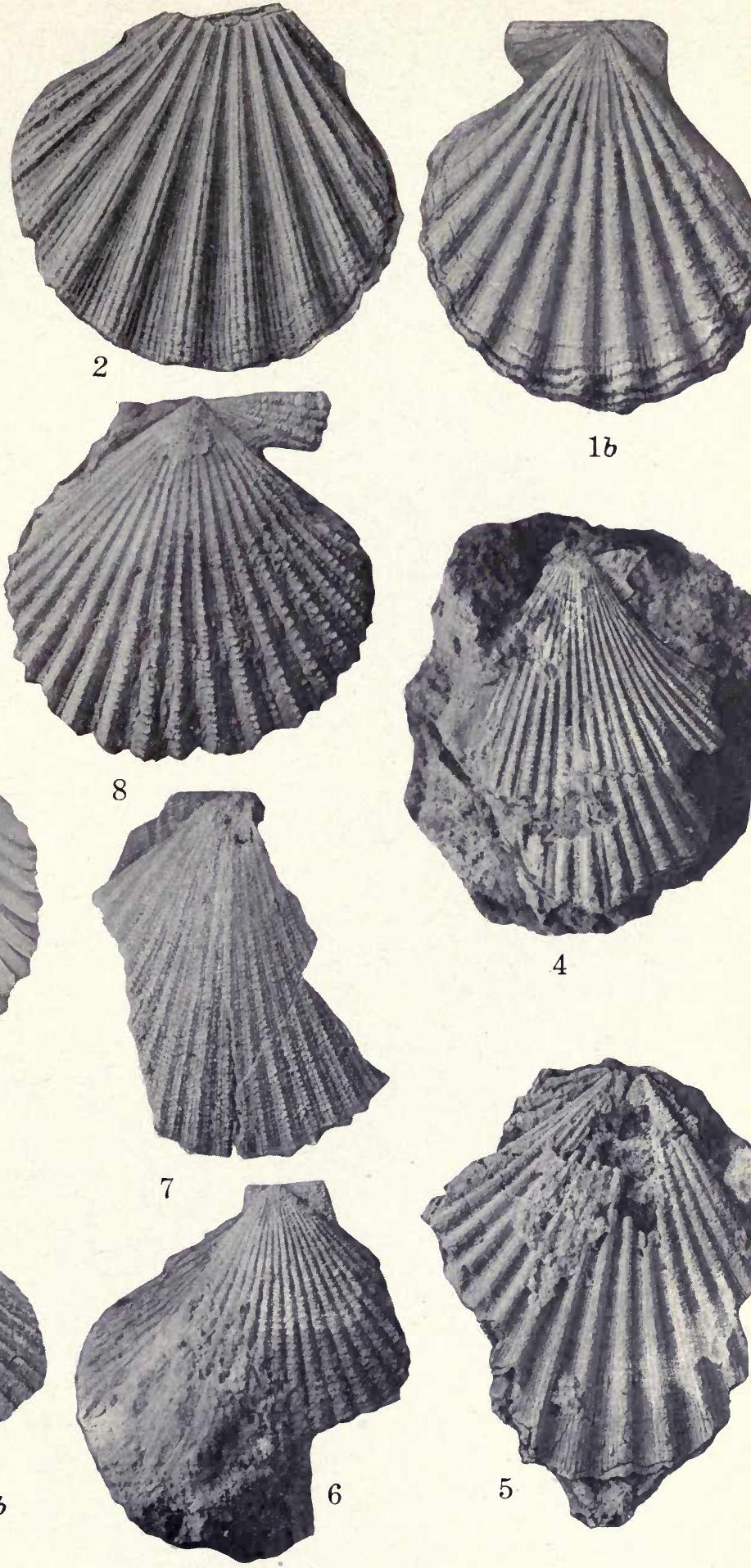

4

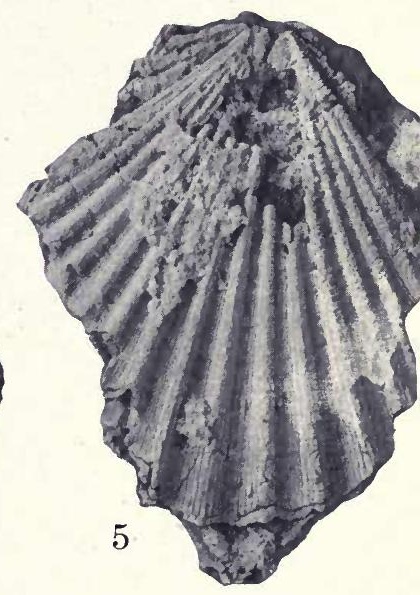



COOKE
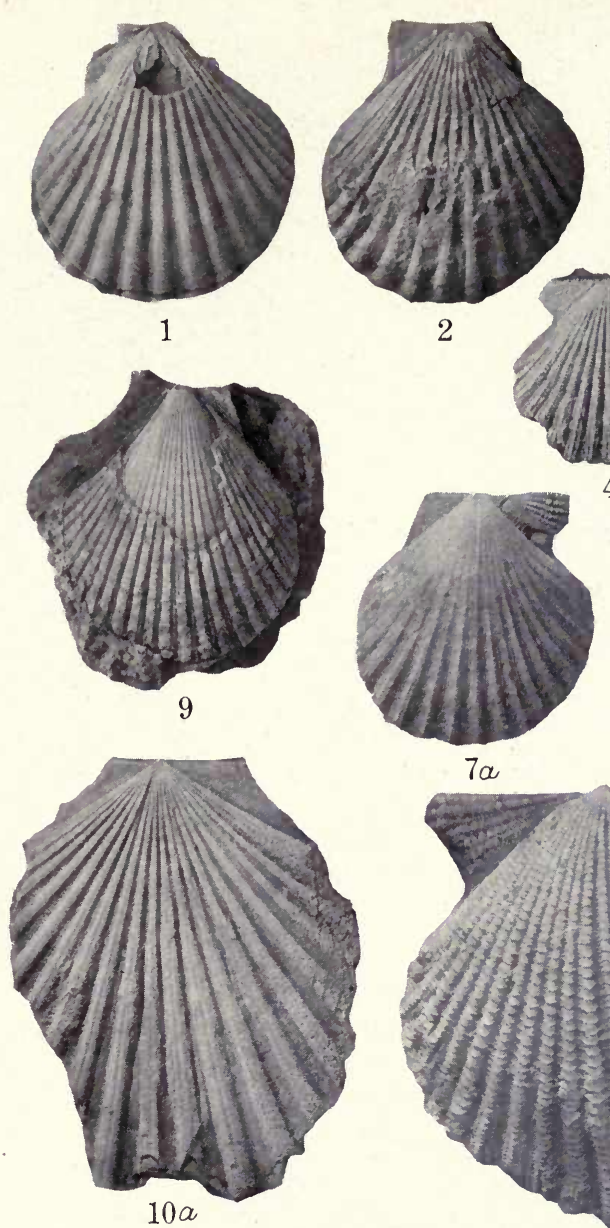

$7 a$

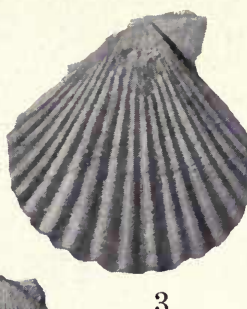

3

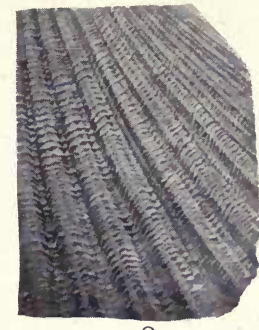

8

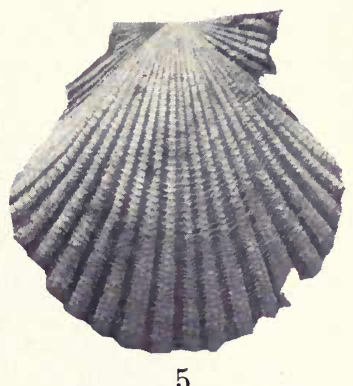

5

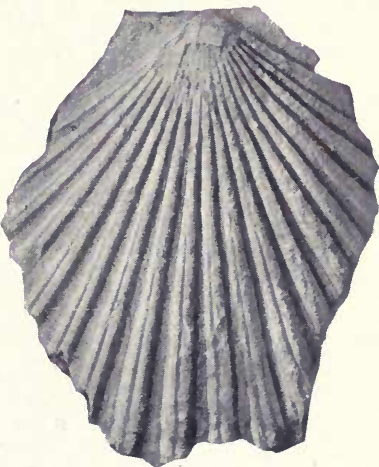

$10 b$
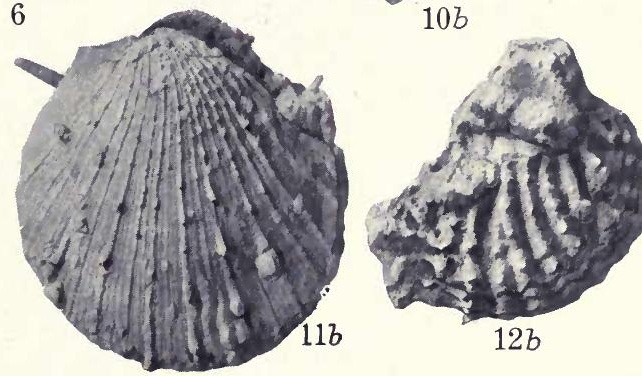

COOKE
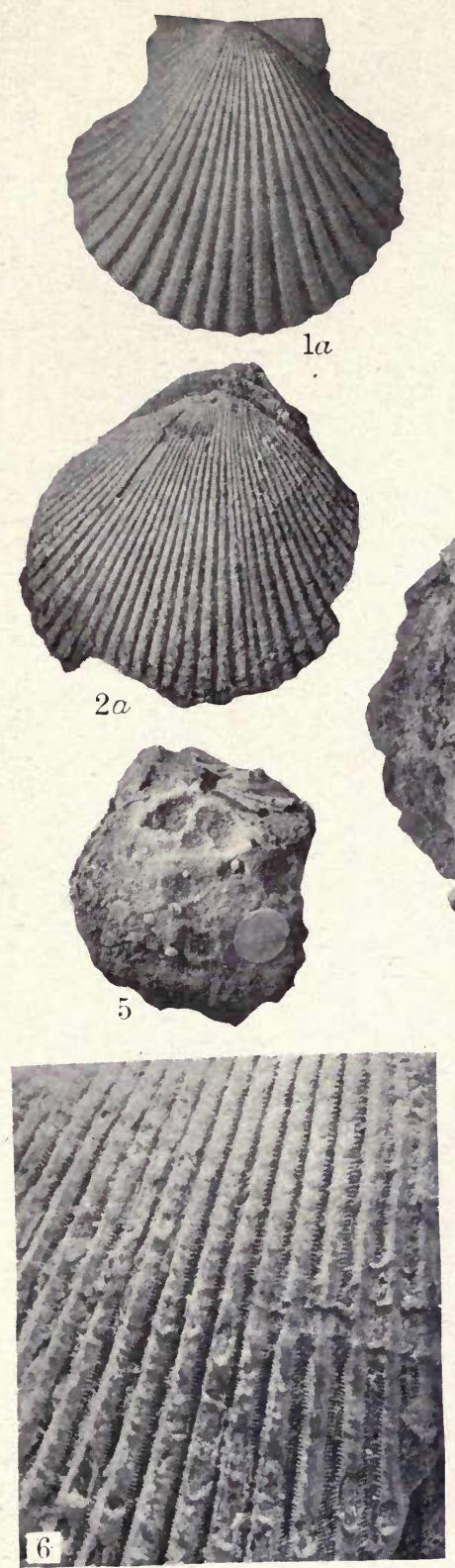

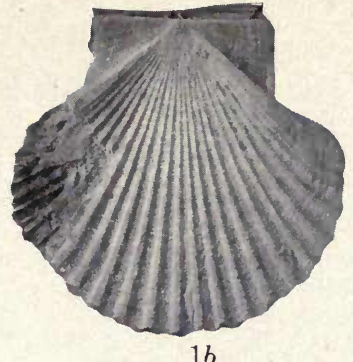

$1 b$
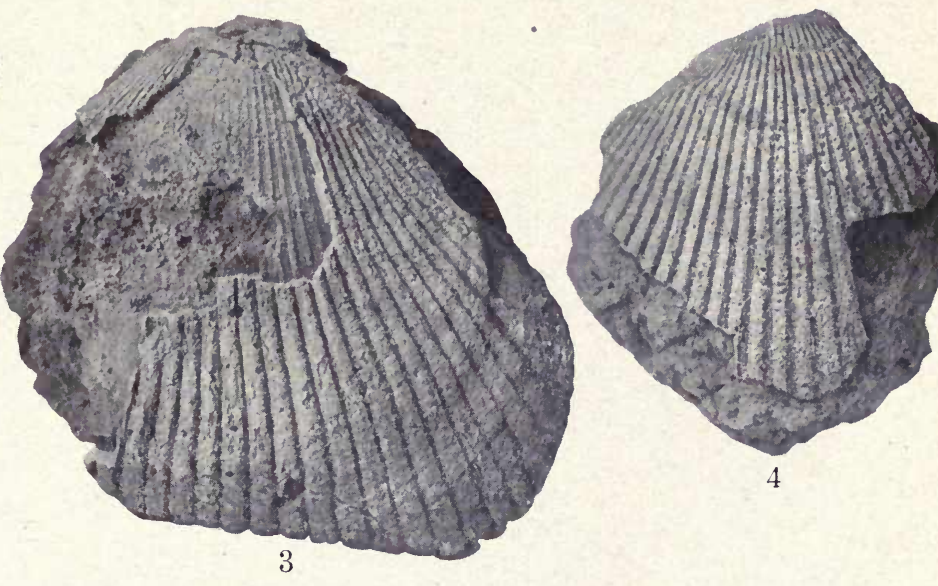

.
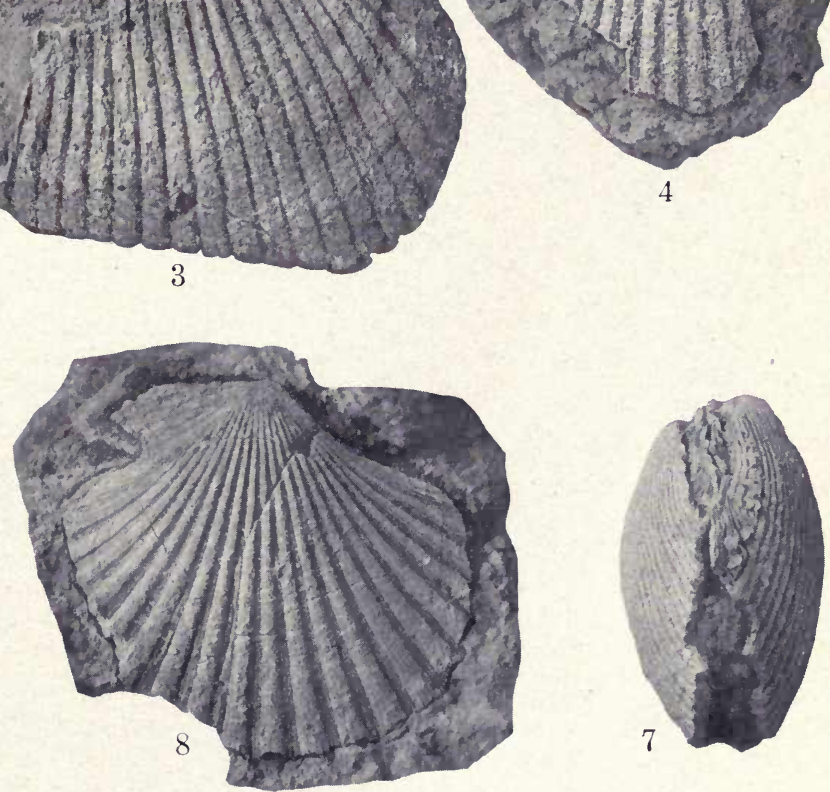

COOKE

PLATI
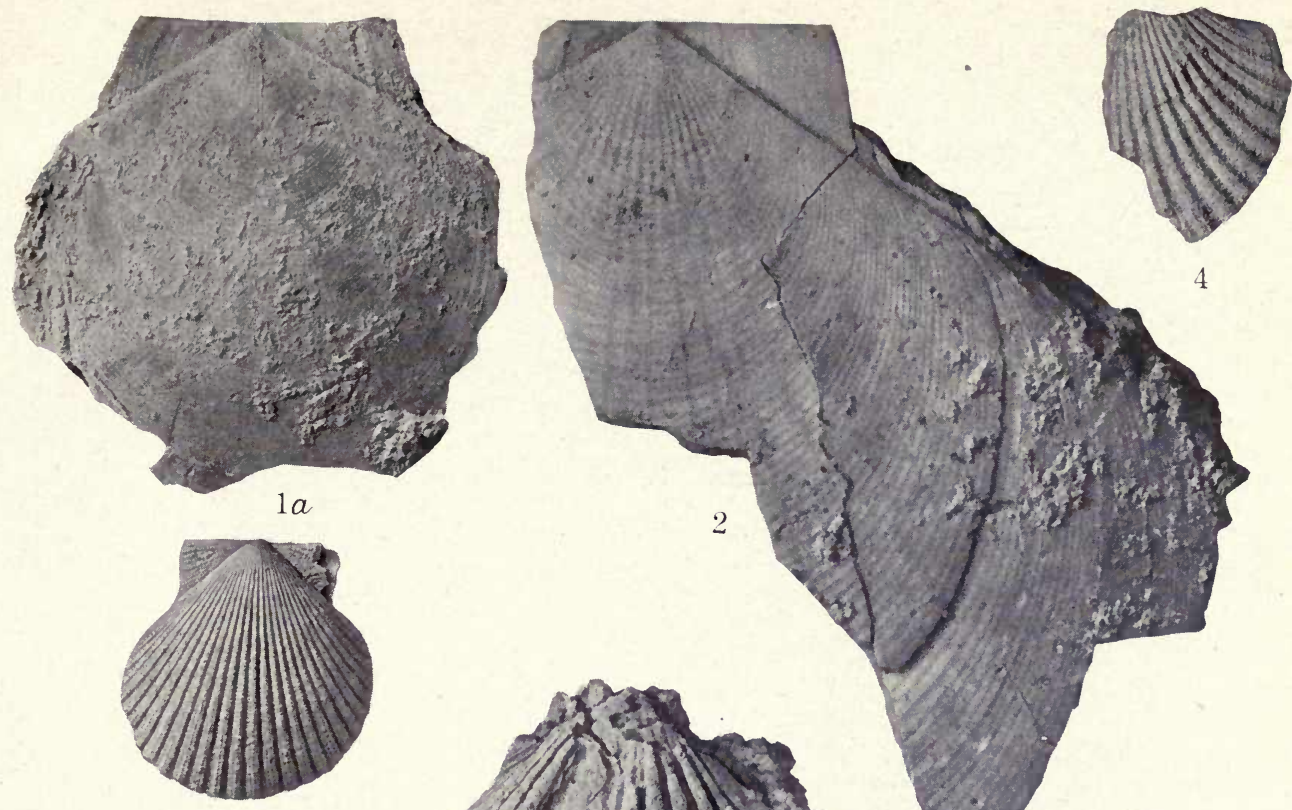

$8 a$

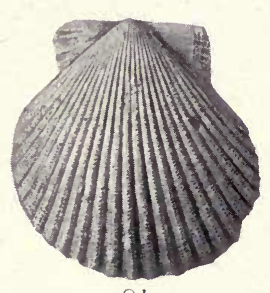

$8 b$

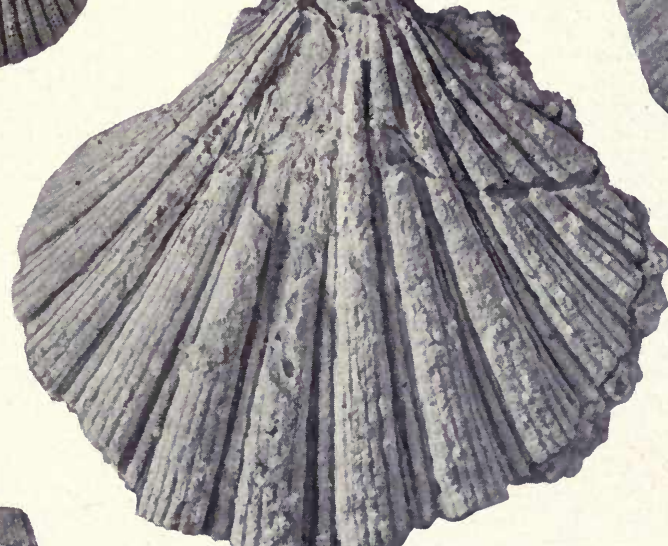

5
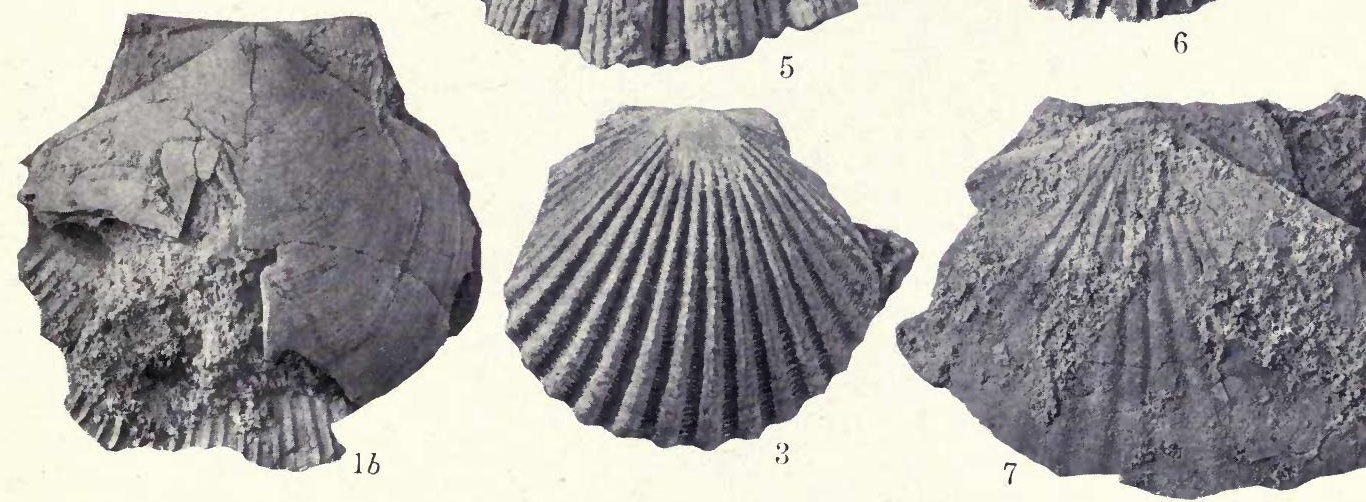

COOKE
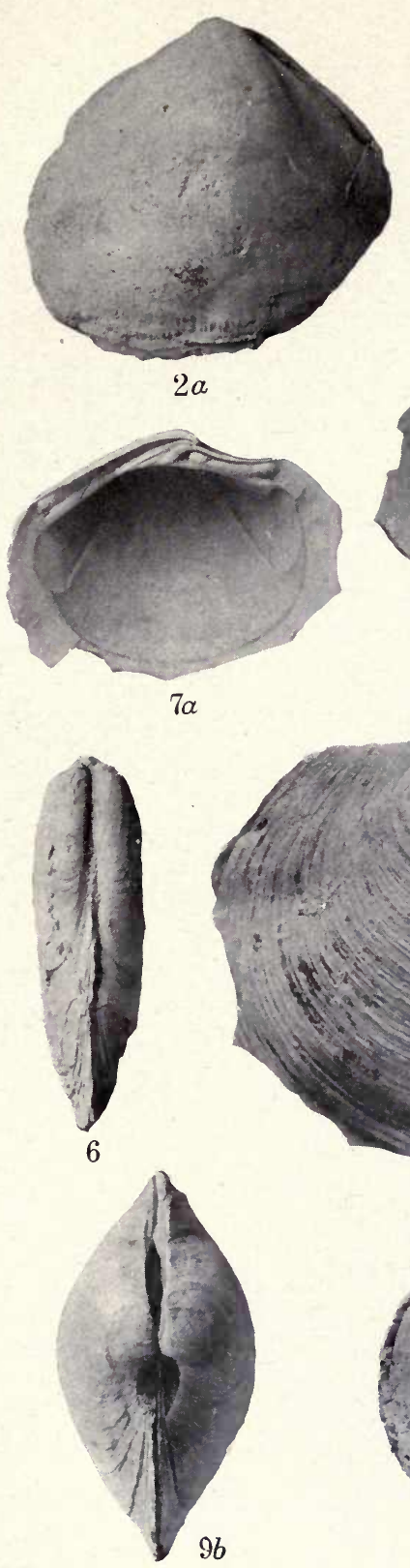

$\left.4 x^{1}\right)^{2}$
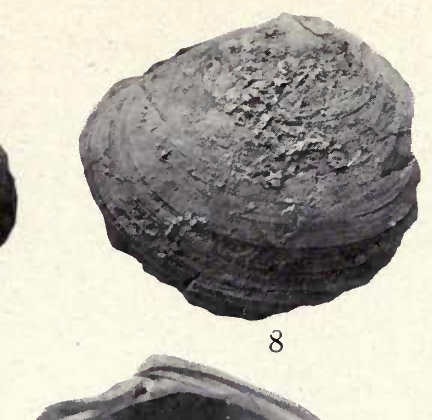

$2 b$
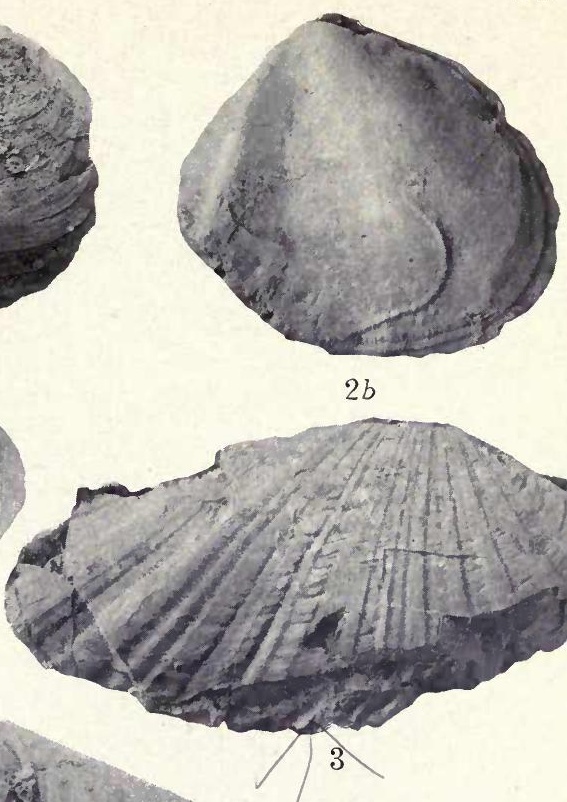

3

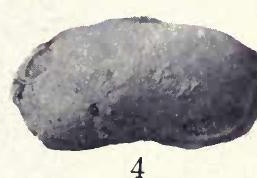

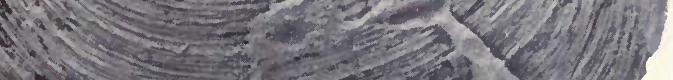
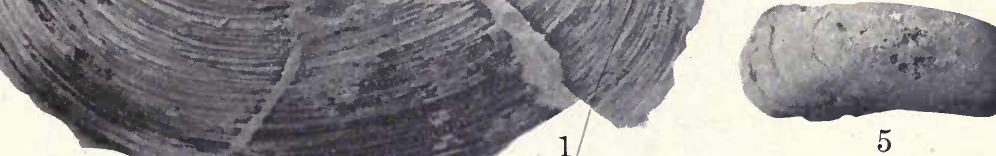

5
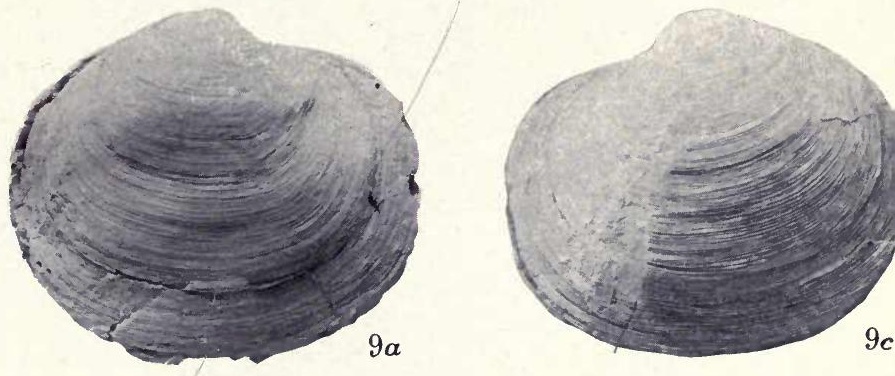

COOKE

PLATE 15
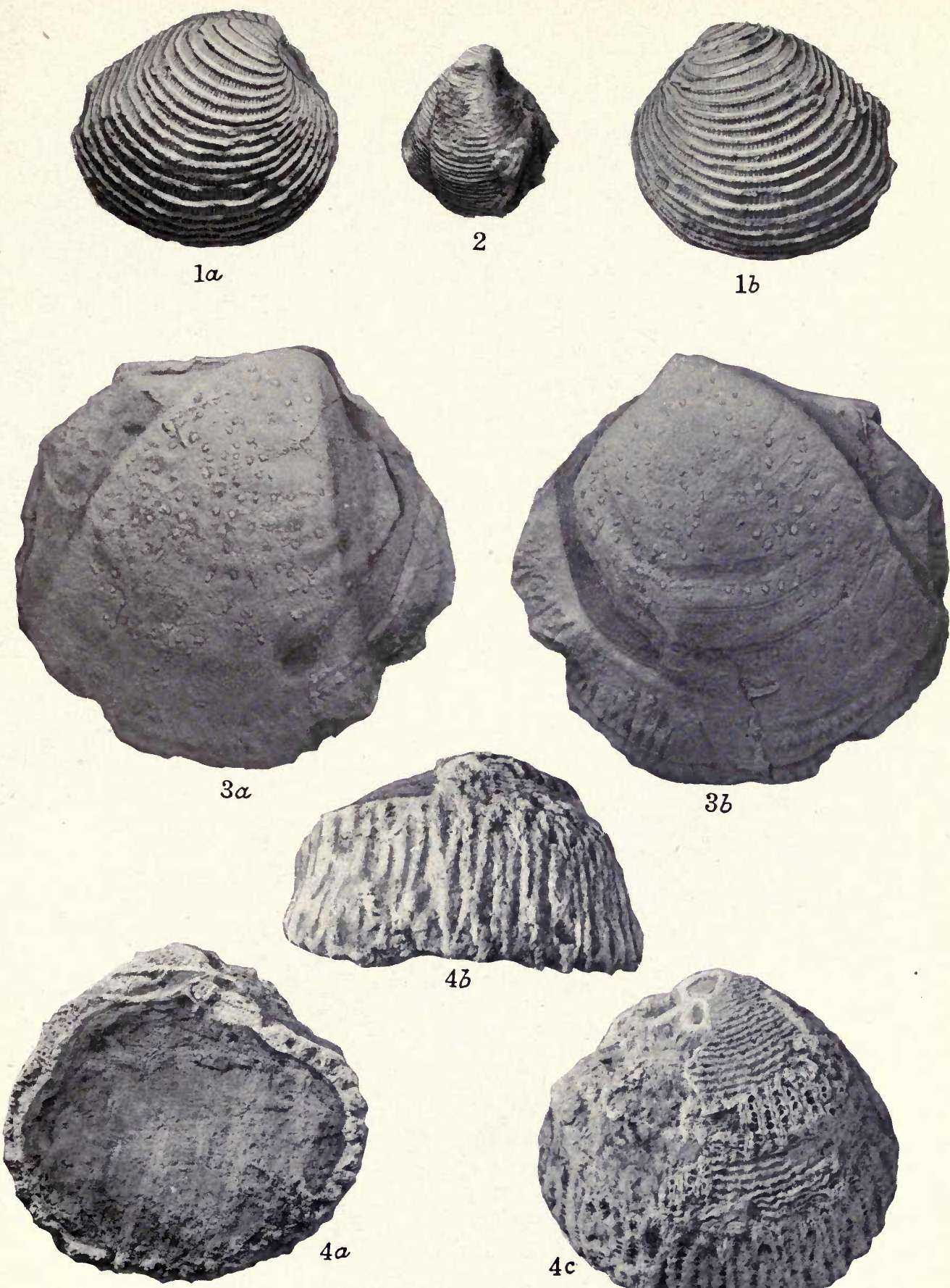

36
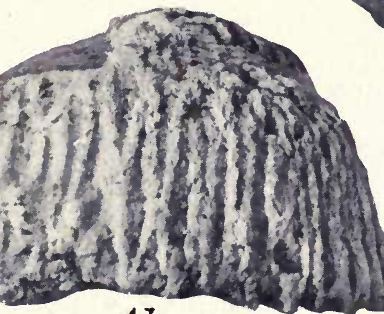

43

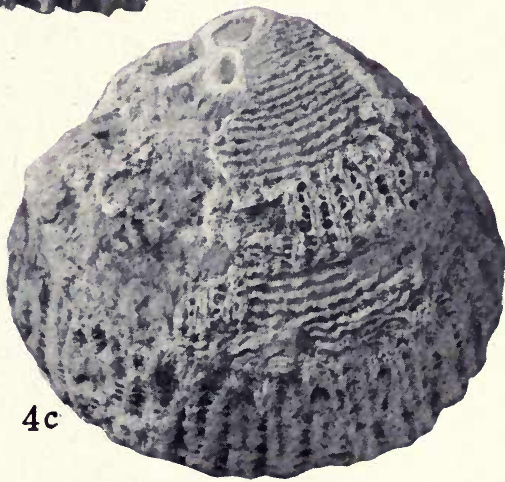



COOKE
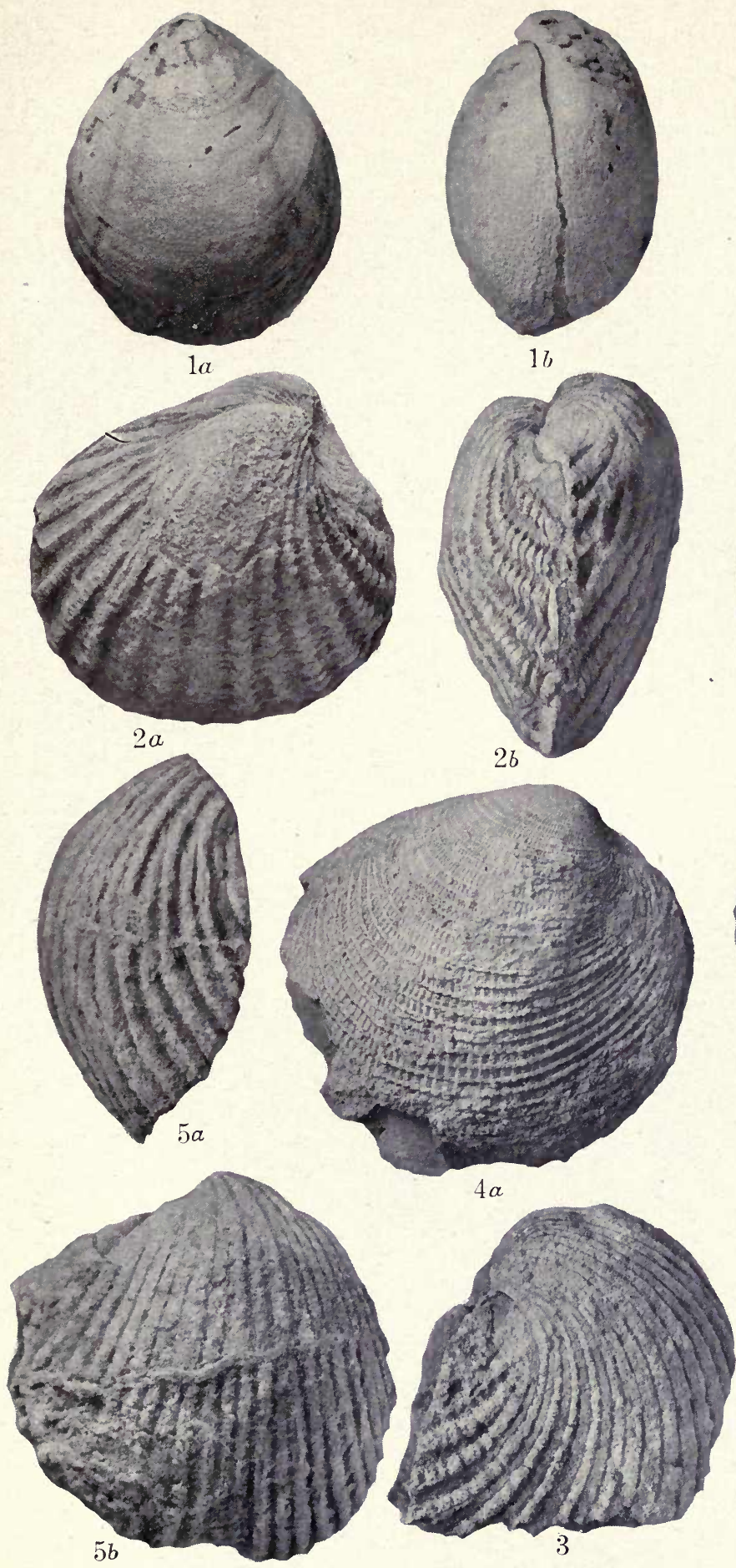

PLATE 16
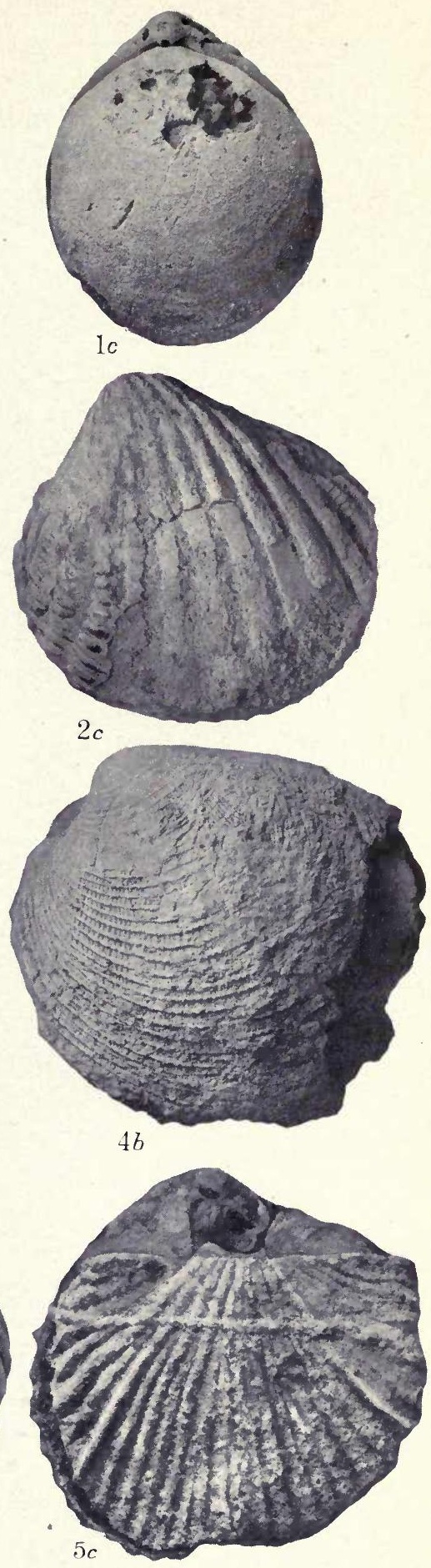

V.

WEST INDIAN TERTIARY DECAPOD CRUSTACEANS.

By Mary J. Rathbun.

With nine plates. 


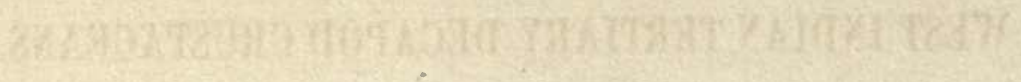

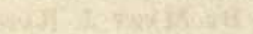

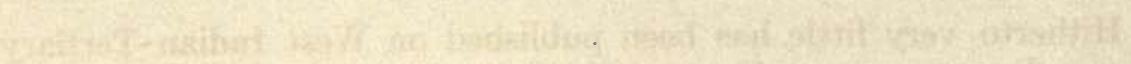

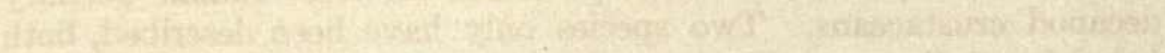

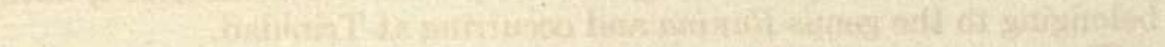

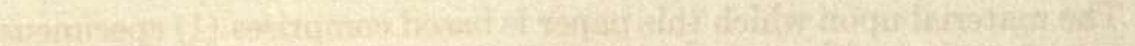
ax.

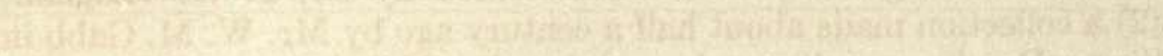

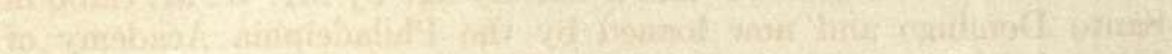

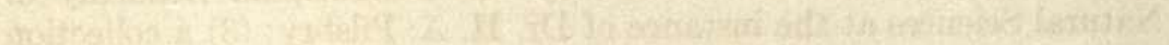

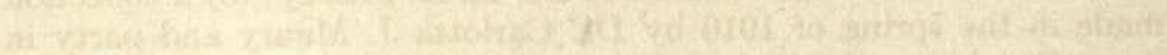

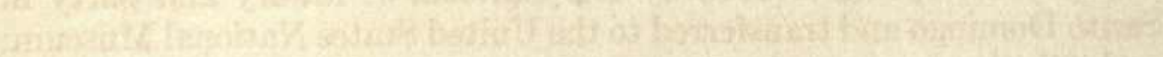

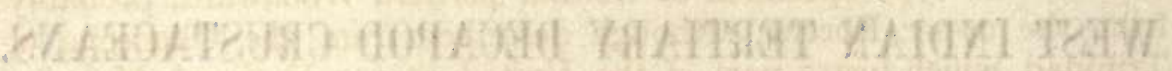

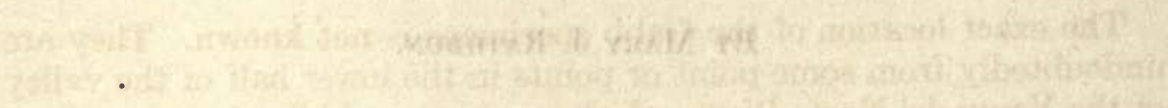

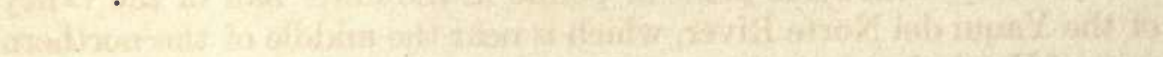

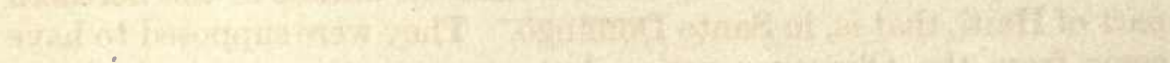

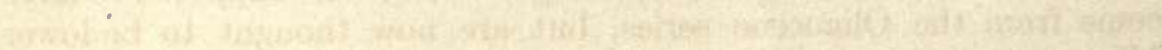

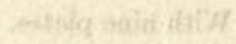

thatcistext

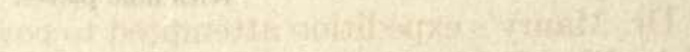




\section{WEST INDIAN TERTIARY DECAPOD CRUSTACEANS.}

By Mary J. Rathbun.

Hitherto very little has been published on West Indian Tertiary decapod crustaceans. Two species only have been described, both belonging to the genus Ranina and occurring at Trinidad.

The material upon which this paper is based comprises (1) specimens obtained at Anguilla and St. Bartholomew by Dr. T. W. Vaughan; (2) a collection made about half a century ago by Mr. W. M. Gabb in Santo Domingo and now loaned by the Philadelphia Academy of Natural Sciences at the instance of Dr. H. A. Pilsbry; (3) a collection made in the spring of 1916 by Dr. Carlotta J. Maury and party in Santo Domingo and transferred to the United States National Museum; and (4) the type specimen of Ranina porifera Woodward, probably from the upper Eocene, although described from the Oligocene of Trinidad, which forms part of the United States National Museum collection.

The exact location of the Gabb specimens is not known. They are undoubtedly from some point or points in the lower half of the valley of the Yaqui del Norte River, which is near the middle of the northern part of Haiti, that is, in Santo Domingo. They were supposed to have come from the Oligocene series, but are now thought to be lower Miocene.

Dr. Maury's expedition attempted to cover the same ground as that visited by Gabb. Crustaceans were found in two spots and of these only one species was taken also by Gabb. Aside from Petrochirus inequalis from the Amina River, the specimens came from "Bluff No. 3," which is near Cercado, on the Mao River, one of the southern tributaries of the Yaqui River.

The bluff, according to Dr. Maury, is several hundred feet high, but the specimens were all obtained fairly near the base, not more than 30 to 50 feet above the river. The horizon is thought by Dr. Vaughan to be lower Miocene, but may be upper Oligocene. The specimens were almost entirely fingers or other small fragments to many of which it is inadvisable to assign even a generic name.

No species is common to the Vaughan and Santo Domingo collections, and the only genus represented in both is Callianassa. On the other hand, Callinectes declivis has been found in Costa Rica as well as Santo Domingo and is described in my bulletin on Panama fossils. ${ }^{1}$

${ }^{1}$ Bull. U. S. Nat. Mus. No. 103, p. 162, pl. 66, figs. 1-3, 1918. 
Two of the Santo Domingan species are thought to be the same as Recent species, viz, Calappa flammea and Cycloes bairdii, the first also from the Pleistocene of Panama, as noted in the above-mentioned bulletin.

\section{LIST OF WEST INDIAN TERTIARY DECAPODA.}

Family Cragonidæ, gen. and sp. indet., Santo Domingo, lower Miocene (Maury).

Family Eryonidæ, gen. and sp. indet., Santo Domingo, lower Miocene (Maury).

Callianassa anguillensis, n. sp., Anguilla, Oligocene (Vaughan).

latidigita, n. sp., Santo Domingo, lower Miocene (Maury). pellucida, n. sp., Anguilla, Oligocene (Vaughan).

miocenica, n. sp., Santo Domingo, probably lower Miocene (Gabb).

Family Paguridæ, gen. and sp. indet., Santo Domingo, lower Miocene (Maury).

Petrochirus inequalis, n. sp., Santo Domingo, lower Miocene (Maury).

Ranina porifera Woodward, Trinidad, probably upper Eocene.

cuspidata Guppy, Trinidad, "lower Miocene."

Lyreidus fastigatus, n. sp., Anguilla, Oligocene (Vaughan).

Calappa flammea (Herbst), Santo Domingo, lower Miocene (Maury).

Calappella (?) sp., Santo Domingo, lower Miocene (Maury).

Cycloes bairdii Stimpson, Santo Domingo, lower Miocene (Maury).

Persephona prepunctata, n. sp., Santo Domingo, lower Miocene (Maury).

Scylla costata, n. sp., Santo Domingo, probably lower Miocene (Gabb).

Portunus gabbi, n. sp., Santo Domingo, lower Miocene (Gabb and Maury).

Portunus tenuis, n. sp., Santo Domingo, lower Miocene (Maury).

Portunus, sp. indet., Santo Domingo, lower Miocene (Maury).

Callinectes declivis Rathbun, Santo Domingo, lower Miocene (Maury).

Callinectes, sp. indet., Santo Domingo, lower Miocene (Maury).

Podophthalmus domingensis, n. sp., Santo Domingo, probably lower Miocene (Gabb).

Zanthopsis bartolomæensis, n. sp., St. Bartholomew, Eocene (Vaughan).

Pilumnus subequus, n. sp., Santo Domingo, lower Miocene (Maury).

Archæopilumnus cælatus, gen. and sp. new, Santo Domingo, probably lower Miocene (Gabb). Panopeus, sp. indet., Santo Domingo, lower Miocene (Maury).

Family Xanthidæ, gen. and sp. indet., Santo Domingo, lower Miocene (Maury).

Sandomingia yaquiensis, gen. and sp. new, Santo Domingo, probably lower Miocene (Gabb).

Parthenope (Platylambrus) obscura, n. sp., Santo Domingo, lower Miocene (Maury).

Parthenope, sp. indet., Santo Domingo, lower Miocene (Maury).

Mesorhœa mauryæ, n. sp., Santo Domingo, lower Miocene (Maury). 


\section{NOTES ON THE GENERA REPRESENTED.}

The genus Callianassa ${ }^{1}$ ranges from the Jurassic era to the present day and contains very numerous species, fossil ${ }^{2}$ and Recent, distributed in both hemispheres.

Petrochirus ${ }^{3}$ occurs in the waters on both sides of tropical America, and in the upper Tertiary of Panama.

Ranina ${ }^{4}$ is known from more than a dozen species distributed from the Cretaceous to Recent, the fossil forms ${ }^{5}$ ranging from central Europe to Japan, and occurring isolated in Trinidad. Only one species is now living and that is confined to the Indo-Pacific region.

Lyreidus ${ }^{6}$ has been found in the Tertiary of Piedmont, Italy. Of its Recent species, one $(L \text {. bairdii })^{7}$ inhabits deep water off the Atlantic and Gulf coasts of North America, while three others (L. tridentatus, ${ }^{8}$ $L$. elongatus, ${ }^{9}$ and $L$. channeri ${ }^{10}$ ) represent the Indo-Pacific region, the latter inhabiting the Indian Ocean at a depth of 200 to 400 fathoms.

Calappa $a^{11}$ has a range from Eocene to Recent (Zittel).

Calappella ${ }^{12}$ Rathbun is known from the Oligocene of Panama.

Cycloes $^{13}$ up to now known only as Recent on both sides of the American continent, the Bermudas, and the Indo-Pacific.

Persephona ${ }^{14}$ hitherto recorded from the post-Tertiary of Celebes ${ }^{15}$ (as Myra) and widely distributed in the warmer waters of the globe.

Scylla, ${ }^{16}$ a genus of swimming crabs, is known at the present time from one living species only, which is widely distributed throughout the Indo-Pacific region. This species has also been found fossil on the coasts of Asia between the Red Sea and Japan, and in the Philippines; also in the island of Malta, at which place it is reported from the Oligocene or older Miocene. A second species, S. michelini, ${ }^{17}$ occurs in the Miocene of Anjou.

Portunus Weber ${ }^{18}$ ( = Neptunus de $\operatorname{Haan}^{19}$ ), a comprehensive genus, makes its appearance in the Eocene and is represented in the recent fauna also by numerous species in all temperate and tropical seas.

\footnotetext{
${ }^{1}$ Leach, Edin. Encyc., vol. 7, p. 400, 1814.

2 See Böhm, Monatsber. deutsch. geol. Gesell., vol. 63, pp. 42-46, 1911.

${ }^{3}$ Stimpson, Proc. Acad. Nat. Sci. Philadelphia, vol. 10, p. 233 [71], 1858.

1 Lamarck, Syst. Anim. sans Vert., p. 156, 1801.

' See Woodward, Quart. Jour. Geol. Soc. London, vol. 22, p. 591, 1866.

- De Haan, Fauna Japon., Crust., p. 138, 1841.

7 Smith, Proc. U. S. Nat. Mus., vol. 3, p. $420,1881$.

${ }^{8}$ De Haan, Fauna Japon., Crust., p. 140, plate 35, fig. 6, 1841.

Miers, Proc. Zool. Soc. London, p. 46, 1879.

${ }^{10}$ Wood-Mason, Proc. Asiat. Soc. Bengal, Aug. 1885 (issued Nov. 2, 1885), p. 104.

1 Weber, Nomenclator entomologicus, p. 92, 1795.

12 Bull. U. S. Nat. Mus. No. 103, p. 157, 1918.

${ }^{13}$ De Haan, Fauna Japon., Crust., pp. 67 and 68, 1837.

14 Leach, Zool. Misc., vol. 3, pp. 18 and $22,1817$.

15 De Man, Samml. Geol. Reichs-Mus. Leiden, ser. 1, vol. 7, p. 276, 1904.

${ }^{16}$ De Haan, Fauna Japon., Crust., pp. 3 and 11, 1833.

17 A. Milne-Edwards, Ann. Sci. Nat., ser. 4, vol. 14, p. 136, plate 3, figs. 3, 3a, 1861.

18 Nomenclator entomologicus, p. 93, 1795.

19 Fauna Japon., Crust., pp. 3 and 7, 1833.
} 
Callinectes, ${ }^{1}$ the genus of our common edible blue crab, is abundant in America and West Africa, rarer in the Indo-Pacific, and has been found fossil in the Virginia Miocene.

Recent Podophthalmus ${ }^{2}$ inhabit the Indo-Pacific region and one of the two living species occurs also in the post-Tertiary of Celebes and Java. Other fossil species placed in this genus have been later removed to different genera.

Zanthopsis ${ }^{3}$ is wholly a fossil genus and contains various species, beginning in the Cretaceous and distributed in Europe and Brazil.

Pilumnus ${ }^{4}$ is a Recent genus containing about 150 species and flourishes in nearly all temperate and tropical waters. It has not before been reported as fossil.

The new genus Archoopilumnus is a near relative of Pilumnus.

Panopeus ${ }^{5}$ is said to occur from the Cretaceous to the present day. It is the principal genus of the mud crabs of our coasts, and occurs rarely in the eastern Atlantic.

The genus Sandomingia is erected for a form allied to the fiddler crabs (Uca =Gelasimus) which to-day have an almost world-wide distribution, especially in warmer regions, and are also found fossil in southern Asia.

Parthenope ( $^{\text {Lambrus }}$ L $^{7}$ is a genus widely distributed in the sea, and dates from the Eocene.

Mesorhoea ${ }^{8}$ is rare in middle America and has not before been found fossil.

\section{NOTES ON THOSE FAMILIES REPRESENTED BY MATERIAL FOR WHICH IT IS IMPOSSIBLE TO DESIGNATE A GENUS.}

The Cragonidæ originate in the Jurassic and are very abundant today. The telson described below is characteristic of the family, but of no one genus known.

The Eryonidæ are among the oldest decapods, going back to the Triassic. The West Indian specimen has the curious curved and bent form of the ischium of the large cheliped in that family.

\section{RELATIONS OF THE WEST INDIAN FAUNA.}

The greater number of the genera and families represented in the West Indian Tertiary fauna have to-day a wide distribution, as also have the genera most closely akin to the new or purely fossil genera, as Calappella, Archooopilumnus, Sandomingia, and Zanthopsis. A few

\footnotetext{
${ }^{1}$ Stimpson, Ann. Lyc. Nat. Hist. New York, vol. 7, p. 220, 1860.

2 Lamarck, Syst. Anim. sans Vert., p. 152, 1801.

'M'Coy, Ann. Mag. Nat. Hist., ser. 2, vol. 4, p. $162,1849$.

Leach, Trans. Linn. Soc. London, vol. 11, pp. 309 and 321, 1815.

- Milne-Edwards, Hist. Nat. Crust., vol. 1, p. 403, 1834.

- Weber, Nomenclator entomologicus, p. 92, 1795.

7 Leach, Trans. Linn. Soc. London, vol. 11, pp. 308 and 310, 1815.

${ }^{3}$ Stimpson, Bull. Mus. Comp. Zoöl., vol. 2, p. 135, 1871.
} 
other genera are distinctively American, viz, Petrochirus, Panopeus (rarely eastern Atlantic), and Mesorhoea. Otherwise the West Indian fossil decapods have a strong affinity with the present Indo-Pacific fauna, as evidenced by Ranina, Scylla (both Recent Indo-Pacific genera but fossil in Europe), Podophthalmus (wholly Indo-Pacific), and Lyreidus (typically and chiefly Indo-Pacific, partly western Atlantic, and fossil in Europe). Moreover, Portunus gabbi, described below, is related to recent Indo-Pacific species more than to those now living in the West Indies.

\section{DESCRIPTION OF THE MATERIAL.}

Order DECAPODA.

Suborder NATANTIA.

Tribe CARIDES.

Superfamily CRAGONOIDA.

Family CRAGONIDAE.

Genus and species indeterminable.

(Plate 9, Figure 3.)

Material.-The telson of a single specimen, from the Yaqui Valley at Cercado de Mao (Bluff 3), Santo Domingo; lower Miocene; C. J. Maury, collector; 1916.

The following is a description of this specimen:

Telson high, narrow, horizontal; tapering for its proximal half, then the sides parallel, tip broken off. On either side a deep groove running the whole length; above, three ridges separated for the basal third by two deep grooves; not far from the base a fine groove begins on the median ridge and is continued nearly to the tip; it divides this ridge in two, each half further on uniting with the submedian ridge of its side; on the outer side of each submedian ridge near its base there is a short ridge, partly visible in dorsal view. Below, the telson is broadly and deeply concave, the concavity narrowing along the middle. All the ridges are smoothly rounded.

Relationship.-This specimen is not referable to any known genus, as, while the general appearance is that of a cragonid, the grooves of the telson are much deeper than in any of the living forms.

\section{Suborder REPTANTIA.}

Tribe PALINURA.

Superfamily ERYONIDEA.

Family ERYONIDE.

Genus and species indeterminable.

(Plate 9, Figure 4.)

Material.-A fragment, representing seemingly the greater part of the ischium of the right cheliped of the first pair, from the Yaqui Valley at Cercado de Mao (Bluff 3), Santo Domingo; lower Miocene; C. J. Maury, collector; 1916. 
Description.-This piece has the typical Eryonid form of the ischium of the first cheliped, that is, it is much flattened, distally widened, and proximally curved. While the segment is commonly unarmed, the fossil joint has a row of irregular and immovable spines along its inner margin; it has also numerous scattered punctæ arranged partially in lines.

Tribe ANOMURA.

Superfamily THALASSINIDEA.

Family CALLIANASSIDE.

Genus CALLIANASSA Leach, 1814.

Callianassa anguillensis, new species.

(Plate 1, Figures 1 to 7.)

Type locality.-Anguilla: Crocus Bay, southwestern shore; from lowest 10 to 15 feet of fossiliferous marls;Anguilla formation; Oligocene series; T. W. Vaughan, collector; March 7, 1914; 6965; L. I. $100 a$ (1914).

Holotype.-One right manus and base of immovable finger. Cat. No. 166941 , U. S. N. M.

Additional material.-One right manus (paratype $a$ ) and a separate piece of a finger (paratype $b$ ) from southwestern side of Crocus Bay, Anguilla; 30 to 50 feet above sea-level; Anguilla formation; T. W. Vaughan, collector; March 4, 1914; 6966; L. I. 100 b (1914). Cat. No. 166942 , U. S. N. M.

A right (paratype $c$ ) and a left manus (paratype $d$ ) and a piece of a finger (paratype $e$ ), 3 specimens in all, from southwestern side of Crocus Bay, Anguilla; Anguilla formation; T. W. Vaughan, collector, March 1914; 6894; L. I. 100 (1914). Cat. No. 166943, U. S. N. M.

The following is a description of the holotype:

The specimen is embedded in the rock so that the lower half of the outer surface is exposed and a portion of the upper margin. Length through middle of palm, $18.6 \mathrm{~mm}$., width at posterior third, $16 \mathrm{~mm}$. Lower margin a thin, raised rim set off by a groove. Inside and a little below the rim may be seen a row of rather large sockets opening distally. The margin is sinuous, deepest near the proximal third, whence it rounds convexly upwards toward the wrist and forms a gently sinuous curve to the base of the fixed finger. The surface of the palm is partially covered with blister granules, which are large just behind the finger and get smaller, lower, and fewer toward the proximal end; they are separated by a narrow, smooth area from a few granules on the distal margin along the cavity separating the fingers. Among the granules there are a few punctæ or sockets of which 8 widely spaced ones form a row above the lower margin. The marginal rim soon fades out on the finger; the upper border of the finger is edged with flattened granules. The surface is chalky white. The white layer is broken off of the upper marginal portion of the palm; the surface thus exposed is blunt and transversely rugose, and on the inner side just below the margin and $3.7 \mathrm{~mm}$. from the distal end there is a curved tubercle, pointing forward; also in the same line a spine at the distal extremity. 


\section{The following is a description of the paratypes:}

Paratype $a$, right manus, No. 6966. This is free from the matrix and is much worn and incomplete at the ends, width at posterior third, $17.4 \mathrm{~mm}$. It agrees with the holotype as far as the characters are preserved. The shape is similar, also the thin lower edge with a row of sockets just inside, the granulation of the lower part of the outer surface, and the single tubercle just below and within the upper margin, and, in this instance, $5 \mathrm{~mm}$. behind the distal end.

Paratype $b$, finger, No. 6966. Lacks the tip and proximal end and is embedded in rock with its concave surface uppermost. Chalky white. Crosssection triangulate.

Paratypes $c$ and $d$, right and left manus, No. 6894. These specimens are too bruised to refer definitely to any species. They have the general shape of the holotype of $C$. anguillensis. The left manus has the thin lower and the thick rounded upper margin, the latter with the submarginal tubercle distal to the middle, but not so near the forward end as in the holotype; it lacks details of granulation, sockets, etc. The right manus is even less adequately preserved.

Paratype $e$, finger, No. 6894. The distal portion of a finger embedded in rock, with convex surface partly exposed, should probably be referred here.

Callianassa latidigita, new species.

(Plate 9, Figures 10 and 11.)

Type locality. - The Yaqui Valley at Cercado de Mao (Bluff 3), Santo Domingo; lower Miocene; C. J. Maury, collector; 1916.

Material.-A movable and an immovable finger of the left chela; the latter is the holotype. Cat. No. 324470 , U. S. N. M.

This species has granulation on the palm at the base of the immovable finger similar to that in $C$. anguillensis (compare plate 1, fig. 1, with plate 9 , fig. 11); the finger itself is, however, broader at base and is subtriangular, while the finger of anguillensis tapers very gradually at base. The inferior, marginal rim is continued further toward the tip in the Cercado specimen, while the upper edge is furnished near the base with two shallow lobes which are lacking in anguillensis. The dactylus has the same general shape in the two forms, but both specimens are too incomplete for close comparison.

Callianassa pellucida, new species.

(Plate 1, Figures 8 to 13 .)

Type locality.-Anguilla: Crocus Bay, from bluff on southwestern side; uppermost horizon, 125 feet above sea-level; Anguilla formation; Oligocene series; T. W. Vaughan, collector; March 4, 1914; 6967; L. I. $100 c$ (1914). One left movable finger (holotype); a portion of each of two right palms of very different sizes (paratypes).

Holotype and paratypes.-Cat. No. 166944, U. S. N. M.

The following is a description of the holotype:

The shape of the entire finger is shown, but the outer layer is almost all lacking. Upper margin arched, tip acute and strongly bent down; lower margin straight except near the tip and at the proximal end, where it is hol- 
lowed out in a broad, shallow sinus. The general shape is subcylindrical, distally tapering, but the lower edge of the outer surface is acute. There are a few scattered granules or small tubercles, but it is impossible to tell how much these affected the outer shell: on the outer surface above the lower edge there is a row of 4 distant granules; 4 near the proximal end of the upper surface, and 1 near the distal end; 1 on the inner surface behind the middle.

Length, $20.4 \mathrm{~mm}$.; greatest width, $5.3 \mathrm{~mm}$.; thickness, $4.1 \mathrm{~mm}$.

The two palms (paratypes) are too incomplete to show their proportions. The lower edge is thin, translucent (to which the specific name alludes), in the larger specimen (paratype $a$ ) slightly sinuous, that is, rounded up at the proximal end and bending down toward the fingers; below the true edge of the palm project the bases of sockets ranged in a row on the inner surface; there are about 17 of these sockets in the larger specimen. The cross-section at the base of the finger has the shape of a diamond very elongate below the angles (plate 1, fig. 10).

Callianassa miocenica, new species.

(Plate 2, Figures 1 to 6.)

Type locality.-Lower half of the valley of the Yaqui del Norte River, in the northern part of Santo Domingo, Haiti; probably lower Miocene; W. M. Gabb, collector.

Holotype.-Ieft manus of large cheliped. Cat. No. 2264, Mus. Phila. Acad. Nat. Sci.

Measurements.-Length of manus measured from sinus between fingers, 21.2; width of manus near proximal end, 17.4; width of manus near distal end, 15.2; greatest thickness of manus, $7 \mathrm{~mm}$.

The following is a description of the left manus of this species:

The upper margin is straight and at right angles to the proximal end, while the lower margin is slightly convex and oblique, being inclined upward toward the distal end and inward toward the proximal end. Outer surface very convex from top to bottom, but from end to end flat in the middle and bent inward at the ends. On the outer surface are 3 large pits far apart in a line below the middle; the pits increase in size distally, the largest one being near the articulation of the dactylus; one pit higher up and midway of the length of the segment. Upper margin subacute in its proximal two-thirds; lower margin broken away. Inner surface uneven, concave in the lower distal portion; surface covered with small pits, visible without a lens, scanty near the distal end. Here there is a transverse curved line (concave forward) of 8 granules, just below the middle; the margin overlapping the dactylus is bordered with 15 tuberculiform teeth, the lowermost of which is the largest and much swollen and lies below the dactylus. Ten similar small teeth are visible on the distal end of the outer surface. Near the upper edge are 2 rows of large pits; one row consists of 5 pits and is wholly on the inner surface, bending downward distally; the other row shows 3 pits in a straight line which is slightly oblique.

Relationships.-From C. anguillensis this species differs in the smooth (non-granulate) surface of the manus; from $C$. pellucida in the straighter (viewed from below only) lower edge of the manus. 
Superfamily PAGURIDEA.

Family PAGURIDE.

Genus and species indeterminable.

(Plate 9, Figures 6 and 7.)

Material.-Dactylus of left cheliped, from the Yaqui Valley at Cercado de Mao (Bluff 3), Santo Domingo; lower Miocene; C. J. Maury, collector; 1916.

Description. - The upper surface of the dactylus is rounded from side to side, while the lower surface is narrower and flat and the inner surface oblique and sinuous (from end to end), the two surfaces separated by a line of tubercles. Upper surface covered with unequal granules, except near the prehensile edge; thick outer edge also granulate; a few granules on flat surface; oblique surface smooth. Eight prehensile teeth with brown tips; a shallow sinus near proximal end of margin. Tip of finger broken off, but there is no evidence that the finger is excavated at the tip.

While this is a left dactylus, it is not clear whether it belongs to a major or a minor cheliped.

\section{Genus PETROCHIRUS Stimpson, 1858.}

Petrochirus inequalis, new species.

(Plate 9, Figures 13 to 15.)

Type locality.-The Amina River, Yaqui Valley, Santo Domingo; lower Miocene; C. J. Maury, collector; May 22, 1916.

Material.-A pair of chelæ partially embedded. Cat. No. 324467, U. S. N. M.

Description.-The proximal end of both palms is lacking. The chelæ are very unequal, a similar cross-section of the palm of each showing that the width of the palm is two-thirds as great in the smaller as in the larger chela, while the inequality in the thickness of the two may be even more. Fingers of large chela broad at base, tapering gradually toward the tips, excepting that the dactylus has on its outer margin a sinus distad of the middle; measured on the prehensile edge, the dactylus is over twice as long as basal width, while the immovable finger is less than twice as long as basal width. The tip of the dactylus folds under the immovable finger and is apparently not so long. Fingers blunt-pointed. Most of the tubercles of the fingers are broken off, leaving the tessellated background formed by their crowded, many-sided bases. The tubercles which remain, especially those on the underside of the palm, trend slightly distad, each surrounded anteriorly by a few small tubercles, and the larger ones separated from one another by tubercles of medium size. Tubercles conical, tip subacute, defined by a line from the basal portion and easily broken off.

The fingers of the small chela as they stand scarcely reach beyond the proximal third of the large dactylus, but the chelæ may not be in their true relative position. The tubercles are similar to, but lower than, those of the larger chela.

Relationships. - This species has a smaller left chela than any Petrochirus yet described. The fingers of the right chela are exceptionally 
long. In its ornamentation it is nearest $P$. californiensis Bouvier ${ }^{1}$ (Lower California to Ecuador), but in that species the tubercles have broadly rounded knobs at the summit, instead of pointed tips as in $P$. inequalis.

Tribe BRACHYURA.

Subtribe OXYSTOMATA.

Family RANINID $A$.

Genus RANINA Lamarck, I80r.

Ranina porifera Woodward.

Ranina porifera Woodward, in Guppy, Quart. Jour. Geol. Soc. London, vol. 22, p. 572, plate 26, fig. 18, 1866; Quart. Jour. Geol. Soc. London, vol. 22, p. 591, 1866.

Type locality.-Trinidad; San Fernando beds; geologic age not positively known, probably upper Eocene.

Holotype-Carapace without appendages. Cat. No. 115405 , U. S. N. M.

Ranina cuspidata Guppy.

Ranina cuspidata Guppy, Bull. Agri. Dept. Trinidad, p. 5, plate, fig. 1, 1909; Agricultural Society of Trinidad and Tobago, Paper No. 440, p. 14, 1911.

Type locality.-Trinidad; Machipur, near Montserrat, in the Tamana district; "lower Miocene".

\section{Genus LYREIDUS de Haan, 1841.}

Lyreidus fastigatus, new species.

(Plate 3; Figure 1.)

Type locality.-Anguilla: Crocus Bay, southwestern side; 30 to 50 feet above sea-level; Anguilla formation; Oligocene series; T. W. Vaughan, collector; March 4, 1914; 6966; L. I. 100 b (1914).

Holotype.-Carpus joint of left cheliped. Cat. No. 166940, U. S. N. M.

The following is a description of this species:

The carpus is suboblong, about $11.6 \mathrm{~mm}$. long by $5.6 \mathrm{~mm}$. wide. The surface is crossed transversely by fine rugæ. A blunt ridge runs longitudinally through the middle, following the axis of the segment, that is, slightly curved, the concavity of the curve facing the left or outer side; this ridge is interrupted at its distal end by a tubercle. On the inner margin at about its middle there is a slender, curved spine standing well out from the segment; further back at about the posterior fourth there is a smaller spine, broken off at its base. Near the posterior end of the left side of the dorsal surface there is a tubercle, or, it may be, a spine, the top being broken off. It is difficult to say anything further of the details, as the margin is considerably obscured; the segment appears to be strongly produced at its inner distal angle, and the adjacent inner margin shows a small tooth.

Other species of the genus.-Crema ${ }^{2}$ has described a Lyreidus, $L$. paronœ, from the Tertiary of Piedmont. He had, however, no part of the chelipeds.

1 Bull. Mus. Hist. Nat., Paris, p. 6, 1895.

${ }^{2}$ Atti R. Accad. Sci. Torino, vol. 30, p. 671, plate, fig. 11 (carapace), 1895. 
Of recent species of Lyreidus, one, $L$. bairdii Smith $^{1}$ has been found in deep water off the Atlantic and Gulf coasts of the United States. Its carpus is less elongate and lacks the longitudinal ridge present in our fossil form; the principal spine of the inner margin is also further forward.

\title{
Family CALAPPIDEE. Genus CALAPPA Weber, 1795 . Calappa flammea (Herbst).
}

Cancer flammeus Herbst, Natur. Krabben u. Krebse, vol. 2, plate 40, fig. 2, 1794; vol. 3, pt. 3, p. 19, 1803.

Material.-Three dactyls of right or major chelæ; also a specimen showing the proximal half of both fingers of the right chela and their attachment to each other. From the Yaqui Valley at Cercado de Mao (Bluff 3), Santo Domingo; lower Miocene; C. J. Maury, collector; 1916.

Range.-Recent specimens range from North Carolina, or occasionally farther north, to Colombia and Venezuela; also at Bermudas and Cape of Good Hope. Fossil fingers have been taken in the Pleistocene of Panama.

\author{
Genus CALAPPELLA Rathbun, 1918. \\ Calappella (?), species. \\ (Plate 9, Figure 12.)
}

Material.-A piece of the right manus and 4 loose spines, from the Yaqui Valley at Cercado de Mao (Bluff 3), Santo Domingo; lower Miocene; C. J. Maury, collector; 1916.

The following is a description of this species:

The specimen figured is a fragment showing a portion of the outer and of the under surface broken from the middle of the right manus of a species allied to Calappa. The specimen is rather closely granulated except above, and bears two tubercles, the larger and more distad conical, the smaller one more obtuse at end. Four single, elongate-conical, slightly curved spines, from 3 to 4.5 $\mathrm{mm}$. long, are thought to belong to the same species; two of the spines belong at an articulation, probably at the lower distal angle of the merus of the chelipeds (right and left); another spine appears to have come from the proximal end of the manus.

Relationship.-The genus Calappella was erected for a species from the Oligocene of Panama. The type specimen shows only the carapace, which is armed with elongate, curved spines. On account of the spines the Santo Domingan fragments are referred tentatively to the same genus.

\section{Genus CYCLOES de Haan, I837. \\ Cycloes bairdii Stimpson.}

(Plate 9, Figure 8.)

Cyclois bairdii Stimpson, Ann. Lyc. Nat. Hist. New York, vol. 7, p. 237, 1860.

Material.-The lower distal portion of the outer surface of the left or secondary manus, with propodal finger. So far as can be judged

${ }^{1}$ Proc. U. S. Nat. Mus., vol. 3, p. 420, 1880. 
from this small fragment, it is the same as Recent specimens. From the Yaqui Valley at Cercado de Mao (Bluff 3), Santo Domingo; lower Miocene; C. J. Maury, collector; 1916.

Range.-Recent specimens range from Bahamas and west Florida to the West Indies; also Cape St. Lucas, Lower California, to Panama.

Family LEUCOSIIDE.

Genus PERSEPHONA Leach, 1817.

Persephona prepunctata, new species.

(Plate 9, Figure 5.)

Type locality.-The Yaqui Valley at Cercado de Mao (Bluff 3), Santo Domingo; lower Miocene; C. J. Maury, collector; 1916.

Material.-About 30 arm-joints, mostly incomplete. One of the best is made the holotype (Cat. No. 324425 , U. S. N. M.).

Relationships.- In shape these specimens approach the corresponding segments of $P$. punctata (Linnæus) ${ }^{1}$ but the granules are much more numerous and crowded than in punctata, resembling more those of $P$. townsendi (Rathbun), ${ }^{2}$ from the west coast of tropical America.

\section{Subtribe BRACHYGNATHA.}

Superfamily BRACHYRHYNCHA.

Family PORTUNIDE.

Genus SCYLLA de Haan, 1833.

Scylla costata, new species.

(Plates 4 and 5; Plate 6, Figures 3 to 5.)

Type locality.-Lower half of the valley of the Yaqui del Norte River, in the northern part of Santo Domingo, Haiti; probably lower Miocene; W. M. Gabb, collector.

Holotype.-Male. Cat. No. 2267, Mus. Phila. Acad. Nat. Sci.

Measurements.-Length of carapace (approx.) $82 \mathrm{~mm}$.; width of carapace $128 \mathrm{~mm}$; length of propodus of larger cheliped, above, 42 $\mathrm{mm}$.; below (approx.) $111 \mathrm{~mm}$.; height of same $41.3 \mathrm{~mm}$.

Description.-Regions of carapace separated by very shallow depressions; no evidence of transverse, granulate ridges; the outer layer of shell is almost entirely lacking. The margin of the front is embedded in the matrix. Inner edge of orbit raised, marginate; outer tooth large, its outer margin oblique but almost longitudinal. The antero-lateral teeth are probably $\mathbf{9}$ and are alternately large and small, at least the sixth and the eighth are small, the second and the fourth are not visible. The teeth are curved forward at the end; the third, fifth, seventh, and ninth teeth dim nish in basal width in the order named.

Chelipeds very strong, unequal. Three spines are visible on the inner or anterior margin of the merus beyond the edge of the carapace; the most distal one is strong, conical, sharp; the most proximal one is smaller and more

1 Syst. Nat., ed. 10, vol. 1, p. 630, 1758 (part).

2 Mra townsendi Rathbun, Proc. U. S. Nat. Mus., vol. 16, p. 255, 1893. 
slender; no spine visible on outer or posterior margin, but there is a transverse depression, which may indicate a tooth further down, in the matrix. The carpus is short and squarish; spine not visible. The propodus has a very convex lower margin; the manus is costate, having 3 blunt costæ on the outer surface; the middle one is the most prominent, straight, and directed toward the middle of the interdigital sinus, but stops short of it; the upper costa begins at the tooth at the articulation with the carpus, is slightly concave upward, and ends in a distally projecting lobe just above a large protuberance at the lateral articulation with the dactylus; the lower costa begins proximally near the middle costa, from which it gradually diverges and fades out near the middle of the immovable finger. A spine on inner surface near distal end, at least in major chela. On either side of the manus at its articulation with the dactylus there is a large, smooth, rounded protuberance, which is bounded proximally by a deep, narrow furrow; below this protuberance and distal to it there is, on the outer surface at least, a thick, subacute lobe, overlapping the dactylus. The prehensile teeth are very unequal, smoothly rounded, darkcolored; in the larger chela the basal tooth of the dactylus is very large and directed obliquely backward, and the fingers gape moderately.

Only the basal half of the first 3 ambulatory legs is present. The sternum and abdomen are visible, the latter being oblong-triangular and unusually wide for a male; the third, fourth, and fifth segments are fused; the sixth has rapidly converging sides; the seventh is wider than long.

Paratype.-Portion of a right cheliped, comprising the carpus, manus, and a small basal piece of each finger. Cat. No. 2258, Mus. Phila. Acad. Nat. Sci.

Measurements.-Length of manus above, excluding spine, $33 \mathrm{~mm}$., length at middle of outer surface $44 \mathrm{~mm}$., height of manus to base of superior spine $34 \mathrm{~mm}$.

The following is a description of the paratype:

This cheliped shows some features better than the holotype. The carpus has 4 nearly equal sides; the inner spine is visible, though broken off near its base; also a cross-section of a smaller spine at the distal outer angle which is broken off quite at the base; there is a longitudinal obtuse ridge on the proximal half of the segment terminating bluntly not far from the middle; if continued, it would cross the distal upper angle.

The manus is much flattened on the inside. At the distal end of the inner upper margin there is a spine pointing distad and a little upward and inward; its tip is broken off. Costæ of outer surface much lower and flatter than in the holotype; the upper costa fades out altogether proximally. The large lobe at the articulation with the dactylus is broken away, but the lobe below it is large and projects distally well over the dactylus. On the inner surface of the manus, half-way up and at one-fifth the distance behind the distal end, there is a slender spine (with tip broken off) pointing inward and slightly distad. A similar spine has been partially uncovered on the major chela of the holotype. The dactylus has one large, low, dark-colored molariform prehensile tooth at its base (which shows that the cheliped is the minor one of the pair), and on the inner side a small crescentic, blackish, articulating knob. The corresponding protuberance on the manus has been broken off. 
Relationships.-This species differs, it will be seen, from typical Scylla by having the hands costate. One sees in Scylla serrata ${ }^{1}$ the vestige of a costa in the same place where the middle costa ends distally in S. costata. In other respects this is a true Scylla, as shown by the smooth carapace with 9 lateral teeth, the posterior of which is not elongate, and by the massive chelipeds. The large distal protuberances on the outer and inner surfaces of the hand are similar to those of serrata.

\section{Genus PORTUNUS Weber, 1795.}

Portunus gabbi, new species.

(Plate 3, Figures 2 to 7; Plate 6, Figures 1 and 2.)

Type locality.- Lower half of the valley of the Yaqui del Norte River, in the northern part of Santo Domingo, Haiti; probably lower Miocene; W. M. Gabb, collector.

Holotype.-Female. Cat. No. 2256, Mus. Phila. Acad. Nat. Sci.

Measurements.-Length of carapace, median, $45 \mathrm{~mm}$., width of carapace in front of lateral spines $76 \mathrm{~mm}$., width between outer angles of orbits $43 \mathrm{~mm}$., length of manus above, $26.3 \mathrm{~mm}$., distal height of manus $22.2 \mathrm{~mm}$.

The following is a description of this species:

The carapace of the holotype is broken in the middle, whence a crack extends to the left margin between the fourth and fifth teeth; the large lateral spines are both broken off at their base. Carapace very convex; the two areoles at the inner angle of the branchial region are strongly marked. The granules, which are large and numerous on the more elevated portions, are scanty toward the second to fifth lateral teeth, inclusive, and along the postero-lateral margins, and are very small and flat behind the front and on the intestinal region. The anterior of the gastric ridges can be made out and is very irregular, the posterior ridge is obscured by the break. The four frontal teeth are subtriangular, blunt, those of the middle pair wider than those of the outer pair, and definitely more advanced; median sinus $\mathrm{V}$-shaped, lateral sinuses $\mathrm{U}$-shaped. The lateral teeth of the carapace (to be seen best on the left side) appear conical in dorsal view, their sides being straight; tips all broken off. Base of lateral spine granulate and lacking an axial line of granules.

The right chela is the only one remaining; its manus has the four customary longitudinal ridges on the outer surface, but these are so broken away that one can not tell if they are granulate; the distal extremity of the second ridge (counting from the top) is smooth and punctate. The development of the double lobe at the outer articulation with the dactylus indicates that this is the larger of the two chelipeds. The fingers are covered with such a fine granulation as to be smooth to the naked eye, and have a triangular gape between them; the molariform teeth are unequal and dark-colored; the end of the fixed finger has the same dark color; the terminal fourth of the dactylus is missing.

The female abdomen is very broad, as in adult Portunus; there is a blunt transverse ridge on the middle half of the fourth and fifth segments; outlines not well shown, but the sides of the sixth segment converge gradually. 
Paratypes.-(a) A male taken at the type locality, much larger than the holotype. It lacks chelipeds. The lateral teeth of the carapace are narrower than in the smaller specimen, their sides somewhat concave. A curved transverse line of granules is seen on the branchial regions leading toward the lateral spine. Enough of the abdomen is exposed to show the sex and generic relation. Cat. No. 2566, Mus. Phila. Acad. Nat. Sci.

(b) A right chela, also from the type locality; the fixed finger is broken off not far from the base, the dactylus near its middle. Resembles in shape the chela of the holotype, but is much larger, having a maximum height of $32 \mathrm{~mm}$. No other difference is apparent, excepting the slightly greater height of the middle intercostal space of the outer surface. The lobe at the distal end of this space is broken off. Cat. No. 2254, Mus. Phila. Acad. Nat. Sci.

Additional material.-A dactylus of left cheliped, from the Yaqui Valley at Cercado de Mao (Bluff 3), Santo Domingo; lower Miocene; C. J. Maury, collector; 1916. This finger is of much smaller size (about $16 \mathrm{~mm}$. long) than those of the holotype and paratype (b); its grooves are more strongly marked, the deepest grooves being one on the upper half of the outer surface and one on the lower half of the inner surface; a short, shallow groove is at the proximal end of the lower half of the outer surface. (See plate 3, figs. 6 and 7.)

Relationships.-Although the genus Portunus (=Neptunus of authors) is represented in the West Indian region by several Recent species of moderate size, our Tertiary species suggests none of them, but is allied to the large Indo-Pacific species. It resembles especially $P$. pelagicus $s^{1}$ in the configuration of the carapace and the shape of the female chela and abdomen; it differs from pelagicus in lacking the posterior of the transverse granulate gastric ridges, in the chela not being quite so deep at the base of the fixed finger, and in the sixth segment of the abdomen in both sexes having less rapidly convergent sides. The abdomen of the male in gabbi is nearest that of $P$. trituberculatus, ${ }^{2}$ the sides of the coalesced (third to fifth) segment being even less convergent than in that species.

While the fossil species, owing to its wide male abdomen and feeble dorsal ridges, is a true Portunus, it has some features which link it with the genus Callinectes; e. g., the four median frontal teeth are related to those of $C$. bocourti, ${ }^{3}$ in bocourti the outer frontal teeth are larger than the inner, and are about as advanced or even more so; while in gabbi the inner teeth are larger and more advanced. The lateral teeth also resemble those of bocourti much more than they do any of the Portunus species.

Portunus tenuis, new species.

(Plate 7, Figure 7.)

Type locality. - The Yaqui Valley at Cercado de Mao (Bluff 3), Santo Domingo; lower Miocene; C. J. Maury, collector; 1916.

1 Cancer pelagicus Linnæus, Syst. Nat., ed. 10, vol. 1, p. 626, 1758.

2 Neptunus trituberculatus Miers, Ann. Mag. Nat. Hist., ser. 4, vol. 17, p. 221, 1876.

A. Milne-Edwards, Crust. Rég. Mex., p. 226, 1879. 
Material.-Two immovable fingers, both of the right side. The larger is holotype. Cat. No. 324478 , U. S. N. M.

Description.-Finger slender, except at the base; grooves 5, 2 outside, 2 inside, 1 below; all are deep except the upper one on the outside; intervening ridges blunt, with a narrow longitudinal strip of squamiform granules along the middle. Prehensile teeth uneven, the large teeth as a rule alternating with 2 or 3 small ones.

Relationship.-This finger resembles that of $P$. spinicarpus, ${ }^{1}$ except in shape, as in the latter it widens regularly from the tip to the palmar end.

Portunus, indeterminable species.

Material.-Two fingers incomplete, one a right major dactylus, the other larger and probably also a dactylus; if so, from the left side. From the Yaqui Valley at Cercado die Mao (Bluff 3), Santo Domingo; lower Miocene; C. J. Maury, collector; 1916.

Description.-The right finger has 3 deep grooves, 2 outside, not far apart, and 1 inside; in addition there is a very shallow groove just above the teeth, both inside and out.

The left finger has the same number of grooves, the middle one of the outer surface fading out distally, and the grooves near the teeth almost imperceptible.

In both fingers there is a line of punctæ but no furrow on the upper margin.

Genus CALLINECTES Stimpson, 1860.

Callinectes declivis Rathbun.

(Plate 9, Figures 1 and 2.)

Callinectes declivis Rathbun, Bull. U. S. Nat. Mus. No. 103, p. 162, plate 66, figs. 1-3, 1918.

(Type locality, Miocene of Banana River, Costa Rica; type, Cat. No. 324262,

U. S. N. M.)

Material.-Seven fingers, mostly with the proximal end broken off, as follows: 2 right dactyls, 2 left dactyls, 2 right immovable fingers, 1 left immovable finger. From the Yaqui Valley at Cercado de Mao (Bluff 3), Santo Domingo; lower Miocene; C. J. Maury, collector; 1916.

The following is a description of these specimens:

The dactyli have a deep groove above the middle both outside and inside and a shallower groove on both sides a little way from the teeth; above there is an impressed line of numerous punctæ.

The holotype, which is the sole type, lacks a dactylus and its propodal finger is much larger than any of the Yaqui specimens, but allowing for size, the specimens from the two places agree.

\section{Callinectes, indeterminable species.}

Material.-A piece of a left dactylus or movable finger, with both ends. broken off. From the Yaqui Valley at Cercado de Mao (Bluff 3), Santo Domingo; lower Miocene; C. J. Maurv, collector; 1916. 
The following is a description of this species:

The dactylus has the characteristic grooving common to small specimens of most of the Recent species of Callinectes. Further than the genus it is impossible to identify the specimen. The grooves are as follows: 3 outside, about equally spaced, and the lowest very shallow; 1 above, fading out distally, but the punctæ are continued; 3 inside, the upper groove very short, proximal, the middle one deep.

\section{Genus PODOPHTHALMUS Lamarck, 180r.}

Podophthalmus domingensis, new species.

(Plate 2, Figures 7 and 8.)

Type locality.-Lower half of the valley of the Yaqui del Norte River, in the northern part of Santo Domingo, Haiti; probably lower Miocene; W. M. Gabb, collector.

Holotype.-Cat. No. 2265, Mus. Phila. Acad. Nat. Sci.

Measurements.-Length of carapace exclusive of rostrum $38.3 \mathrm{~mm}$.; length including rostrum $42.4 \mathrm{~mm}$; ; width between tips of outer spines of orbits $66 \mathrm{~mm}$.; width between tips of spines at middle of carapace $72.2 \mathrm{~mm}$.; approximate length of propodus of cheliped $62 \mathrm{~mm}$.; distal height of manus exclusive of spine $24 \mathrm{~mm}$.; length of dactylus measured from external articulation with manus $40.2 \mathrm{~mm}$.

The following is a description of this species:

Carapace transversely oblong, armed with a strong spine at the anterolateral angle or outer angle of the orbit and a shorter spine at the lateral angle of the carapace, from which a transverse ridge bearing a single line of granules extends inward across one-third of the carapace; a blunt transverse ridge across the gastric region, and a rounded elevation on the inner part of the branchial region; surface granulate except near the posterior and posterolateral margins and a narrow strip behind the anterior margin and occupying half the width of the carapace. The margins, so far as visible, have a single line of granules; the anterior margin, exclusive of the T-shaped front is straight and transverse for more than half the width of the carapace; it then curves rapidly backward, forming a deep sinus within the antero-lateral spine and is interrupted by a slight notch at the inner end of the sinus; the antero-lateral spine projects forward and very little outward and is less advanced than the anterior margin; the lateral spine projects obliquely outward and forward; the margin between the spines is embedded in the matrix. Frontal projection T-shaped, limits of the cross-piece ill-defined. The long eyes characteristic of the genus are not exposed in the unique specimen.

Chelipeds slightly unequal. Their brevity would seem to indicate that the specimen is a female. The distal half or more of the merus is lacking; there appear to be granules on the margins and also in longitudinal bands; on the anterior or inner margin there is an erect compressed spine which, when the merus is horizontally placed, is situated close to the end of the antero-lateral spine of the carapace. Of the carpus only the long inner spine shows on the left side (fig. 7); it is transversely placed when the cheliped is flexed and is convex above with the point turned downward. The chelæ are flattened externally and the outer shell, so far as preserved, is smooth, excepting on the obliquely longitudinal ridge, which leads from the distal articulating condyle, and on the upper margin of the dactylus and the lower part of the inner sur- 
face of the palm. There is the base only of a good-sized spine at terminal end of upper margin of manus. On the outer face of the dactylus at the articulation there is a small, black, horny, outstanding knob. Prehensile edges of fingers furnished with very unequal, stout, rounded teeth with dark brown, horny caps. Tips of fingers acute.

Relationships. - The carapace of this species is considerably like that of $P$. vigil (Fabricius), ${ }^{1}$ which to-day inhabits the East Indian region and is found also in the post-Tertiary of Celebes, but in the latter the anterior margin is arched, the antero-lateral spine projects strongly sideways, and the chelæ are not externally flattened. The smooth, flattened fingers of $P$. domingensis are suggestive of Euphylax dovii, ${ }^{2}$ the podophthalmid which inhabits the west coast of tropical America. I have placed the new species in Podophthalmus rather than in Euphylax, by reason of the shape and distinct areolation of the carapace and the strong lateral spines.

\section{Family XANTHUDE.}

Genus ZANTHOPSIS M'Coy, 1849.

Zanthopsis bartholomæensis, new species.

(Plate 8, Figure 3.)

Material.-Represented by a single carapace, the margin of which is largely incomplete.

Hololype.-Cat. No. 166945 , U. S. N. M.

Type locality.-St. Bartholomew: Orient Point; picked up at base, but probably from limestone at top, of the section; Eocene; T. W. Vaughan, collector; February 21, 1914; 6915; L. I. 72 (c) (1914).

The following is a description of this species:

Carapace approximately one-fifth wider than long, posterior half fairly level, anterior half curving strongly downward toward the front and anterolateral margins. Mesogastric, protogastric, and cardiac regions well delimited. The mesogastric region becomes suddenly wide behind the narrow anterior part; this broad posterior pentagonal portion is elevated and smoothly rounded; on each protogastric region there is a pair of tubercles forming a transverse line of 4 ; in front of the inner tubercle of each pair, but a little further from the median line, there is another tubercle; the cardiac region is covered by an elevation smaller than that on the mesogastric region but similar, that is, its anterior slope is shorter and steeper than its posterior. The most conspicuous elevation is that on the branchial region at the widest part of the carapace; it consists of two large transverse tubercles placed one directly behind the other, or rather resembles a single elevation deeply bisected transversely; there is a low swelling on the branchial region opposite the gastro-cardiac suture. So far as can be made out, the antero-lateral margin is unarmed. Postero-lateral margins strongly convergent. Along these margins just behind the lateral angle there is a curved row of 3 upstanding tubercles; further back there is a lower, smaller tubercle, and between it and the posterior of the large tubercles there is still another, but minute, tubercle.

1 Portunus vigil Fabricius, Entom. Syst., Suppl., p. 363, 1798. Podophthalmus vigil Leach, Zool. Misc., vol. 2, p. 149, plate $118,1815$.

${ }^{2}$ Stimpson, Ann. Lyc. Nat. Hist. N. Y., vol. 7, p. 226, plate 5, fig. 5, 1860. 
The width across front and orbits is about two-fifths of the entire width of the carapace. The orbit is narrow, about one-third as wide as the front and is probably subcircular. Only the upper margin of the left orbit remains and - its characters are obscured by cracks in the carapace. Edge of front lacking.

Of the various species of Zanthopsis described, this one most resembles Z. leachii (Desmarest), ${ }^{1}$ which also is very uneven. The nodules, however, are very differently disposed in the two forms. The marginal tubercles are antero-lateral in leachii and postero-lateral in bartolomoensis.

\section{Genus PILUMNUS Leach, 1815.}

Pilumnus subequus, new species.

(Plate 9, Figure 9.)

Type locality.-The Yaqui Valley at Cercado de Mao (Bluff 3), Santo Domingo; lower Miocene; C. J. Maury, collector; 1916.

Material.-Dactylus of right and major cheliped. Cat. No. 324484, U. S. N. M.

The following is a description of this species:

A dactylus of small size, dark-colored, stout, strongly curved, with about 5 lines of punctæ, and above at the proximal end 4 granules. Prehensile teeth few (4 large and 1 small), shallow, subtriangular. A common type of dactylus among the numerous recent species of Pilumnus; the basal granules or spinules are, however, usually more numerous.

\section{ARCHAEOPILUMNUS, new genus.}

The following is a description of this genus:

Near Pilumnus. ${ }^{2}$ Carapace subquadrilateral, the penultimate tooth of the side margins most prominent; surface rough and deeply sculptured, posteriorly as well as anteriorly. Front bilobed, lobes concave, their outer angle produced but not dentiform. Orbit and basal antennal segment as in Pilumnus. Chelipeds stout, rough, unequal; fingers elongate, deflexed.

This genus is distinguished from Pilumnus chiefly by the fingers, which are long instead of short and stout; by the posterior part of the carapace being deeply sculptured, which is usually not the case in Pilumnus; and by the outer angle of the front not being separated from the remainder of the front.

\section{Archæopilumnus cælatus, new species.}

(Plate 6, Figures 6 and 7; Plate 7, Figures 10 to 13; Plate 8, Figures 4 to 7.)

Type locality.-Lower half of the valley of the Yaqui del Norte River, in the northern part of Santo Domingo, Haiti; probably lower Miocene; W. M. Gabb, collector.

Holotype.-Male. Cat. No. 2261, Mus. Phila. Acad. Nat. Sci.

'Compare fig. 1, plate 1, of Bell's Monograph of the Fossil Malacostracous Crustacea of Great Britain, part 1, 1857.

${ }^{2}$ Leach, Trans. Linn. Soc. London, vol. 11, pp. 309 and 321, 1815. Type, P. hirtellus (Linnæus, 1761). 
Paratypes.-The paratypes are from the same locality as the holotype: $a$, male, Cat. No. 2260; $b$, female, Cat. No. 2262; $c$, male, and $d$, female, Cat. No. 2263; all in Mus. Phila. Acad. Nat. Sci.

Measurements. - Length of carapace of holotype on median line 34.3 mm., width of carapace $45.2 \mathrm{~mm}$., width of front $13.2 \mathrm{~mm}$., width between outer angles of orbits $25.3 \mathrm{~mm}$.

The following is a description of this species:

The regions are surrounded by deep furrows and are more or less subdivided. The epigastric lobes are separated from the protogastric, and the crescentic urogastric lobe from the mesogastric; the hepatic lobe is separated from the dentate lateral border, while the branchial region is divided into an epibranchial lobe, which incloses the penultimate lateral spine, a mesobranchial lobe, which is divided in three, and a metabranchial lobe which is separated partly from the cardiac region by a sharp, thumb-nail impression, while it is anteriorly confluent with that region by a narrow connecting elevation; cardiac region truncate behind and longitudinally grooved in its anterior two-thirds; the elevation occupying the intestinal region is continued laterally across the branchial region; the frontal region is separated from the edge of the front by a shallow depression. The surface of the carapace is rough, except in the furrows and on the epigastric lobes, the roughness consisting of (1) subacute, somewhat imbricating, white-tipped tubercles, most evident on the sides and posterior half, and (2) a mixture of blunter tubercles and erosions on the middle of the anterior half. Antero-lateral teeth 5, thick, subconical; the first one, at the outer angle of the orbit, is small, little advanced; first interspace the greatest of all; fourth tooth largest, third tooth next in size, fourth and fifth curved. Above the posterior margin a row of fine bead granules. The marginal lobes of the front are bordered by 12 or 13 granules, the lobes are more advanced at the inner angles, the outer angles are slightly advanced, but not isolated, intermediate space concave, median sinus V-shaped. Margin of orbit granulate, upper margin raised, edge biemarginate, the notches continued backward in a furrow; a larger notch below the outer angle; lower margin more advanced than upper, furnished with 2 stout, granulated teeth, one of which is within the outer angle and the other at the inner angle, next to the antennal segment. This segment touches with its outer angle the bent-down edge of the front; it has a longitudinal granulated ridge. A piece of the eyestalk shows a few small granules above at the base.

The chelipeds are unequal, the smaller palm about four-fifths as high as the larger. Merus very broadly triangulate, not much longer than the distal width, outer surface sparsely covered with sharp granules and tubercles; upper margin with 3 spines, the distal one much the largest. Carpus rough with short spines; the spine at the inner angle is large and bears a spinule on its posterior margin. Manus armed with spines on the outer surface except near the fingers, the spines arranged mostly in 6 or 7 irregular rows. The lower edge of the propodus is sinuous, the distal half of the finger being strongly deflexed; the dactylus is longer than the upper margin of the palm; fingers with a few irregular teeth, a large tooth at the base of the dactyl in the larger chela; fingers not gaping; dactylus spinulous on the basal third of its upper margin; the dark color extends the full length of the prehensile edges, but elsewhere in the larger chela it spreads over all but the very base of the dactylus, in the smaller chela not so far; on the fixed finger the color extends about three-fifths the length on the lower edge. The anterior surface of the merus of the ambulatory legs and the posterior surface of the last leg are granulate, the upper margin spinous; remaining joints of legs not visible. 
Abdomen (male) subtriangular, 7 segments separate, diminishing successively in width from the third to the seventh; fifth segment longest, seventh triangular.

Females: In the female the cheliped (only one is present) is smaller, the propodus and dactylus more spinous, the fixed finger more horizontal. In the male, the spines and tubercles of the manus disappear toward the lower margin, in the female they become more numerous but smaller. In the female there is not only a row of spines on the upper margin of the dactylus, but a row of tubercles or granules on the outer surface.

Abdomen of female oblong-oval, second segment narrower than first and third, sixth segment longer than fifth, seventh longer than sixth.

Variations.-In comparing the 5 specimens at hand the areoles of the carapace appear more sharply cut in the small specimens than in the large ones.

\section{Genus PANOPEUS Milne-Edwards, 1834 .}

\section{Panopeus, indeterminable species.}

Material.-Distal end of the right immovable finger. From the Yaqui Valley at Cercado de Mao (Bluff 3), Santo Domingo; lower Miocene; C. J. Maury, collector; 1916.

The following is a description of this specimen:

This fragment might belong to any one of 3 common Recent species, viz, $P$. americanus, ${ }^{1}$ occidentalis, ${ }^{2}$ or herbstii. ${ }^{3}$ There is a deep groove on either side not far above the lower margin, the grooves ending at the sinus above the terminal tooth; below there are 2 shallow grooves; not far from the prehensile teeth there is on either side a row of deep punctæ. Teeth unequal, only 10 preserved, and in general alternating large and small.

Genus and species indeterminable.

Material.-Distal end of a dactylus or movable finger. From the Yaqui Valley at Cercado de Mao (Bluff 3), Santo Domingo; lower Miocene; C. J. Maury, collector; 1916.

The following is a description of this specimen:

The fragment is not bent sideways, so that it is not clear whether it is a right or left finger; it is bent strongly downward toward the blunt, distal end, has no grooves, but a few punctr arranged in lines; occupying less than half of the prehensile edge, at its proximal end are 4 tuberculiform teeth (2 large, 2 small, alternating) which are situated one side of the middle.

\section{Family OCYPODIDE.}

\section{SANDOMINGIA, new genus.}

The following is a description of this genus:

Carapace wide, wider at the antero-lateral than at the postero-lateral angles; anterior margin moderately arcuate, emarginate at the outer fourth. Front a narrow lobe, less than one-twelfth as wide as carapace. A lateral tooth behind the orbital tooth.

\footnotetext{
${ }^{1}$ Saussure, Rev. Mag. Zool., ser. 2, vol. 9, p. 502, 1857.

2 Saussure, loc. cit.

${ }^{3}$ Milne-Edwards, Hist. Nat. Crust., vol. 1, p. 403, 1834.
} 
Orbits long, shallow trenches, extending the whole width of the carapace except for the front, and bordered above except for the outer third by a narrow surface of varying depth, similar to that in Uca (=Gelasimus).

Sandomingia seems to be nearest Uca Leach, ${ }^{1}$ the genus of fiddler crabs. Uca has the same shape of carapace, with similar depressions, orbits occupying nearly the whole width of carapace, with a thickened, bimarginate upper edge. On the other hand, in Sandomingia the antero-lateral angle is bidentate, there is a definite notch in the upper margin of the orbit, the orbit is very shallow, and the chelipeds are large and equal.

The equality in the chelipeds suggests the possibility of this crab being a portunid allied to the long-eyed forms, Podophthalmus and Euphylax, but the latter have the orbits deeply hollowed at the outer ends to hold the corneæ and lack the facet-like upper margin of the orbit.

\section{Sandomingia yaquiensis, new species.}

(Plate 8, Figures 1 and 2.)

Type locality.-Lower half of the valley of the Yaqui del Norte River, in the northern part of Santo Domingo, Haiti; probably lower Miocene; W. M. Gabb, collector; 1 specimen.

Holotype.-Cat. No. 2257, Mus. Phila. Acad. Nat. Sci.

Measurements.-Length of carapace, exclusive of rostral lobe, 23 $\mathrm{mm}$., width of carapace at antero-lateral angles (approximate, because tips of teeth are broken off) $42 \mathrm{~mm}$., width of frontal lobe at base $3 \mathrm{~mm}$.

The following is a description of this species:

Carapace flat in the middle, sloping rapidly down to the anterior and lateral margins; surface smooth and a little uneven; a shallow furrow defines the gastric region. Anterior margin finely granulate, granules not in a single row; lower edge of flat supraorbital space or "eyebrow" having a single row of granules; "eyebrow" very narrow, height about one-fifteenth of its length in a transverse direction, inner end at base of frontal lobe. Surface of orbit smooth and shallow. Antero-lateral tooth an equilateral triangle; it and the tooth behind it are separated by a U-shaped interspace and project about equally sideways; the tips are broken off, so that it is impossible to tell exactly about this.

Chelipeds equal; only a portion of the merus or arm-joint of each is visible; it is stout, triangular in cross-section, upper surface concave and smooth, posterior and inferior margins blunt and granulate, anterior margin subacute and furnished with tubercles of varying size arranged in two irregular rows.

\section{Superfamily OXYRHYNCHA.}

Family PARTHENOPIDE.

Genus PARTHENOPE Weber, 1795 .

Parthenope (Platylambrus) obscura, new species.

(Plate 7, Figures 5 and 6.)

Type locality. - The Yaqui Valley at Cercado de Mao (Bluff 3); Santo Domingo; lower Miocene; C. J. Maury, collector; 1916. 
Material.-Dactylus of right cheliped, holotype. Cat. No. 324487 , U. S. N. M.

The following is a description of this species:

The distal portion of the dactylus is lacking. The proximal end of the upper surface is broad and flat and inclosed by 5 irregular granulated knobs; sides compressed, in the middle slightly concave, and unevenly granulate, granules most numerous on the inner surface. Prehensile teeth very low and flat, the proximal tooth more than twice as large as the next one.

Relationships. - In its general characters resembles the dactylus of the recent $P$. (Platylambrus) serrata (Milne-Edwards), ${ }^{1}$ which has a shorter finger, prominences at proximal end above more spiniform, sides not concave.

\section{Parthenope, indeterminable species.}

(Plate 7, Figures 8 and 9.)

Material.-Dactylus of right cheliped, from the Yaqui Valley at Cercado de Mao (Bluff 3), Santo Domingo; lower Miocene; C. J. Maury, collector; 1916.

The following is a description of this species:

Resembles the preceding, but less curved and more slender, sides flat but not concave, outer side more granulate than inner, and having an uneven, longitudinal line of coarse granules not far above the fingers on the proximal half; upper surface flattened along the proximal half, and bordered by stout spines and spinules; one of these spines projects outward above the condyle articulating with the palm on the outer side, and is seen at the top of figure 8 at the left-hand end; the condyle is broken off and shows in cross-section; prehensile tubercles 10, the proximal pair confluent; tuberc'es low but better developed than in the preceding species. Upper part of distal end of finger missing.

\section{Genus MESORHCEA Stimpson, 1871 .}

\section{Mesorhœa mauryæ, new species.}

(Plate 7, Figures 1 to 4.)

Type locality.-The Yaqui Valley at Cercado de Mao (Bluff 3), Santo Domingo; lower Miocene; C. J. Maury, collector; 1916.

Material.-Two specimens, a right manus with propodal finger attached (holotype) and a right manus of smaller size, without fingers but with carpus attached (paratype). Cat. No. 324489 , U. S. N. M.

Measurements. - Length of holotype on outer margin, this being the most complete, $8 \mathrm{~mm}$.; greatest height, measured on inner surface, $4 \mathrm{~mm}$.

The following is a description of this species:

The holotype has 8 teeth on the upper margin, 13 on the outer and 10 on the inner margin; teeth of outer and inner margins short, those of the outer margin the smallest, those of the inner margin intermediate in size. The inner surface widens greatly from the proximal to the distal end, lower surface

${ }^{1}$ Lambrus serratus Milne-Edwards, Hist. Nat. Crust., vol. 1, p. 357, 1834. 
of equal width throughout, outer surface a little wider in middle third than toward ends.

Propodal finger short, slender, directed strongly inward and distad but scarcely downward. It does not, however, reach distad beyond the line of the upper margin of the palm.

The carpus has 5 low ridges which are finely tuberculate or granulate.

Relationship.-These short hands - short for the family Parthenopidæ - belong without doubt to the genus Mesorhoea, having considerable resemblance to the Recent species, $M$. sexspinosa Stimpson, ${ }^{1}$ of the Florida Keys and West Indies. In the latter the palms are a little longer and slenderer and the inner and outer surfaces are concave.

\section{BIBLIOGRAPHY OF WEST INDIAN TERTIARY DECAPODA.}

1866. GuPPY, R. J. Lechmere. On the relations of the Tertiary formations of the West Indies; with a note on a new species of Ranina, by Henry Woodward, Esq., F. G. S.; and on the Orbitoides and Nummulinæ, by Prof. T. Rupert Jones, F. G. S. Quart. Jour. Geol. Soc. London, vol. 22, pp. 570-592, plate 26, 3 text-figures.

Name only, Ranina porifera, listed by Guppy on p. 572 ; locality indicated (p. 571) as San Fernando beds, "lower Miocene," Trinidad, in "irregular dark-blue limestone, containing numerous fossils generally converted into calcspar, or replaced by semiliquid asphalt."

1866. WOODWARd, Henry. (See above under Guppy.) Note on a new species of Ranina ( $R$. porifera) from the Tertiary strata of Trinidad. Quart. Jour. Geol. Soc. London, vol. 22 , pp. 591-592, plate 26 , fig. 18 .

List of the known species of Ranina (p. 591). Description of R. porifera (p. 592) and figure on plate 26 , fig. 18.

1909. Guppy, R. J. Lechmere. Preliminary notice of a discovery of fossils in the Tamana District, Trinidad. Bull. Agric. Dept. Trinidad, pp. 5-6, 1 plate.

Describes the new species, Ranina cuspidata, and gives one figure (fig. 1) on the plate. From Tamana beds, "lower Miocene," Trinidad.

1911. Guppy, R. J. Lechmere. On a collection of fossils from Springvale, near Couva, Trinidad. Papers Agric. Soc. Trinidad and Tobago, No. 440, laid before the Society Dec. 20, 1910, pp. 1-15.

Ranina cuspidata listed (p. 14), with a reference to its original description.

${ }^{1}$ Bull. Mus. Comp. Zoöl., vol. 2, 136, 1871. 


\section{DESCRIPTION OF PLATES.}

\section{Plate 1.}

Figs. 1 to 7. Callianassa anguillensis, n. sp.

1. Holotype, outer side of right manus $\times 1.4$.

2. Paratype (a), inner side of right manus, $\times 1.4$.

3. Paratype (a), outer side of right manus, $\times 1.4$.

4. Holotype, upper edge of right manus, $\times 1.4$.

5. Paratype $(d)$, outer side of left manus, $\times 1.4$.

6. Paratype $(b)$, finger, $\times 1.4$.

7. Paratype (a), lower edge of right manus, $\times 1.4$.
Frgs. 8 to 13. Callianassa pellucida, n. sp.

8. Paratype (b), outer side of right manus, $\times 2.8$.

9. Paratype (a), outer side of right manus, $\times 2.8$.

10. Paratype $(a)$, distal view of right manus, $\times 5$.

11. Paratype $(a)$, lower edge of right manus, $\times 2.8$.

12. Holotype, upper view of left movable finger (tip broken off), $\times 2.8$.

13. Holotype, outer and slightly ventral view of left movable finger, $X$ 2.5 .

\section{Plate 2.}

Figs. 1 to 6. Callianassa miocenica, n. sp.

1. Holotype, outer side of left manus, $\times 1.9$.

2. Holotype, proximal end of left manus, $\times 1.9$.

3. Holotype, inner side of left manus, $\times 1.9$.

4. Holotype, lower edge of left manus, $\times 1.9$.
Fra. 5. Holotype, distal end of left manus, $\times 1.8$.

6. Holotype, upper edge of left manus, $\times 1.9$.

7, 8. Podophthalmus domingensis, n. sp.

7. Holotype, dorsal view, nat. size.

8. Holotype, anterior view, nat. size.

\section{Plate 3.}

FIG. 1. Lyreidus fastigatus, n. sp. Holotype, dorsal view of carpus of left cheliped, $\times 3$.

2 to 7. Portunus gabbi, n. sp.

2. Holotype, + , ventral view, slightly reduced.

3. Holotype, ㅇ, dorsal view, slightly reduced.
Frg. 4. Paratype (a), $\sigma^{7}$, dorsal view, slightly reduced.

5. Paratype (b), outer view, slightly reduced.

6. Dactylus of left chela, inner view, $\times 2$.

7. Same, outer view, $\times 2$.

\section{Plate 4.}

Scylla costata, n. sp.

Fig. 1. Holotype, $\sigma^{7}$, dorsal view, $\times 0.85$. FIG. 2. Holotype, $\sigma^{7}$, anterior view, $\times 0.85$.

\section{Plate 5.}

Scylla costata, n. sp.

FIG. 1. Holotype, $\sigma^{7}$, ventral view, $\times 0.87$. Fig. 2. Holotype, $\sigma^{7}$, posterior view, $\times 0.87$.

\section{Plate 6.}

Figs. 1, 2. Portunus gabbi, n. sp.

1. Paratype $(a), \sigma^{\top}$, part of ventral view, nat. size.

2. Holotype, $\%$, anterior view, slightly reduced.

3 to 5. Scylla costata, n. sp.

3. Paratype, dorsal view of cheliped, nat. size.
Frg. 4. Paratype, inner view of cheliped, nat. size.

5. Paratype, outer view of cheliped, nat. size.

6, 7. Archoeopilumnus coelatus, n. sp.

6. Paratype $(b)$, ㅇ, ventral view, $\times 1.33$.

7. Paratype $(b), \%$, dorsal view, $\times 1.33$. 


\section{Plate 7.}

Figs. 1 to 4. Mesorhøa mauryø, n. sp.

1. Holotype, propodus of right chela, outer view, $\times 3.75$.

2. Same, inner view, $\times 3.5$.

3. Paratype, carpus and propodus of right cheliped, outer view, $\times 3.75$.

4. Same, upper view. $\times 3.75$.

5, 6. Parthenope (Platylambrus) obscura, n. sp.

5. Holotype, dactylus of right chela, inner view, $\times 3$.

6. Same, outer view, $\times 3$.
FIg. 7. Portunus tenuis, n. sp., holotype, immovable finger of right chela, outer view, $\times 3$.

8, 9. Parthenope, sp. indet.

8. Dactylus of right chela, outer view, $\times 3.5$.

9. Same, inner view, $\times 3.5$.

10 to 13. Archœopilumnus cœlatus, n. sp.

10. Paratype (b), \&, anterior view, $\times 1.4$.

11. Holotype, $\sigma^{7}$, ventral view, $\times 1.33$.

12. Holotype, $\sigma^{\top}$, dorsal view, $\times 1.33$.

13. Holotype, $\sigma^{7}$, anterior view, $\times 1.33$.

\section{Plate 8.}

Fıas. 1, 2. Sandomingia yaquiensis, n. sp., holotype.

1. Dorsal view, slightly enlarged.

2. Anterior view, nat. size.

3. Zanthopsis bartolomaensis, n. sp., holotype, dorsal view, $\times 1.4$.
Figs. 4 to 7. Archoeopilumnus calatus, n. sp.

4. Paratype $(c), \sigma^{7}$, dorsal view, $\times 1.33$.

5. Paratype $(c), \sigma^{7}$, ventral view, $\times 1.4$.

6. Paratype $(a), \sigma^{7}$, dorsal view, $\times 1.37$.

7. Paratype $(d)$, , , ventral view, $\times 1.4$.

\section{Plate 9.}

Fras. 1, 2. Callinectes declivis Rathbun.

1. Dactylus of right chela, inner view, $\times 2$.

2. Same, outer view, $\times 2$.

3. Cragonidæ, gen. and sp. indet., telson, dorsal view, $\times 3.1$.

4. Eryonidæ, gen. and sp. indet., ischium of first right cheliped, upper view, $\times 3$.

5. Persephona prepunctata, n. sp., holotype, merus of right cheliped, upper view, $\times 3$

6, 7. Paguridæ, gen. and sp. indet.

6. Dactylus of left chela, upper side, $\times 3$.

7. Same, lower side, $\times 3$.

8. Cycloes bairdii Stimpson, piece of left manus with propodal finger, outer view, $\times 4$.
Fig. 9. Pilumnus subequus, n. sp., holotype, dactylus of right chela, outer view, $\times 5$.

10, 11. Callianassa latidigita, n. sp.

10. Paratype, dactylus of left chela, upper side, $\times 4$.

11. Same, holotype, propodal finger of left chela, upper side, $\times 4$.

12. Calappella (?), sp., piece of right manus, outer side, $\times 3$.

13 to 15. Petrochirus inequalis, n. sp.

13. Holotype, right chela, outer view, $\times 1.5$.

14. Same, showing dorsal view of both chelæ, $\times 1.5$.

15. Same, ventral view (fingers pointing to bottom of plate), $\times 1.5$. 


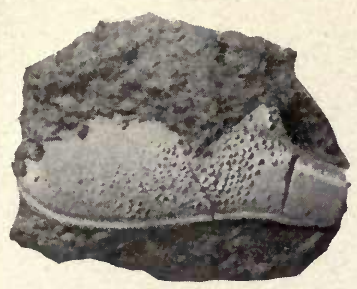

1

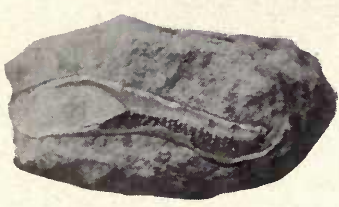

4

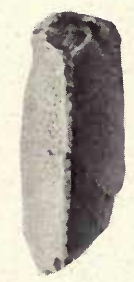

7

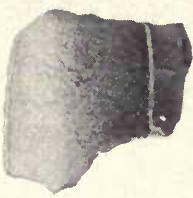

8

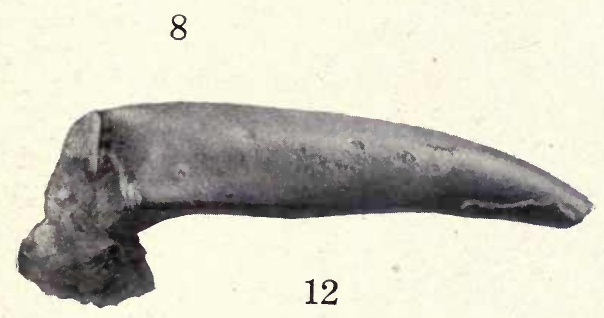

9

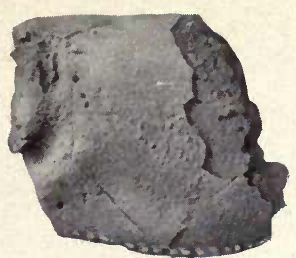

2

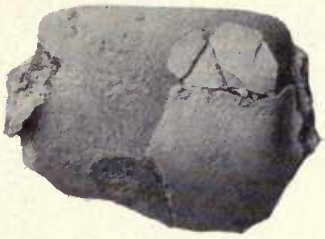

5
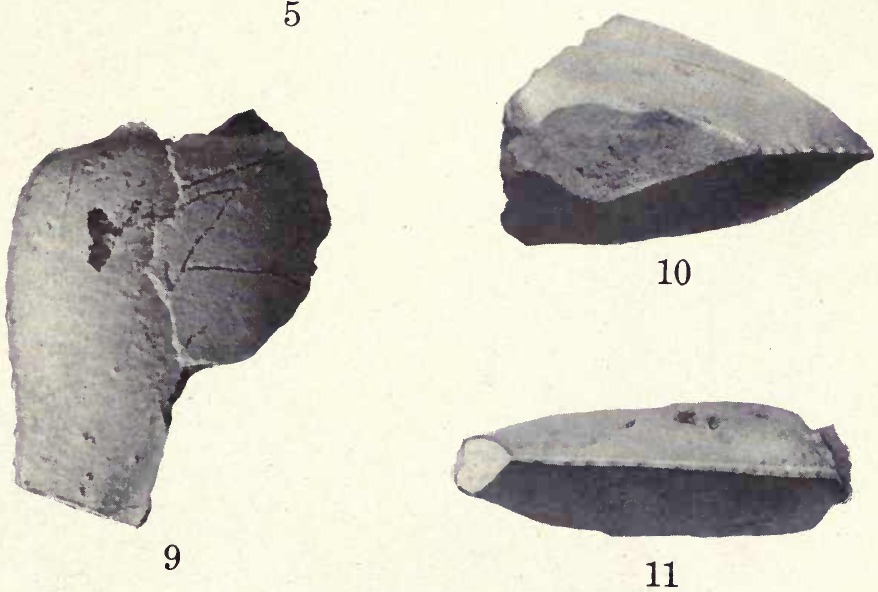

10

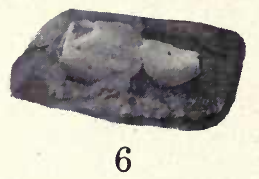

11

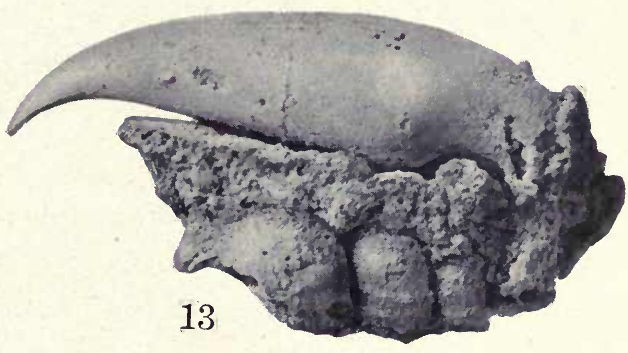



RATHBUN
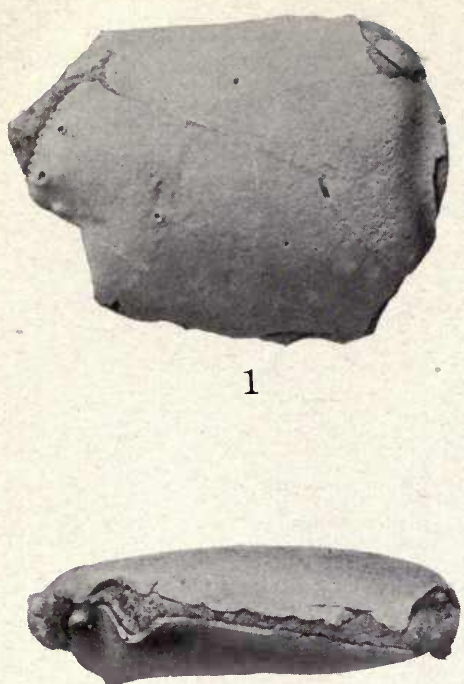

4

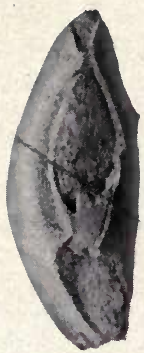

2

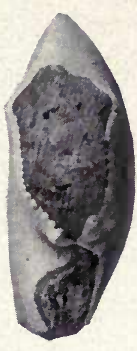

5
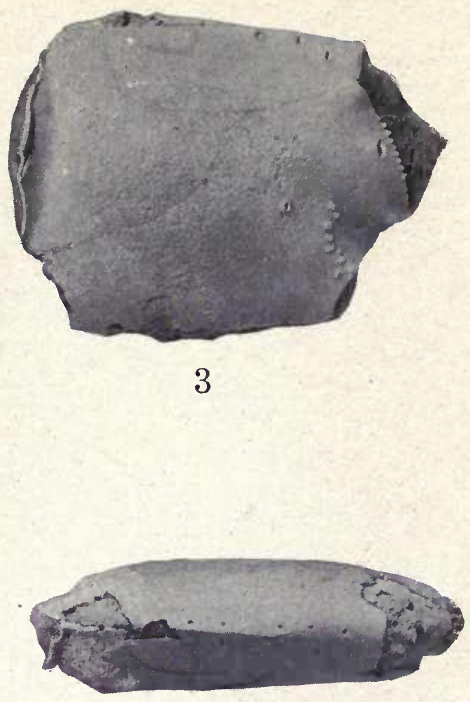

6

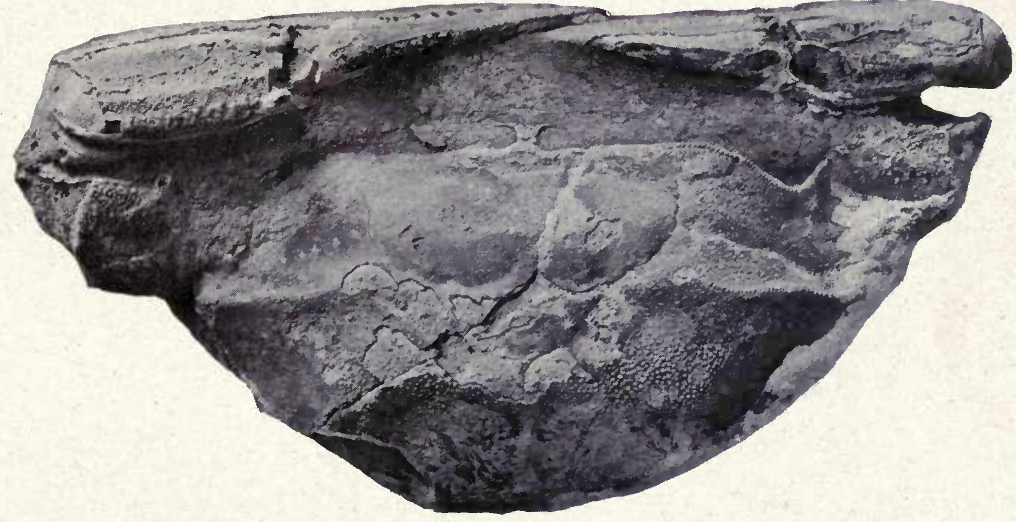

7

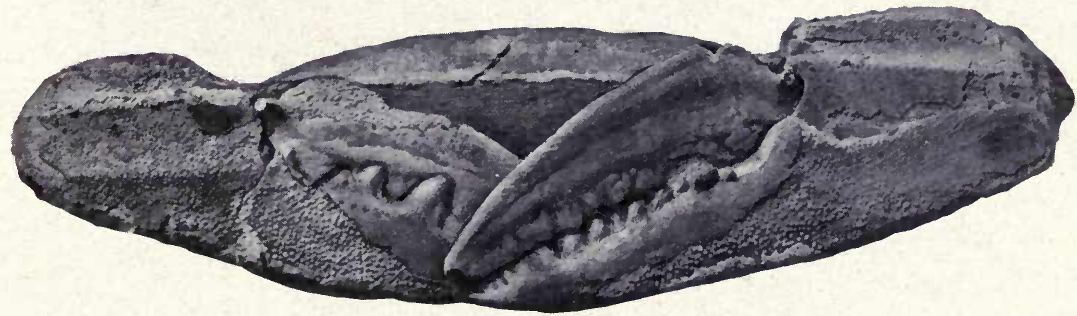





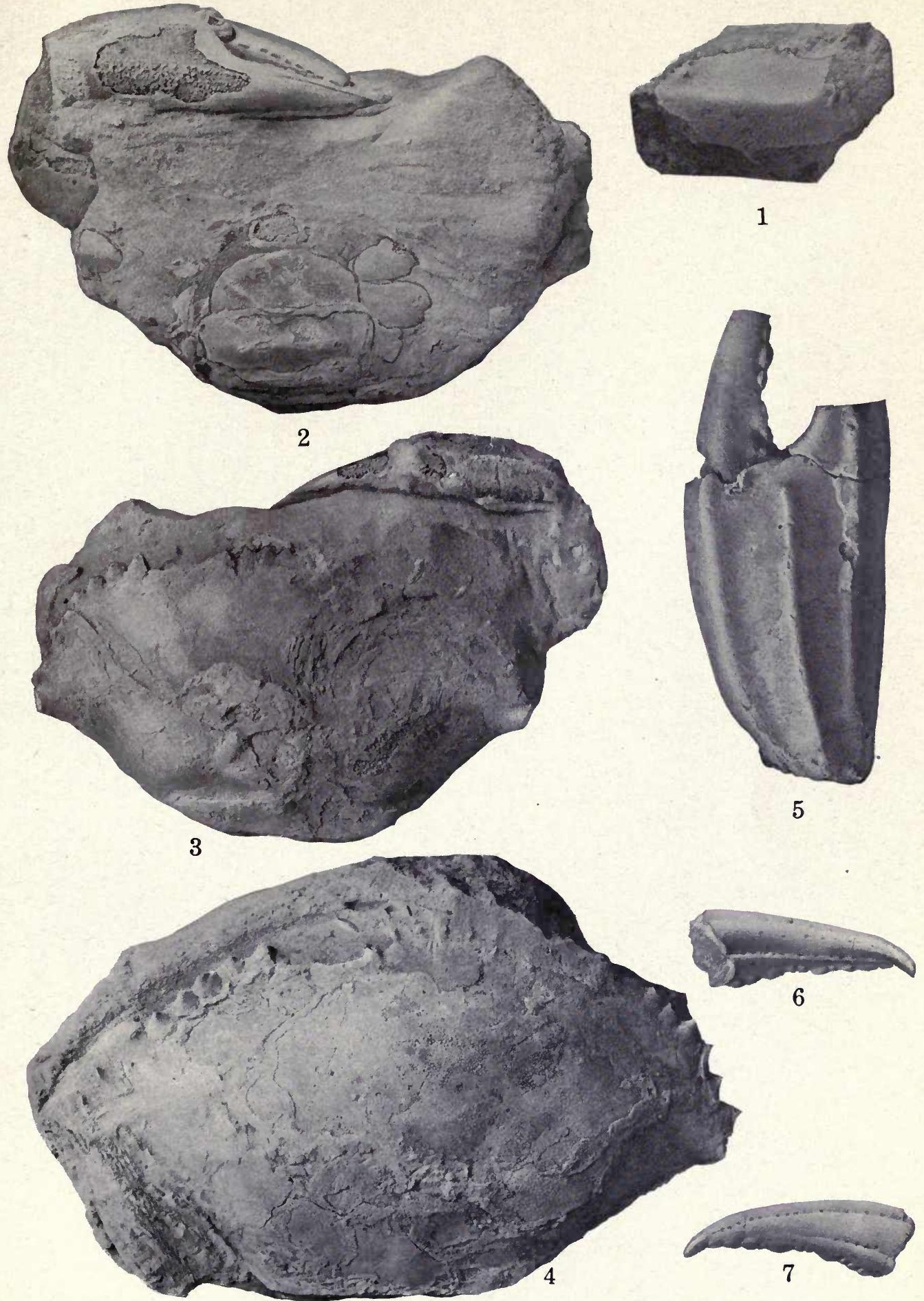




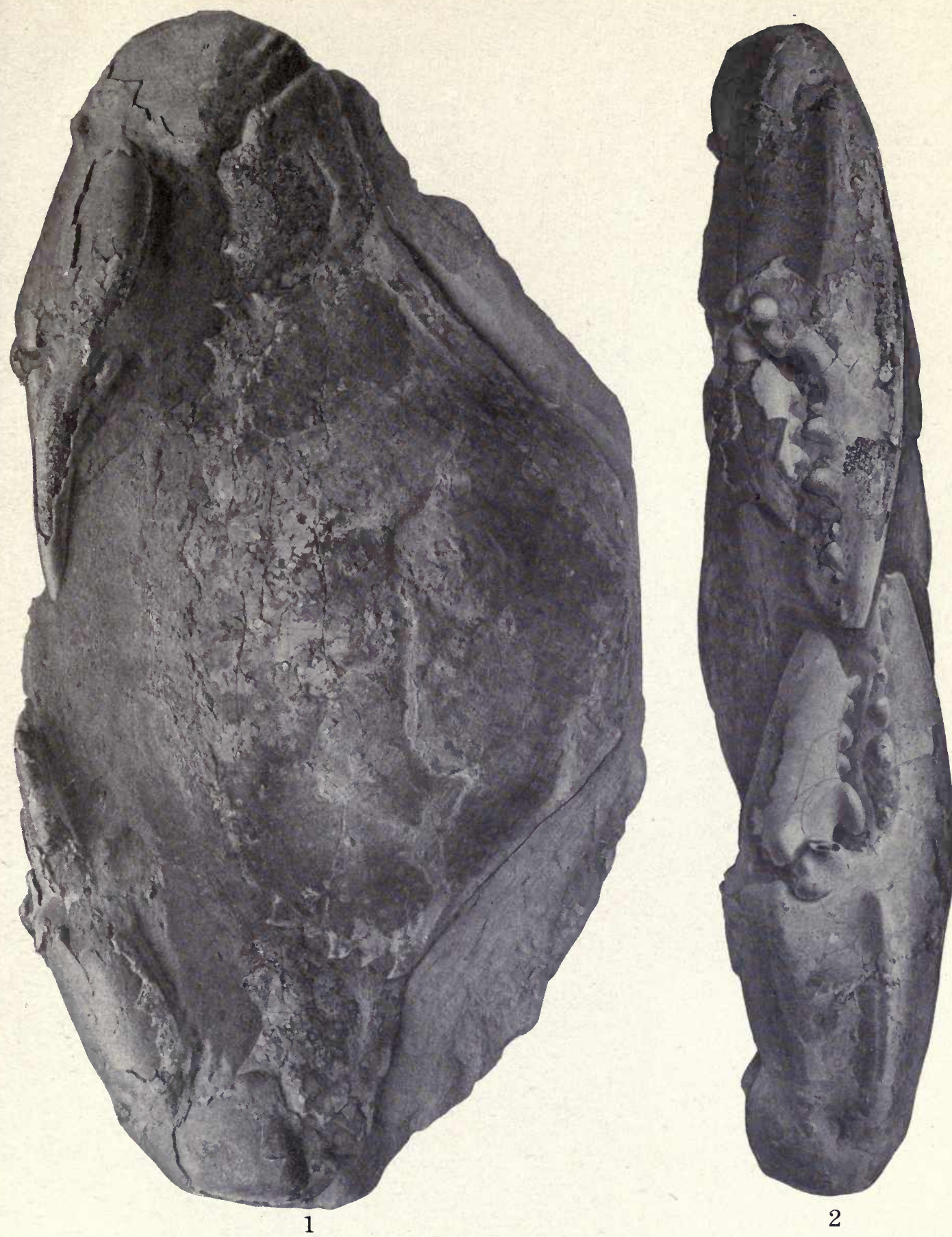



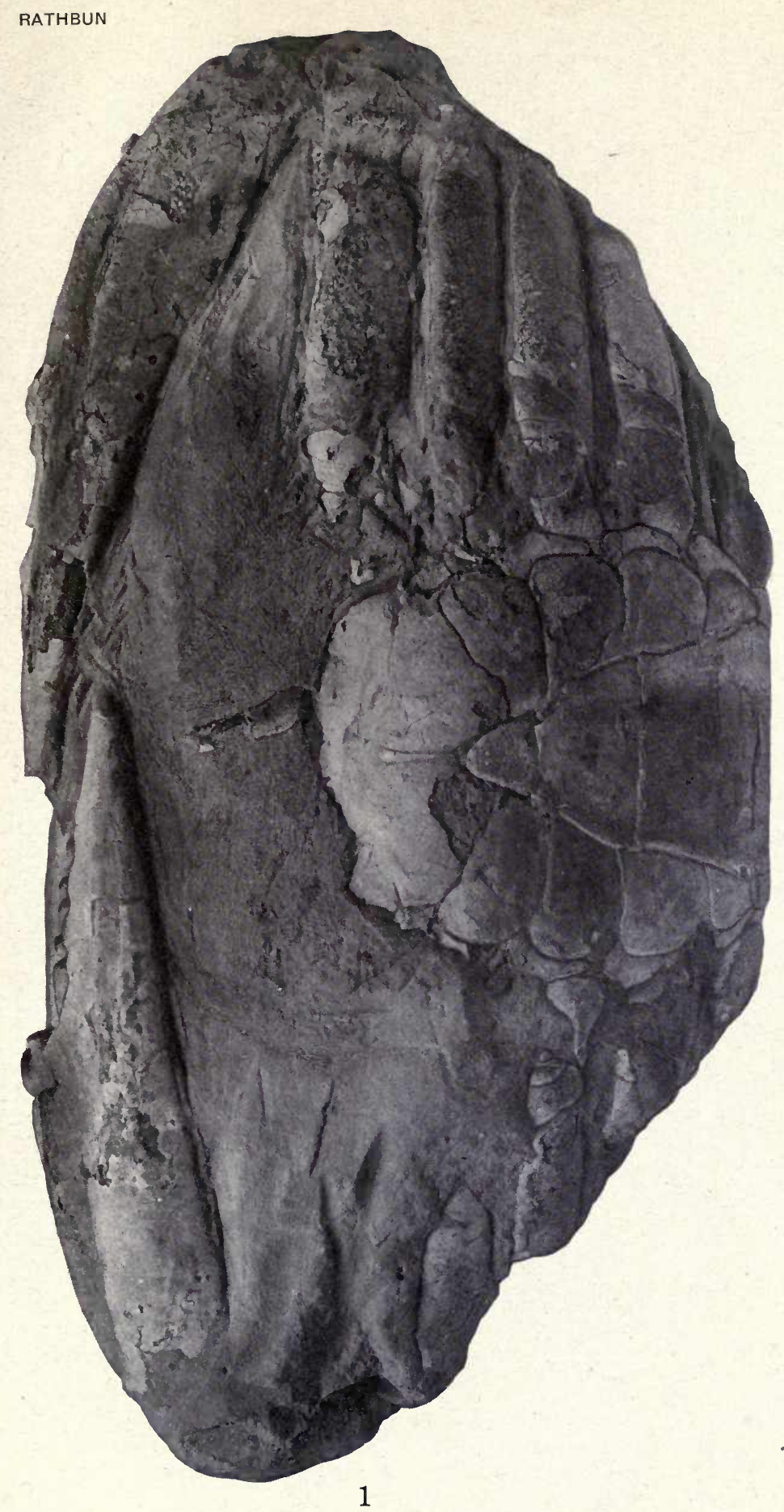

PLATE 5

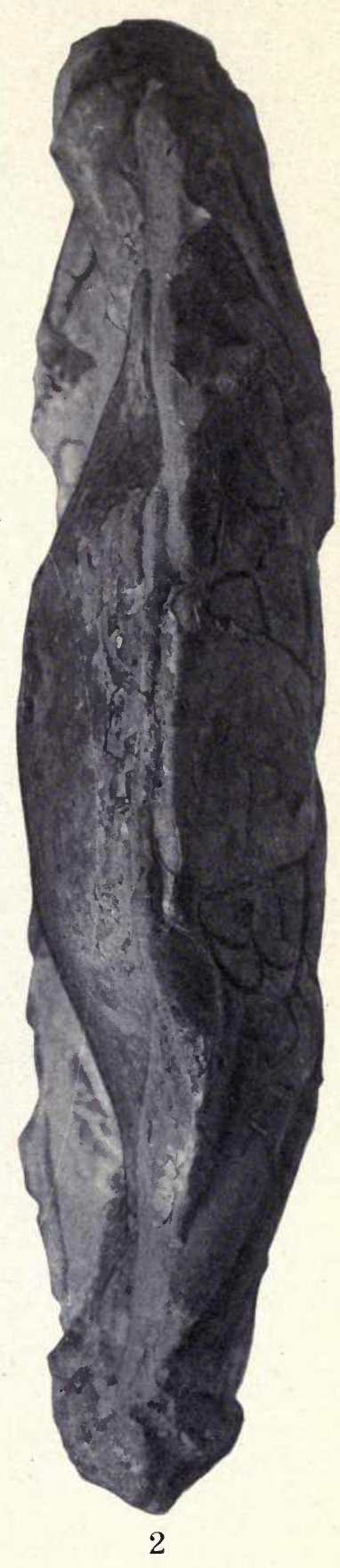




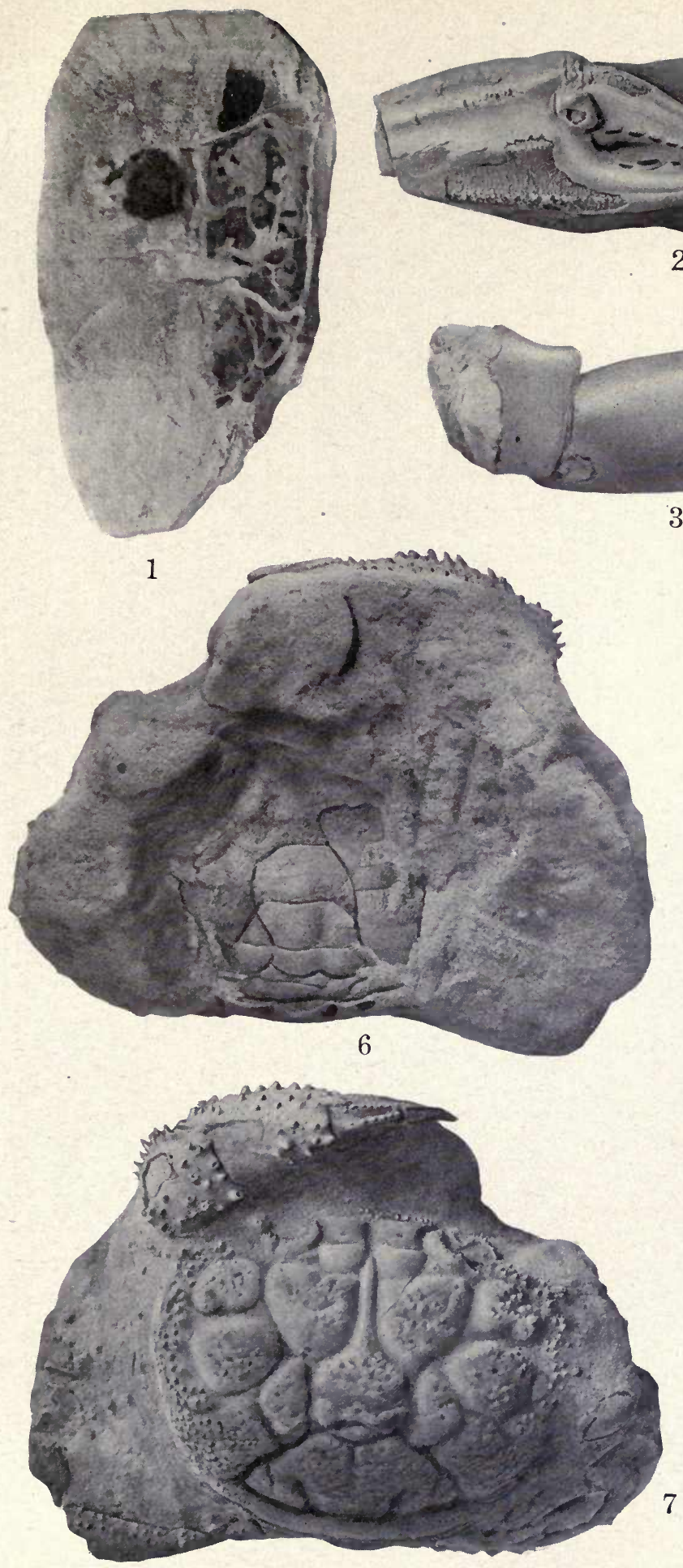
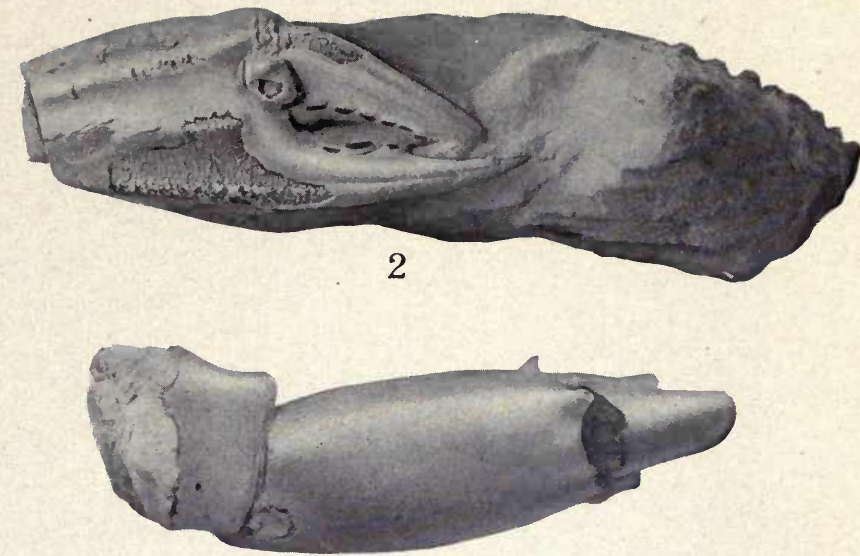

3
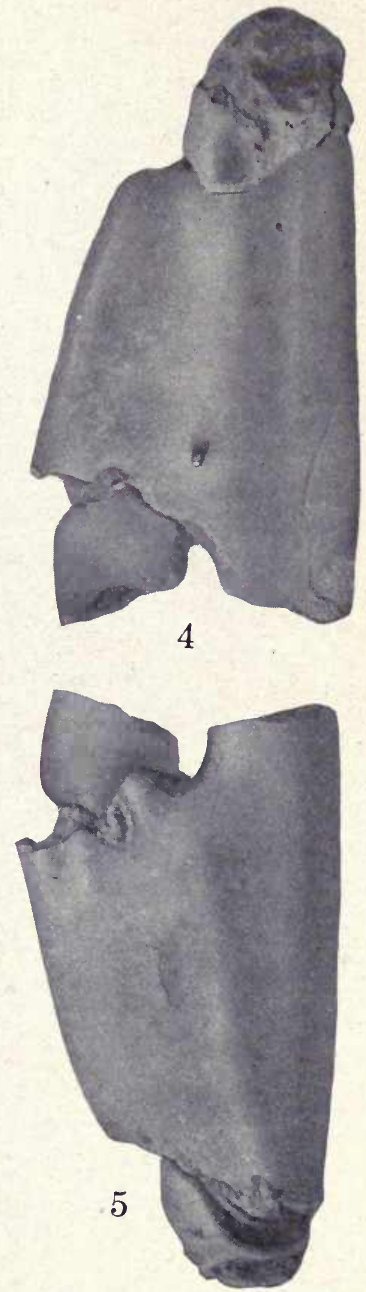



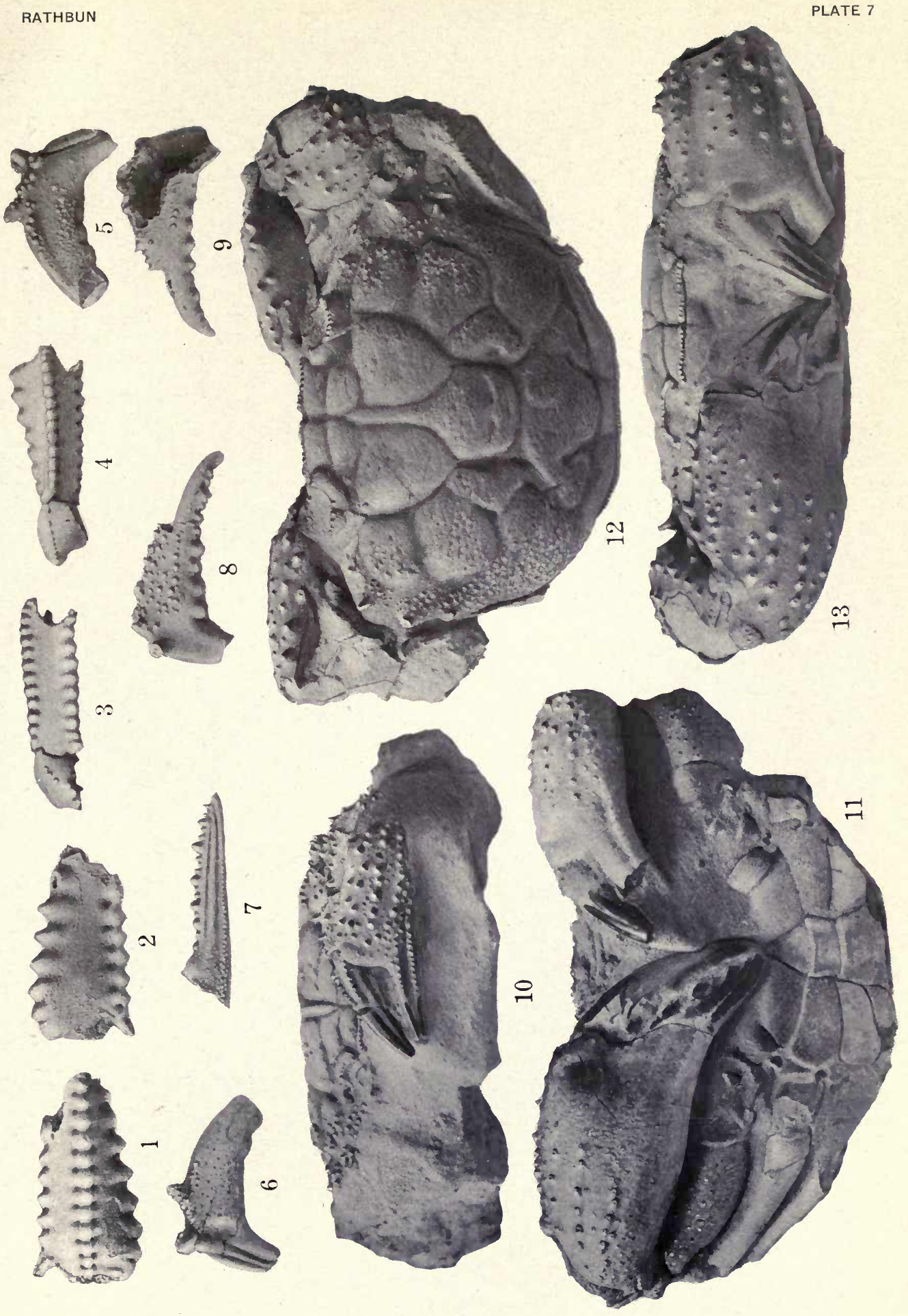




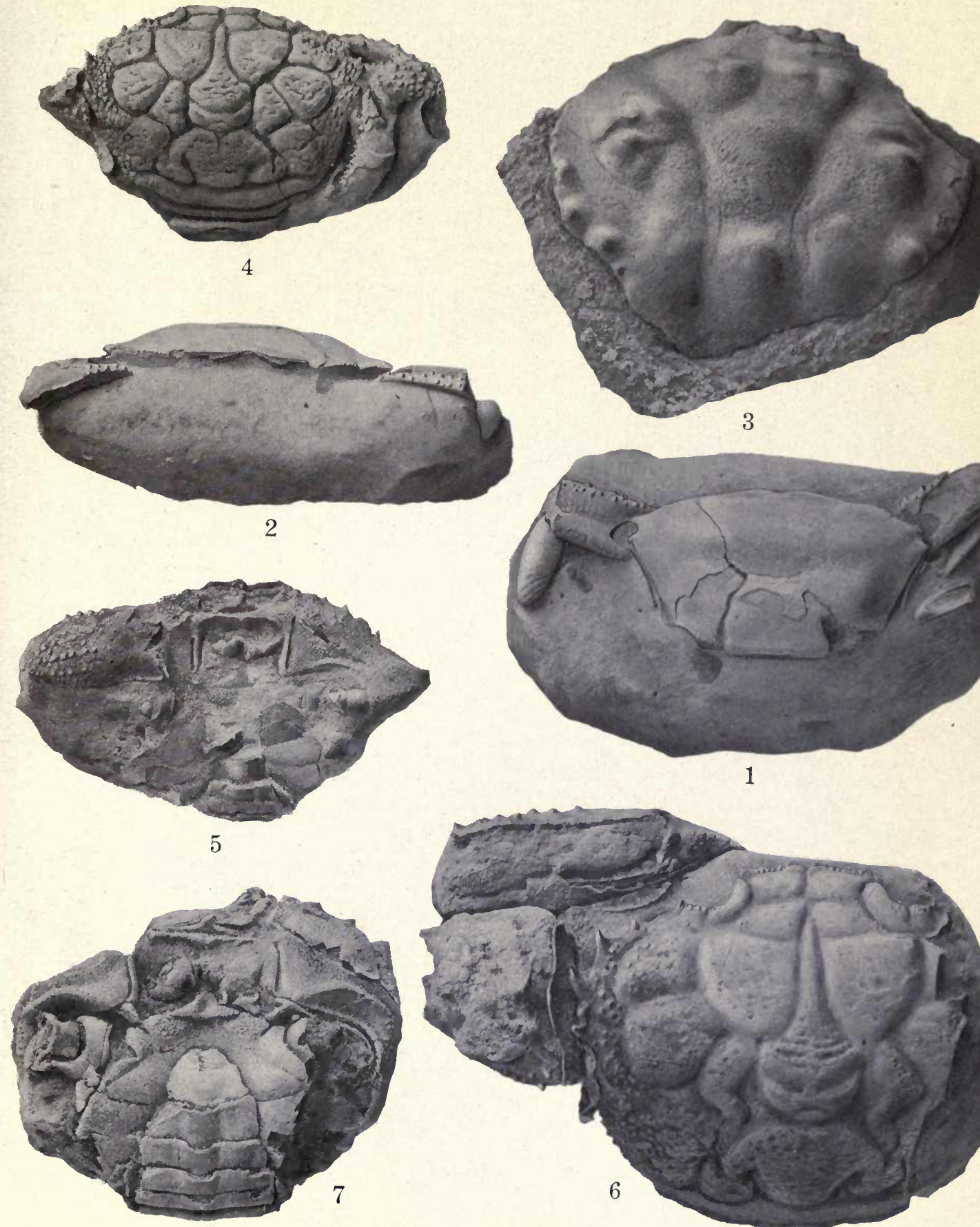

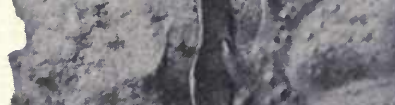

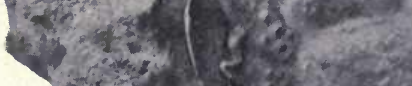

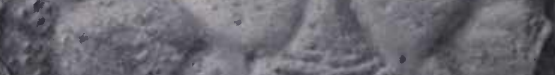
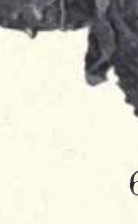



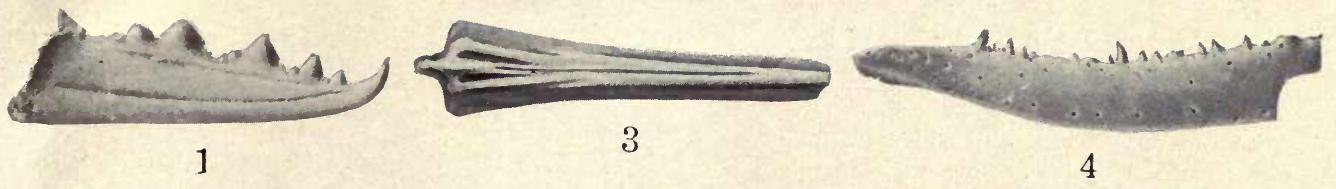

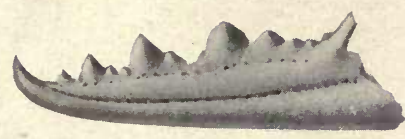

2

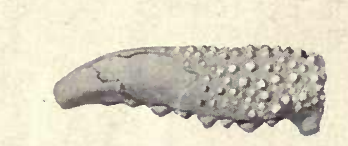

6
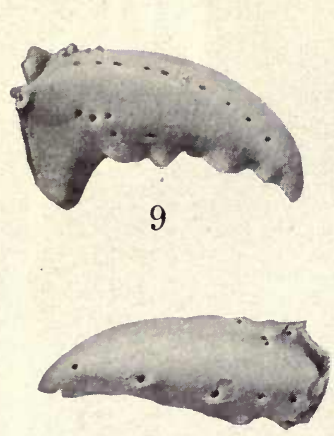

10

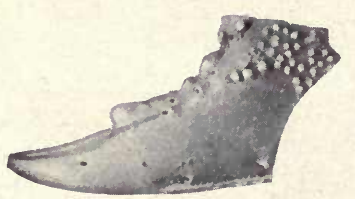

11

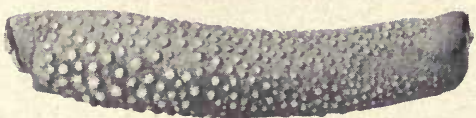

5

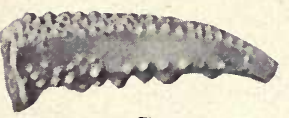

7

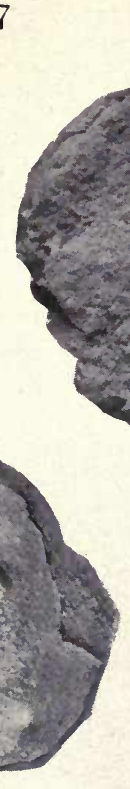

12

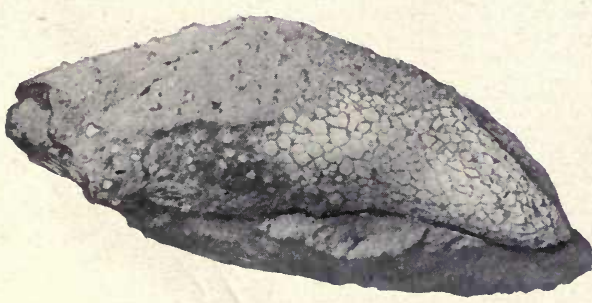

13
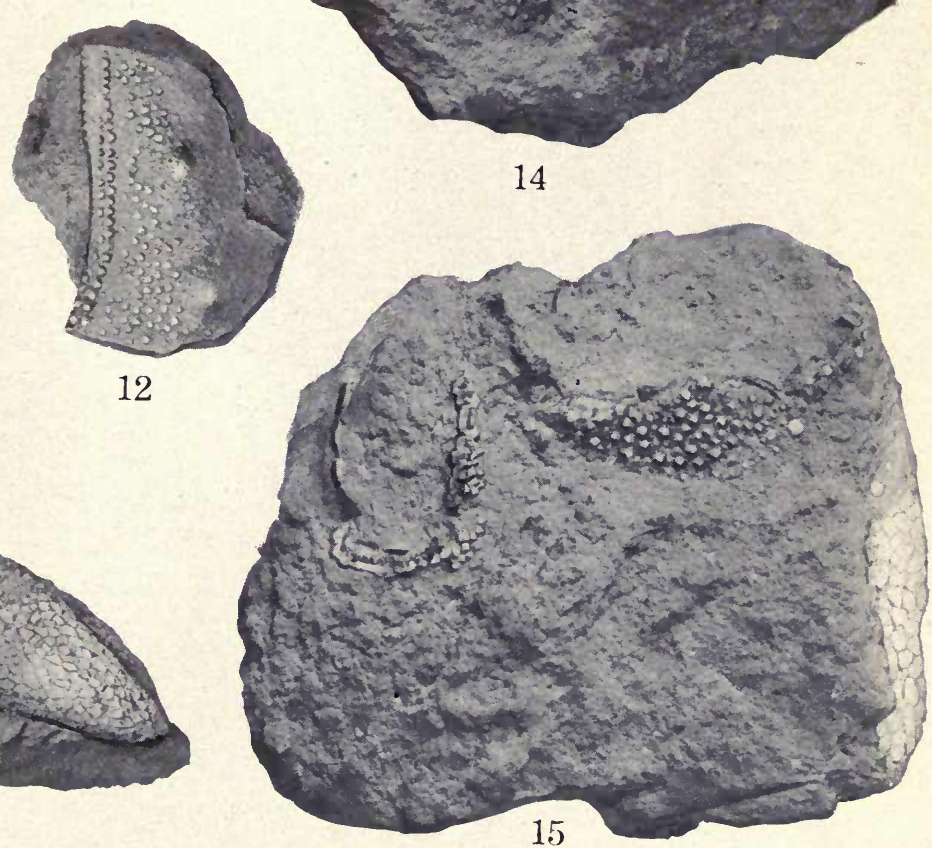


\section{DAY USE RETLEATPP PESK FROM WHICH BORROWED \\ TEL: 642-2997.}

This book is due on the last date stamped below, or on the date to which renewed.

Renewed books are subject to immediate recall.

)

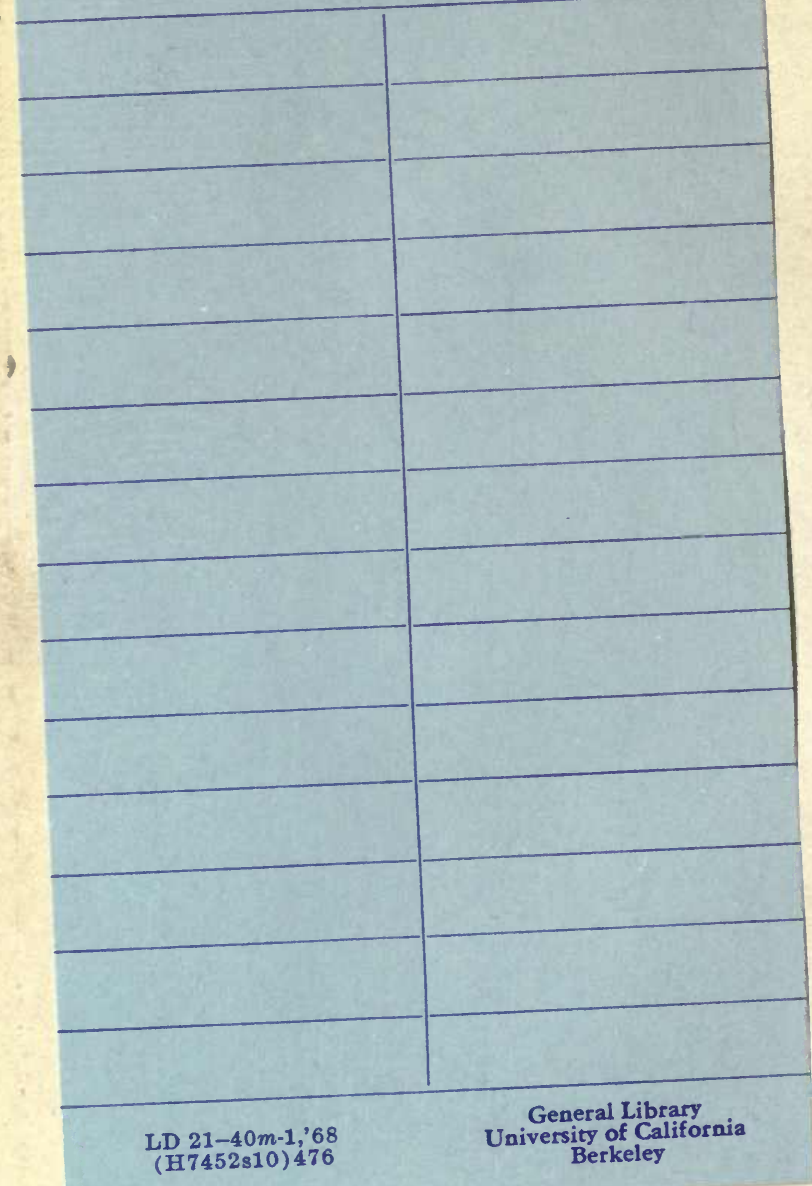





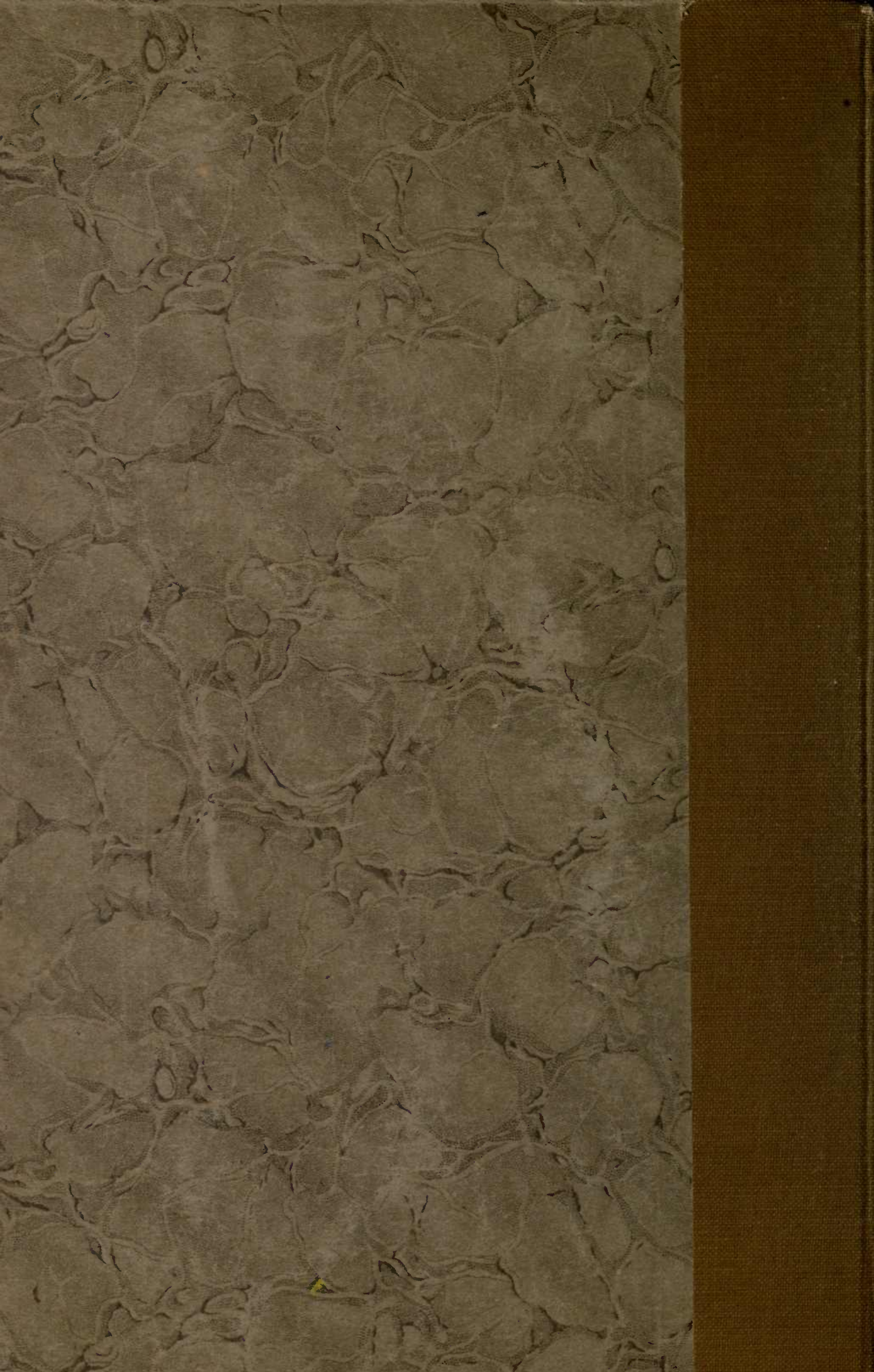

